\author{
UNIVERSIDADE DE SÃO PAULO \\ INSTITUTO DE ENERGIA E AMBIENTE \\ PROGRAMA DE PÓS-GRADUAÇÃ̃ EM ENERGIA
}

DANILO PERECIN

COMPARAÇÃO ENTRE AS ESTRATÉGIAS DE APROVEITAMENTO

ENERGÉTICO DO BIOGÁS: GERAÇÃO DE ENERGIA ELÉTRICA VERSUS PRODUÇÃO DE BIOMETANO 


\section{DANILO PERECIN}

COMPARAÇÃO ENTRE AS ESTRATÉGIAS DE APROVEITAMENTO ENERGÉTICO DO BIOGÁS: GERAÇÃO DE ENERGIA ELÉTRICA VERSUS PRODUÇÃO DE BIOMETANO

Dissertação apresentada ao Programa de PósGraduação em Energia do Instituto de Energia e Ambiente da Universidade de São Paulo para a obtenção do título de Mestre em Ciências.

Orientador: Prof ${ }^{a}$. Dr ${ }^{a}$. Suani Teixeira Coelho

Versão Corrigida 
AUTORIZO A REPRODUÇÃO E DIVULGAÇÃO TOTAL OU PARCIAL DESTE TRABALHO, POR QUALQUER MEIO CONVENCIONAL OU ELETRÔNICO, PARA FINS DE ESTUDO E PESQUISA, DESDE QUE CITADA A FONTE.

\section{FICHA CATALOGRÁFICA}

Perecin, Danilo.

Comparação entre as estratégias de aproveitamento energético do biogás: geração de energia elétrica versus produção de biometano / Danilo Perecin; orientadora: Suani Teixeira Coelho. -- São Paulo, 2017.

164 f.: il. $30 \mathrm{~cm}$.

Dissertação (Mestrado em Ciências) - Programa de Pós-Graduação em Energia - Instituto de Energia e Ambiente da Universidade de São Paulo

1. Biogás. 2. Biometano. 3. Política energética. 4. Planejamento energético.5. Recursos energéticos. I. Título. 
Nome: PERECIN, Danilo

Título: Comparação entre as estratégias de aproveitamento energético do biogás: geração de energia elétrica versus produção de biometano

Dissertação apresentada ao Programa de PósGraduação em Energia do Instituto de Energia e Ambiente da universidade de São Paulo para obtenção do título de Mestre em Ciências.

Aprovado em:

Banca Examinadora

Prof. Dr.

Instituição:

Julgamento:

Assinatura:

Prof. Dr.

Instituição:

Julgamento:

Assinatura:

Prof. Dr.

Instituição:

Julgamento:

Assinatura:

Prof. Dr.

Instituição:

Presidente

Assinatura: 


\section{AGRADECIMENTOS}

Ao meu pai e à minha mãe, pelos exemplos que são, e por continuarem a proporcionar oportunidades como essa a mim.

À Mariana, por estar do meu lado sempre. E por fazer minha vida feliz assim.

Ao Caio, por ser irmão de sangue e de ideias.

À minha orientadora Suani, por dividir seu conhecimento de forma simples. E aos colegas do GBio e do IEE, pelo suporte e amizade.

Aos Professores Carla Cavaliero, André Simões e Jorge de Lucas Junior, pela atenção dedicada ao meu trabalho.

A todos que citei, li e ouvi. Com os quais, enfim, pude aprender, essa que é das melhores sensações que se pode ter. 


\section{RESUMO}

PERECIN, D. Comparação entre as estratégias de aproveitamento energético do biogás: geração de energia elétrica versus produção de biometano. 2017. 164 f. Dissertação (Mestrado em Ciências) - Programa de Pós-Graduação em Energia da Universidade de São Paulo, São Paulo, 2017.

Os sistemas de produção e utilização do biogás podem envolver externalidades positivas como o tratamento de resíduos, a produção de biofertilizante e a redução de emissões de gases de efeito estufa. Além disso, possibilitam o desenvolvimento do potencial energético desta fonte renovável, que pode ser aproveitada por meio da geração de energia elétrica ou pela produção de biometano, combustível obtido pela purificação do biogás, e que é similar ao gás natural. Nesse contexto, o objetivo desta dissertação é detalhar estas estratégias e compará-las para o caso brasileiro. Busca-se identificar o uso mais desejável do biogás no contexto do setor energético nacional, considerando as características da fonte e sua relação com a situação atual e as perspectivas dos mercados de eletricidade e gás. Para isso, inicialmente é realizada uma revisão das tecnologias de aproveitamento do biogás e são discutidas as vantagens de se identificar um uso que possa se tornar prioritário, capaz de reunir em si os incentivos para a expansão dessa fonte na matriz energética. Argumenta-se que o desenvolvimento de uma indústria local e de projetos bem-sucedidos, necessários ao fortalecimento do biogás no Brasil, podem ser alcançados por meio da criação de mecanismos de fomento específicos para uma estratégia, que sejam claros e de longo prazo. Em seguida, a evolução desse setor na Alemanha e na Suécia é avaliada, observando-se que políticas de direcionamento da utilização do biogás conduziram o mercado, tendo como consequência sistemas voltados, respectivamente, à geração de energia elétrica e à produção de biometano para uso veicular. Baseada na definição de "política energética", a comparação entre a produção de eletricidade e de biometano a partir do biogás no Brasil é apresentada segundo os critérios: segurança no abastecimento, preço da energia, balança entre importações e exportações, infraestrutura, e aspectos ambientais. As conclusões apontam para o biometano como um uso promissor da energia do biogás no país em termos da redução de importações e em projetos de grande escala próximos à infraestrutura de gás natural, mas com barreiras a serem superadas principalmente quanto a competitividade em plantas menores e distantes dos gasodutos. A produção de energia elétrica, por outro lado, tem incentivos e mecanismos de comercialização estabelecidos e pode ser competitiva principalmente se exploradas suas características de energia firme e flexibilidade, mesmo em um contexto de concorrentes renováveis de grande potencial e em crescimento.

Palavras-chave: Biogás. Biometano. Política energética. Planejamento energético. 


\begin{abstract}
PERECIN, D. Comparing strategies of biogas energy use: electricity generation versus biomethane production. 2017. $164 \mathrm{f}$. Master's Dissertation - Graduate Program on Energy, University of São Paulo, São Paulo, 2017.
\end{abstract}

Biogas production systems may involve positive externalities such as waste treatment, biofertilizer production and the reduction of greenhouse gases emissions. Besides, they enable the use of its renewable energy potential, which can generate electricity or produce biomethane. Biomethane is obtained from biogas upgrading and it is similar to natural gas. This study details these strategies and compare them for the Brazilian case, with the aim of identifying if there is one optimal solution for biogas utilization within the context of the national energy sector, by analyzing the characteristics of biogas and its correlation with the status and the perspectives of the electricity and gas markets in the country. First, the advantages of selecting one alternative of biogas utilization to be the focus of policy instruments and to guide the development of the biogas sector are discussed. It is argued that the development of a local industry and successful projects, required to expand the biogas sector in Brazil, could benefit from technology-specific incentives, designed as clear and long-term mechanisms. The evolution of biogas systems in Germany and Sweden are investigated, and it is observed that the policies implemented in these countries have guided biogas utilization, respectively, to electricity generation and to biomethane use as vehicle fuel. Then, based on the definition of "energy policy", five criteria are selected to evaluate and compare electricity and biomethane production from biogas in Brazil: security of supply, energy price, balance of trade, infrastructure, and environmental aspects. It can be concluded that, although biomethane can have a positive impact reducing natural gas imports especially in large-scale projects close to pipeline infrastructure, it also has many barriers to overcome, including its adaptation to smallscale units and the limitation of infrastructure. Electricity generation is a more established alternative that can be feasible if its capacity to provide baseload and flexibility are properly evaluated, even facing the competition of other renewable technologies with low-cost and large potential in the country.

Keywords: Biogas. Biomethane. Energy policy. Energy planning. 


\section{LISTA DE FIGURAS}

Figura 1. Emissões de $\mathrm{CO}_{2}$ antropogênicas globais anuais desde o século XIX ....................29

Figura 2. Oferta interna de energia por fonte no Brasil em 2015 ......................................... 30

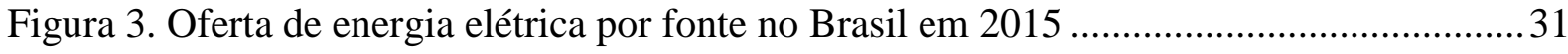

Figura 4. Capacidade instalada de geração elétrica por fonte no país, em GW, em junho de 2017 32

Figura 5. Acréscimo anual previsto de potência instalada por tipo de fonte no Brasil, de 2015 a 2024

Figura 6. Consumo anual de gás natural no Brasil, por setor, de 2006 a 2015

Figura 7. Participação, em termos de energia, dos combustíveis no setor de transporte rodoviário do Brasil, em 2015

Figura 8. Consumo e participação do GN no setor de transportes rodoviário no Brasil, de 2006 a 2015 37

Figura 9. Diagrama com as técnicas de remoção de $\mathrm{H}_{2} \mathrm{~S}$ 48

Figura 10. Exemplo da estrutura de um siloxano linear

Figura 11. Número de plantas por tecnologia de enriquecimento nos países membros da IEA

Bioenergy Task 37.

Figura 12. Custos da produção de biometano a partir da vinhaça, dividido em upgrading e produção do biogás 61

Figura 13. Custos específicos de upgrading do biogás, em dólares por $\mathrm{m}^{3}$ de metano 62

Figura 14. Uso do biogás nos países com a maior produção em 2013

Figura 15. Participação das fontes e produção total de biogás em países selecionados da Europa, em 2013.

Figura 16. Participação das formas de utilização do biogás em países selecionados da Europa

Figura 17. Produção de biometano e participação de seu uso como combustível veicular nos principais países produtores em 2013

Figura 18. Evolução do número de plantas e da capacidade de geração elétrica usando biogás no setor agrícola da Alemanha, de 2003 a 2016

Figura 19. Geração anual de eletricidade por tipo de fonte na Alemanha, de 1998 a 2014 ..... 91 Figura 20. Participação do carvão, petróleo, e gás natural na geração de energia elétrica por fontes fósseis na Alemanha, de 1998 a 2014 
Figura 21. Geração anual de eletricidade por fontes renováveis na Alemanha, de 1998 a 2014

Figura 22. Evolução da produção de biogás por substrato na Suécia, de 2005 a 2015 ............ 95

Figura 23. Evolução dos usos de biogás na Suécia, de 2005 a 2015 ....................................... 96

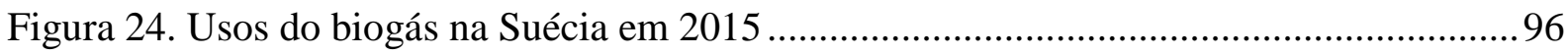

Figura 25. Participação do biometano e do gás natural no gás veicular da Suécia, de 2000 a

2014

Figura 26. Geração anual de eletricidade por tipo de fonte na Suécia, de 1998 a 2014 ........... 99

Figura 27. Geração anual de eletricidade por fontes renováveis na Suécia, de 1998 a 2014.100

Figura 28. Trilema considerado na estratégia de expansão do setor elétrico brasileiro .......... 106

Figura 29. Custos para a produção de biogás para diferentes matérias-primas e escalas de produção, em dólares (US\$) por $\mathrm{m}^{3}$ de metano .................................................................. 113

Figura 30. Custo de investimento em motogeradores para diferentes faixas de potência...... 115

Figura 31. Composição dos custos de geração para diferentes fontes.................................... 117

Figura 32. Custos para o fornecimento de biometano, em dólares (US\$) por metro cúbico, para diferentes matérias-primas e escalas de produção

Figura 33. Impacto da escala no custo específico do biometano produzido do biogás de vinhaça.

Figura 34. Comparativo de preços entre gás natural residencial, GLP, GNV e gasolina em São Paulo, em fevereiro de 2017.

Figura 35. Importações líquidas para os principais energéticos no Brasil em 2015, em termos de energia.

Figura 36. Importações líquidas de gás natural, óleo diesel, eletricidade, GLP e gasolina, de 2006 a 2015.

Figura 37. Importação de gás natural e geração de energia elétrica por gás natural, de 2010 a 2016, no Brasil, em milhões de $\mathrm{m}^{3}$ por dia.

Figura 38. Esquema da infraestrutura de transmissão de energia elétrica no Sistema

Interligado Nacional (SIN).

Figura 39. Diagrama esquemático da infraestrutura de gasodutos de transporte no Brasil.... 128 Figura 40. Infraestrutura de gás natural, incluindo gasodutos de distribuição, em área abrangendo as capitais das regiões Sul e Sudeste do Brasil

Figura 41. Evolução das malhas de transporte e distribuição de gás natural no Brasil, de 1999 a 2016

Figura 42. Comparação da malha de gasodutos de transporte entre diversos países 


\section{LISTA DE TABELAS}

Tabela 1 - Comparação entre composições médias do biogás encontradas na literatura.

Tabela 2 - Comparação entre as especificações mais rigorosas do biometano e do gás natural no Brasil..... 54

Tabela 3 - Comparação entre as principais técnicas de enriquecimento do biogás. 60

Tabela 4 - Resumo das opções de utilização do biogás avaliadas 64

Tabela 5 - Identificação dos focos das análises realizadas nos trabalhos da revisão bibliográfica sobre energia elétrica versus biometano

Tabela 6 - Resumo das características dos períodos do biogás do setor agrícola na Alemanha

Tabela 7 - Número de plantas, geração de eletricidade e de calor por tipo de substrato na produção de biogás na Alemanha, em 2014 e 2015. 86

Tabela 8 - Aproveitamento energético do biogás por uso final, na Alemanha, em 2015 87

Tabela 9 - Restrições para obtenção de bônus tecnológico para plantas de produção de biometano nas leis alemãs EEG 2009 e 2012

Tabela 10 - Custo específico de instalação de equipamentos de geração de energia elétrica 114

Tabela 11 - Estimativas de custo de geração de energia elétrica com biogás 116

Tabela 12 - Extensão, em km, das linhas de transmissão do Sistema Interligado Nacional (SIN) com tensão maior ou igual a $230 \mathrm{kV}$

Tabela 13 - Fatores de emissão de GEE por tecnologia de geração no Brasil

Tabela 14 - Objetivos do PNPB identificados em relação ao uso do biogás 


\section{LISTA DE SIGLAS}

ABiogás

ANEEL

ANP

ARSESP

CCEE

CHP

EEG

EPE

ETE

EUA

GEE

GLP

GNL

GNV

GWP

IEA

IPCC

MME

ONS

PCS

PNBB

PNRS

ppm

Probiogás

PSA

RSU

SIN

UE
Associação Brasileira de Biogás e Biometano

Agência Nacional de Energia Elétrica

Agência Nacional de Petróleo, Gás Natural e Biocombustíveis

Agência Reguladora de Saneamento e Energia do Estado de São Paulo

Câmara de Comercialização de Energia Elétrica

Combined Heat and Power

Erneuerbare-Energien-Gesetz (Lei das Fontes Renováveis de Energia da Alemanha)

Empresa de Pesquisa Energética

Estação de Tratamento de Esgoto

Estados Unidos da América

Gases de Efeito Estufa

Gás Liquefeito de Petróleo

Gás Natural Liquefeito

Gás Natural Veicular

Global Warming Potential

International Energy Agency

Intergovernmental Panel on Climate Change

Ministério de Minas e Energia

Operador Nacional do Sistema Elétrico

Poder calorífico superior

Proposta de Plano Nacional do Biogás e do Biometano

Política Nacional de Resíduos Sólidos

partes por milhão

Projeto Brasil-Alemanha de Fomento ao Aproveitamento Energético de Biogás no Brasil

Pressure Swing Adsorption

Resíduos Sólidos Urbanos

Sistema Interligado Nacional

União Europeia 


\section{SUMÁRIO}

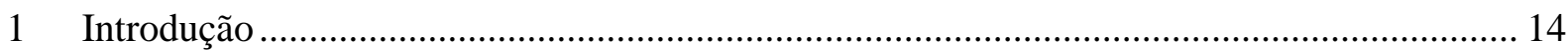

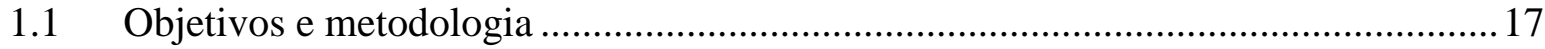

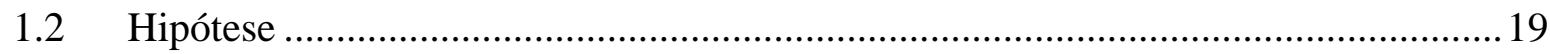

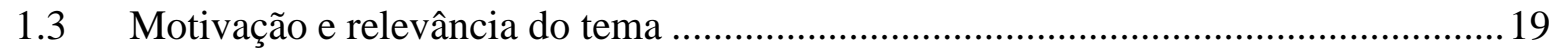

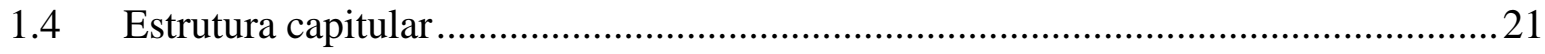

2 Biogás, sustentabilidade ambiental e o setor energético...................................................... 22

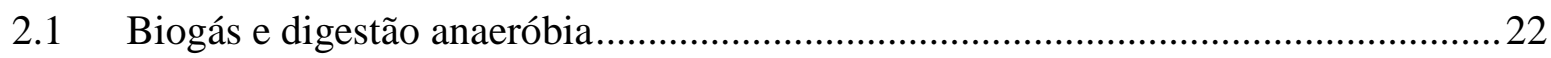

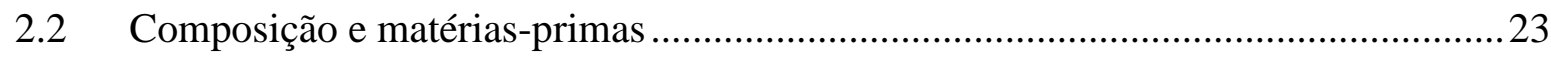

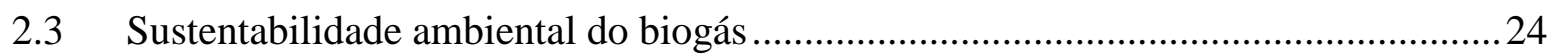

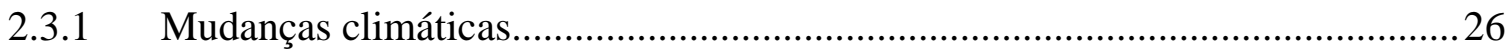

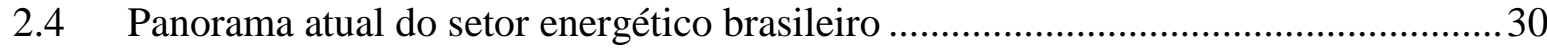

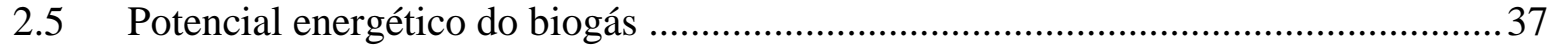

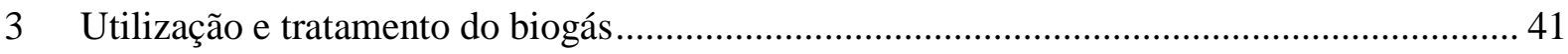

3.1 Queima sem aproveitamento energético ........................................................ 41

3.2 Aproveitamento energético do biogás ................................................................ 42

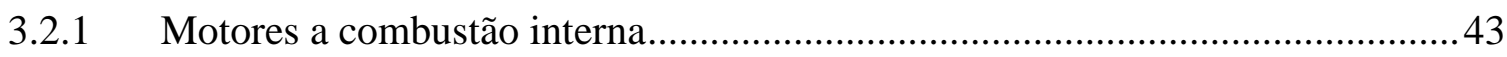

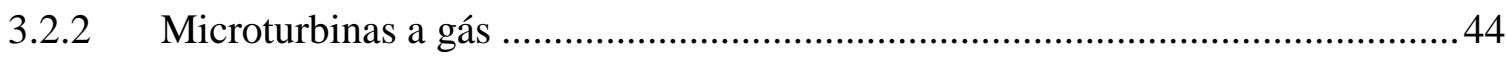

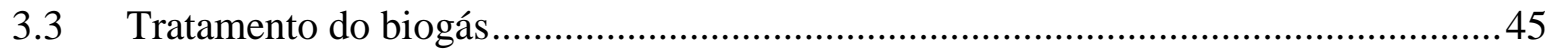

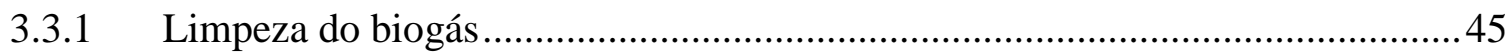

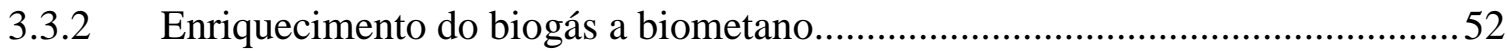

4 Direcionamento da utilização e experiência internacional ...................................................... 64

4.1 Energia Elétrica x Biometano - revisão bibliográfica ............................................. 65

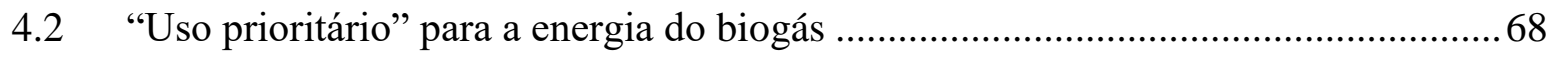

4.3 Escolha pelo mercado versus intervenção do Estado ........................................... 72

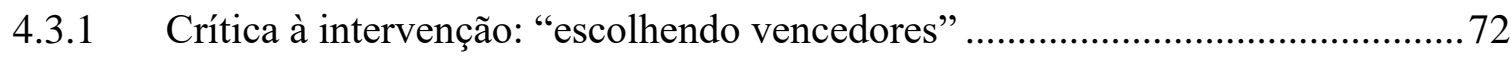

4.3.2 Neutralidade tecnológica e defesa do apoio direcionado ................................ 73 


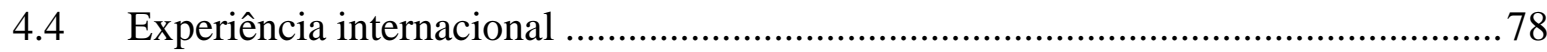

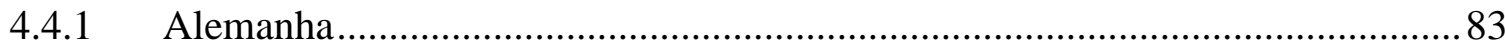

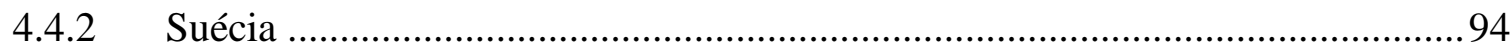

5 Comparação entre energia elétrica e biometano para o Brasil............................................ 102

5.1 Identificação dos critérios para comparação..................................................... 103

5.2 Uso dos critérios e forma de comparação .......................................................... 107

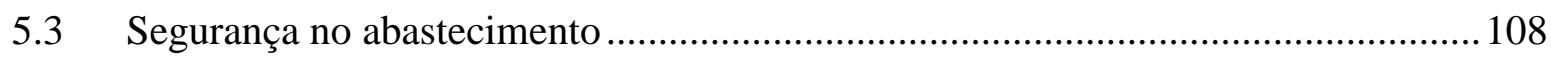

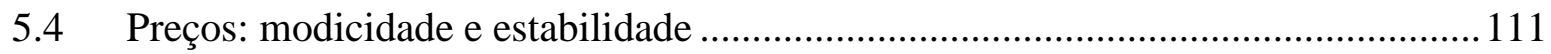

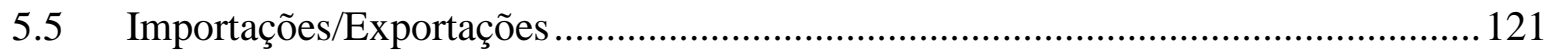

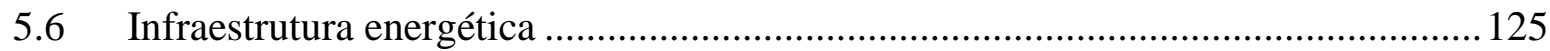

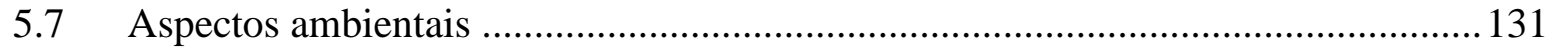

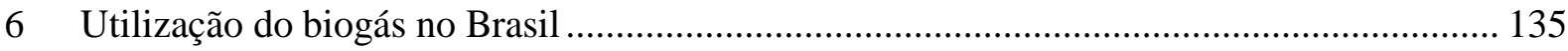

6.1 Políticas, propostas e experiência brasileira ..................................................... 135

6.1.1 Regulação e incentivos para geração de energia elétrica ................................. 136

6.1.2 Regulação e incentivos para produção de biometano...................................... 138

6.2 Propostas referentes à utilização do biogás ............................................................. 142

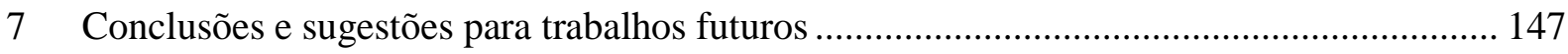

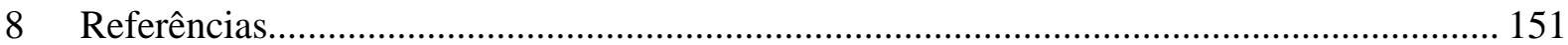




\section{INTRODUÇÃO}

O tratamento de resíduos de matéria orgânica pela digestão anaeróbia tem diversos benefícios ambientais. Entre eles, a promoção do saneamento e a redução de volume dos resíduos, a redução de emissões de metano na atmosfera, e a possibilidade de produção de biofertilizante e do biogás, um biocombustível renovável. $\mathrm{O}$ aproveitamento energético do biogás é uma forma de viabilizar seu processo de produção e todas as suas externalidades positivas.

A composição química típica do biogás é responsável pela variedade de estratégias de utilização deste combustível. Ele é composto majoritariamente de metano $\left(\mathrm{CH}_{4}\right)$, o elemento combustível, e de dióxido de carbono $\left(\mathrm{CO}_{2}\right)$, inerte, além de impurezas presentes em menor quantidade, como o sulfeto de hidrogênio $\left(\mathrm{H}_{2} \mathrm{~S}\right)$, corrosivo, que deve ser removido para um aproveitamento energético eficiente. Pelo elevado teor de metano, deve-se evitar o descarte de biogás na atmosfera, devido ao potencial de aquecimento global do $\mathrm{CH}_{4}$ ser 28 vezes maior que o do $\mathrm{CO}_{2}$ para um horizonte de 100 anos (IPCC, 2013).

A opção mais simples para destinação do biogás é sua queima sem aproveitamento energético, com a intenção apenas de transformar o metano em dióxido de carbono, para reduzir emissões de gases de efeito estufa.

A primeira opção para o aproveitamento energético do biogás é a geração de calor, para atender uma demanda térmica próxima à produção. Essa demanda local pode ser menor que a energia contida no biogás gerado, ou não existir, especialmente em um país tropical como o Brasil. Nesses casos, há excedente para ser ofertado a outros consumidores. Duas formas podem tornar a energia do biogás disponível de forma comercializável: a geração de energia elétrica e a produção do biometano.

Há, ainda, outras opções em estágio inicial de desenvolvimento tecnológico - e que por este motivo não serão avaliadas neste estudo -, como a produção de gás de síntese/hidrogênio ou de metanol a partir do metano (YANG et al., 2014).

Entre as duas opções comercializáveis, a geração de energia elétrica é a alternativa de utilização do biogás consolidada há mais tempo. Em 2006, Costa, D. (2006) reportava projetos em operação comercial e em instalação no Brasil, como os aterros Bandeirantes e São João, em São Paulo, e analisava que a experiência brasileira crescia gradualmente naquela ocasião; no 
mesmo ano, a Alemanha, por exemplo, somava 3.500 plantas de geração de energia elétrica no setor agrícola (FNR, 2013).

A outra opção é a produção de biometano, um "biocombustível gasoso constituído essencialmente de metano, derivado da purificação do biogás" (ANP, 2015). Ele é produzido por um processo de tratamento do biogás, que consiste na remoção de outros componentes, para atingir os requerimentos de pureza em metano.

O biometano é similar ao gás natural, combustível fóssil responsável por $21,2 \%$ do consumo mundial de energia em 2014 (IEA, 2016). Para que possa ser misturado ao gás natural ou comercializado como tal, a qualidade do biometano deve atender a regulação específica da Agência Nacional de Petróleo, Gás Natural e Biocombustíveis (ANP) - no Brasil, a pureza em metano é de no mínimo 96,5\% (ANP, 2015). A origem renovável do biometano o diferencia do gás natural, que é composto majoritariamente da mesma molécula - o metano -, mas possui também outros hidrocarbonetos leves na composição, como será analisado na Seção 3.

Diversos trabalhos vêm sendo publicados recentemente avaliando as tecnologias de tratamento do biogás (PATTERSON et al., 2011; SUN et al., 2015; KADAM; PANWAR, 2017) e as perspectivas do biometano, inclusive no Brasil (VEIGA, 2016), especialmente para utilização como combustível veicular (PROBIOGÁS, 2016b; IRENA, 2017). O uso no setor de transportes chama atenção por este ser limitado em alternativas renováveis, se comparado ao setor de geração de energia elétrica (LARSSON; GRONKVIST; ALVFORS, 2016).

Recentemente, segundo Veiga (2016), criou-se no país expectativas otimistas sobre o desenvolvimento do biometano, baseadas em experiências internacionais bem-sucedidas. Entre elas, o crescimento do número de plantas de produção de biometano na Alemanha a partir da primeira, que entrou em operação em 2006, e o progresso da Suécia no uso como combustível veicular. Na prática, o desenvolvimento do biometano no Brasil tem sido marcado por avanços ainda tímidos, tanto no aspecto comercial, com a entrada em operação de poucos projetos, como na regulação - apenas em 2015 foi publicada a resolução que especificou a qualidade desse combustível, ainda limitando as fontes de biogás permitidas (ANP, 2015).

A geração de energia elétrica e a produção de biometano são alternativas que diferem entre si em vários aspectos: na tecnologia dos processos, nos produtos resultantes, nos mercados para comercialização e suas regulamentações, nas fontes que substituem ou complementam, na infraestrutura necessária, entre outros. Consequentemente, é possível que exista uma destas duas opções que resulte em mais benefícios para o setor energético e para a sociedade e, 
portanto, possa ser estimulado de forma mais intensa pelos formuladores de políticas - ou seja, um "uso prioritário". A adoção de um uso prioritário é uma das propostas deste trabalho, que será avaliada em maior profundidade na Seção 4.

A estratégia de um uso prioritário pode ter outras consequências. Em relatório visando a identificar as barreiras para o desenvolvimento do setor de biogás no Brasil, Probiogás (2016) encontrou ${ }^{1}$, entre outras:

- Inexistência de políticas específicas relacionadas ao biogás, que não tem a importância estratégica reconhecida em sua amplitude;

- A falta de "projetos de referência bem-sucedidos em escala comercial", que possam reduzir incertezas para os empreendedores;

- A "dificuldade no acesso a informações técnicas, comerciais e legais", como a "diversidade de arranjos comerciais possíveis, inserida em uma variedade de mercados e culturas de negócios";

- Custos elevados de investimento e operação, resultantes, por exemplo, de volume de mercado reduzido e opções limitadas de fornecedores nacionais.

O foco do setor de biogás, ao menos na tecnologia de utilização e no mercado em que sua energia se insere ${ }^{2}$, pode contribuir com a solução dessas quatro questões. Ou seja, uma política específica poderia ser criada incentivando uma alternativa de utilização, gerando experiência em projetos com arranjos tecnológicos e comerciais determinados, reduzindo a percepção de riscos e criando um mercado relacionado à alternativa incentivada.

Sem política de direcionamento, o desenvolvimento de cada alternativa pode sofrer com a concorrência entre elas, dificultando a cada uma o avanço na curva de aprendizado, a criação de uma indústria própria, e a redução de custos. Além disso, ambas competem por um potencial energético limitado, ainda mais se considerado apenas o economicamente viável.

Pelo lado regulatório, a participação dividida do biogás entre as alternativas de utilização e os diferentes mercados também pode ser uma barreira para a formulação de medidas voltadas à participação do combustível na matriz energética, por atrapalhar a percepção do potencial dessa participação pelos formuladores de políticas, além de impedir que um setor se "responsabilize" pelo desenvolvimento dessa fonte.

\footnotetext{
${ }^{1}$ Faz-se a ressalva de que a análise é controversa e pode não representar a opinião de todos os especialistas.

${ }^{2}$ Considera-se que os produtos resultantes do biogás, ou seja, a energia elétrica ou o biometano, são formas comercializáveis da energia do biogás. Portanto, os mercados em que a "energia” do biogás se insere, nestes casos, seriam o mercado de energia elétrica e o mercado para o biometano, semelhante ao mercado de gás natural.
} 
A escolha de um uso prioritário pode, portanto, facilitar a superação de alguns entraves do setor de biogás no Brasil. Por outro lado, há desvantagens nessa estratégia, justamente por ser uma intervenção política direcionando o mercado. É, também, intrínseca a ela certo menosprezo à flexibilidade característica da utilização do biogás, ao distorcer uma escolha que pode ter, para a condição específica de cada planta, uma opção mais adequada.

A definição de uma política que tenha como objetivo potencializar os efeitos positivos da produção de biogás e da sua participação na matriz energética brasileira deve lidar com a diversidade de alternativas de utilização. Identificar os mercados e setores que mais poderiam integrar da melhor forma a energia renovável do biogás ao setor energético pode ser uma das atividades estratégicas para desenvolver a cadeia de produção deste biocombustível no país.

Neste trabalho se buscará discutir os principais aspectos envolvidos em uma política direcionada à utilização do biogás e comparar as alternativas de utilização sob diversos critérios, especialmente sob o ponto de vista do planejamento do setor energético, buscando abrangência e imparcialidade na avaliação.

É importante fazer a ressalva de que, como esta dissertação aborda temas em constante atualização, como o desenvolvimento do setor de biogás e o contexto do setor energético, será retratada uma situação conjuntural, do momento em que este trabalho foi desenvolvido e até a efetiva publicação.

\subsection{Objetivos e metodologia}

O objetivo geral deste trabalho é comparar, em termos de política energética para o Brasil, o uso do biogás para geração de energia elétrica com o seu uso para a produção de biometano. Portanto, os critérios para comparação serão os principais aspectos que envolvem uma política energética.

Essa comparação busca, sob o ponto de vista do planejamento do setor energético, identificar os benefícios e as desvantagens de cada estratégia de utilização do biogás, podendo contribuir com os fundamentos para uma possível política de incentivos com direcionamento com relação à utilização. Portanto, será realizada uma análise abrangente, capaz de identificar características relevantes às duas estratégias de aproveitamento do biogás e sua relação com o contexto do setor energético do país. 
A determinação dos critérios que serão avaliados é baseada nas definições de "política energética" e nas experiências de política energética da União Europeia, Estados Unidos e Brasil, a serem apresentadas em detalhes na Seção 5.1. Os critérios avaliados serão:
i. Diversificação de fontes;
ii. Preços da energia;
iii. Balança de importações e exportações;
iv. Infraestrutura energética;
v. Aspectos ambientais.

Como conclusão, um parecer sobre a análise será apresentado. No entanto, ressalta-se a impossibilidade de discutir todas as questões, as controvérsias sobre a importância de cada uma, e a dificuldade de se hierarquizar os critérios avaliados, resultante do fato de uma intervenção política ser "fortemente marcada por concepções e visões de mundo" como analisa Pinto Jr. et al. (2007). Portanto, a conclusão não terá a pretensão de ser definitiva ou de apontar um caminho único, mas de contribuir com a discussão do tema.

Assim, a proposta é usar o estudo para mostrar dados relevantes e aspectos teóricos para subsidiar a comparação e contribuir com possíveis decisões de políticas. A conclusão deve apresentar as impressões derivadas das análises realizadas.

O trabalho também será composto da construção de uma base para o objetivo principal, se estendendo a discussões relevantes que envolvem as alternativas de utilização do biogás e a escolha por um direcionamento do setor. Define-se, portanto, os objetivos específicos:

- Revisar as tecnologias das opções de utilização, limpeza e enriquecimento do biogás em seu estado-da-arte, garantindo a premissa de que questões dessa ordem não inviabilizam qualquer das estratégias de utilização e, portanto, a comparação pretendida no objetivo geral;

- Identificar as vantagens e desvantagens da adoção de um "uso prioritário" a ser incentivado pelas políticas públicas;

- Revisar a experiência internacional em relação à utilização do biogás e identificar a influência das políticas;

- Aplicar a definição e experiências de "política energética" para identificar os aspectos mais relevantes que a envolvem; 
- Utilizar os critérios para identificar as vantagens e desvantagens de cada forma de aproveitamento do biogás, confrontando suas características com as oportunidades e o contexto do mercado em que se inserem, de acordo com o objetivo geral;

- Analisar criticamente experiências de políticas e legislações vigentes aplicáveis ou relacionadas à utilização do biogás, propostas de agentes do setor e da academia.

\subsection{Hipótese}

Em avaliação preliminar, notou-se que o setor elétrico brasileiro possui uma matriz renovável, cuja expansão deve se dar da mesma maneira devido à diversidade de alternativas competitivas com grande potencial energético, como as fontes hidráulica, eólica, solar e biomassa. Por sua vez, o biometano se apresenta como complemento ao gás natural, capaz de ser aproveitado em diferentes usos finais atualmente dominados por fontes fósseis. Dessa forma, a hipótese inicial, a ser avaliada pela pesquisa, é que a produção de biometano pode ser uma opção com mais oportunidades no planejamento do setor energético brasileiro - comparada à geração de energia elétrica com biogás -, podendo assim ser incentivado por políticas direcionadas.

A própria sugestão de adoção de um uso prioritário, ou seja, de que um uso deve ser preferencialmente incentivado, pode ser identificada como uma hipótese a ser avaliada no trabalho; de acordo com o descrito na Seção 1.1, não é o objetivo principal, mas as vantagens identificadas inicialmente por este autor e que levaram a essa proposta, e as principais desvantagens de uma estratégia nesse sentido, serão discutidas e fazem parte dos objetivos específicos.

\subsection{Motivação e relevância do tema}

A escolha de uma estratégia que integre, da maneira mais eficaz, o biogás na matriz energética brasileira pode ter diversas consequências positivas: compor uma estratégia sustentável, renovável e segura para o atendimento à demanda de energia; contribuir com a promoção do uso racional dos recursos, como os hídricos e os combustíveis fósseis, e da terra agricultável do país; contribuir para viabilizar cada vez mais empreendimentos para o tratamento de resíduos, com seus benefícios em saúde pública, saneamento e redução na 
emissão de gases de efeito estufa; efeitos econômicos positivos, como a melhoria de indicadores como geração de empregos e produção nacional.

É possível, ainda, que o trabalho de um setor, seja o de energia elétrica ou o de gás natural, dedicado e focado em prol do desenvolvimento do biogás, possa trazer melhores resultados do que a divisão de responsabilidade entre os dois setores; nota-se, no entanto, que, em ambos pode haver espaço, respeitando a viabilidade caso-a-caso, e deve-se buscar eliminar qualquer barreira que impeça o desenvolvimento em qualquer setor.

O trabalho em si busca comparar os usos atualmente possíveis de serem comercializados do biogás, visando a encontrar o mercado no qual ele melhor se encaixa e tem perspectivas de se tornar relevante, podendo ser estimulado de forma direcionada. A política energética, com sua abrangência sobre incentivos, subsídios, isenção de impostos sobre produtos, equipamentos e matérias-primas, promoção de leilões, entre outras medidas, é decisiva para o sucesso de uma estratégia e de um produto no mercado. O biogás, com suas externalidades positivas não contabilizadas economicamente e seu status ainda incipiente, longe de seu potencial, necessita do apoio que as instituições responsáveis pela política energética possam fornecer; portanto, seu desenvolvimento depende do entendimento do planejamento e da política em relação ao setor.

O objetivo do trabalho, com a análise em termos de política energética, está diretamente relacionado com a idealização do Programa de Pós-Graduação em Energia do Instituto de Energia e Ambiente da Universidade de São Paulo. A proposta de criação deste Programa foi de "desenvolver uma abordagem das questões energéticas com visão global, multidisciplinar e integrada" (IEE, 2016). A análise a que se propõe este trabalho permite o estudo de diversos aspectos do setor energético, envolvendo questões de tecnologia, de economia da energia, do mercado e regulação de energia elétrica, do mercado e regulação do biometano, entre outros.

Por fim, a urgência de ações relacionadas ao tema das mudanças climáticas e ao desenvolvimento de alternativas para o tratamento de resíduos e seu aproveitamento energético, estimulam um trabalho que pretende colaborar com soluções integradas e eficientes para garantir os investimentos necessários nessas questões sensíveis à sociedade brasileira e mundial. 


\subsection{Estrutura capitular}

Esta dissertação está dividida em seis seções. Esta Seção 1 é introdutória ao tema, apresentando os objetivos e a metodologia, a hipótese, e a motivação. A Seção 2 dá suporte teórico ao trabalho, com a apresentação da produção do biogás e das questões ligadas à sustentabilidade ambiental do processo de tratamento de resíduos pela digestão anaeróbia. Essa fundamentação é essencial pois mostra os motivos de essa fonte de energia ser renovável e sustentável e suas externalidades positivas, ou seja, os principais argumentos para que existam políticas de incentivo ao desenvolvimento de projetos no setor. Consta nesta seção uma revisão do potencial energético do biogás no país, aspecto essencial para avaliar a dimensão da contribuição que essa fonte pode ter na matriz energética.

Em seguida, aponta-se para o foco do trabalho, a utilização do biogás como fonte de energia. A Seção 3 tem como objetivo mostrar o estado-da-arte das tecnologias de aproveitamento energético, de limpeza e de enriquecimento do biogás. Essa é a base para indicar que as duas alternativas de disponibilizar o biogás de forma comercializável para o setor energético são a geração de energia elétrica e a produção de biometano.

A Seção 4 avalia diversas dimensões da proposta de se direcionar, por meio de políticas de incentivo, o uso do biogás para uma dessas alternativas. São discutidas as vantagens e desvantagens de um "uso prioritário" para o biogás, e como a experiência internacional pode contribuir nessa análise. Para isso, é estudado de que forma se desenvolveram os setores de biogás, especialmente na utilização, na Alemanha e na Suécia.

Na Seção 5, o objetivo principal do trabalho é então desenvolvido. São definidos os critérios e é realizada a comparação entre o uso de biogás para geração de energia elétrica e para a produção de biometano no Brasil, em termos de política energética. A conjuntura e o planejamento do setor energético brasileiro são avaliados para encontrar as oportunidades e barreiras para cada estratégia.

A Seção 6 avalia como a sugestão de adoção de um "uso prioritário" está contextualizada com as políticas, diagnósticos, e propostas para o setor de biogás, e quais são as características do desenvolvimento do setor de biogás na questão da utilização, para avaliar a concordância desse caminho com as visões reveladas na Seção 5.

Por fim, na Seção 7 serão apresentadas as conclusões do trabalho e sugestões para trabalhos futuros. 


\section{BIOGÁS, SUSTENTABILIDADE AMBIENTAL E O SETOR ENERGÉTICO}

\subsection{Biogás e digestão anaeróbia}

O biogás é uma mistura gasosa, constituída em sua maioria por metano e dióxido de carbono, proveniente da decomposição da matéria orgânica em meio anaeróbio, ou seja, na ausência de oxigênio. Esse processo, também chamado de fermentação anaeróbia, é realizado por microrganismos e ocorre naturalmente no meio ambiente (PROBIOGÁS, 2010).

A digestão anaeróbia é um processo bioquímico de reações sucessivas, que podem ser divididas em quatro estágios: hidrólise, acidogênese, acetogênese e metanogênese (PECORA, 2006; PROBIOGÁS, 2010).

$\mathrm{Na}$ primeira etapa, bactérias hidrolíticas liberam enzimas que decompõem compostos orgânicos complexos, como carboidratos, proteínas e lipídios, em substâncias menos complexas como açúcares, aminoácidos e ácidos graxos (PROBIOGÁS, 2010). A ação é extracelular devido ao tamanho dos compostos, que impossibilita a penetração dos mesmos nas células (PECORA, 2006).

Na acidogênese, já dentro das células, é realizada a decomposição desses compostos intermediários em ácidos graxos de cadeia curta, dióxido de carbono, amônia, e hidrogênio (PECORA, 2006). Também são formados, em menores quantidades, ácido lático e álcoois. Nesse estágio atuam bactérias fermentativas acidogênicas (PROBIOGÁS, 2010).

A acetogênese, por sua vez, corresponde à conversão dos compostos resultantes da fase anterior em ácido acético, cuja redução forma metano na fase metanogênica, além de hidrogênio e dióxido de carbono, a partir dos quais também há a produção de metano na última etapa (PECORA, 2006; PROBIOGÁS, 2010).

Quando realizado de forma controlada em um biodigestor, o processo de digestão anaeróbia da matéria orgânica tem dois produtos: o biogás, efluente gasoso, e o digestato (BLEY JR., 2015), que pode ser líquido e/ou sólido, dependendo do substrato, ou seja, da matéria-prima. No caso de aterros sanitários, a digestão do lixo ocorre sob camadas do solo que o cobriu e a captação do biogás é feita por meio de uma rede de tubos (FIGUEIREDO, 2011). 


\subsection{Composição e matérias-primas}

Como consequência das características do processo, a composição e a produção de biogás são variáveis. Alguns fatores exercem influência no resultado da digestão anaeróbia, como: a temperatura e o pH, que determinam a atividade de cada microrganismo; a disponibilidade de nutrientes, que influencia na sobrevivência e na taxa de crescimento dos microrganismos; a presença de inibidores, que podem ocasionar a parada da digestão; e parâmetros operacionais, como agitação e tempo de digestão (PROBIOGÁS, 2010).

A diversidade de tipos de biomassa também faz com que não haja apenas uma composição típica de biogás. A decomposição anaeróbia e a geração de biogás podem ser utilizados no tratamento de resíduos de matéria orgânica, como:

- resíduos agropecuários (RIBEIRO, 2013);

- esgoto e lodo de estações de tratamento de esgoto (LOBATO, 2011);

- resíduos sólidos urbanos (FIGUEIREDO, 2011) e restos de alimentos (ZHANG et al., 2014); - resíduos industriais, como de frigoríficos e laticínios (PROBIOGÁS, 2015b);

- vinhaça, resultante do processo de destilação do etanol de cana-de-açúcar (POVEDA, 2014).

Cada material orgânico, em dada condição, produz certa quantidade de biogás por unidade de massa, com concentrações diferentes de cada componente no biogás. É possível obter estimativas do rendimento potencial de geração de biogás e metano baseado nos valores típicos de proteínas, gorduras e carboidratos (PETTERSON e WELLINGER, 2009). Para isso, é necessário conhecimento prévio da composição da matéria-prima. No entanto, parte dos resíduos citados têm composições pouco previsíveis e podem variar de acordo com a região e por sazonalidades, por exemplo.

Explica-se, por todas essas características, que se apresente a composição do biogás em faixas médias de concentração para cada componente. Mesmo assim, é comum encontrar variações nos valores em diferentes trabalhos. Isso pode se justificar pela opção de cada autor, que pode focar, por exemplo, em uma matéria-prima, ou ter a intenção de mostrar maior ou menor amplitude das faixas de concentração, e ainda pela própria inconstância e variabilidade da composição. A Tabela 1 apresenta diferentes composições médias do biogás encontradas na literatura. 
Tabela 1 - Comparação entre composições médias do biogás encontradas na literatura.

\begin{tabular}{|l|l|l|l|l|l|l|l|l|l|}
\hline & Unidade & {$[1]$} & {$[2]$} & {$[3]^{*}$} & {$[4]^{* *}$} & {$[5]^{*}$} & {$[6]^{* * *}$} & {$[7]$} & {$[8]^{*}$} \\
\hline $\mathrm{CH}_{4}$ & $\%$ vol. & $50-75$ & $60-70$ & $35-65$ & $60-85$ & $45-50$ & $60-70$ & $53-70$ & $36-65$ \\
\hline $\mathrm{CO}_{2}$ & $\%$ vol. & $25-45$ & $30-40$ & $15-65$ & $5-15$ & $30-45$ & $20-40$ & $30-50$ & $25-47$ \\
\hline $\mathrm{H}_{2} \mathrm{~S}$ & ppm & $\begin{array}{l}20- \\
20000\end{array}$ & $\begin{array}{l}0- \\
4000\end{array}$ & $0-100$ & $\begin{array}{l}1000- \\
2000\end{array}$ & $10-200$ & $<1000$ & $0-2000$ & $30-500$ \\
\hline $\mathrm{H}_{2} \mathrm{O}$ & $\%$ vol. & $2-7$ & $\mathrm{NE}$ & $\mathrm{NE}$ & $\mathrm{NE}$ & $\mathrm{NE}$ & $\mathrm{NE}$ & $\mathrm{NE}$ & $\mathrm{NE}$ \\
\hline $\mathrm{N}_{2}$ & $\%$ vol. & $<2$ & $\sim 0,2$ & $5-40$ & $10-25$ & $0-15$ & $<2$ & $2-6$ & $1-17$ \\
\hline $\mathrm{O}_{2}$ & $\%$ vol. & $<2$ & 0 & $0-5$ & traços & 0,8 & 0 & $0-5$ & $1-3$ \\
\hline $\mathrm{H}_{2}$ & $\%$ vol. & $<1$ & 0 & $0-3$ & $0-3$ & traços & 0 & 0 & $0-3$ \\
\hline $\mathrm{NH}$ & $\mathrm{ppm}$ & $\mathrm{NE}$ & $\sim 100$ & $\sim 5$ & $\mathrm{NE}$ & $\mathrm{NE}$ & $\mathrm{NE}$ & $<100$ & $\mathrm{NE}$ \\
\hline $\mathrm{CO}$ & $\%$ vol. & $\mathrm{NE}$ & $\mathrm{NE}$ & $\mathrm{NE}$ & $0-0,3$ & $0-0,2$ & 0 & $\mathrm{NE}$ & $\mathrm{NE}$ \\
\hline $\begin{array}{l}\mathrm{Silo}- \\
\text { xanos }\end{array}$ & $\mu \mathrm{g} / \mathrm{g}$ & $\mathrm{NE}$ & $\mathrm{NE}$ & $\mathrm{NE}$ & $\mathrm{NE}$ & $\mathrm{NE}$ & $\mathrm{NE}$ & $0,08-$ & $0,3-36$ \\
\hline
\end{tabular}

*biogás de aterro sanitário; **biogás de esgoto doméstico; ***biogás de digestores de lodo;

NE: não especificado.

Fontes: [1]: Probiogás (2010); [2] e [3]: Petterson e Wellinger (2009); [4], [5] e [6]: Lobato (2011); [7] e [8]: YANG et al. (2014).

Como será discutido adiante, a composição apresentada tem diversas consequências: torna o biogás um gás de efeito estufa e um combustível com diversas impurezas, o que dificulta seu uso na forma bruta e faz das etapas de tratamento parte importante do processo de aproveitamento energético, abrindo possibilidades como a geração de energia elétrica e a produção de biometano.

\subsection{Sustentabilidade ambiental do biogás}

Nota-se, da Tabela 1, que o componente presente em maior quantidade no biogás é o metano. Trata-se de um hidrocarboneto combustível, que qualifica o biogás como um energético.

Por outro lado, o metano também é um gás de efeito estufa (GEE). A capacidade de interferir no sistema climático tem como uma das métricas o potencial de aquecimento global, ou global warming potential (GWP), em inglês. O GWP do metano, em um horizonte de 100 anos, é 28 vezes maior do que o do dióxido de carbono, substância de referência (IPCC, 2013).

Considerando este valor, as emissões de metano corresponderam a $20 \%$ do total das emissões antropogênicas de GEE em 2010. Há outras métricas, como o potencial de mudança 
na temperatura global, ou global temperature change potential (GTP), em inglês, que tem como consequência resultados diferentes para a quantificação das mudanças climáticas (IPCC, 2013).

Portanto, por meio da biodigestão com captura do biogás, pode-se realizar sua combustão transformando o metano em gás carbônico e água, reduzindo a contribuição para o efeito estufa, em termos de $\mathrm{CO}_{2}$ equivalente $\left(\mathrm{CO}_{2} \mathrm{eq}\right)$ - uma forma de quantificação das emissões ponderadas pelo GWP (IPCC, 2013). A captura e queima do biogás também é importante em aterros sanitários, em que a fração orgânica do lixo está compactada e coberta e, portanto, é degradada na ausência de oxigênio, gerando metano que seria liberado para a atmosfera.

A combustão do metano pode ainda ser realizada com o aproveitamento da energia resultante, evitando o uso de outras fontes que, por sua vez, podem também emitir GEE na produção e no consumo.

Além dos benefícios citados, a geração de biogás do tratamento de resíduos contribui com o saneamento, em especial na zona rural (BARREIRA, 2011). A produção do biogás, segundo Bley Jr. (2015), "tem reflexos diretos na saúde pública e no meio ambiente”. A prática da digestão anaeróbia controlada tem potencial, entre outras vantagens, de impedir contaminações do solo e das águas (BLEY JR., 2015), e a disseminação de insetos e doenças (BARREIRA, 2011).

Outra possibilidade de tornar a digestão anaeróbia controlada um processo ainda mais sustentável e viável é o aproveitamento do digestato resultante como biofertilizante. Barreira (2011) aponta diversas experiências positivas do uso do biofertilizante de digestão anaeróbia na agricultura, substituindo ou combinado com adubos industriais e defensivos agrícolas. $\mathrm{O}$ biofertilizante, além de gerar uma economia ou fonte de renda para o produtor, também reduz a dependência agrícola do petróleo (BARREIRA, 2011). Os nutrientes presentes no digestato tem atraído atenções e o fazem tornar um produto estratégico para produções agropecuárias (BLEY JR., 2015). A utilização do biofertilizante de lodos de estações de tratamento de esgoto está condicionada ao cumprimento de regulamentações ambientais do Conselho Nacional do Meio Ambiente (CONAMA, 2006).

A energia do biogás é, devido a suas características, considerada renovável (REN 21, 2017). De acordo com Goldemberg e Coelho (2004), a biomassa para geração de energia pode ser classificada em "biomassa tradicional", quando proveniente de desmatamento e utilizada de forma ineficiente, ou de "biomassa moderna", quando produzida e utilizada de forma sustentável. A energia produzida de resíduos da agricultura e resíduos sólidos urbanos, como é 
a do biogás, por exemplo, é um exemplo de biomassa moderna e é definida pelos autores como “fonte de energia sustentável e renovável” (GOLDEMBERG; COELHO, 2004).

A sustentabilidade é um termo controverso em relação aos biocombustíveis. A falta de consenso se dá pelos impactos ambientais na produção de matérias-primas e na produção industrial, como: uso de fertilizantes e efluentes líquidos; emissões atmosféricas; mudança no uso do solo direta e indireta; uso da água; perda de biodiversidade; além da discussão sobre segurança alimentar, entre outras (COELHO et al., 2014).

Esses impactos podem ser significativos na produção, por exemplo, de etanol e biodiesel (COELHO et al., 2014), e também na produção de biogás proveniente de um cultivo próprio para este fim, como é o caso das culturas energéticas (em inglês, energy crops). A utilização de resíduos orgânicos para a geração de biogás, conforme apresentado, é praticamente isenta de problemas como esses. Deve-se garantir, no entanto, a ausência de vazamentos de metano, verificando a cobertura do biodigestor e com a instalação de um queimador, por exemplo (HIJAZI et al., 2016). Ainda, Patterson et al. (2011) apresentam uma seleção de artigos que mostram que o biometano apresenta benefícios ambientais maiores que o biodiesel ou o etanol.

Conforme apresentado, há diversas contribuições ambientais associadas ao processo de digestão anaeróbia e de geração e consumo do biogás, como o tratamento de resíduos e o saneamento, a redução de emissões de GEE pela transformação do metano, a substituição de outras formas de geração de energia e a produção de biofertilizante. Apoiar projetos nesta área, contribuindo para a viabilidade de investimentos, portanto, pode potencializar o aproveitamento das externalidades positivas do biogás. E a viabilidade dos projetos passa por estratégias eficazes de uso deste biocombustível.

\subsubsection{Mudanças climáticas}

A United Nations Framework Convention on Climate Change (UNFCCC), define "mudanças climáticas" ("climate change") como a "mudança do clima que é atribuída direta ou indiretamente à atividade humana que altera a composição da atmosfera global e que é adicional à variabilidade climática natural observada em períodos comparáveis de tempo" (UNITED NATIONS, 1992, pg. 3, tradução nossa). O termo abrange diversas mudanças, incluindo o "aquecimento global”, ou seja, o aumento da temperatura média da superfície do planeta. Entre as diversas declarações sobre a importância desse tema, o ex-presidente dos Estados Unidos Barack Obama, afirmou que "nenhum desafio representa uma ameaça maior para as gerações 
futuras do que as mudanças climáticas", lembrando de efeitos como aumento do nível do mar, secas e a possibilidade de migração em massa, conflitos e fome ao redor do mundo (THE WHITE HOUSE, 2015).

O Painel Intergovernamental sobre Mudanças Climáticas (Intergovernmental Panel on Climate Change - IPCC) está no centro da análise e divulgação científica do tema. No Quinto Relatório de Avaliação - o mais recente - o IPCC considera "inequívoco" o aquecimento do sistema climático e a que a influência humana nesse sistema é "clara" e "crescente". O Painel afirma ter $95 \%$ de certeza que a atividade humana é a principal causa do aquecimento global atual (IPCC, 2014).

Entre as diversas possíveis consequências das mudanças climáticas, IPCC (2014) indica:

- Prejuízos à segurança alimentar, causados, por exemplo, pela redução da disponibilidade de água em regiões subtropicais, perda de biodiversidade marinha e redução na produção de alimentos como trigo, arroz e milho;

- Em áreas urbanas, o aumento dos riscos para pessoas, ativos, economias e ecossistemas, incluindo riscos de ondas de calor, tempestades e precipitação extrema, inundações, deslizamentos de terra e secas;

- Dificuldades para redução da pobreza, aumento de migrações e, indiretamente, aumento do risco de conflitos violentos por amplificar fatores que os podem gerar, como pobreza e choques econômicos;

- Risco da extinção de espécies.

O conjunto de dados de alterações climáticas apresentado no Quinto Relatório de Avaliação do IPCC, e em que se baseiam as conclusões dos cientistas, inclui (IPCC, 2014):

- $\mathrm{O}$ aquecimento de $0,85^{\circ} \mathrm{C}$ na média global de temperatura da superfície continental e oceânica, no período de 1880 a 2012;

- A diminuição da média anual da camada de gelo no Ártico no período de 1979 a 2012 , em uma taxa, muito provavelmente, na faixa de 3,5 a 4,1\% por década;

- O aumento do nível médio do mar em 0,19 metro, no período de 1901 a 2010;

- A acidificação dos oceanos, com a diminuição do pH na superfície em 0,1 , correspondendo a um aumento de $26 \%$ da acidez se medida como concentração do cátion do hidrogênio, desde o início da era industrial.

Após a publicação do relatório, os dados de temperatura média continuaram a mostrar a tendência de aquecimento: desde o início dos registros em 1880, os anos de 2014, 2015 e 2016 
foram os mais quentes, com a média de cada ano superando a do anterior. A temperatura média da superfície do planeta teria excedido em cerca de $1,1^{\circ} \mathrm{C}$ a do final do século XIX (NASA, 2017).

A explicação do aquecimento global e das mudanças climáticas estaria no aumento da concentração de gases de efeito estufa (GEE) e sua característica de reter a radiação emitida pela Terra. Segundo IPCC (2014) esse aumento causa uma variação positiva na força radioativa, que leva a absorção de energia pelo sistema climático e ao aquecimento da superfície.

As emissões de GEE desde a era pré-industrial levaram a concentrações atmosféricas de dióxido de carbono, metano e óxido nitroso sem precedentes, pelo menos, nos últimos 800.000 anos. As concentrações desses gases cresceram, desde 1750, 40\%, 150\% e 20\%, respectivamente, e a concentração de $\mathrm{CO}_{2}$ aumentou, de 2002 a 2011, na taxa mais rápida na média para uma década (2,0 $\pm 0,1 \mathrm{ppm} / \mathrm{ano}$ ) (IPCC, 2014). O valor da concentração atmosférica de dióxido de carbono antes da Revolução Industrial era de cerca de 280 ppm; já em 1958, no início das observações contínuas, era aproximadamente 315 ppm, atingiu 350 ppm na década de 1980 e, em 2013, se registrou um valor acima de 400 ppm (KENNEDY, 2016).

Ao calcular as forças radioativas de outros GEE e relacionando-as à do $\mathrm{CO}_{2}$, o IPCC estimou que a concentração na atmosfera em termos de $\mathrm{CO}_{2}$-equivalente $\left(\mathrm{CO}_{2} \mathrm{eq}\right)$, em 2011, era de $430 \mathrm{ppm}$. Para limitar em $2^{\circ} \mathrm{C}$ o aquecimento em relação aos níveis pré-industriais, os cientistas estimam que essa concentração não deva passar dos 450 ppm, ou, com menor grau de confiabilidade, dos 500 ppm em $\mathrm{CO}_{2}$ eq. Para o primeiro cenário, as emissões de GEE em 2050 devem ser de $40 \%$ a $70 \%$ menores que as emissões de 2010, e nulas em 2100 (IPCC, 2014).

A urgência de ações para a redução de emissões se deve ao estado atual já observado de mudanças climáticas, pelos efeitos futuros da concentração atmosférica já atingida, e também pelo nível atual de emissões de GEE. A Figura 1 mostra a evolução das emissões anuais de dióxido de carbono desde meados do século XIX, com destaque para o crescimento desde a década de 1950 e nos últimos anos. 
Figura 1. Emissões de $\mathrm{CO}_{2}$ antropogênicas globais anuais desde o século XIX

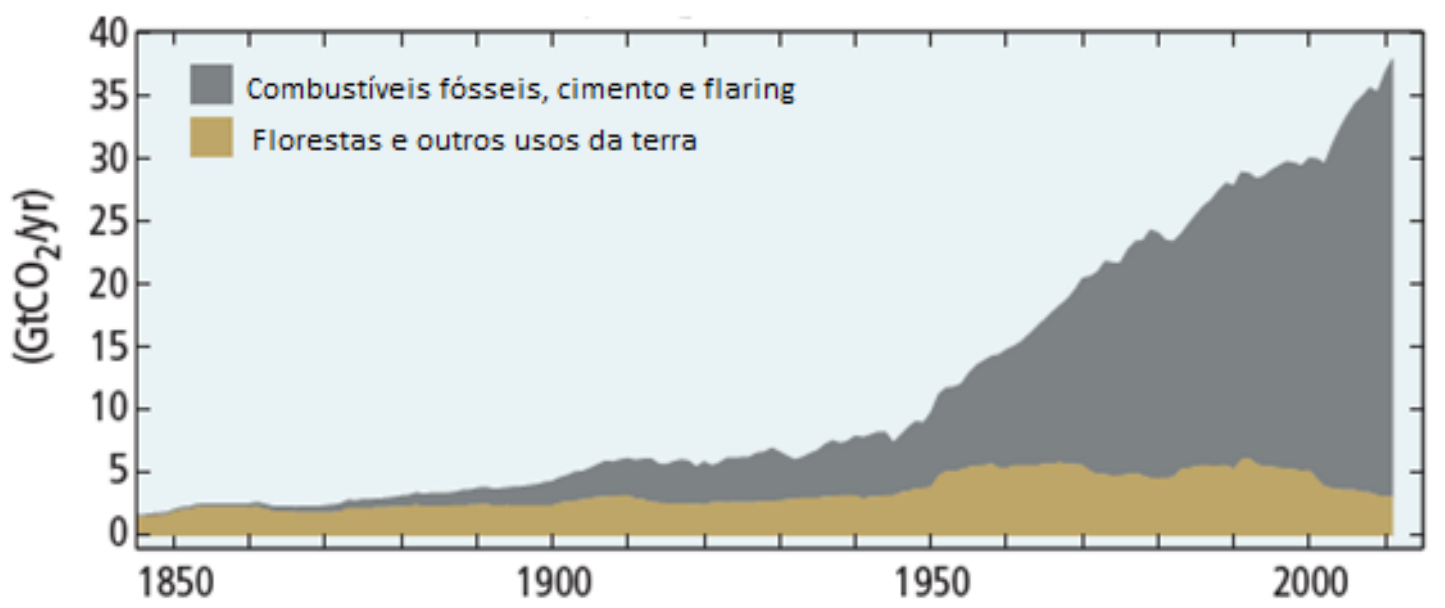

Fonte: adaptado de IPCC, 2014.

Assim, o IPCC afirma que "estabilizar o aumento de temperatura em menos de $2^{\circ} \mathrm{C}$ em relação a níveis pré-industriais requer um abandono urgente e fundamental do business as usual"' (IPCC, 2014, pg. v, tradução nossa).

A complexidade da mudança necessária para manter o aquecimento médio global em $2^{\circ} \mathrm{C}$ é notável. Para Klein (2014), “devido às décadas de negação coletiva, não há opções graduais, incrementais, disponíveis para nós". Segundo a autora, o desafio "não é simplesmente que precisamos gastar muito dinheiro e mudar muitas políticas; é que precisamos pensar diferente, radicalmente diferente, para que essas mudanças sejam remotamente possíveis" (KLEIN, 2014, p. 22-23, tradução nossa).

E, de qualquer forma, persiste a incerteza sobre as consequências da ação humana no sistema climático (AAAS, 2014, pg. 6, tradução nossa):

Fazer com que as temperaturas globais passem certos limites pode iniciar mudanças abruptas, imprevisíveis e potencialmente irreversíveis, que tem impactos massivos e em larga-escala. Nesse ponto, mesmo que nós não adicionemos mais $\mathrm{CO}_{2}$ na atmosfera, processos potencialmente imparáveis estarão em andamento.

É nesse contexto que este trabalho é escrito: da urgência na ação para mitigação das mudanças climáticas e das suas consequências para o planeta e para a humanidade. 


\subsection{Panorama atual do setor energético brasileiro}

Esta seção tem como objetivo avaliar de forma preliminar a matriz energética brasileira, pela relação da produção e consumo de energia com as emissões de gases de efeito estufa e devido à possibilidade de aproveitamento da energia do biogás. Dessa forma, dados que poderão ser utilizados ao longo do trabalho serão apresentados inicialmente, a fim de não prejudicar seu desenvolvimento e o entendimento.

Esta dissertação, conforme descrito na Seção 1, está baseada na comparação entre duas alternativas principais de destinação da energia do biogás: a geração de energia elétrica e a produção de biometano, este um combustível complementar ou substituto do gás natural. Portanto, os setores elétrico e de gás natural serão apresentados em mais detalhes.

Os dados apresentados são baseados nas publicações da Empresa de Pesquisa Energética (EPE), incluindo o Balanço Energético Nacional (BEN), publicação anual que contém "a contabilidade relativa à oferta e consumo de energia no Brasil, bem como dos processos de conversão de produtos energéticos e de comércio exterior" e suas séries históricas (EPE, 2016a)

$\mathrm{Na}$ oferta interna de energia no país prevalecem as fontes fósseis. A Figura 2 mostra como ela foi composta no ano de 2015.

Figura 2. Oferta interna de energia por fonte no Brasil em 2015

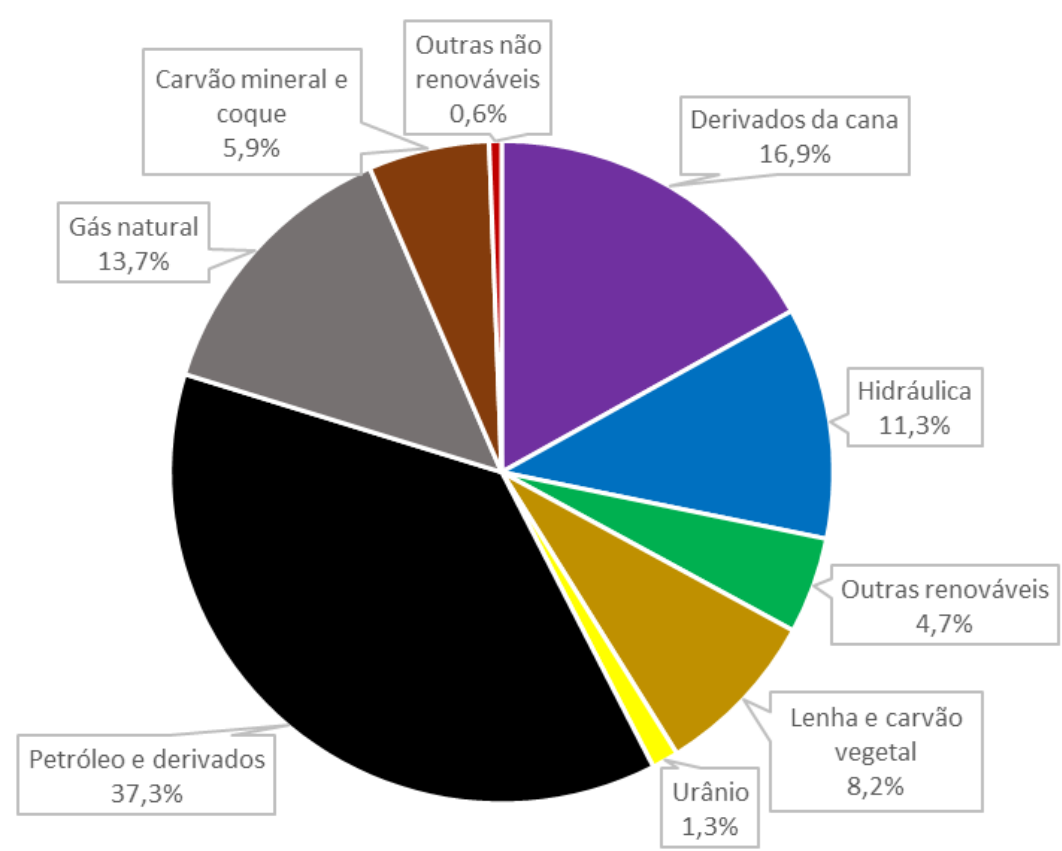

Fonte: elaborado a partir de EPE (2016a). 
Portanto, a oferta de energia no Brasil é composta, em primeiro lugar, por petróleo e derivados. A cana-de-açúcar, renovável, é a segunda maior fonte.

Considerado apenas o setor elétrico, a característica é diferente. A oferta de eletricidade no Brasil é dominada pela fonte hidráulica. Isso lhe confere um status de renovável, apesar das controvérsias acerca da construção de usinas hidroelétricas, em especial as de grande porte (BERMANN, 2001). A Figura 3 apresenta a oferta de energia elétrica do país em 2015.

Figura 3. Oferta de energia elétrica por fonte no Brasil em 2015

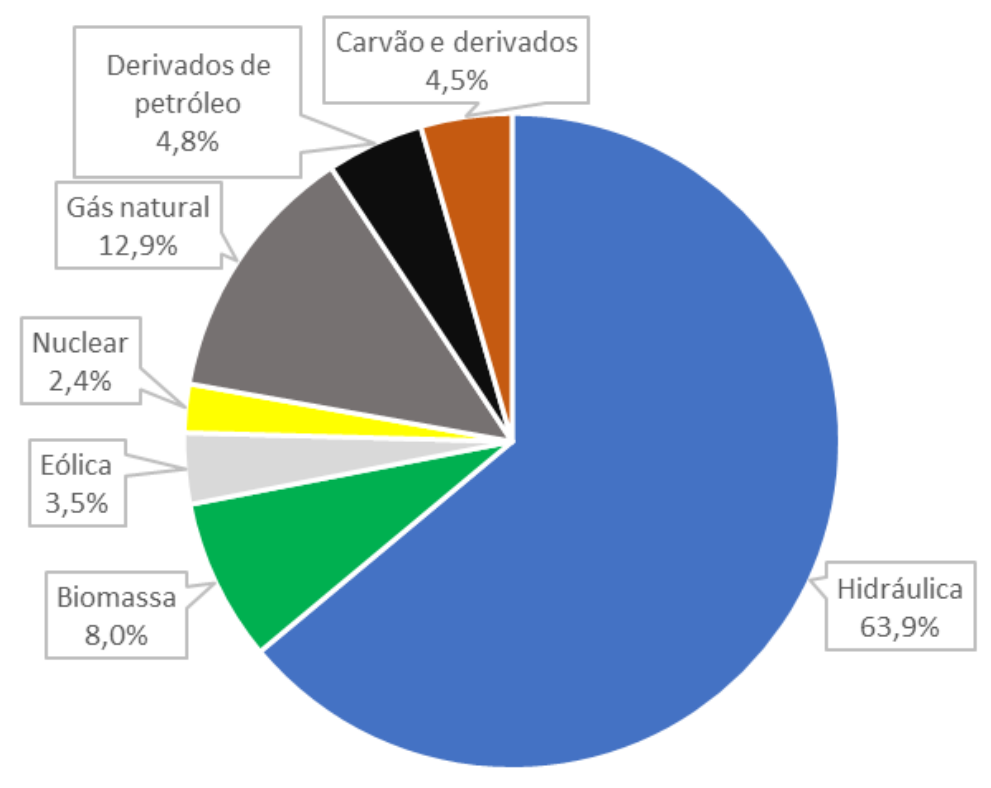

Fonte: elaborado a partir de EPE (2016a).

A Figura 3 aponta que, em 2015, mais de três quartos da oferta de energia elétrica no país foi proveniente de fontes renováveis. Entre as não-renováveis, o gás natural é a fonte de maior geração, à frente dos quase $10 \%$ gerados por meio de derivados de carvão e de petróleo.

O parque de geração reflete os dados de oferta interna de energia. A Figura 4 mostra a capacidade instalada por fonte no país em junho de 2017. 
Figura 4. Capacidade instalada de geração elétrica por fonte no país, em GW, em junho de $2017^{3}$

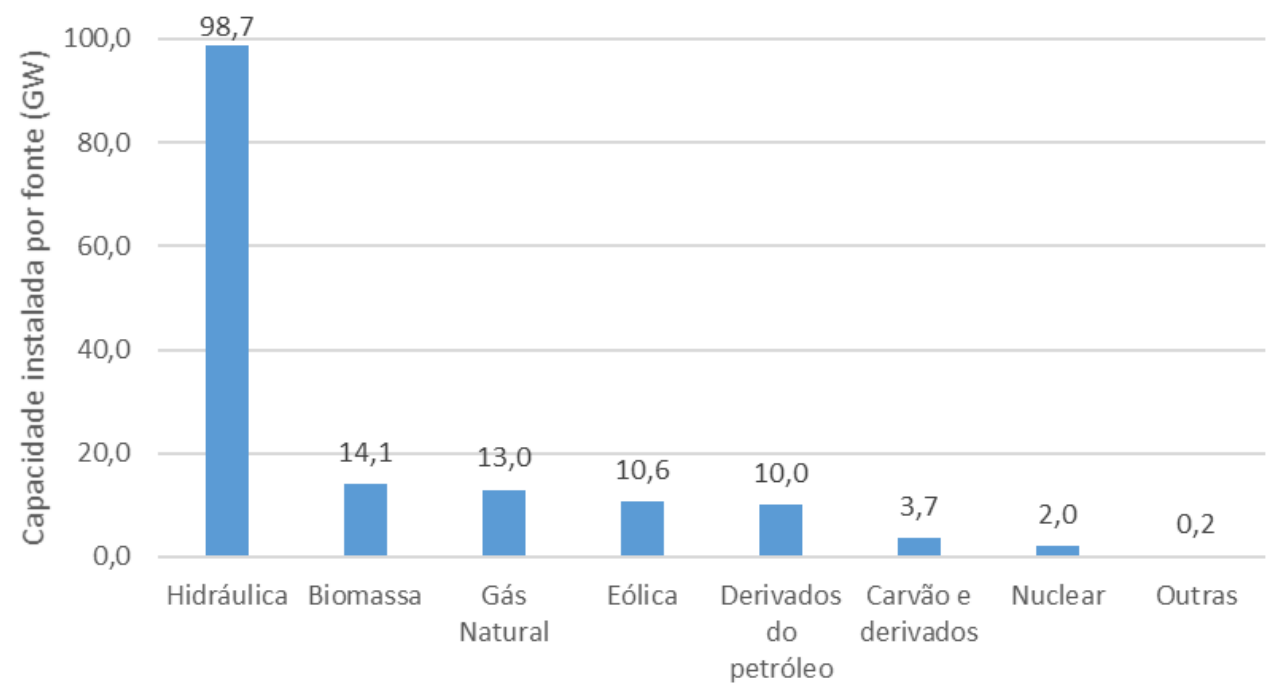

Fonte: elaborado a partir de ANEEL (2017).

Nota-se na Figura 4, novamente, a predominância da fonte hidráulica, desta vez na capacidade de geração, representando cerca de $65 \%$ do total.

O consumo de energia elétrica tem crescido nos últimos anos, de 390 TWh em 2006 para 523 TWh em 2015, apesar da redução de 2014 para 2015 (EPE, 2016a). A previsão do Plano Decenal de Expansão de Energia (PDE) mais recente - até a conclusão desta dissertação -, o PDE 2024 (EPE, 2015a), era de que o consumo no Brasil crescesse a 3,9\% ao ano de 2014 até $2024^{4}$. Portanto, há necessidade de expansão da capacidade de geração, e as hidroelétricas continuam a fazer parte dos planos. $\mathrm{O}$ acréscimo de capacidade instalada previsto para o país de 2015 a 2024, com base nessa premissa, é apresentado na Figura 5.

\footnotetext{
${ }^{3}$ Correspondente a potência fiscalizada; excluindo importações

${ }^{4}$ Após a publicação do PDE 2024, o contexto econômico se alterou, com redução do PIB e do consumo de energia. O contexto político também fez com que o PDE seguinte fosse o PDE 2026, lançado no segundo semestre de 2017, período em que esta dissertação já havia sido concluída. No entanto, a previsão do PDE 2024 se mantém relevante para avaliação das características indicativas da expansão da geração no setor elétrico brasileiro.
} 
Figura 5. Acréscimo anual previsto de potência instalada por tipo de fonte no Brasil, de 2015 a 2024

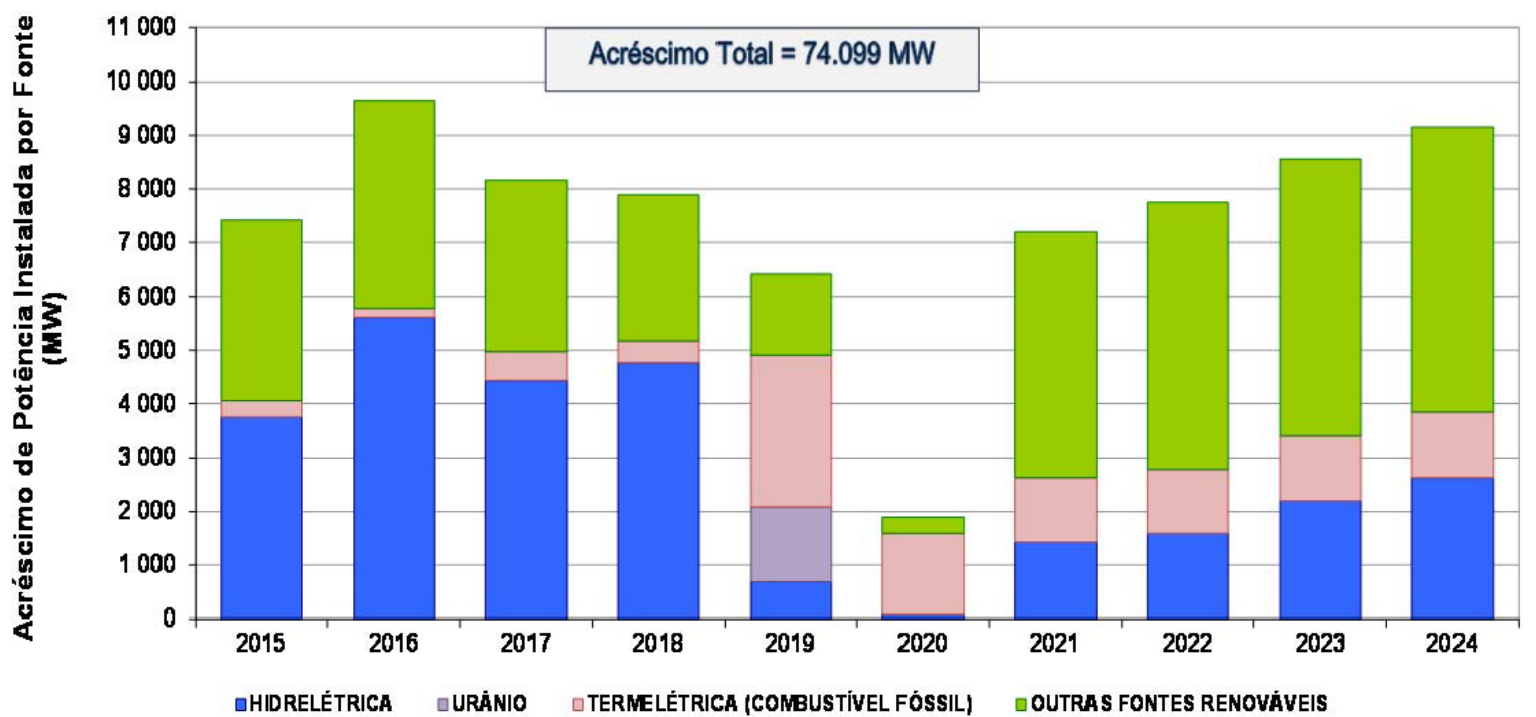

Fonte: EPE (2015a).

Destaca-se, além do crescimento previsto para as hidroelétricas principalmente até 2018, a participação das "outras fontes renováveis" no aumento da capacidade instalada de geração elétrica do país. Trata-se da energia de pequenas centrais hidrelétricas, da biomassa, eólica e solar. Entre elas, o destaque do relatório é dado para as usinas eólicas, com grande expansão projetada na região Nordeste (EPE, 2015a).

A prioridade pelas fontes hidráulica e eólica é justificada com base nos preços competitivos das duas fontes nos leilões de contratação de energia. À expansão de pequenas centrais hidrelétricas $(\mathrm{PCH})$ e da biomassa, por outro lado, são colocadas ressalvas. Para as PCH é considerado o impacto do processo de licenciamento ambiental na sua competitividade. Para a biomassa, destacada a geração por resíduos da cana, é avaliado que o desenvolvimento dessa fonte depende de investimentos sujeitos à volatilidade do setor de açúcar e álcool (EPE, 2015a).

É notável a diversidade de fontes competindo pela expansão do setor elétrico. A medida da possibilidade de contribuição de cada fonte pode ser avaliada pelo seu potencial energético.

O potencial eólico brasileiro foi estimado, em 2001, em 143,5 GW (CRESESB, 2001). Esse valor é próximo a toda a capacidade atual de geração do Brasil, mostrada na Figura 4. Atualmente, avanços na tecnologia, como o aumento da altura e do diâmetro do rotor de torres comerciais (IEA, 2013), certamente elevam consideravelmente o potencial, mesmo que áreas com restrição para receber parques eólicos estivessem contabilizadas (TOLMASQUIM, 
2016a). A expansão dessa fonte tem se destacado nos últimos anos: a capacidade instalada em 2010 era menor que 1 GW (ABEEÓLICA, 2017), em sete anos chegou aos 10,6 GW destacados na Figura 4.

Segundo Tolmasquim (2016), o potencial hidroelétrico total no Brasil era de 172,4 GW, enquanto as plantas em operação somavam 104,6 GW, restando 67,7 $\mathrm{GW}$ de projetos inventariados. Destes, no entanto, cerca de $66 \%$ são projetos nas regiões hidrográficas Amazônica e Tocantins-Araguaia. Cerca da metade do potencial na Amazônia está localizado em áreas protegidas, e a região é caracterizada pela distância dos principais centros de carga, e rios com baixa queda d'água e padrão fortemente sazonal.

Para Bermann (2001), com aspectos ainda mais pronunciados na Amazônia, projetos de hidroelétricas, especialmente as de grande porte, podem ser considerados insustentáveis devido a seus diversos impactos socioambientais: alteração de regimes hidrológicos, emissão de gases de efeito estufa oriundos do alagamento dos reservatórios, deslocamento de populações ribeirinhas e perda da biodiversidade.

Alterada a lógica atual ou, ao menos, se os custos socioambientais fossem adicionados aos custos da energia elétrica de todas as obras, portanto, outras fontes de energia poderiam ocupar parte do espaço das hidroelétricas na expansão da capacidade de geração - a energia do biogás entre elas, em especial se a tendência for direcionada para geração distribuída.

Destaca-se também o potencial da geração distribuída com energia solar fotovoltaica; apenas o potencial para instalação em residências seria capaz de gerar 287,5 TWh por ano, correspondente a $230 \%$ do consumo residencial de 2013 (EPE, 2014c).

Ainda da Figura 5, nota-se que a geração termoelétrica por fontes fósseis também tem previsão de novos projetos, acrescentando 10,5 GW até 2024 (EPE, 2015a). A tendência, segundo o planejamento, é que o combustível dessas térmicas seja o gás natural, exceto em "casos de inviabilidade deste combustível", sendo uma alternativa o uso do carvão, em detrimento de óleo combustível e diesel. Comparado às demais fósseis, o gás natural emite consideravelmente menos $\mathrm{SO}_{2}, \mathrm{NO}_{\mathrm{X}}$, material particulado e $\mathrm{CO}_{2}$ para a mesma quantidade de energia (GOLDEMBERG; LUCON, 2012).

Portanto, o gás natural tende a ganhar importância na geração elétrica, de sua participação que correspondeu a 12,9\% do setor em 2015. Da oferta interna de energia, esse combustível compôs $13,7 \%$, sendo a terceira principal fonte, sendo a maior participação dos últimos 10 anos (EPE, 2016a). 
O consumo de gás natural se dá em diversos setores, com destaque, em 2015, para a própria geração de energia elétrica, e para o setor industrial, que corresponderam, respectivamente, a 43,0\% e 26,4\% do consumo total de 42,8 bilhões de metros cúbicos (EPE, 2016a). A evolução do consumo de gás natural por setor, exposta na Figura 6, revela que a geração de energia elétrica com gás é muito variável ano a ano, conforme a demanda varia pela característica do setor elétrico, de base hidráulica. Esse consumo apresentou aumento relevante de 2011 até 2015, chegando a quase metade do consumo total dessa fonte.

Figura 6. Consumo anual de gás natural no Brasil, por setor, de 2006 a 2015

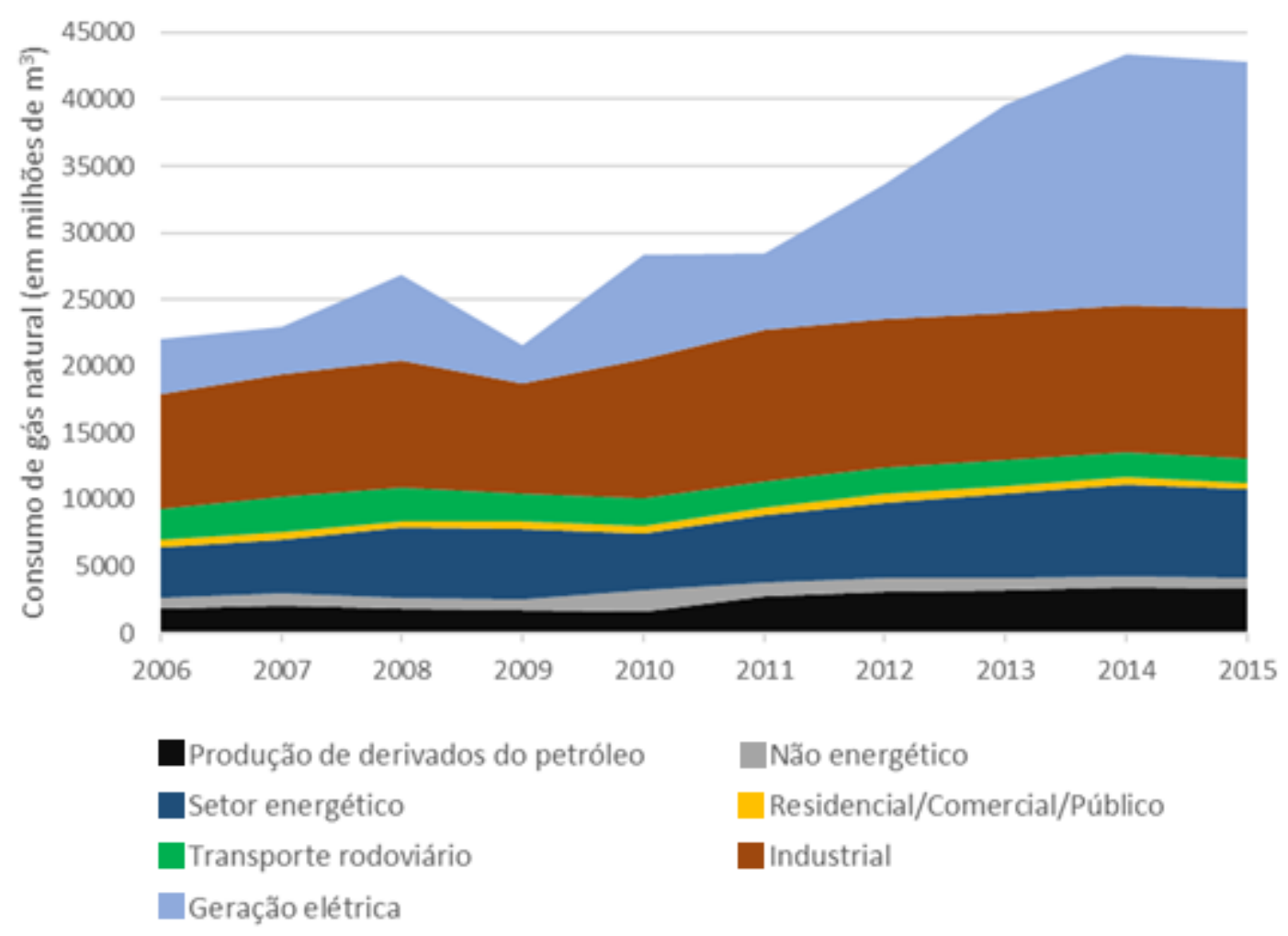

Fonte: elaborado a partir de (EPE, 2016a).

Nota-se também que o setor de transportes, para o qual o biogás, na forma de biometano, é avaliado com expectativa baseado principalmente em experiências internacionais (PROBIOGÁS, 2016b; VEIGA, 2016; IRENA, 2017), tem pequena participação na destinação do gás natural. Apenas $4,1 \%$ do consumo total de gás natural brasileiro foi neste setor (EPE, 2016a). 
A demanda de energia no setor de transportes é dominada pelo transporte rodoviário, que corresponde a 93,1\% do seu consumo energético, e no qual se dá todo o consumo de gás (EPE, 2016a). A participação dos combustíveis no transporte rodoviário é apresentada na Figura 7.

Figura 7. Participação, em termos de energia, dos combustíveis no setor de transporte rodoviário do Brasil, em

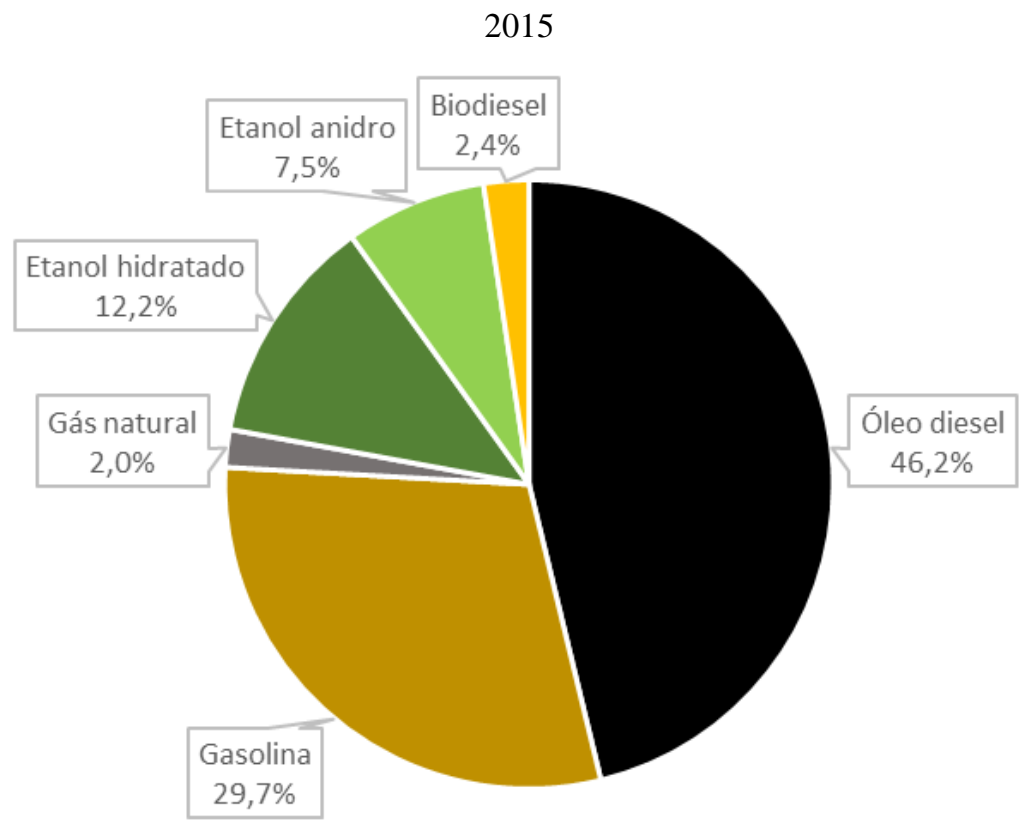

Fonte: elaborado a partir de (EPE, 2016a)

A Figura 7 mostra que o transporte rodoviário é dominado pelos fósseis diesel e gasolina, representando 75,9\% do consumo total em 2015, representando oportunidade de transformação. A participação dos renováveis etanol e biodiesel soma 22,1\%, mas com perspectivas positivas para o futuro. O biodiesel, em 2006, tinha produção praticamente nula no país (EPE, 2016a). Sua tendência de crescimento, movida pela obrigatoriedade de mistura ao óleo diesel, deve continuar com a aprovação do aumento progressivo do percentual da mistura para 8\%, já em vigor em 2017 (BRASIL, 2017), para chegar a 10\% em 2019 (BRASIL, 2016a). A expectativa da EPE para a oferta de etanol também é de crescimento, devido ao aumento da área plantada de cana-de-açúcar, da produtividade por área e melhoria da qualidade da cana (EPE, 2015a).

O gás natural, por sua vez, representa apenas $2 \%$ do consumo de energia rodoviário, como apontou a Figura 7. A Figura 8 mostra que a tendência, nos últimos anos, é de perda de participação e redução em termos absolutos no consumo de gás natural no setor. 
Figura 8. Consumo e participação do GN no setor de transportes rodoviário no Brasil, de 2006 a 2015

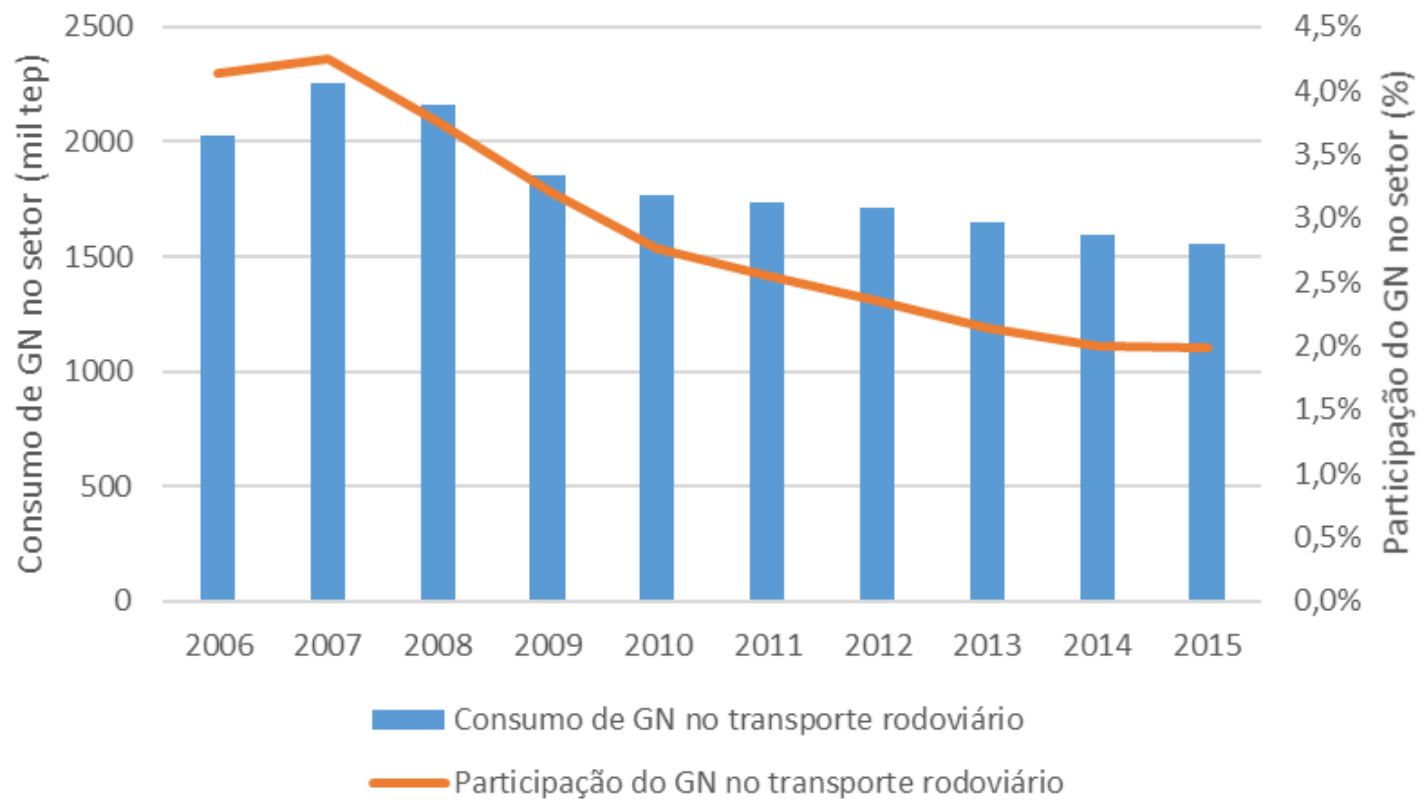

Fonte: elaborado a partir de (EPE, 2016a).

Apesar de também ser um combustível fóssil e não-renovável, pode haver benefícios ambientais e econômicos da utilização do gás natural em relação a gasolina que gerem interesse na adaptação dos motores para utilizarem gás: a geração de emissões menores de $\mathrm{CO}_{2}$ e $\mathrm{CO}$, ainda que apresente níveis maiores de emissões de hidrocarbonetos e $\mathrm{NO}_{\mathrm{X}}$ nos veículos adaptados (CETESB, 2014a); e menor custo por quilômetro rodado (PAVANI, 2012), dependente da variação dos preços dos combustíveis. Segundo MME (2016), em São Paulo em fevereiro de 2017, o preço do gás natural veicular representava cerca de metade do preço da gasolina, em termos de energia.

\subsection{Potencial energético do biogás}

O cálculo do potencial energético do biogás é comumente baseado em estimativas da geração de resíduos. Existem, no entanto, diversas metodologias, considerações e suposições a serem feitas para se chegar a um resultado e, consequentemente, é comum haver divergências nos dados finais. Nesta seção, serão apresentados trabalhos que calcularam o potencial de produção de biogás no Brasil, evidenciando a discrepância entre os valores.

Zanette (2009) realizou um levantamento do potencial energético do biogás de diversas fontes no Brasil. Segundo o autor, algumas características do país contribuem para aumentar 
esse potencial, como a concentração da população em grandes centros urbanos e a "expressiva" produção agropecuária e agroindustrial. O estudo considera que o potencial seria superior a 100 milhões de metros cúbicos $\left(\mathrm{m}^{3}\right)$ de metano por dia, divididos em até 66,3 milhões de resíduos agropecuários, 15,8 milhões em aterros sanitários, 12,7 milhões de efluentes industriais e 7,3 milhões de estações de tratamento de efluentes.

No entanto, para essa estimativa, foram utilizadas suposições como universalização dos serviços de coleta e tratamento de efluentes e disposição de resíduos sólidos urbanos, além do aproveitamento do biogás da pecuária extensiva, que corresponde a 46,4 milhões de $\mathrm{m}^{3}$ diários e apresenta dificuldade de coleta e tratamento dos resíduos. De fato, Zanette (2009) ressalta que o potencial deve ser "avaliado de maneira conservadora", lembrando que a escala também é um fator decisivo para os custos dos projetos, o que pode reduzir ainda mais o potencial economicamente viável.

A estimativa da Associação Brasileira de Biogás e Biometano (ABiogás) é de um potencial total no país de cerca de 23 bilhões de $\mathrm{m}^{3}$ de biogás por ano - cerca de 63 milhões por dia -, considerando o biogás composto de 60\% de metano. Desse potencial, 12 bilhões anuais seriam do setor de cana-de-açúcar, 8 bilhões de alimentos e 3 bilhões de outros resíduos (ABIOGÁS, 2015).

A EPE realizou um inventário energético de resíduos rurais no Brasil. Para o cálculo do potencial, foram consideradas unidades de $1 \mathrm{MW}$ de potência, correspondendo a $450 \mathrm{~m}^{3} / \mathrm{h}$, em dois cenários. No primeiro, foram avaliados apenas os resíduos da pecuária, e no segundo, foi incluída a codigestão com 30\% de biomassa agrícola. Segundo a (EPE, 2014a), o potencial técnico no primeiro cenário seria de 3,5 GW e, no segundo, de 4,3 GW de capacidade instalada de geração elétrica. Foi avaliado também o potencial de produção de biometano, considerando uma eficiência de $70 \%$ no processo de purificação. No primeiro cenário, seria possível produzir 14,3 milhões de $\mathrm{m}^{3}$ de metano por dia, e no segundo, 17,6 milhões (ou 5,2 e 6,4 bilhões por ano, respectivamente). Nesse estudo não foi considerado o aproveitamento do biogás de vinhaça.

Segundo levantamento de Salomon (2007), o potencial energético de produção de biogás no Brasil é de cerca de 4 bilhões de $\mathrm{m}^{3}$ por ano. Os maiores potenciais são provenientes da vinhaça, com 2,7 bilhões, e dos resíduos urbanos em aterros, com 1,2 bilhão. De acordo com o estudo, a capacidade instalada de geração de energia elétrica correspondente seria de cerca de $1,1 \mathrm{GW}$, utilizando grupos geradores de $80 \mathrm{~kW}$ com rendimento de $29 \%$. 
Levantamento do potencial apenas no estado do Paraná encontrou que seria possível gerar 8,7 bilhões de $\mathrm{m}^{3}$ de biogás por ano (SENAI, 2016). A maior parte desse potencial se encontra em cervejarias, correspondendo a 5,8 bilhões, e na pecuária, abatedouros e frigoríficos, chegando a 1,8 bilhão de $\mathrm{m}^{3}$, seguidos de resíduos da indústria de papel e celulose, resíduos urbanos e da vinhaça.

Segundo ARSESP (2016), a Secretaria de Energia e Mineração do Estado de São Paulo estima um potencial de produção de biogás maior que 20 milhões de $\mathrm{m}^{3}$ por dia, ou seja, maior que 7,3 bilhões anuais. A maior parte desse potencial tem como insumo a vinhaça. No Plano Paulista de Energia, a Secretaria estimou ser possível gerar 4,4 TWh/ano de eletricidade fazendo a biodigestão da vinhaça no estado (SEE, 2012).

Bernal et al. (2017) calcularam o potencial de geração de eletricidade apenas do biogás de vinhaça no Brasil em 3,3 TWh/ano. Segundo os autores, o potencial economicamente viável é reduzido para 2,2 TWh/ano.

Em relação ao potencial de resíduos sólidos urbanos e aterros sanitários, os resultados podem ser ainda mais divergentes. Lino e Ismail (2011) apresentam um potencial em aterros de apenas 41,7 MW de potência para geração de energia elétrica. Estudo de Arcadis Tetraplan (2010) pesquisou 56 locais e chegou a uma produção de 1,6 bilhão de $\mathrm{m}^{3}$ de biogás anuais, correspondendo a 311 MW, em 2010. Para Santo Filho (2013), avaliando todos os municípios brasileiros, o potencial em 2013 era de 983 MW, e a expectativa para 2020 era de 1.602 MW.

Segundo cálculos da EPE, há potencial para capacidade instalada de $311 \mathrm{MW}$ se for aproveitado o gás de aterro e $868 \mathrm{MW}$ se for feita a digestão anaeróbica da fração orgânica do lixo. Seria possível produzir 1,9 e 4,2 milhões de $\mathrm{m}^{3}$ de biometano por dia, respectivamente, considerando a eficiência no tratamento do biogás em 70\% (EPE, 2014b).

O potencial energético de biogás em estações de tratamento de esgoto, por sua vez, pode chegar a 1 TWh por ano em 2040, segundo Santos, Barros e Tiago Filho (2016). Nesse estudo, foi avaliado apenas o potencial em estações em cidades com mais de 300 mil habitantes, considerado o mínimo para viabilidade econômica. Valente (2015), considerando também uma escala mínima, considerou haver um potencial de 815 MWh/ano. Costa, D. (2006) avalia apenas o estado de São Paulo, descobrindo ser possível gerar $270 \mathrm{mil} \mathrm{m}^{3}$ de biogás por dia, se todo o esgoto fosse tratado por digestão anaeróbia. Segundo ele, esse valor equivale a uma capacidade instalada de geração elétrica de 20,8 MW, sendo 2,9 MW em 5 unidades da Grande São Paulo. Segundo ARSESP (2016), o mesmo potencial no estado de São Paulo chega a 204 MW. 
A discrepância entre os valores mostra que são necessários e relevantes levantamentos precisos e claros na forma de cálculo - os resultados são muito dependentes das premissas e da metodologia empregada. A identificação e percepção do potencial energético dessa fonte é importante para a formulação de políticas para o setor de biogás e para que o setor seja, cada vez mais, considerado no planejamento do setor energético.

É importante notar que, para cada tipo de matéria-prima, há uma característica do potencial energético. Resíduos urbanos, como a fração orgânica dos resíduos municipais e efluentes domésticos, por definição, se localizam em centros urbanos, portanto são concentrados e tendem a estar próximos à demanda de energia e infraestrutura energética; por outro lado, resíduos agrícolas tendem estarem dispersos no território e pouco concentrados. Resíduos industriais podem ter características específicas. Para a vinhaça, o maior potencial se encontra no estado de São Paulo, que concentrou 48\% da produção de etanol na safra 2015/2016 (UNICA, 2017). A localização geográfica do potencial é um ponto relevante para o planejamento do aproveitamento da energia e sua viabilidade.

Cabe fazer a ressalva de que outras tecnologias disputam o potencial energético de resíduos e da biomassa com a digestão anaeróbia e a produção de biogás. Ainda, esse potencial, já tecnicamente limitado, se torna muito menor se for considerado apenas o economicamente viável. De qualquer forma, os valores apresentados mostram que há potencial energético para a energia do biogás passar a ter um papel relevante no desenvolvimento da matriz energética brasileira. 


\section{UTILIZAÇÃO E TRATAMENTO DO BIOGÁS}

Há diversas maneiras de se utilizar o biogás. Pode-se optar pela queima direta do biogás sem ou com aproveitamento energético, limpá-lo para a retirada de contaminantes visando melhorar a operação dos equipamentos de combustão, ou até enriquecê-lo, gerando um biocombustível de alta qualidade. Esta seção apresenta as tecnologias envolvidas em cada uma das opções de utilização do biogás.

O uso energético do biogás pode gerar retorno financeiro ao seu produtor, seja reduzindo seus custos de energia, vendendo energia elétrica, ou pela comercialização do biometano. A obtenção de receitas a partir do biogás é uma das principais maneiras de viabilizar o processo de digestão anaeróbia. O objetivo de cada empreendimento, geralmente, é ter a melhor viabilidade econômica, e para cada planta pode haver uma resposta diferente, devido a questões como localização, substrato, escala, entre outras.

\subsection{Queima sem aproveitamento energético}

O valor de potencial de aquecimento global do metano comparado ao do gás carbônico indica que a queima do biogás gerado na digestão anaeróbia reduz emissões em $\mathrm{CO}_{2}$ equivalente. Assim, essa é a alternativa escolhida para o uso do biogás em diversos casos: a queima simples, em queimadores, ou flares, sem aproveitamento da energia gerada.

Mesmo deixando de aproveitar o potencial energético dessa fonte, empreendimentos que escolhem essa opção foram incentivados ao serem reconhecidos pelo Mecanismo de Desenvolvimento Limpo (MDL) pelas emissões evitadas (DUARTE, 2006). A maioria dos projetos de redução de emissão de metano no MDL ainda opta pela queima simples (CETESB, 2014b).

Essa é uma opção para locais em que a produção de biogás é muito baixa, ou com fração de metano pequena, tornando inviável o aproveitamento energético.

Tecnicamente, a combustão pode ocorrer em queimadores abertos ou fechados. Os queimadores abertos são equipamentos simples, consistindo basicamente em um queimador com a chama protegida por um defletor de vento. Suas características levam a uma combustão incompleta do gás e formação de subprodutos indesejáveis. Nos queimadores fechados, a 
queima ocorre em câmaras de combustão sob condições controladas e, assim, a combustão é mais uniforme, quase completa e com emissões reduzidas (LOBATO, 2011).

Os queimadores devem estar presentes em todos os tipos de instalações que geram biogás, pois permitem a segurança da planta contra explosões, o controle de odores e evitar emissões de metano para a atmosfera. Eles podem ser utilizados durante a manutenção ou parada dos equipamentos de geração de energia e/ou de tratamento do biogás, além de momentos com concentração de metano baixa no biogás, que impossibilitam o aproveitamento da energia do biogás bruto. (LOBATO, 2011).

\subsection{Aproveitamento energético do biogás}

Conforme apresentado na Tabela 1, o metano é, em média, o componente em maior quantidade no biogás, tornando-o um combustível possível de ser aproveitado na forma bruta, ou seja, assim que recuperado da digestão anaeróbia, sem passar por nenhum tipo de tratamento. No entanto, pode haver impurezas que prejudicam os equipamentos e a eficiência do processo, tornando importante o processo de limpeza, como é visto na Seção 3.3. Portanto, pode-se realizar a combustão do biogás e utilizar a energia resultante.

Os meios de aproveitamento da energia do biogás são diversos: motores a gás de ciclo Otto; motores com ignição a compressão, ou ciclo Diesel; motores Stirling; turbinas e microturbinas a gás; células a combustível; queima em caldeiras para geração de vapor e/ou eletricidade; fonte de energia térmica em geral (DEUBLEIN; STEINHAUSER, 2008; PROBIOGÁS, 2010; LOBATO, 2011).

As características do biogás bruto fazem com que seu aproveitamento para geração de energia térmica tenha caráter local; ou seja, essa opção faz sentido quando há demanda por calor próxima à geração, devido às dificuldades de transporte em termos de custo e impurezas corrosivas. Como exemplo, são relatadas experiências do uso do biogás para aquecimento ambiental de aviário e de creche para produção de leitões (OLIVEIRA; HIGARASHI, 2006) e para a secagem térmica do lodo de estações de tratamento de esgoto visando a redução de volume e melhoria da qualidade do lodo para aplicação na agricultura (DAVID, 2002).

Outra alternativa é a geração de eletricidade com o biogás. Na prática, corresponde a cogeração, pois é capaz de gerar energia elétrica e calor. Isso porque a eficiência elétrica dos equipamentos disponíveis geralmente não supera $45 \%$ da energia gerada na combustão, restando o calor residual do processo, que pode ser aproveitado. Portanto, é comum que a 
alternativa de geração de energia elétrica seja tratada como cogeração, ou combined heat and power (CHP), em inglês.

Motores a combustão interna e microturbinas, projetados ou adaptados para operar com biogás como combustível, são os equipamentos mais utilizados comercialmente para a geração de energia elétrica (ABREU, 2014) e, portanto, para cogeração.

\subsubsection{Motores a combustão interna}

Em plantas de biogás, os principais tipos utilizados são os motores ciclo Otto e os motores com ignição a compressão, chamados de ciclo Diesel. Esses são motores a combustão interna, nos quais a queima da mistura ar-combustível dentro da câmara de combustão eleva a temperatura e pressão dos gases, cuja expansão movimenta os pistões. Assim, ocorre a transformação de energia química em mecânica. Posteriormente, o movimento aciona geradores de energia elétrica. Esses motores possibilitam a utilização de diversos tipos de combustíveis, líquidos ou gasosos (FIGUEIREDO, 2011; LOBATO, 2011).

A diferença de funcionamento é que nos motores ciclo Otto a combustão é iniciada por centelha, produzida por uma vela de ignição (LOBATO, 2011), enquanto no ciclo Diesel o ar é admitido na câmara de combustão até uma pressão em que a combustão ocorre espontaneamente na presença do combustível (PECORA, 2006), exigindo também a injeção de pequena fração de óleo de ignição (PROBIOGÁS, 2010).

Segundo Probiogas (2015a), os motores ciclo Otto raramente tem potência menor que $100 \mathrm{~kW}$, enquanto os ciclo Diesel estão disponíveis em faixas de potência mais baixas, ambos com vida útil de aproximadamente 60.000 horas de operação. Lucas Jr. (2017) ${ }^{5}$, no entanto, afirma que a realidade no Brasil é distinta: os motores ciclo Otto têm potência menor que os Diesel. Estes são adaptados com a colocação de velas e na taxa de compressão, com tecnologia assimilada para potências de até $420 \mathrm{kVA}$; no entanto, a vida útil seria de cerca de 30.000 horas.

Segundo Lobato (2011), são encontrados motores na faixa de $5 \mathrm{~kW}$ a 5 MW. Para a montagem de uma planta de biogás de maior porte, é comum a utilização de mais de um conjunto moto-gerador em paralelo.

Os motores ciclo Otto podem ter eficiência elétrica de $18 \%$ a $45 \%$, e os com ignição por compressão de $40 \%$ a 47\% (PROBIOGÁS, 2015a).

\footnotetext{
${ }^{5}$ Informação fornecida por Lucas Jr. em sua participação na Comissão Julgadora desta dissertação.
} 
Em casos em que o biogás apresenta teores de metano menores que 50\%, foi observado que a eficiência dos motores ciclo Otto cai drasticamente, devido ao baixo poder calorífico (FIGUEIREDO, 2011). Assim, é recomendado que o uso seja limitado para biogás com teor de metano maior que 45\%, sob o risco de parada (PROBIOGÁS, 2010). Dependendo da composição média e da variação no tempo, portanto, pode ser necessário o tratamento do biogás.

Segundo Deublein e Steinhauser (2008), quase a totalidade das unidades de cogeração na Europa utilizam motores.

\subsubsection{Microturbinas a gás}

As microturbinas são turbinas a gás de pequeno porte, com potência de até $200 \mathrm{~kW}$ (PROBIOGÁS, 2010), ou seja, possibilitam a geração de eletricidade em pequena escala (FIGUEIREDO, 2011). O sistema é composto de uma câmara de combustão e um compressor. Na câmara de combustão o combustível é queimado na presença de ar comprimido. A queima do biogás aumenta a temperatura e expande o volume e, assim que os gases atingem a turbina, liberam energia e a movimentam em torno de um eixo. $\mathrm{O}$ excedente ao necessário para movimentar o compressor alimenta um gerador elétrico (PROBIOGÁS, 2010).

Comparadas aos motores, as microturbinas são menos resistentes à presença de contaminantes como umidade e siloxanos, mas são mais tolerantes aos compostos de enxofre e a teores de metano menores, até 35\%. Assim, a escolha do tratamento do biogás, se requerido, deve ser adaptada às necessidades do equipamento (PROBIOGÁS, 2010).

A vida útil das microturbinas tende a ser de 80.000 horas de uso, e a sua eficiência é desvantajosa em relação a motores, chegando à faixa de 30\% (PROBIOGÁS, 2010) mas podendo ficar entre $15 \%$ e 25\%, considerada insatisfatória (DEUBLEIN; STEINHAUSER, 2008). Uma das principais vantagens das microturbinas é a baixa emissão de $\mathrm{NO}_{\mathrm{x}}$, que pode estar sujeita a limites máximos do órgão regulador, da ordem de 9 ppm contra até 3.000 ppm nos motores (PECORA, 2006).

Para microturbinas, os custos de investimento são geralmente maiores por potência instalada do que o para motores, mas a expectativa é de que fiquem mais baratas com a popularização do seu uso (PROBIOGÁS, 2010). A simplicidade de projeto, a confiabilidade e facilidade de instalação, entre outras vantagens, podem estimular sua adoção (FIGUEIREDO, 2011). 


\subsection{Tratamento do biogás}

Além do metano, a substância combustível, outros componentes formam o biogás bruto. Todos estes, por não trazerem benefícios ao aproveitamento energético, podem ter sua presença considerada indesejável no biogás.

Das substâncias indesejadas, há as inertes, que apenas reduzem o poder calorífico do biogás, e as danosas, que podem causar problemas em tubulações e nos equipamentos, maior nível de emissões ou serem nocivas à saúde humana (SUN et al., 2015). Nessa divisão, o gás carbônico, cuja concentração no biogás geralmente só é menor que a do metano, é considerado inerte; o sulfeto de hidrogênio, a umidade e os siloxanos - compostos de silício e oxigênio - são considerados danosos.

Há diversos métodos disponíveis para a retirada das substâncias indesejadas, que serão revisados nesta Seção 3.3. A escolha de quais substâncias serão removidas e das técnicas, com suas respectivas características, dependem da qualidade requerida do combustível para a utilização pretendida e da sua composição inicial (LOBATO, 2011; YANG et al., 2014).

\subsubsection{Limpeza do biogás}

A limpeza do biogás (do termo em inglês, cleaning) consiste na retirada de todas as impurezas, exceto do gás carbônico. Essa remoção pode ser desejável para o aproveitamento do biogás em motores e microturbinas, por exemplo, dependendo da composição do biogás bruto. A limpeza também pode ser uma etapa anterior ao enriquecimento no tratamento do biogás, com o objetivo de levar o gás a ter características de qualidade de biometano, de acordo com os requisitos da legislação ou do projeto em si.

As impurezas danosas tratadas na limpeza têm potencial de causar corrosão de tubulações e equipamentos, deposição de material e emissão de gases nocivos. O resultado da limpeza, portanto, pode ser o aumento da vida útil dos equipamentos, a redução de custos e tempo de manutenção, menor número de paradas do sistema e benefícios ambientais, que podem estar submetidos à regulação do órgão ambiental.

O biogás, após a limpeza, se torna um produto que possui menor quantidade de alguns componentes indesejáveis, portanto menos danoso aos equipamentos, mas ainda com teor de metano e poder calorífico muito próximo ao do biogás bruto, devido a presença de gás carbônico. Como etapa prévia à remoção do dióxido de carbono na produção de biometano, os 
requerimentos da limpeza podem ser mais rigorosos, exigindo concentrações menores das impurezas.

Em seguida, será apresentada uma revisão das técnicas de limpeza do biogás para as impurezas mais relevantes: a umidade, o sulfeto de hidrogênio e os siloxanos.

\subsubsection{Desumidificação/secagem}

Na saída do biodigestor ou coletado de aterros, o biogás bruto geralmente é saturado em vapor d'água, cuja condensação nas tubulações e equipamentos pode causar desgastes, como corrosão (PETTERSON; WELLINGER, 2009; PROBIOGÁS, 2010). Combinada com o sulfeto de hidrogênio, a água forma ácidos sulfurosos, substâncias com grande potencial danoso.

É comum que a remoção da água seja realizada em um passo inicial do tratamento do biogás. Foram desenvolvidos diversos métodos, que se distinguem na complexidade e no resultado. O objetivo é obter um gás com ponto de orvalho a uma temperatura menor que a inicial, impedindo a condensação nas temperaturas de operação (DWA, 2011). Como as regulamentações do biometano requerem concentrações de água muito pequenas, em processos com esse objetivo pode ser necessário aplicar métodos de secagem fina.

As duas técnicas mais importantes são a condensação, pela simplicidade, e a adsorção, por permitir uma secagem mais rigorosa do gás. Também são reportadas a utilização de filtros (DWA, 2011) e a desidratação por glicol (PROBIOGÁS, 2010).

A condensação consiste na diminuição forçada da temperatura do gás, que leva parte da água a condensar, permitindo sua retirada (PROBIOGÁS, 2010). Pode-se usar um trocador de calor com um fluido de arrefecimento (DWA, 2011) ou simplesmente enterrar a tubulação de gás no solo (PETTERSON; WELLINGER, 2009) se esta for suficientemente longa (PROBIOGÁS, 2010). O resfriamento geralmente é acompanhado da compressão do gás, que contribui para que o vapor condense; como o aumento da pressão geralmente é requerido, principalmente para a produção e transporte do biometano, as etapas de compressão são utilizadas para remoção do condensado. A técnica de condensação tem a vantagem de eliminar substâncias como gases solúveis e aerossóis (PROBIOGÁS, 2010), pois a água fica em contato com o gás.

A adsorção é um processo que "envolve o contato de uma fase fluida livre com uma fase rígida e permanente, que tem a propriedade de reter e de guardar seletivamente uma, ou mais de uma, entre as espécies contidas inicialmente no fluido" (PERRY; CHILTON, 1986). Essa 
técnica é utilizada na remoção de água para se atingir índices de umidade muito baixos, ou seja, quando o requerimento da secagem é exigente, como para a obtenção de biometano. Entre os materiais adsorventes utilizados estão zeólitos e outras peneiras moleculares, sílica gel e óxido de alumínio (PROBIOGÁS, 2010).

\subsubsection{Dessulfurização}

A formação do sulfeto de hidrogênio $\left(\mathrm{H}_{2} \mathrm{~S}\right)$ se dá pela ação de microrganismos redutores de compostos contendo enxofre, como sulfatos, peptídeos e aminoácidos (PETTERSON; WELLINGER, 2009). O sulfeto de hidrogênio é uma das impurezas mais importantes na composição do biogás, pois promove a formação do ácido sulfuroso e ácido sulfúrico na presença de água. Esses ácidos são muito corrosivos e exigem elevada resistência dos materiais utilizados no sistema, como no biodigestor, tubulação e equipamentos (DWA, 2011; PROBIOGÁS, 2010).

Ainda, na combustão, a presença do $\mathrm{H}_{2} \mathrm{~S}$ pode gerar dióxido de enxofre, composto prejudicial ao meio ambiente e à saúde. Portanto, os limites de concentração de $\mathrm{H}_{2} \mathrm{~S}$ são bastante restritivos em todos os tipos de aplicação de biogás, e seu processo de remoção é necessário e também deve ocorrer em um estágio inicial do processo, protegendo as instalações e garantindo a segurança da planta (ABATZOGLOU; BOIVIN, 2008). Para operação das unidades de cogeração "sem problemas", Deublein e Steinhauser (2008) afirmam que concentrações entre 100 e $500 \mathrm{mg} / \mathrm{Nm}^{3}$ seriam aceitáveis. A ANP, para o biometano, exige até $10 \mathrm{mg} / \mathrm{Nm}^{3}$ (ANP, 2015) - cerca de 7 ppm, nas condições de temperatura e pressão na regulação da agência.

A remoção do sulfeto de hidrogênio é importante para a viabilidade do processo pois seus custos tendem a compor grande parte dos custos totais, inclusive na produção de biometano. Para a limpeza dessa impureza há diversos tipos de tratamento, que podem ser divididos em dessulfurização grossa (do inglês, rough), e a fina (do inglês, fine). Para certas aplicações, apenas a grossa pode ser suficiente. Em casos em que a concentração de $\mathrm{H}_{2} \mathrm{~S}$ exigida é muito baixa, como para a produção de biometano, uma combinação de métodos dos dois tipos pode ser necessária. Dessa maneira, o processo pode ser mais eficiente economicamente e se adaptar a flutuações de concentração do $\mathrm{H}_{2} \mathrm{~S}$ (DEUBLEIN; STEINHAUSER, 2008; PROBIOGÁS, 2015a).

As técnicas, divididas em dessulfurização grossa e fina, estão apresentadas na Figura 9 e descritas a seguir. 
Figura 9. Diagrama com as técnicas de remoção de $\mathrm{H}_{2} \mathrm{~S}$

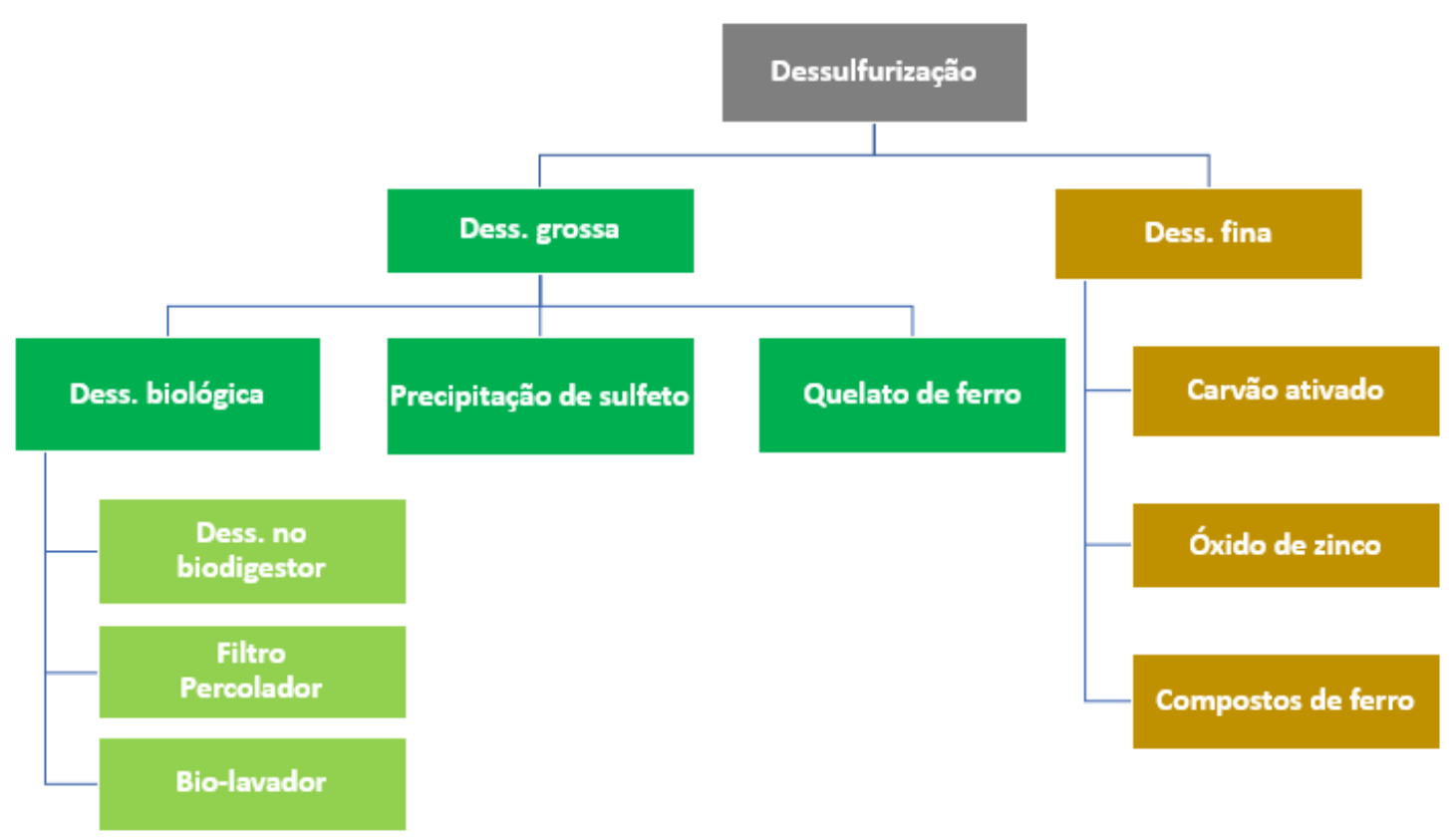

Fonte: adaptado de Probiogas (2015a).

\section{a) Dessulfurização grossa}

As técnicas de dessulfurização grossa são utilizadas para remover grandes quantidades de sulfeto de hidrogênio do biogás, com o objetivo de reduzir a concentração para níveis aceitáveis para o uso na cogeração, ou como preparação para não sobrecarregar uma etapa posterior de dessulfurização fina. Geralmente, os processos de dessulfurização grossa envolvem meios de remoção reutilizáveis, com custos operacionais relativamente baixos por unidade de $\mathrm{H}_{2} \mathrm{~S}$ removida.

A dessulfurização biológica é baseada na capacidade de alguns micro-organismos, geralmente presentes no substrato, de decompor o $\mathrm{H}_{2} \mathrm{~S}$ na presença de oxigênio. Os métodos em que o ar é misturado diretamente com o biogás tendem a impedir a produção de biometano, pela dificuldade da separação posterior do nitrogênio e oxigênio (PROBIOGÁS, 2015a). Alguns métodos foram desenvolvidos visando a impedir o contato do biogás com o ar.

Uma das técnicas de dessulfurização biológica é realizada no biodigestor, e requer a injeção de alta dosagem de ar e alta superfície de contato. Além do contato do biogás com o ar, outros problemas dessa técnica são a falta de controle do processo e a redução da produção de biogás, por se tratar de um processo anaeróbio (que ocorre na ausência de oxigênio). O método do filtro percolador, por sua vez, impede a injeção de ar no biodigestor, mas requer a mistura 
antes da entrada no equipamento, que contém nutrientes e os microorganismos imobilizados no seu interior para realizar a degradação do $\mathrm{H}_{2} \mathrm{~S}$ (DEUBLEIN e STEINHAUSER, 2008).

O método do bio-lavador requer duas colunas. Na primeira, ocorre a absorção do sulfeto de hidrogênio pela reação com solução aquosa de hidróxido de sódio $(\mathrm{NaOH})$. $\mathrm{Na}$ segunda coluna, o NaOH é regenerado pela ação de microorganismos imobilizados e a reação com oxigênio, gerando enxofre elementar (S), que deve ser removido do equipamento (DEUBLEIN e STEINHAUSER, 2008). Dessa forma, o fluxo de biogás não entra em contato diretamente com o ar, tornando o processo adequado para a produção de biometano; ele também é indicado para plantas de grande porte e de concentrações altas de $\mathrm{H}_{2} \mathrm{~S}$ (PETTERSON e WELLINGER, 2009), chegando a atingir concentrações finais de 50 a 100 ppm (PROBIOGÁS, 2015a). Devese atentar para questões de segurança para o uso do $\mathrm{NaOH}$ (DWA, 2011).

A precipitação de sulfeto é outro método que ocorre dentro do biodigestor. Ele se baseia na adição de sais de ferro (cloretos, sulfatos ou hidróxidos) que reagem com o $\mathrm{H}_{2} \mathrm{~S}$, cujos produtos são insolúveis e podem ser removidos com o digestato (DWA, 2011). Por não exigir injeção de ar e chegar a atingir 50 ppm (PROBIOGÁS, 2015a), podem ser utilizados associados à dessulfurização fina para produção de biometano ou em casos em que a concentração exigida não é rigorosa. No entanto, não se pode regenerar os sais e, consequentemente, os custos de operação são altos. A técnica pode ser utilizada se a carga de $\mathrm{H}_{2} \mathrm{~S}$ é baixa ou para evitar altos investimentos (PETTERSON; WELLINGER, 2009; PROBIOGÁS, 2010).

A remoção por quelato de ferro, substância química composta de íons de ferro III e compostos orgânicos, ocorre pela reação com $\mathrm{H}_{2} \mathrm{~S}$, gerando enxofre elementar e íons de ferro II (ABATZOGLOU; BOIVIN, 2008). A regeneração da solução é realizada na presença de oxigênio e pode ocorrer em outro equipamento, caso seja necessário evitar o contato do biogás com o ar - o que aumenta os custos de investimento (DEUBLEIN; STEINHAUSER, 2008).

\section{b) Dessulfurização fina}

A dessulfurização fina é geralmente aplicada para levar o biogás a concentrações relativamente baixas de $\mathrm{H}_{2} \mathrm{~S}$, visando a cumprir com regulamentações rigorosas, como as referentes ao biometano. No entanto, são projetadas para remoção de quantidades pequenas dessa impureza, por terem altos custos operacionais por quantidade removida. Assim, é comum que seja realizada após uma etapa de dessulfurização grossa ou em casos em que a concentração no biogás bruto é pequena. A técnica dominante na dessulfurização fina é a adsorção. 
Na adsorção com carvão ativado, o material é impregnado com substâncias a base de potássio, para aumentar a velocidade da adsorção e a carga total de remoção. $\mathrm{O} \mathrm{H}_{2} \mathrm{~S}$ reage com oxigênio e requer a presença de vapor e, portanto, o processo não é indicado para a produção de biometano, mesmo atingindo até 1 ppm pós-tratamento; se o carvão ativado for impregnado com permanganato de potássio, a presença de ar não é necessária, mas os custos com a matériaprima aumentam (PROBIOGÁS, 2010; DWA, 2011). O carvão ativado utilizado deve ser trocado e descartado, ou regenerado a temperaturas muito altas, acima de $450^{\circ} \mathrm{C}$, em um processo não totalmente eficiente (DEUBLEIN; STEINHAUSER, 2008).

A adsorção em compostos de ferro é um processo de dessulfurização a seco que utiliza hidróxidos ou óxidos de ferro em uma coluna, que reagem com o $\mathrm{H}_{2} \mathrm{~S}$ formando sulfetos de ferro III. O processo pode atingir concentrações finais abaixo de 20 ppm (DWA, 2011) ou até da ordem de $1 \mathrm{ppm}$. Os adsorventes podem ser regenerados por meio da passagem de ar e a manutenção de umidade na coluna; portanto, a operação contínua requer ao menos duas colunas operando alternadamente (DEUBLEIN; STEINHAUSER, 2008).

$\mathrm{O}$ óxido de zinco como adsorvente reage com o $\mathrm{H}_{2} \mathrm{~S}$ para produzir sulfeto de zinco, a temperaturas maiores que $200^{\circ} \mathrm{C}$, aumentando a capacidade com o aumento da temperatura. $\mathrm{O}$ processo é capaz de atingir níveis de pureza inferiores a 1 ppm, o mais eficaz nesse aspecto. As desvantagens são a energia necessária para o aquecimento e os altos custos do óxido de zinco (DWA, 2011).

\subsubsection{Remoção de siloxanos}

Siloxanos são compostos que contém uma ligação entre um átomo de silício e um de oxigênio (Si-O) (PETTERSON; WELLINGER, 2009). A origem do nome para esse tipo de composto vem da combinação das palavras em inglês "silicon" (silício), "oxygen" (oxigênio) e "methane" (metano) (DEWIL; APPELS; BAEYENS, 2006), que representa a composição da estrutura de um siloxano, conforme apresentado na Figura 10. 
Figura 10. Exemplo da estrutura de um siloxano linear

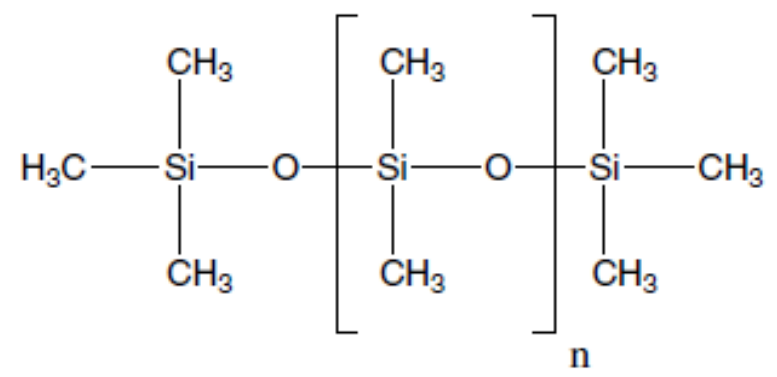

Fonte: DEWIL, APPELS e BAEYENS (2006).

Durante a combustão, os siloxanos são convertidos em dióxido de silício de alta dureza (DWA, 2011) que ficam depositados nos equipamentos causando abrasão e danos às peças. Além desse efeito, os siloxanos podem levar a maiores emissões de monóxido de carbono, entupimento de tubulações, e desativação de materiais do tratamento do biogás. Todos os efeitos negativos levam a maiores custos, provocando uma escolha entre investimento no sistema de tratamento e maiores custos de manutenção (AJHAR et al., 2010).

Os siloxanos não são encontrados na natureza - são originários de cosméticos, desodorantes, sabões e detergentes. A presença de siloxanos é comum no biogás do tratamento de esgoto doméstico (DWA, 2011) e aterros sanitários (AJHAR et al., 2010).

Geralmente, a concentração de siloxanos no biogás é baixa, de maneira que, das composições do biogás apresentadas na Tabela 1, apenas uma das quatro referências utilizadas nota-se sua presença. No entanto, a gravidade dos problemas que o depósito de sílica causa e a dificuldade de remoção fez com que várias técnicas com esse propósito fossem desenvolvidas, e que chame atenção de pesquisas para esse problema (DEWIL; APPELS; BAEYENS, 2006; AJHAR et al., 2010; MATSUI; IMAMURA, 2010).

Uma das técnicas de remoção dos siloxanos é a utilização de filtros de carvão ativado. Esta técnica é considerada uma das mais adequadas pois permite atingir níveis de pureza da ordem da detecção possível atualmente, $0,1 \mathrm{mg} / \mathrm{m}^{3}$ (DWA, 2011). Na comparação com outros adsorventes, como sílica gel e peneiras moleculares, o carvão ativado mostra maiores taxas de adsorção, que é crescente com o aumento do tamanho dos poros e da área superficial (MATSUI; IMAMURA, 2010). O carvão ativado, após a saturação, deve ser trocado e não pode ser regenerado (PETTERSON; WELLINGER, 2009).

O resfriamento do biogás contribui com a remoção dos compostos de siloxanos, e pode ser combinado com o uso de carvão ativado, reduzindo a necessidade de manutenção do filtro. 
A redução da temperatura entre $3^{\circ} \mathrm{C}$ e $12^{\circ} \mathrm{C}$ remove parte dos compostos de siloxanos, mas pode ser necessário atingir $-70^{\circ} \mathrm{C}$ para remoção de mais de $99 \%$, dependendo da volatilidade dos compostos (DWA, 2011). A remoção por resfriamento exige altos custos de investimento e operação (AJHAR et al., 2010).

A lavagem do biogás com solventes líquidos de hidrocarbonetos também é uma técnica que pode remover siloxanos, atingindo taxas de remoção de $60 \%$. Sua utilização não é indicada pela baixa eficiência e risco de mistura do solvente com o biogás (DWA, 2011). A lavagem pode também envolver a utilização de solventes químicos ácidos, como soluções de ácido nítrico e sulfúrico, a temperaturas da ordem de $60^{\circ} \mathrm{C}$, com resultados eficazes. A lavagem com água se provou incapaz de remover os siloxanos do biogás, enquanto outros produtos já apresentaram 99\% de remoção (AJHAR et al., 2010).

\subsubsection{Enriquecimento do biogás a biometano}

O enriquecimento é a etapa de remoção de gás carbônico do biogás previamente limpo, tornando-o um combustível de maior qualidade, denominado biometano. O termo upgrading, utilizado em publicações em inglês e muitas vezes adotado em português, pode se referir ao que aqui se chama de enriquecimento. Outra utilização do termo upgrading - a adotada neste trabalho - é se referir a todo o processo de tratamento do biogás para a produção de biometano, englobando as etapas de limpeza e enriquecimento.

O objetivo do enriquecimento é aumentar a concentração de metano no gás, atingindo valores maiores de poder calorífico. A nova composição possibilita ao biometano se equivaler ao gás natural, permitindo assim a substituição ou a mistura dos combustíveis.

O aumento do poder calorífico do biogás traz, por si só, diversas vantagens. Os custos com transporte por unidade de energia, por exemplo, tendem a se reduzirem pois será necessário levar menor quantidade de matéria, ou seja, a parte inerte do combustível não é carregada. Da mesma forma, os custos de armazenamento diminuem. Essa diminuição de custos se deve ao menor consumo energético para compressão e redução de estruturas, pois a mesma quantidade de energia é obtida com menor volume de gás. Questões dessa ordem são especialmente importantes no caso de aplicações móveis, como veículos: com um combustível de maior densidade energética pode-se, por exemplo, reduzir o tamanho e o peso do armazenamento de combustível e/ou aumentar a autonomia do veículo. 
A similaridade com o gás natural, por sua vez, abre diversas perspectivas para o biometano. O gás natural é uma das fontes de energia mais utilizadas no mundo - foi responsável por 21,2\% da energia primária global em 2014 (IEA, 2016).

O gás natural é rico em metano e, diferentemente do biogás e do biometano, possui outros hidrocarbonetos leves em menores concentrações: etano, propano e butano (ANP, 2008), por exemplo, que também são combustíveis.

O gás natural também possui impurezas, cuja concentração varia de acordo com a fonte. Algumas delas são as mesmas encontradas no biogás: sulfeto de hidrogênio, gás carbônico, entre outras (ANP, 2008).

Em processo de internacionalização cada vez maior de seu comércio (PINTO JR. et al., 2007), o gás natural tem padrões de qualidade atrelados à sua composição. Dessa forma, certa uniformização e tratamento são requeridos, embora os padrões possam variar entre as diferentes regiões do mundo e suas características sejam definidas em faixas e limites (PINTO JR. et al., 2007; ANP, 2008; PETTERSON; WELLINGER, 2009).

O gás natural, após sua extração e processamento em campo, passa por Unidades de Processamento de Gás Natural (UPGN). Nestas unidades pode haver a separação de frações mais pesadas, a desidratação e a retirada de compostos de enxofre, por exemplo (COSTA, H. 2006; PINTO JR. et al., 2007).

No Brasil, a definição da qualidade do gás natural compete à Agência Nacional do Petróleo, Gás Natural e Biocombustíveis (ANP). Para que o biometano possa se aproveitar das características semelhantes e se tornar um substituto para o gás natural, sua composição também é regulada pela mesma agência.

A Tabela 2 apresenta uma comparação entre as características do gás natural e as do biometano, segundo as resoluções ANP n 16/2008 e ANP nº/2015, respectivamente. Há, nestas resoluções, valores diferentes para algumas regiões do país. Os valores comparados são os mais rigorosos, ou seja, de padrão de qualidade mais elevado: das regiões Centro-Oeste, Sul e Sudeste para o gás natural (ANP, 2008), e todas as regiões, exceto "Região Norte - Urucu", para o biometano produzido a partir de produtos e resíduos orgânicos agrossilvopastoris e comerciais (ANP, 2015). 
Tabela 2 - Comparação entre as especificações mais rigorosas para o biometano e o gás natural no Brasil

\begin{tabular}{|c|c|c|c|}
\hline Característica & Unidade & Gás Natural & Biometano \\
\hline \multirow[t]{2}{*}{ Poder calorífico superior (PCS) } & $\mathrm{MJ} / \mathrm{m}^{3}$ & 35 a 43 & $\mathrm{NE}$ \\
\hline & $\mathrm{kWh} / \mathrm{m}^{3}$ & 9,72 a 11,94 & $\mathrm{NE}$ \\
\hline $\begin{array}{l}\text { Índice de Wobbe (razão entre o PCS e a } \\
\text { raiz quadrada da densidade relativa) }\end{array}$ & $\mathrm{MJ} / \mathrm{m}^{3}$ & 46,5 a 53,5 & $\mathrm{NE}$ \\
\hline Metano, mín. & $\% \mathrm{~mol}$ & 85,0 & 96,5 \\
\hline Etano, máx. & $\% \mathrm{~mol}$ & 12,0 & $\mathrm{NE}$ \\
\hline Propano, máx. & $\% \mathrm{~mol}$ & 3,0 & $\mathrm{NE}$ \\
\hline Butanos e mais pesados, máx. & $\% \mathrm{~mol}$ & 1,5 & $\mathrm{NE}$ \\
\hline $\mathrm{O}_{2}$, máx. & $\% \mathrm{~mol}$ & 0,5 & 0,5 \\
\hline Inertes, máx. & $\% \mathrm{~mol}$ & $\left(\mathrm{~N}_{2}+\mathrm{CO}_{2}\right) 6,0$ & $\left(\mathrm{CO}_{2}+\mathrm{O}_{2}+\mathrm{N}_{2}\right) 3,5$ \\
\hline $\mathrm{CO}_{2}$, máx. & $\% \mathrm{~mol}$ & 3,0 & 3,0 \\
\hline Enxofre total, máx. & $\mathrm{mg} / \mathrm{m}^{3}$ & 70 & 70 \\
\hline $\mathrm{H}_{2} \mathrm{~S}$, máx. & $\mathrm{mg} / \mathrm{m}^{3}$ & 10 & 10 \\
\hline $\begin{array}{l}\text { Ponto de orvalho da água a } \\
1 \text { atm, máx. }\end{array}$ & ${ }^{\circ} \mathrm{C}$ & $\mathrm{NE}$ & -45 \\
\hline
\end{tabular}

NE: Não especificado;

Fonte: adaptado de ANP (2008) e ANP (2015).

Nota-se, da Tabela 2, que há mais características reguladas no gás natural em comparação ao biometano, devido a presença de mais substâncias na sua composição. Por essa maior complexidade, no gás natural também são avaliados o poder calorífico superior e o índice de Wobbe, que é a relação entre o poder calorífico superior e a raiz quadrada da densidade relativa do combustível (ANP, 2008). No biometano, o valor dessas características é garantido pela concentração mínima de metano, por ser o único gás combustível presente.

Para a ANP, essa concentração deve ser de 96,5\% em mol. Assim, a concentração máxima de inertes é de 3,5\%, e a de gás carbônico, definida em até 3,0\%. Para atingir tais valores, é necessário garantir o desempenho das unidades de enriquecimento. A concentração de metano no biometano é um dos parâmetros importantes na avaliação desses processos, assim como as perdas de metano e o consumo de energia (PATTERSON et al., 2011). Somente após assegurados os requerimentos do biometano, a escolha por uma técnica de enriquecimento deve ser baseada no menor custo, que são dependentes dos parâmetros citados (SUN et al., 2015). 
Diversos trabalhos afirmam que a escolha do melhor processo de enriquecimento é variável e depende das condições da planta (PROBIOGÁS, 2010; SUN et al., 2015): composição do biogás bruto; requerimentos ou legislação para o biometano; custos e disponibilidade de equipamentos e de matéria-prima; preço da energia elétrica e de venda do biometano; entre outros fatores.

Não há, portanto, uma tecnologia dominante para o enriquecimento do biogás. Dessa forma, encontra-se diferentes processos nas plantas de produção de biometano atualmente em operação. A Figura 11 apresenta o número de plantas por tecnologia de enriquecimento nos países membros da IEA Bioenergy Task $37^{6}$, que cataloga e disponibiliza dados sobre as unidades em operação. O Brasil era um dos membros, com apenas 4 plantas de enriquecimento catalogadas, enquanto o país líder em número de plantas, a Alemanha, tem 188. Ressalva-se o fato de que há diversos países, como Estados Unidos e Japão, com unidades de enriquecimento que não estão incluídos no grupo, que requer participação e investimentos dos membros (IEA BIOENERGY, 2015c).

Figura 11. Número de plantas por tecnologia de enriquecimento nos países membros da IEA Bioenergy Task 37

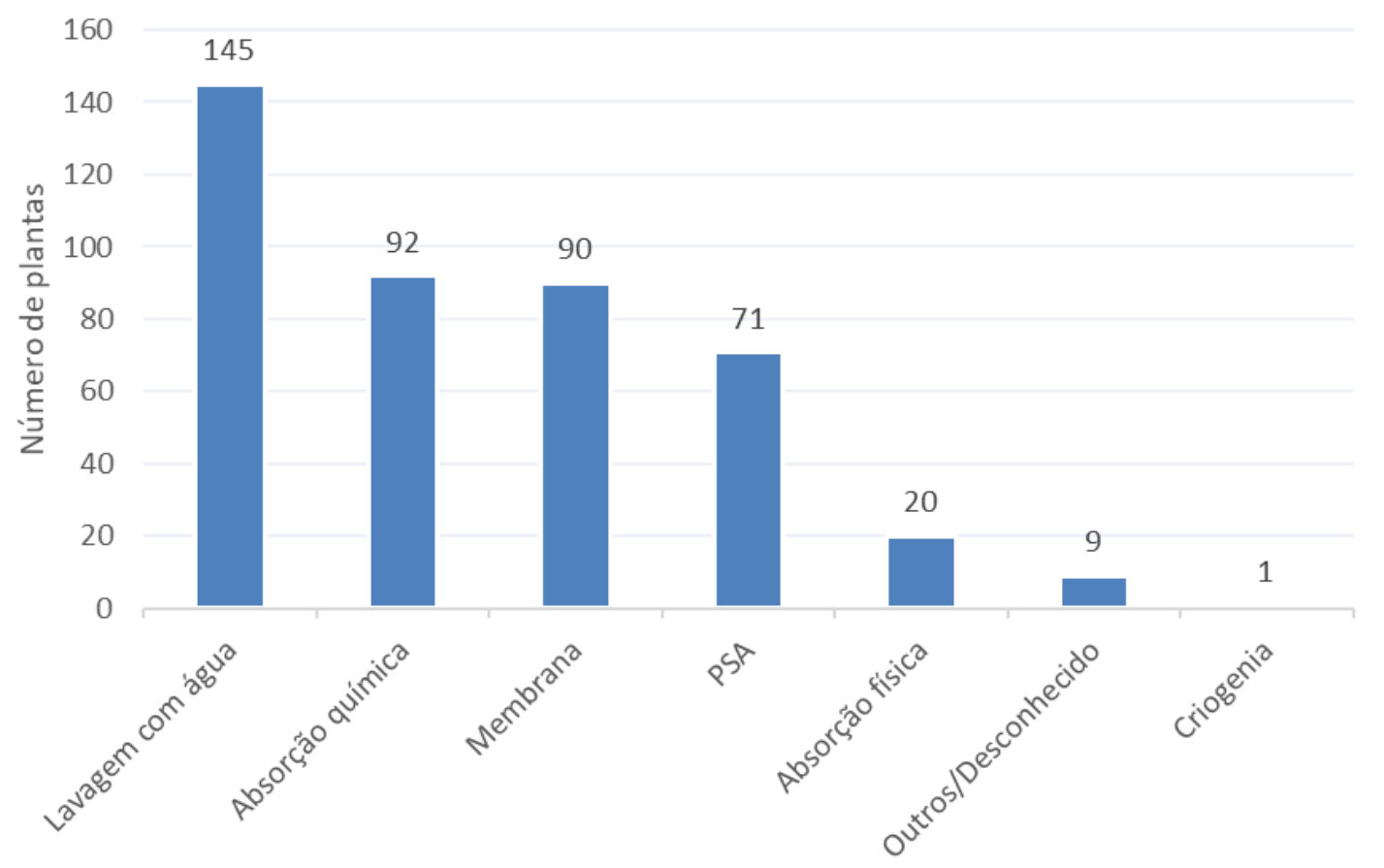

Fonte: elaborado a partir de IEA Bioenergy (2015c).

\footnotetext{
${ }^{6}$ A IEA Bioenergy é uma organização da Agência Internacional de Energia (International Energy Agency - IEA) que tem o objetivo de melhorar a cooperação e a troca de informação entre países com programas nacionais de pesquisa, desenvolvimento e implementação da bioenergia. A organização é estruturada em vários grupos ou forçatarefas, chamados de Tasks. A IEA Bioenergy Task 37 aborda questões relacionadas à sustentabilidade econômica e ambiental da produção e utilização de biogás (IEA BIOENERGY, 2016).
} 
As principais tecnologias de enriquecimento estão apresentadas com mais detalhes em seguida.

\subsubsection{Lavagem com água pressurizada}

A lavagem com água corresponde a um processo de absorção, "em que um ou mais de um componente de uma mistura gasosa é dissolvido num líquido" (PERRY; CHILTON, 1986). O processo geralmente é realizado em uma coluna com recheios sólidos, cuja função é aumentar a área de contato entre o gás e o fluido, facilitando a transferência de massa (PERRY; CHILTON, 1986; PETTERSON; WELLINGER, 2009). A separação se baseia na diferença de solubilidade dos compostos no fluido absorvente.

Para que a remoção do dióxido de carbono seja eficaz, ele deve ser mais solúvel que o metano no fluido absorvente; este é o caso da lavagem com água. $\mathrm{O}$ aumento da pressão e a redução da temperatura aumentam a razão entre as solubilidades do gás carbônico e do metano e a capacidade de absorção no fluido, melhorando a eficiência da separação e reduzindo o tamanho da planta (DEUBLEIN; STEINHAUSER, 2008). Assim, é comum que a água seja pressurizada e resfriada na operação comercial dessa tecnologia - tipicamente, a pressão é de 7 a 12 bar na coluna e a temperatura pode chegar a $5^{\circ} \mathrm{C}$ (DEUBLEIN; STEINHAUSER, 2008; DWA, 2011; PATTERSON et al., 2011).

A água de lavagem é utilizada em apenas uma passagem em algumas unidades, mas é comum seja regenerada e reutilizada na coluna (PATTERSON et al., 2011). A regeneração ocorre com a redução da pressão em duas etapas: na primeira, em um tanque flash, parte do gás absorvido é liberado e, como contém uma fração de metano, é reciclado para a entrada para reaproveitamento; na segunda etapa, a água é totalmente despressurizada em contracorrente com ar atmosférico (DWA, 2011; PATTERSON et al., 2011).

O biometano produzido por esta técnica requer secagem fina posterior, pelo contato do produto com a água de lavagem (DWA, 2011).

De acordo com a Figura 11, a lavagem com água é a técnica mais utilizada entre os países da IEA Bioenergy Task 37, e também é apontada como a mais utilizada na Europa. Além da simplicidade e disponibilidade do fluido, o processo tem como vantagem a flexibilidade da capacidade de tratamento durante a operação (PROBIOGÁS, 2010). A água também absorve sulfeto de hidrogênio e amônia e pode contribuir na limpeza do biogás, mas o efeito corrosivo e a dificuldade de dessorção do $\mathrm{H}_{2} \mathrm{~S}$ geralmente torna a limpeza prévia geralmente necessária (SUN et al., 2015). 


\subsubsection{Absorção química com solventes orgânicos}

O solvente utilizado na absorção química geralmente é composto por aminas, que absorvem e também, nesse caso em especial, reagem quimicamente com o gás carbônico. A seletividade da reação permite perdas de metano muito pequenas, menores que $0,1 \%$ (PETTERSON; WELLINGER, 2009).

Os compostos químicos utilizados são a monoetanolamina (MEA) e a dietanolamina (DEA), em alta pressão. A metildietilamina (MDEA) e a trietanolamina (TEA) permitem a remoção conjunta de gás carbônico e sulfeto de hidrogênio (PROBIOGÁS, 2010).

As vantagens dessa técnica são o elevado grau de pureza do biometano resultante, possível acima de 99\% (PROBIOGÁS, 2010) - o maior entre as técnicas comercialmente competitivas - e as pequenas perdas de metano, dispensando tratamento do gás residual. A baixa demanda de energia elétrica também favorece a absorção química (DWA, 2011; PROBIOGÁS, 2015a). Esses fatores explicam o crescimento do número de unidades que a utilizam, especialmente para fluxos menores (PROBIOGÁS, 2010).

O ponto negativo é a difícil recuperação do solvente, geralmente realizado com vapor d'água (PROBIOGÁS, 2010) e altas temperaturas (DWA, 2011), demandando grande quantidade de energia térmica (PROBIOGÁS, 2015a), principalmente se houver absorção de $\mathrm{H}_{2} \mathrm{~S}$ (PETTERSON; WELLINGER, 2009).

\subsubsection{Absorção física com solventes orgânicos}

A absorção física é uma lavagem com um fluido não reativo que, da mesma maneira que o processo com água pressurizada, absorve seletivamente o gás carbônico do biogás. É possível também a remoção de água e sulfeto de hidrogênio, o que pode dispensar um processo de dessulfurização fina (DWA, 2011); no entanto, Probiogás (2010) afirma que a viabilidade do processo é maior quando o biogás é previamente tratado para a remoção dessas impurezas.

A vantagem do solvente orgânico em relação à água é a maior solubilidade do gás carbônico, o que resulta em estruturas menores para o mesmo resultado. No entanto, os custos de operação, pela qualidade do solvente, tendem a ser maiores (PETTERSON; WELLINGER, 2009). O processo ocorre a cerca de 7 bar e o solvente pode ser regenerado com redução da pressão e temperatura de $50^{\circ} \mathrm{C}$ (PROBIOGÁS, 2010; DWA, 2011) 
Segundo Petterson e Wellinger (2009), o solvente orgânico pode ser um polietileno glicol, que faz parte da mistura de um dos absorventes disponíveis no mercado, o Genosorb (PROBIOGÁS, 2010; PATTERSON et al., 2011)).

\subsubsection{Adsorção com modulação de pressão (PSA)}

A adsorção com modulação de pressão, ou Pressure Swing Adsorption - PSA, é uma técnica que se aproveita da reversibilidade do processo de adsorção seletiva do gás carbônico em materiais como carvão ativado, zeólitos e peneiras moleculares de carbono (DWA, 2011; PROBIOGÁS, 2015a).

O processo de adsorção ocorre sob pressão elevada, de 4 a 7 bar, segundo DWA (2011) e de 6 a 10 bar, segundo Probiogas (2010). Em seguida, uma redução sequencial da pressão, antes que a coluna receba novamente o fluxo de gás, faz com que o gás retido seja dessorvido e o adsorvente, regenerado. O gás dessorvido pode passar por uma coluna não carregada visando a recuperação de metano. A duração dos ciclos de adsorção e regeneração da coluna exige várias colunas para operação, de no mínimo três até nove, sendo geralmente quatro (DEUBLEIN; STEINHAUSER, 2008; PETTERSON; WELLINGER, 2009; PROBIOGÁS, 2015a).

A elevação da pressão do biogás deve ser realizada de forma a evitar contaminações de óleo, que causa prejuízo aos adsorventes, e seguida do resfriamento do gás, que é aquecido durante o processo de compressão (DEUBLEIN; STEINHAUSER, 2008; PROBIOGÁS, 2015a).

A técnica PSA requer limpeza prévia, pois sulfeto de hidrogênio pode ser adsorvido irreversivelmente nos materiais, inutilizando-os, enquanto a presença de água causa destruição dos adsorventes (PETTERSON; WELLINGER, 2009; PROBIOGÁS, 2010). As perdas de metano podem ser particularmente elevadas nesse processo (PROBIOGÁS; 2015a; LEME; SEABRA, 2017)

\subsubsection{Separação por membranas}

O processo de separação por membranas se baseia nas diferentes permeabilidades do material polimérico em relação aos componentes do biogás. Enquanto algumas moléculas são retidas, outras passam pela membrana, que é chamada "semipermeável" (PATTERSON et al., 2011). Para que a separação seja eficiente, a permeabilidade e a seletividade da membrana devem ser elevadas (PROBIOGÁS, 2015a). 
De acordo com Probiogás (2015a), além da separação do $\mathrm{CO}_{2}$, esse processo pode realizar a remoção de $\mathrm{H}_{2} \mathrm{~S}$ e água do biogás. No entanto, DWA (2011) e Leme e Seabra (2017) afirmam ser recomendadas a secagem e dessulfurização fina antes da membrana, para aumentar a durabilidade da membrana e garantir a eficiência da separação.

Há dois tipos de separação por membranas: os processos em alta pressão a seco, da faixa de 8 a 10 bar até maior que 20 bar, e os processos em baixa pressão a úmido, que utilizam um fluido absorvente combinado (DEUBLEIN; STEINHAUSER, 2008; DWA, 2011; PATTERSON et al., 2011).

Como resultado da separação por membranas, pode-se atingir níveis de metano no produto maiores que 80\% (PROBIOGÁS, 2015a). Para alcançar níveis mais elevados, é necessário um processo multi-estágios, capaz de pureza maior que 96\% (DEUBLEIN e STEINHAUSER, 2008; PATTERSON et al., 2011).

\subsubsection{Método criogênico}

O enriquecimento do biogás utilizando o resfriamento a temperaturas muito baixas, chamado método criogênico, permite a obtenção de gases de qualidade elevada, ou seja, biogás com alta concentração de metano, maior que 99\%, além de gás carbônico com baixo teor de metano, menor que 0,1\% (PROBIOGÁS, 2010), permitindo sua comercialização (PATTERSON et al., 2011). O método se baseia nos diferentes pontos de sublimação ou condensação das substâncias; ao resfriar o biogás sob pressão progressivamente, cada substância muda de fase a temperaturas distintas e pode ser separada das demais (PETTERSON; WELLINGER, 2009; PATTERSON et al., 2011) O elevado consumo de energia elétrica faz com que essa técnica ainda seja considerada experimental, mas já há plantas comerciais em operação (SUN et al., 2015).

\subsubsection{Comparação entre as técnicas de enriquecimento}

De forma geral, alguns parâmetros podem diferenciar as tecnologias de remoção de $\mathrm{CO}_{2}$, permitindo a comparação entre os processos e a avaliação de cada um. Com esses objetivos, os indicadores mais analisados são, entre outros (DEUBLEIN E STEINHAUSER, 2008; PROBIOGÁS, 2015; LEME E SEABRA, 2017):

- Grau de pureza em metano no biometano;

- Perda de metano (ou capacidade de recuperação de metano em relação à entrada);

- Consumo de energia (elétrica e térmica); 
- A capacidade de remoção de outras impurezas e a necessidade de pré e pós-tratamentos;

- Consumo do meio absorvente ou adsorvente e capacidade de regeneração;

- Custos de investimento e operação, que dependem das características anteriores.

Algumas referências apresentam valores típicos para os principais parâmetros, organizados na Tabela 3.

Tabela 3 - Comparação entre as principais técnicas de enriquecimento do biogás.

\begin{tabular}{|l|c|c|c|c|c|}
\hline Parâmetro & $\begin{array}{c}\text { Lavagem } \\
\text { com água }\end{array}$ & $\begin{array}{c}\text { Absorção } \\
\text { química }\end{array}$ & $\begin{array}{c}\text { Absorção } \\
\text { física }\end{array}$ & PSA & Membranas \\
\hline $\begin{array}{l}\text { Perda de } \\
\text { metano }\end{array}$ & $\begin{array}{c}\text { Baixa a } \\
\text { média } \\
(0,5-2 \%)\end{array}$ & $\begin{array}{c}\text { Muito baixa } \\
(<0,1 \%)\end{array}$ & $\begin{array}{c}\text { Média a alta } \\
(1-4 \%)\end{array}$ & $\begin{array}{c}\text { Média a } \\
\text { muito alta } \\
(1-8 \%)\end{array}$ & $\begin{array}{c}\text { Média a } \\
\text { muito alta } \\
(1-8 \%)\end{array}$ \\
\hline $\begin{array}{l}\text { Consumo de } \\
\text { eletricidade }\end{array}$ & $\begin{array}{c}\text { Alto a muito } \\
\text { alto }\end{array}$ & Baixo & Alto & Alto & Alto \\
\hline $\begin{array}{l}\text { Demanda } \\
\text { térmica }\end{array}$ & - & Alta & Baixa & - & - \\
\hline $\begin{array}{l}\text { Pureza final } \\
\text { em metano }\end{array}$ & $96-99 \%$ & $>99 \%$ & $>96 \%$ & $>96 \%$ & $80-99 \%$ \\
\hline
\end{tabular}

Fonte: elaborado a partir de Probiogás (2015) e Leme e Seabra (2017).

Cabe notar, no entanto, que os indicadores tendem a ser interdependentes. Por exemplo, pode-se alterar certos parâmetros do processo - como a vazão de água na lavagem - com a intenção de aumentar a concentração de metano no produto, o que pode ter impactos na perda de metano e nos consumos de energia e do meio absorvente. Petterson e Wellinger (2009), por exemplo, relatam que é possível reduzir as perdas de metano, ao custo de aumentar o consumo de energia; essa questão depende da flexibilidade de cada tecnologia.

O requerimento mínimo para a concentração de metano no biometano produzido tende a ser a principal restrição do processo; ou seja, a técnica escolhida deve garantir que o biometano terá a qualidade necessária. Segundo Sun et al. (2015), é fato amplamente reconhecido que os requerimentos de qualidade do biometano e outras circunstâncias locais fazem com que a escolha da tecnologia seja específica a cada planta.

A decisão, portanto, busca a tecnologia mais apropriada, antes de avaliar apenas os custos envolvidos. Os custos, no entanto, avaliados caso-a-caso, podem refletir parte das 
especificidades, como disponibilidade de fonte de calor e os preços da eletricidade (PETTERSON; WELLINGER, 2009).

Com o objetivo de analisar a competitividade da produção de biometano, estimativas de custos do processo de upgrading são importantes, mesmo que não revelem as especificidades de cada local. Leme e Seabra (2017) avaliaram os custos envolvidos na produção do biometano pelo tratamento anaeróbico da vinhaça, considerando as principais técnicas de enriquecimento. A Figura 12 mostra os resultados, dividindo os custos entre o processo de produção e dessulfurização grossa e o processo de upgrading. Os autores consideraram uma produção de biogás bruto de $5.020 \mathrm{~m}^{3} / \mathrm{h}$.

Na Figura 13 são apresentados dados de custos, restritos ao processo de upgrading, pelas mesmas técnicas, a partir de outra referência. Fica evidente a importância do fator escala na redução dos custos específicos, ou seja, por quantidade de biometano produzido.

Figura 12. Custos da produção de biometano a partir da vinhaça, dividido em upgrading e produção do biogás

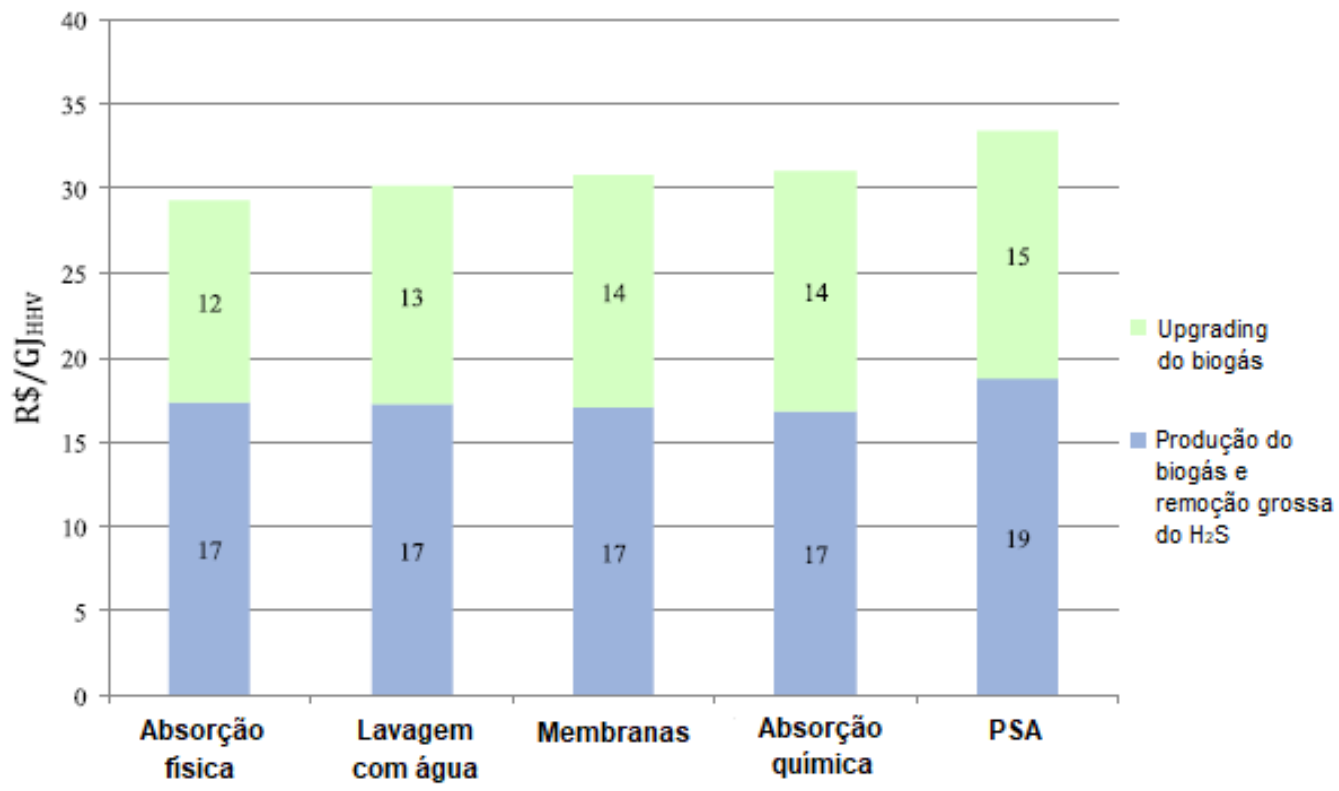

Fonte: adaptado de Leme e Seabra (2017). 
Figura 13. Custos específicos de upgrading do biogás, em dólares por $\mathrm{m}^{3}$ de metano

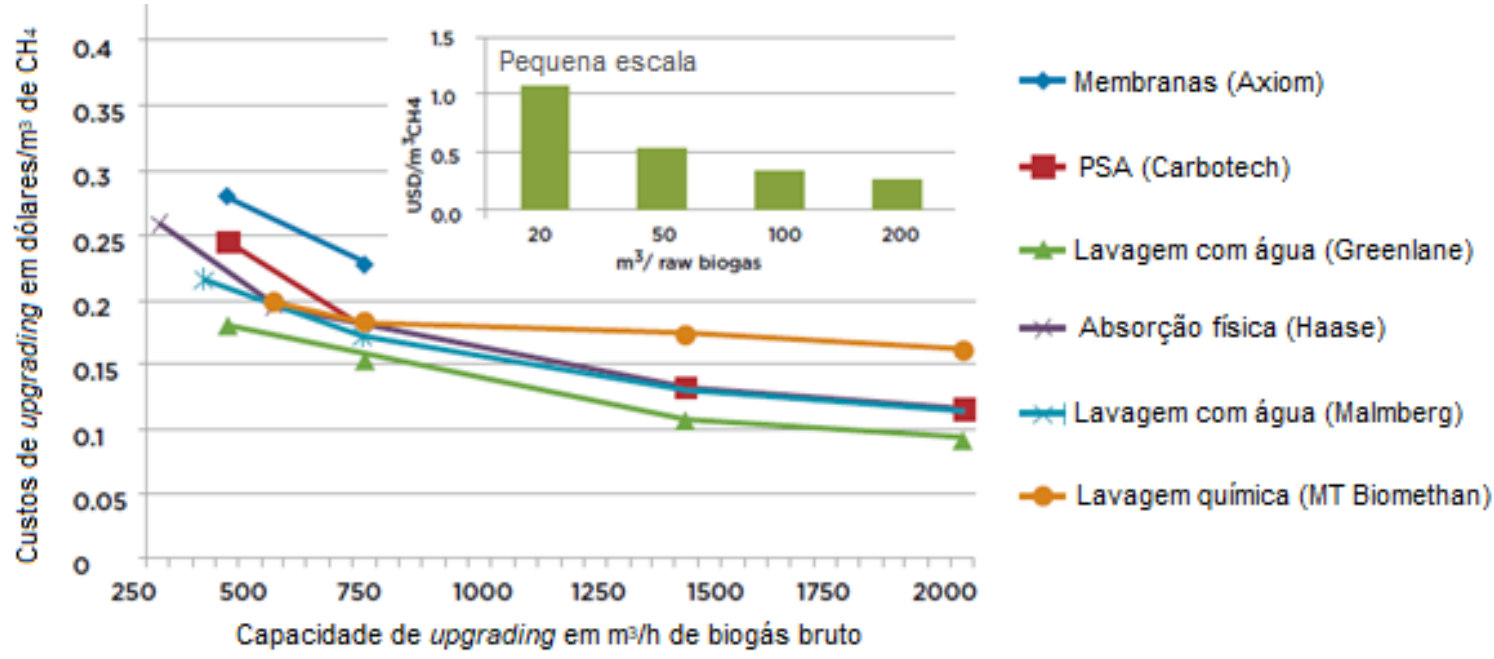

Fonte: adaptado de Adler et al. ${ }^{7}$ (2014) apud IRENA (2017).

Leme e Seabra (2017) avaliaram os custos em reais e em GJ, baseado no poder calorífico superior (PCS, ou HHV, do inglês high heating value) do metano, enquanto na Figura 13 os dados estão em dólares e metros cúbicos. Para facilitar a comparação dos dados, pode-se transformar as unidades da Figura 12, por exemplo, para a técnica de lavagem com água.

O valor de $\mathrm{R} \$ 30 / \mathrm{MJ}_{\mathrm{HHV}}$ (referente ao custo total do biometano - incluindo a produção do biogás - no processo de lavagem com água na Figura 12) corresponde a cerca de $R \$ 1,20 / \mathrm{m}^{3}$ de metano, ou cerca de US $\$ 0,38 / \mathrm{m}^{3}$ - no câmbio ${ }^{8}$ de $\mathrm{R} \$ 3,12$ para US $\$ 1,00$ e considerando o PCS do metano igual a 39,7 MJ/m³ (PERRY; CHILTON, 1986). Da mesma forma, o valor de $\mathrm{R} \$ 13 / \mathrm{MJ}_{\mathrm{HHV}}$ (referente ao custo apenas do upgrading para a lavagem com água) corresponde a cerca de $\mathrm{R} \$ 0,52 / \mathrm{m}^{3}$, ou US\$0,17/ $\mathrm{m}^{3}$. Mesmo a escala avaliada em Leme e Seabra (2017) superando a maior escala mostrada na Figura 13, os custos apresentados são maiores - ainda que compatíveis.

Patterson et al. (2011) também apresenta dados similares, reunindo dados de estudos de 2007 a 2009. O menor valor, apenas para o upgrading, é de $€ 0,11 / \mathrm{m}^{3}$ (equivalente a cerca de R\$ 0,41 ou US\$ 0,13), para PSA e lavagem com água.

\footnotetext{
${ }^{7}$ Adler,P., Billig, E., Brosowski, A., Daniel-Gromke, J., Falke, I., Fischer, E., Grope, J., Holzhammer, U., Postel, J., Schnutenhaus, J., Stecher, K., Szomszed, G., Trommler, M., Urban, W. (2014): Leitfaden Biogasaufbereitung und -einspeisung, Fachagentur Nachwachsende Rohstoffe e.V. (FNR), Gülzow-Prüzen

${ }^{8}$ Câmbio comercial de 04 de agosto de 2017 (BANCO CENTRAL DO BRASIL, 2017)
} 
Os dados e avaliações mostram que os custos típicos das principais técnicas são similares entre si, e podem ter variações de acordo com a referência e com as características de cada local. Leme e Seabra (2017), verificando a proximidade dos custos, avaliam que outros critérios podem influenciar a decisão: a disponibilidade de fornecedores locais, esforços operacionais e de manutenção, riscos ambientais e para a saúde, e até preferência pessoal. Nesses casos, para os autores, podem ser considerados vantajosos os processos PSA e lavagem com água, pela simplicidade de operação devido à inexistência de meio líquido e pela disponibilidade da água em relação aos outros solventes, respectivamente. 


\section{DIRECIONAMENTO DA UTILIZAÇÃO E EXPERIÊNCIA INTERNACIONAL}

A Seção 3 apresentou diversas maneiras de se utilizar o biogás. A Tabela 4 resume as opções de utilização, com as respectivas entradas e objetivos esperados.

Tabela 4 - Resumo das opções de utilização do biogás avaliadas

\begin{tabular}{|c|c|c|}
\hline Opção/Estratégia & Entrada/Input & Objetivo/Output \\
\hline $\begin{array}{c}\text { Queima direta sem } \\
\text { aproveitamento energético }\end{array}$ & Biogás bruto & $\begin{array}{c}\text { Redução de emissões de gases de } \\
\text { efeito estufa }^{[1]}\end{array}$ \\
\hline $\begin{array}{c}\text { Aproveitamento energético do } \\
\text { biogás }\end{array}$ & $\begin{array}{c}\text { Biogás bruto ou } \\
\text { pós-limpeza }\end{array}$ & $\begin{array}{c}\text { Energia térmica } \\
\text { Epgrading do biogás }\end{array}$ \\
\cline { 2 - 3 } & Biogás bruto & Energia elétrica \\
\hline
\end{tabular}

[1]: Esse objetivo é atingido em todas as opções de utilização do biogás por meio da captura e combustão do metano.

Fonte: elaboração do autor.

A obtenção de energia térmica por meio da queima do biogás é uma opção que depende de uma característica: deve haver uma demanda por calor em locais muito próximos à geração do biogás. Portanto, é limitada a certos casos, ainda mais em um país tropical. No entanto, na existência dessa demanda, a utilização do biogás pode ser benéfica ambiental e economicamente ao substituir outros combustíveis, como lenha e fósseis.

A geração de energia elétrica e a produção do biometano são opções universais de como aproveitar o biogás, salvo restrições específicas. Isso porque são alternativas capazes de disponibilizar a energia do biogás para o setor energético, por gerarem produtos comercializáveis.

Há restrições para a geração de energia elétrica, como ausência de infraestrutura de transmissão/distribuição, e para a geração do biometano, como inviabilidade do processo de enriquecimento, falta de infraestrutura para armazenamento e/ou transporte do gás. Porém, em princípio, pode-se tratar as duas opções como concorrentes.

Como consequência do que já foi apresentado, neste trabalho se considerou, como base para a comparação entre geração de energia elétrica e produção de biometano a partir do biogás, que: 
- São duas opções concorrentes pelo mesmo potencial energético, limitado especialmente se considerado apenas o economicamente viável;

- Ambas podem ter seus produtos comercializados e inseridos no setor energético;

- As alternativas são distintas na forma que se fazem disponíveis e se enquadram em mercados diferentes no setor energético.

A lógica de tratar essas duas alternativas de utilização de biogás como concorrentes já foi aplicada em outros estudos. Na Seção 4.1, será apresentada uma revisão bibliográfica de trabalhos nesse sentido, e que as comparam de diversas maneiras.

\subsection{Energia Elétrica x Biometano - revisão bibliográfica}

A ideia da comparação entre produção de energia elétrica e de biometano não é original. No entanto, não foram encontrados trabalhos com o foco de analisar a questão como uma decisão estratégica do Estado com diversas dimensões, como é o objetivo desta dissertação. Nesta Seção é apresentada uma revisão de trabalhos que comparam, de diversas formas, estratégias de aproveitamento do biogás. Os trabalhos foram agrupados e são apresentados de acordo com o objeto da comparação, selecionados de acordo com o entendimento deste autor, iniciando pelos trabalhos com foco econômico, seguido pelos com foco ambiental e, por fim, pelos que analisam ambos, como mostra a Tabela 5.

Tabela 5 - Identificação dos focos das análises realizadas nos trabalhos da revisão bibliográfica sobre energia elétrica versus biometano

\begin{tabular}{|l|c|c|c|}
\hline Referência & Econômico & Ambiental & Outros focos \\
\hline $\begin{array}{l}\text { Budzianowski e Budzianowska } \\
(2015)\end{array}$ & $\mathrm{X}$ & & \begin{tabular}{c} 
Incentivos \\
\hline Goulding e Power (2013)
\end{tabular} \\
\hline Jardim (2013) & $\mathrm{X}$ & & $\begin{array}{c}\text { Potencial energético } \\
\text { (Irlanda) }\end{array}$ \\
\hline Patrizio et al. (2015) & $\mathrm{X}$ & $\mathrm{T}$ Tecnológica; \\
\hline Carnavale e Lombardi (2015) & & $\mathrm{X}$ & Localização das plantas \\
\hline Ravina e Genon (2015) & $\mathrm{X}$ & $\mathrm{X}$ & \\
\hline Mills, Pearce e Thorpe (2013) & $\mathrm{X}$ & $\mathrm{X}$ & \\
\hline $\begin{array}{l}\text { Murphy, McKeogh e Kiely } \\
(2004)\end{array}$ & $\mathrm{X}$ & $\mathrm{X}$ & Eficiência energética \\
\hline Wu et al. (2016) & & & \\
\hline
\end{tabular}

Fonte: elaborado a partir das referências citadas. 
Budzianowski e Budzianowska (2015) avaliaram a viabilidade econômica de projetos de geração de energia com biogás sob diferentes instrumentos de incentivo, comparando as alternativas de cogeração e produção de biometano. Como resultado, mostraram que, para promover a produção de biometano, o incentivo (por kWh) necessário foi mais que $50 \%$ menor que o necessário para a eletricidade gerada em unidades de cogeração com biogás (BUDZIANOWSKI; BUDZIANOWSKA, 2015).

Avaliando a Irlanda como um país em que a produção de biogás ainda está em desenvolvimento, Goulding e Power (2013) buscaram a melhor opção no país para a utilização desse potencial energético. As opções de uso consideradas foram a cogeração e a produção de biometano como combustível para transporte, e a comparação foi feita com base nas análises econômicas do processo, considerando a tarifa incentivada de eletricidade do biogás e uma tarifa estimada para o biometano, mais barata por unidade de energia que diesel e gasolina. $\mathrm{O}$ resultado foi que o biometano como combustível de transporte seria a solução ótima para o biogás no país, por sua atratividade em relação aos combustíveis que substitui e porque a cogeração é prejudicada pela falta de um mercado para a energia térmica. Os autores também mostraram a alta sensibilidade da competitividade em relação à escala das plantas e à tarifa de venda do biometano (GOULDING; POWER, 2013).

Jardim (2013) realizou, em sua tese de mestrado intitulada "Valorização Económica do Biogás: Geração Elétrica vs. Produção de Biometano para Injeção na Rede”, um estudo técnicoeconômico sobre a produção de biometano. Foi analisado o contexto para a produção deste biocombustível na Europa e em Portugal, país em que o trabalho foi realizado e no qual, então, inexistiam plantas de produção de biometano. O trabalho calculou resultados econômicos da produção de biometano estimando a remuneração para injeção na rede baseado no preço do gás natural e em um preço para o carbono. Estes resultados foram comparados com os custos e a tarifa de venda de energia elétrica de uma planta real. Os resultados mostraram custos de investimentos e receita operacional mais vantajosas para a opção de produção do biometano. $\mathrm{O}$ autor concluiu que o biometano poderia ser competitivo em Portugal, e sugeriu políticas para o desenvolvimento dessa alternativa no país (JARDIM, 2013).

Para o caso específico do norte da Itália, Patrizio et al. (2015) investigaram a competitividade das opções de cogeração e de produção de biometano a partir do biogás. Os autores consideraram o tema relevante por ser uma região com grande produção de biogás e com rede de gás natural disponível. Como resultado, o trabalho calculou um imposto sobre o carbono que tornaria as opções competitivas em seus respectivos mercados; o menor valor seria 
para a opção de cogeração, que tem a ela atribuída a maior vantagem ambiental. Além de um alto imposto sobre o carbono, o desenvolvimento do biometano poderia se beneficiar de níveis mais elevados dos preços de gás natural ou incentivos direcionados (PATRIZIO et al., 2015).

Carnevale e Lombardi (2015) acrescentaram à cogeração usando motores a combustão interna e à produção de biometano a opção de uso de células a combustível para produção de eletricidade e calor. Para essas três alternativas, os autores avaliaram o impacto ambiental com a ferramenta da análise de ciclo de vida. Os resultados mostraram o maior benefício no uso de células a combustível, seguido de motores e da produção de biometano substituindo gás natural, sendo esta última prejudicada pelo consumo de energia no tratamento do biogás, pelo tratamento de rejeitos do processo e pelas perdas de metano. No entanto, as diferenças foram minimizadas em casos em que não houve o aproveitamento da energia térmica da cogeração, seja gerado nas células a combustível ou nos motores. Os autores também apontaram que, independente do cenário, a redução de emissões de gases de efeito estufa são "muito importantes” ao usar biogás para gerar energia (CARNEVALE; LOMBARDI, 2015).

Ravina e Genon (2015) compararam, em termos de emissões globais e locais, a cogeração de energia elétrica e calor com a produção de biometano nos cenários de injeção na rede e de uso no setor de transportes. Foi avaliado que, nos casos em que não há aproveitamento da energia térmica da cogeração, o biometano pode representar uma alternativa mais sustentável; no entanto, perdas significativas de metano para a atmosfera no processo de tratamento do biogás podem comprometer seu resultado em termos de emissões de GEE (RAVINA; GENON, 2015).

Trabalhando no contexto britânico de incentivos para energia térmica renovável, Mills, Pearce e Thorpe (2013) consideraram o ciclo de vida ambiental e econômico para comparar a cogeração com a produção de biometano. Segundo os autores, apesar de a indústria estar considerando a instalação de plantas de limpeza e enriquecimento para injeção na rede, esta alternativa é considerada muito dependente dos incentivos para a viabilidade econômica; a geração de eletricidade, por outro lado, seria menos dependente. Além disso, a injeção de biometano traria menos benefícios ambientais. As conclusões do trabalho apontaram para o questionamento dos incentivos ao biometano e para os riscos de mudança nessa política (MILLS; PEARCE; THORPE, 2013).

Murphy, McKeogh e Kiely (2004) compararam, para as condições da Irlanda, a cogeração com a produção de biometano como combustível para transporte. Os autores traçaram diferentes cenários para o caso do biometano, variando o combustível a ser substituído - 
gasolina e diesel - e a origem da eletricidade utilizada no processo - da rede ou produzida com parte do biogás da planta. O melhor resultado encontrado, em termos econômicos e de emissões de GEE nas circunstâncias avaliadas, foi a produção de biometano com o consumo interno de eletricidade suprido com biogás próprio, apesar da redução da quantidade do produto (MURPHY; MCKEOGH; KIELY, 2004).

Wu et al. (2016), além da produção de eletricidade em uma unidade de cogeração e a produção do biometano, compararam também a alternativa de uso em uma célula a combustível de óxido sólido. O trabalho avaliou os desempenhos energético, econômico e ambiental de um sistema de biogás com essas três alternativas. Os resultados foram apresentados na forma de índices. Na eficiência energética e no tempo de payback, a produção de biometano teve os melhores resultados; sob o ponto de vista ambiental, no entanto, os piores valores foram atribuídos a esta alternativa, devido ao consumo de eletricidade externa e a perda de metano (WU et al., 2016).

Foram apresentados, na Seção 4.1, estudos comparando as duas formas de energia produzidas a partir do biogás. A análise dos focos das comparações revela a diversidade de aspectos que diferenciam as duas alternativas, principalmente os econômicos e ambientais; a análise dos trabalhos completos mostra, também, a diversidade de fatores que podem influenciar os resultados.

\section{2 "Uso prioritário" para a energia do biogás}

A diversidade de usos do biogás, representada pelas opções de geração de eletricidade e produção de biometano, tem como consequências a flexibilidade que confere ao produtor, que pode optar por diferentes alternativas de comercializar sua energia, e a alternativa que oferece ao setor energético como um todo, pois a energia do biogás pode ser aproveitada de maneiras distintas, cada uma com suas características e consequências econômicas e ambientais, por exemplo.

A opção por uma utilização para o biogás tende a ser definida de acordo com dois interesses que podem não ser convergentes: o do produtor, que visa a maximização de seus lucros; e o comum ou coletivo, que deve ser buscado pelos formadores de políticas públicas (WHITE et al., 2013).

Os trabalhos que fazem a análise econômica mostram que os lucros do produtor dependem de fatores como: custos de investimento e de produção da energia elétrica e do 
biometano, incluindo levar o produto até a rede de transmissão/distribuição de energia elétrica ou até a rede de gás natural; volume de produção de cada bem; e seus preços de venda. Ainda, a decisão sobre o investimento está associada aos mecanismos de comercialização, aos incentivos financeiros, e aos riscos e, portanto, à segurança oferecida ao produtor da eletricidade ou do biometano. As diretrizes da política energética, e os instrumentos utilizados para sua operacionalização, exercem grande influência em cada um desses fatores e, assim, pode tornar convergentes os interesses do produtor e o coletivo.

Nesta dissertação, identificou-se a distinção entre os mercados em que se inserem a energia elétrica e o biometano produzidos a partir do biogás. As variadas formas de utilização do biogás têm muitas características que as diferenciam, entre elas as tecnologias e o contexto do mercado em que se inserem e as fontes de energias que são capazes de substituir; consequentemente, também são diferentes em aspectos ambientais, econômicos, entre outros.

Sabendo que são distintas em diversos aspectos, considera-se que pode haver uma forma com mais benefícios no contexto do setor energético. Ou seja, é possível que, especialmente entre as opções de produção de energia elétrica e de biometano, haja uma alternativa de utilização mais vantajosa para o biogás.

Ravina e Genon (2015, p. 124, tradução nossa), afirmaram que "uma discussão coordenada dos aspectos econômicos, ambientais e de planejamento ligados aos diferentes esquemas de utilização de biogás parecem ser necessários para as autoridades públicas, como forma de chegar à solução final e ótima”.

Portanto, uma análise abrangente, envolvendo diversos critérios, seria relevante para identificar os benefícios e desvantagens de cada uso. Essa identificação pode, então, servir como base para a formulação de políticas de incentivos de longo prazo para, de maneira proposital, direcionar a utilização do biogás de forma adequada à política e ao planejamento energético - a este uso, escolhido para ser incentivado, neste trabalho se optou por chamar de "uso prioritário".

Não se deve ignorar a flexibilidade característica do biogás e a especificidade de cada empreendimento; no entanto, estimular uma opção de uso pode ser benéfico ao setor energético e ao país por poder contribuir, da melhor maneira, em aspectos econômicos e ambientais, entre outros, como demonstrado em outros trabalhos na Seção 4.1, e como se pretende avaliar nesta dissertação na Seção 5, para o caso brasileiro. 
Há, ainda, outras questões que corroboram com o argumento de que pode ser importante a comparação das duas alternativas e a avaliação de um uso prioritário. Em primeiro lugar, conforme apresentado na Seção 1, há diversas barreiras ao desenvolvimento do setor de biogás que poderiam ter essa estratégia como parte da solução.

Entre eles, o fato de existirem políticas de incentivo para o desenvolvimento das energias renováveis, incluindo a bioenergia e o biogás, que têm sido empregadas como forma de alcançar uma transição para um setor energético de baixo carbono. Segundo White et al. (2013), as políticas de incentivo direcionadas ao setor de bioenergia devem ter visão estratégica e objetivos claros; para atingi-los, devem ser desenvolvidos incentivos financeiros concretos e contínuos no longo prazo, como o fator mais importante (IEA BIOENERGY, 2009). A consistência da política e a continuidade dos incentivos são importantes para os investimentos (WHITE et al., 2013).

Portanto, os incentivos financeiros devem estimular comportamentos que reflitam a visão e os objetivos da política, de maneira que possam ter continuidade. Esse conjunto deve ser planejado de forma harmônica com os interesses do setor energético e outros setores envolvidos na questão. A existência de incentivos torna ainda mais importante a visão governamental sobre o setor, pois tendem a direcionar sua evolução na direção dos comportamentos incentivados.

Caso não haja planejamento, o mercado pode ser direcionado de maneira "nãointencional". Os incentivos existentes em cada mercado e as condições pré-estabelecidas podem favorecer um uso em detrimento de outro, mesmo que sem este objetivo. A presença de incentivos gerais para energias renováveis em apenas um dos setores, por exemplo, pode deslocar o mercado e favorecer uma forma de utilização. Ainda, os mecanismos de comercialização de energia existentes e a compreensão dos reguladores pode remover barreiras e abrir caminhos em um dos mercados de forma distinta ao outro.

Segundo Budzianowski e Budzianowska (2015), na Europa, de forma geral, altos subsídios para a geração de eletricidade distorcem a direção do desenvolvimento tecnológico do biogás, que é forçado para unidades de cogeração. Em muitos casos, esses incentivos não são desenhados apenas para o biogás, mas para fontes do setor elétrico como um todo. Por outro lado, são raros os incentivos econômicos para a produção de biometano, mas essa alternativa, recentemente, vem recebendo mais atenção. A situação dos incentivos no Brasil será avaliada na Seção 6. 
Assim, nota-se que condições não desenhadas para esse propósito podem deslocar a utilização de biogás em direção a um caminho, seja de produção de energia elétrica ou de biometano. Considera-se, como premissa deste trabalho, que esta não é a melhor maneira de proceder o desenvolvimento do setor de biogás; ou seja, não é o ideal que, por meio de incentivos sem planejamento focado no setor, ou pela existência de barreiras regulatórias ou comerciais, se decida como aproveitar o limitado, e possivelmente valioso, potencial energético do biogás.

Cabe ressaltar que, apesar de a Seção 6 avaliar incentivos financeiros vigentes e barreiras regulatórias de cada utilização no Brasil, não faz parte dos objetivos deste trabalho determinar se há um uso sendo favorecido. No entanto, considera-se absolutamente relevante, como complementação de uma contribuição futura, que sejam identificados e constatado se há, atualmente, um direcionamento de mercado para alguma das estratégias. Então, baseado no planejamento, seria possível redirecioná-los, ou reformulá-los visando a igualdade de condições para que, então, as decisões de cada empreendimento sejam tomadas com o mínimo de influência da política.

Assim, ter um uso que catalise as iniciativas do biogás em um formato pode levar a outras consequências positivas - e ajudar o setor a superar algumas das barreiras ao seu desenvolvimento, apresentadas na Seção 1 -, entre elas:

- Acelerar a curva de aprendizado das tecnologias relacionadas a este uso e, consequentemente, levar a processos mais eficientes;

- Economia de escala nos equipamentos e matérias-primas de processo e desenvolvimento de indústria nacional;

- Definição do espaço no setor energético definindo responsabilidade aos agentes e trabalho de um setor dedicado ao biogás;

- Incentivos mais claros e direcionados, com proposta de manutenção por longo prazo.

Por outro lado, há desvantagens na abordagem do "uso prioritário". Obviamente, um dos usos teria seu desenvolvimento prejudicado, pois seria preterido. Ainda, um planejamento imperfeito ou mudanças de rumo no setor energético podem fazer com que o esforço de identificação de um uso prioritário, e os incentivos direcionados, sejam considerados, no futuro, errados. Esse é um dos riscos do direcionamento do mercado, e um dos motivos para intervenções políticas nem sempre serem bem recebidas; tal questão será analisada de forma mais aprofundada na Seção 4.3. 


\subsection{Escolha pelo mercado versus intervenção do Estado}

Esta seção tem como objetivo apresentar e desenvolver a principal crítica para a identificação e escolha de um uso prioritário do biogás, que é uma das propostas deste trabalho. Serão apresentados também contra-argumentos. Consequentemente, espera-se confirmar a relevância do tema e fortalecer a análise ao adicionar complexidade e abordar mais um de seus aspectos.

A premissa deste trabalho é que há duas alternativas principais para a disponibilização da energia do biogás para o setor energético, e que as características de cada alternativa, o contexto e o mercado em que se inserem são diferentes. Portanto, pode haver uma opção de utilização mais interessante para o biogás no Brasil, e pode ser possível identificá-la analisando uma série de critérios.

Esta ideia, motivadora da elaboração do projeto e que norteia o trabalho, pode ser criticada no sentido de que, se houver uma opção mais interessante, não cabe ao formulador de políticas - ou, no caso, a este trabalho acadêmico - apontá-la, e sim ao mercado. Assim, independentemente das análises realizadas e do resultado encontrado, a intervenção em favor de uma das alternativas seria indesejada. A única comparação relevante, portanto, seria a análise de viabilidade econômica de cada empreendimento, exclusiva por suas diferentes condições, como vazão e composição do biogás, disponibilidade de infraestrutura e custos da ligação à rede, preço da energia elétrica, entre outros.

\subsubsection{Crítica à intervenção: "escolhendo vencedores"}

A crítica a uma possível escolha de um uso prioritário se baseia na defesa de uma economia de mercado, em que o preço é o mecanismo da "mão invisível” para conduzir a atividade econômica, maximizando o bem-estar da sociedade. Para isso, a intervenção do governo na economia é indesejada, a não ser em casos específicos, como na presença de externalidades, comuns no setor energético. Mesmo assim, são preferíveis políticas "baseadas no mercado", como a introdução de um imposto corretivo, que deve ser atribuído corretamente para deslocar a alocação de recursos para mais perto do ótimo social (MANKIW, 2016).

A defesa da economia de mercado e da não intervenção governamental também é comum direcionada ao setor energético, especialmente como crítica a políticas que tem emergido como resposta às mudanças climáticas. 
A revista The Economist, por exemplo, em reportagem de 2010 sobre o "renascimento global da política industrial", aponta que o setor de tecnologias limpas tem recebido altos investimentos públicos na esperança da criação de empregos e da redução de emissões. Um dos grandes problemas dessas políticas, segundo a revista, é que estariam "escolhendo vencedores" e "salvando perdedores", com o favorecimento de setores e companhias específicos. James Manyika, então diretor do McKinsey Global Institute, é citado dizendo que "escolher vencedores em tecnologias limpas é um erro como era em indústrias antigas" (THE ECONOMIST, 2010).

Em artigo de opinião no Financial Times, o professor de política energética da Universidade de Oxford, Dieter Helm, defende argumentos similares. Criticando a estratégia do Reino Unido no setor de energia, diz que o governo tem escolhido vencedores - e errado. Ele estende sua crítica (HELM, 2014, tradução nossa):

Em se tratando de política energética, os políticos sempre pensam que sabem as respostas - e deixam os consumidores pagando o preço por anos após saírem do cargo. A lição é dolorosamente óbvia: a matriz energética deve ser o resultado de processos de mercado, não o objetivo de política governamental.

Os artigos da The Economist (2010) e de Helm (2014) fazem referência a estipular um preço (imposto) sobre o carbono como forma de reduzir emissões, mantendo a competição entre as tecnologias no mercado, ou seja, sem direcioná-lo. Na Seção 4.3.2, será mostrado que não há unanimidade na classificação desse imposto como sendo uma política absolutamente "neutra", e muito menos como a única política correta a ser adotada no setor energético.

\subsubsection{Neutralidade tecnológica e defesa do apoio direcionado}

Do outro lado, diversos trabalhos apontam para a dificuldade de garantir neutralidade, em relação às tecnologias, das políticas destinadas à redução das emissões de gases de efeito estufa. Indo além, alguns argumentam que o apoio direcionado pode ser desejável e até necessário frente ao desafio representado pelas mudanças climáticas.

Neste debate, Azar e Sandén (2011, p. 135, tradução nossa) reconhecem que constantemente é dito que "governos não são bons escolhendo vencedores; isso deveria ser deixado ao mercado". Um "mantra recorrente" seria a "neutralidade tecnológica"; políticas com este objetivo seriam as que promovem tecnologias com nenhuma ou com baixas emissões de 
carbono sem especificar quais serão apoiadas. No entanto, segundo eles, o objetivo da neutralidade tecnológica "geralmente é ilusório e não pode nem deveria ser priorizado como o princípio orientador das políticas".

Apesar de tratarem a valoração do carbono como a "espinha dorsal de qualquer política de sucesso e custo-efetiva visando a redução de emissões”, Azar e Sandén (2011, p. 136, tradução nossa) criticam a noção de que esta é, como apontado por alguns de seus defensores, uma medida neutra. Eles alegam que, em um cenário em que haja um imposto sobre o carbono, algumas tecnologias que se tornariam viáveis podem ter outras consequências indesejáveis. Entre elas, a expansão em grande escala da bioenergia - e os possíveis impactos decorrentes dessa atividade, como aumento do desmatamento - e da energia nuclear - e sua relação com a proliferação de armas nucleares.

Portanto, "invocar a neutralidade tecnológica para evitar a discussão irá ajudar pouco em guiar a sociedade para soluções atrativas de longo prazo para o problema climático" (Azar e Sandén, 2011, p. 136, tradução nossa). Os autores ainda afirmam, sobre a propagada solução de economistas de que a solução é também internalizar os custos das outras externalidades das tecnologias:

(...) não pode ser nada mais que um sonho distante acreditar que um custo correto das externalidades pode ser estimado para tecnologias com ramificações tão extensas. Dadas as consequências em jogo, é absurdo argumentar que a escolha de nossas tecnologias energéticas básicas não precisam ser - não devem ser - uma questão política.

Nesse sentido, para Gross et al. (2012) até mesmo a definição do valor ótimo para um possível imposto sobre o carbono tende a não ser neutra, por causa da complexidade de definir as consequências do imposto. Assim, adotar um valor teórico se torna uma proposição não realista, e a escolha, consequentemente, também se torna política.

Gross et al. (2012) afirmam que, na prática, poucos países adotaram o imposto sobre o carbono. Isso ocorre porque esta alternativa sofre com diversos obstáculos para sua realização. Além da complexa definição do valor, há a dificuldade política de cobrar esse imposto. Um dos motivos é ser considerado regressivo, ou seja, "um imposto segundo o qual os contribuintes com altas rendas pagam uma fração menor de sua renda que os contribuintes com rendas menores" (MANKIW, 2016, pg. 233). Ainda, essa medida pode gerar desequilíbrios competitivos entre os países no mercado internacional, com maiores consequências se o preço do carbono for diferente. 
Além de tratarem do preço sobre o carbono, Azar e Sandén (2011) também argumentam pela impossibilidade de neutralidade em outros três tipos de política, consideradas por eles necessárias para o desenvolvimento do setor de energias limpas:

- Incentivos a pesquisa e desenvolvimento de tecnologias: cabe aos governos definirem as prioridades e alocarem os recursos;

- Incentivos para a implantação e comercialização de tecnologias: os governos devem, em alguns casos, reduzir barreiras para a entrada no mercado e permitir redução de custos pelo avanço na curva de aprendizado;

- Investimentos em infraestrutura: nos setores de energia e transporte, este tipo de investimento pode ter vida útil de meio século ou mais, e requerem apoio do setor público, de acordo com as visões de longo prazo sobre tecnologias específicas.

Estes três tipos de política também são defendidos por Gross et al. (2012). Segundo eles, o apoio direcionado pode criar mercados para as tecnologias emergentes, gerando inovação e fazendo com que elas se movam pela curva de aprendizado, ajudando a diminuir os custos para que possam ser altamente competitivas no futuro. Ao mesmo tempo, evita-se que investimentos realizados no curto prazo não restrinjam o sistema energético aos combustíveis fósseis no longo prazo, apenas devido a viabilidade atual dessa forma de energia - o chamado aprisionamento tecnológico, ou “lock-in", à infraestrutura instalada.

Na visão de Gross et al. (2012), a importância de estratégias específicas para promover tecnologias e inovação é aceita internacionalmente, enquanto "alguns economistas" argumentam que esse tipo de subsídio distorce o mercado e é prejudicial à economia. Segundo os autores, mesmo que se pratique a cobrança de imposto sobre o carbono, há diversas incertezas que tornam investimentos em tecnologias limpas mais arriscados e, portanto, com custo de capital mais alto. Assim, são importantes os incentivos direcionados, como tarifas feedin e preços fixados por longos prazos, que dão garantias ao investidor.

Outra linha de defesa dos incentivos para as energias renováveis vem dos que avaliam que as fontes maduras, para chegarem nos níveis de desenvolvimento e custos atuais, foram beneficiadas pela experiência adquirida ao longo do tempo, e por subsídios fornecidos pelo Estado (GROSS et al., 2012).

Banks e Allott (2012), com foco no caso do Reino Unido, argumentam que os governos historicamente escolheram vencedores ao financiar pesquisa e desenvolvimento e com subsídios para as indústrias de petróleo e gás natural e de energia nuclear, que foram 
beneficiadas por décadas. Ironicamente, segundo eles, os defensores da ideia de que os governos não devem "escolher vencedores", por meio apenas da adoção de um imposto sobre o carbono, são os entusiastas do gás e da nuclear. A explicação seria que, com esse imposto, estas agora maduras indústrias teriam grande desenvolvimento, principalmente substituindo o carvão como fonte de energia. Os autores criticam ainda a falta de confiabilidade e os custos além do orçamento comuns nos projetos de energia nuclear, além da possível dependência do país do gás natural, parte importado, com seus efeitos negativos na segurança do abastecimento e no clima. Enquanto isso, apontam para a necessidade de políticas estáveis para atrair investimentos em renováveis, de custos cada vez menores, e eficiência energética, estes sim com potencial para atingir as metas de emissões (BANKS; ALLOTT, 2012).

Seguindo essa lógica, Steffy (2013) acusa de "memória seletiva" agentes da indústria de energia, em especial os de petróleo e gás, que argumentam contra incentivos direcionados para energias renováveis, ao lembrar de diversos casos de subsídios que esse setor recebeu. No entanto, o autor também critica fracassos de renováveis com altos custos para a sociedade, e defende a transparência nos incentivos para que para que não se desperdice dinheiro com os "perdedores".

De fato, há resultados que corroboram com esses argumentos. Pfund e Healey (2011) realizaram um estudo detalhado dos subsídios recebidos pelo setor energético ao longo da história, dividindo por setores e comparando-os. O trabalho conclui que as renováveis ainda seriam, sob o ponto de vista histórico, pouco subsidiadas. Os autores também afirmam que os níveis de preço de energia atuais são resultado de investimento substancial dos governos em inovação e tecnologia, e que este investimento é crucial, ao longo de um período de muitos anos, para que uma tecnologia chegue à maturidade.

Portanto, mesmo em casos em que há convicção que as escolhas são neutras e feitas "pelo mercado", pode-se contestar e afirmar que, de fato, a política está envolvida. Os argumentos incluem o desequilíbrio histórico de incentivos e a simples impossibilidade de decisões puramente técnicas. Há, ainda, os que defendem a não neutralidade como a única forma de encarar os desafios impostos pelo cenário das mudanças climáticas. Segundo Azar e Sandén (2011, p. 139, tradução nossa):

Não existe uma política com neutralidade em relação às tecnologias quando o objetivo é conseguir uma transição de larga-escala do sistema energético global, e nem deveria existir. Em vez disso, a política tecnológica deveria ser 
uma preocupação aberta para todos os políticos e um tema amplamente debatido em todo órgão legislativo.

A necessidade de debate amplo e aberto encontra respaldo em uma preocupação dos próprios defensores da neutralidade: argumenta-se que a intervenção do governo no mercado "escolhendo vencedores" pode ser distorcida do ótimo técnico por sofrer com a influência dos grupos de pressão. Müller-Monteiro (2007), por exemplo, identifica, só no setor elétrico brasileiro, 16 grupos ou instituições com força política, que podem potencialmente intervir nas decisões. Entre elas, empresas estatais, empresas privadas, associações de classe, fornecedores de equipamentos e órgãos ambientais. Para Azar e Sandén (2011, p. 138, tradução nossa): “justamente porque há tantos grupos fazendo pressão por sua própria tecnologia, é importante que os acadêmicos não se escondam atrás dos pedidos por neutralidade, mas pensem sobre quando e como fornecer apoio direcionado para tecnologias".

Assim, estudos comparando tecnologias e que possam colaborar com políticas direcionadas no desenvolvimento do setor energético, como é o caso deste trabalho, podem ser importantes. Para minimizar os problemas, são necessários clareza nas diretrizes e nos objetivos, que devem ser baseados em análises técnicas do setor, e transparência na implementação e revisão dos instrumentos, para que seja possível acompanhar quais e quanto as tecnologias foram "escolhidas".

Mesmo não havendo um uso prioritário, ou seja, se o entendimento da política for de nivelar os incentivos para que o uso nos empreendimentos seja apenas definido "pelo mercado", é importante que haja clareza nos instrumentos de incentivo. Dessa forma, evita-se que o mercado seja direcionado por incentivos escondidos e diferentes em cada mercado, ou por outros tipos de barreiras, fatores que dificultam a comparação entre as alternativas.

Portanto, a transparência é fundamental. A clareza pode evitar que indústrias com lobby mais forte ganhem, sem conhecimento geral, a disputa por recursos e incentivos. Ainda, podese mostrar para a sociedade os objetivos das políticas, seja mudar o business as usual, incentivar apenas indústrias não maduras ou evitar tecnologias com externalidades negativas muito relevantes. Não se pode, especialmente na academia, se furtar de discutir questões como essa.

No caso do biogás, é importante que fique clara a estratégia de desenvolvimento dessa indústria. São duas tecnologias que competem diretamente pela mesma fonte, e podem haver incentivos de diversos lados, sejam eles financeiros, regulatórios, ou simplesmente por 
estruturas institucionais desenvolvidas para remover diversos tipos de barreiras que podem direcionar a indústria para um caminho.

\subsection{Experiência internacional}

Nesta seção, a experiência internacional será avaliada com foco na utilização do biogás. Entre os objetivos, pretende-se verificar de que maneira o mundo explora esse potencial energético, e identificar casos em que possa haver direcionamento da tecnologia pelas políticas públicas.

Os cinco países que mais consomem biogás estão localizados em três continentes: Ásia, América do Norte e Europa. Segundo IRENA (2017), a China é o país com o maior aproveitamento em termos de energia, que é predominantemente utilizada como energia térmica. A Figura 14 apresenta a utilização do biogás nos países com a maior produção de biogás em 2013.

Figura 14. Uso do biogás nos países com a maior produção em 2013

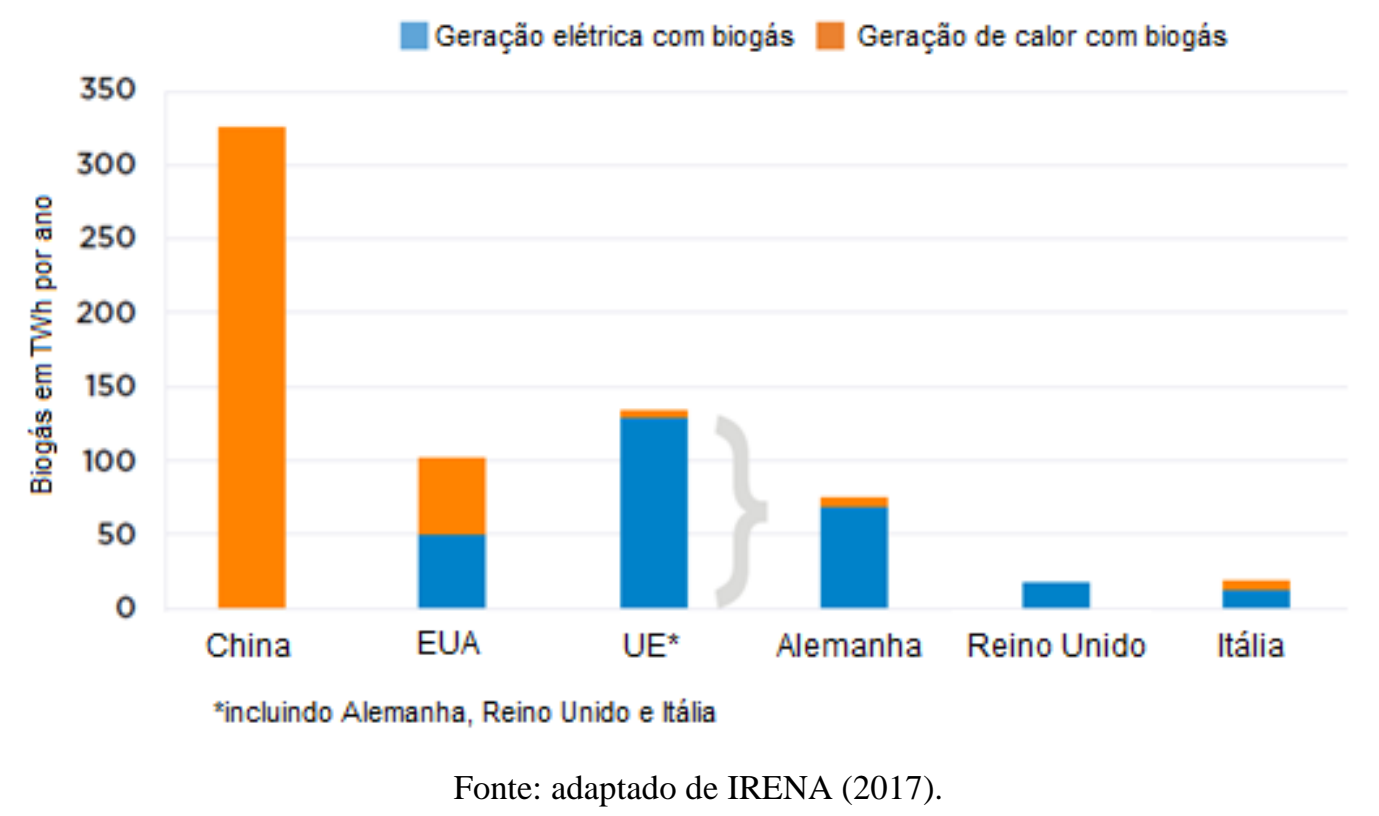

A China é um caso específico por ser o país mais populoso do mundo e pelas características da sua produção de biogás. A partir do ano 2000, iniciou-se no país um boom de construção de plantas domésticas, de pequeno porte, seguindo políticas e estratégias nacionais que buscavam melhorar o padrão de vida e reduzir a poluição ambiental causada pelo uso de energia na zona rural. A China conseguiu desenvolver tecnologia para a construção de 
digestores padronizados e de alta eficiência para esse propósito. Em 2014, havia 41,8 milhões de digestores domésticos rurais na China (CHEN; LIU, 2017), e 42,6 milhões em 2016, contra 4,7 milhões na Índia (REN 21, 2017). O biogás produzido é majoritariamente usado para a geração de calor para cocção, característica típica da produção descentralizada (CHEN; LIU, 2017).

Com transformações econômicas e sociais, como a urbanização acelerada e o aumento da escala da agricultura no país, por exemplo, o estímulo do governo passou a ser direcionado, recentemente, para plantas de biogás centralizadas, de maior porte. O setor de biogás chinês, que é coordenado pelo governo e seus mecanismos de financiamento, passou a ter cada vez mais como estratégia o desenvolvimento de projetos para contribuir com o suprimento de gás natural e geração de energia elétrica. Surgiu também o conceito de "biogás industrial", de produção e tratamento em larga escala para facilitar o transporte e o uso final, e foram desenvolvidas políticas para a criação de uma cadeia industrial para o setor (CHEN; LIU, 2017).

Nos Estados Unidos, a produção de biogás está concentrada na captura de gás de aterro (REN 21, 2017), com 652 unidades (ABC, 2016), e em estações de tratamento de esgoto, com mais de 1270 plantas. Há produção também em cerca de 250 fazendas agropecuárias e em cerca de 100 unidades que usam como matéria-prima resíduos da indústria e do consumo de alimentos (EPA, 2015). Nas ETEs, a maior parte da energia aproveitada é consumida em unidades de cogeração (SHEN et al., 2015).

Segundo NREL (2013), é estimado que o potencial de produção de metano pelo biogás no país seria capaz de suprir, por exemplo, 56\% do gás natural utilizado no setor de transportes. No entanto, de acordo com USDA (2014), as políticas estaduais são diferentes entre si, e as inconsistências entre estas e as federais são apontadas como barreiras para o desenvolvimento desse potencial. Mesmo sendo apontado como um dos principais produtores de biogás no mundo, a literatura encontrada sobre o sistema de produção e utilização de biogás nos Estados Unidos foi relativamente escassa.

A União Europeia também não apresenta um sistema coeso entre seus países membros. As diferenças se apresentam em todos os aspectos, como o volume de produção de biogás, as principais matérias-primas usadas na produção, e a forma de utilização predominante. As estratégias para o setor são, portanto, distintas.

Na Alemanha, a agricultura é a principal fonte de geração de biogás. No Reino Unido, segundo principal produtor, o gás de aterro compõe mais de $80 \%$ do total, enquanto na Suécia 
mais da metade é proveniente de estações de tratamento de esgoto. A Figura 15 apresenta a participação das matérias-primas nos principais países produtores de biogás da Europa.

Figura 15. Participação das fontes e produção total de biogás em países selecionados da Europa, em 2013

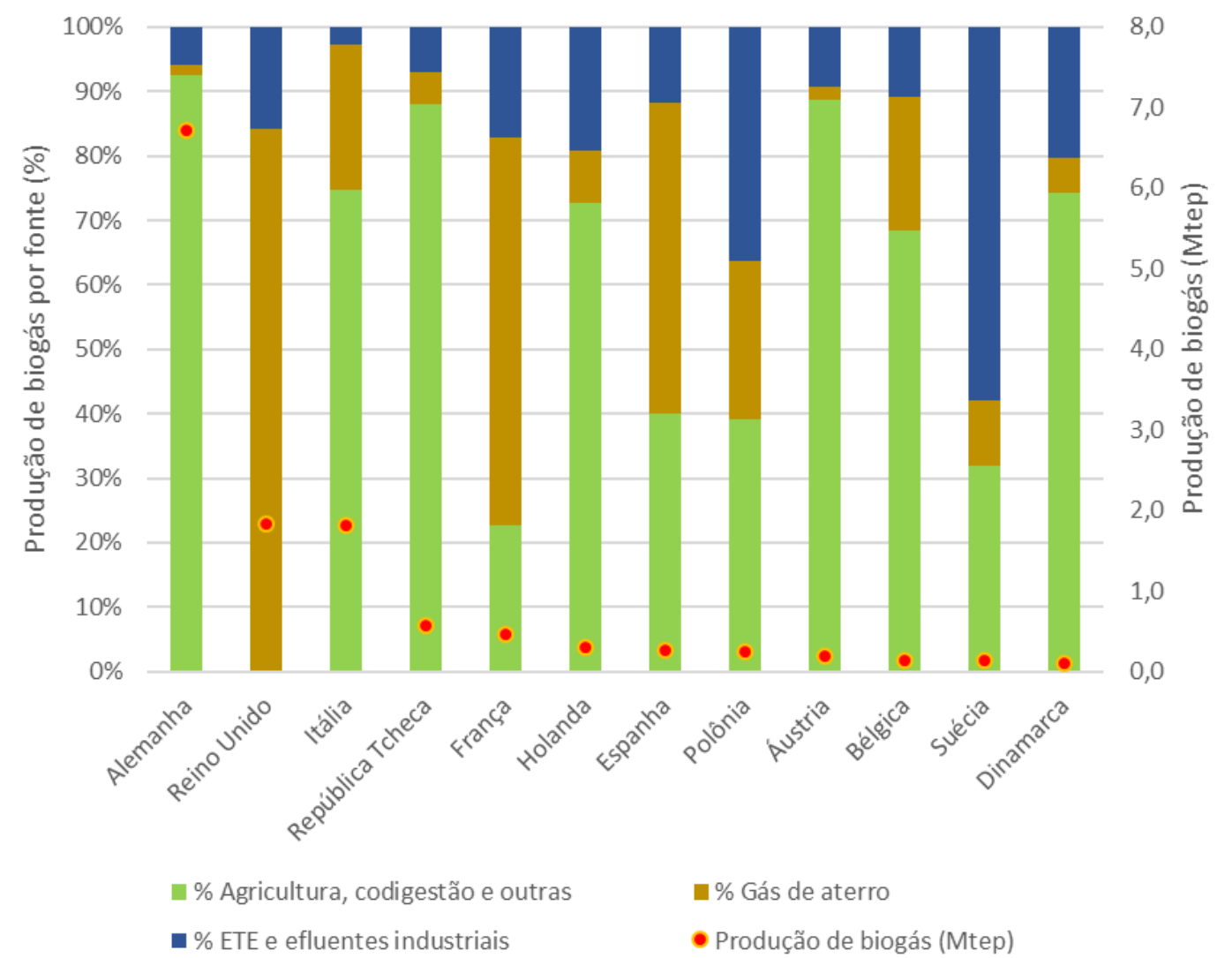

Fonte: elaborado a partir de EurObserv'ER (2014)

A utilização do biogás produzido também diferencia os sistemas dos países. O principal produtor europeu, a Alemanha, tem um sistema focado na geração de eletricidade. A Suécia, por outro lado, aproveita essa energia produzindo biometano para o uso em veículos. A Figura 16 mostra como alguns países europeus, membros da IEA Bioenergy Task 37, utilizam o biogás. 
Figura 16. Participação das formas de utilização do biogás em países selecionados da Europa

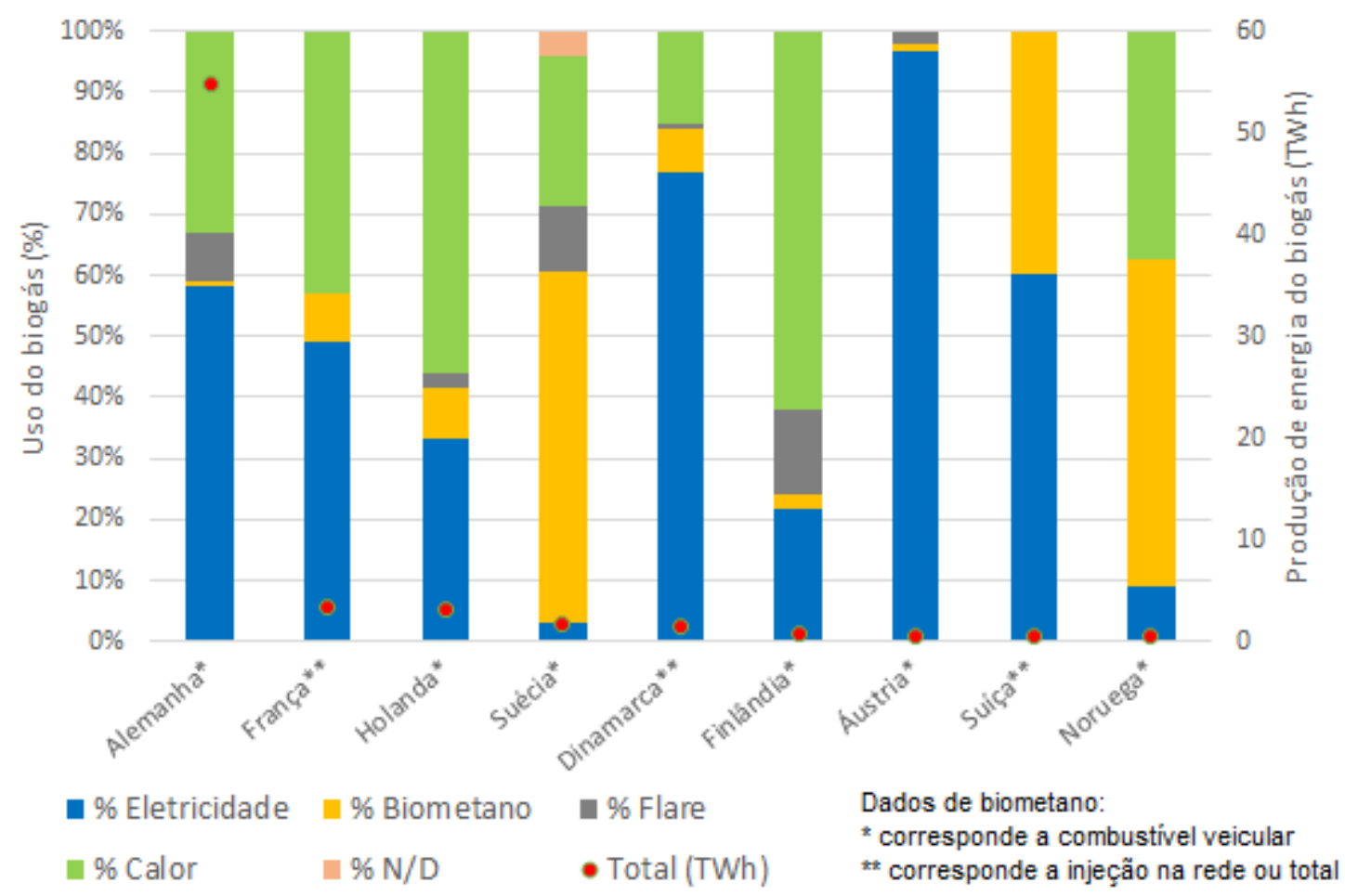

Fonte: elaborado a partir de IEA Bioenergy (2016).

Da Figura 16 pode-se notar que a geração de eletricidade é o uso predominante na maioria dos países europeus, entre eles a Alemanha. Segundo EBA (2014), tarifas feed-in de eletricidade para o biogás existem em diversos países na Europa, sendo a forma mais disseminada de incentivo ao uso dessa fonte.

Por outro lado, outros países se destacam na utilização de biometano como combustível veicular, ao menos na participação relativa. A Suécia e a Noruega, por exemplo, aproveitam mais da metade da energia do biogás produzida localmente para este fim; no entanto, são países cuja produção de biogás é pequena se comparada à da Alemanha.

Na Alemanha, mesmo que o uso como combustível veicular seja de apenas cerca de $1 \%$ da energia total, a produção de biometano também é destaque, sendo a maior do mundo. A Suécia é o terceiro principal produtor, como mostra a Figura 17. 
Figura 17. Produção de biometano e participação de seu uso como combustível veicular nos principais países produtores em 2013

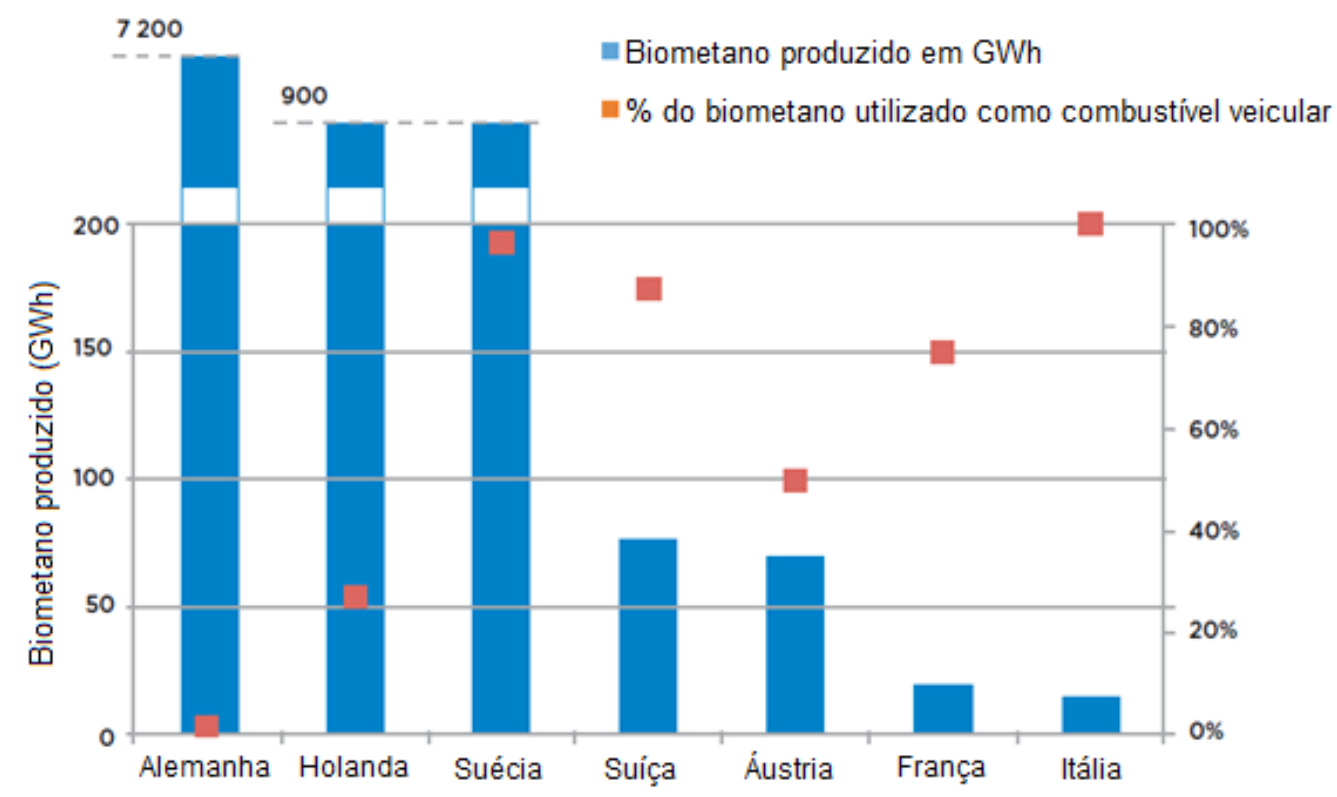

Fonte: adaptado de Stambaský et al. ${ }^{9}$ (2015) apud IRENA (2017)

Para a proposta deste trabalho, interessa a análise dos sistemas de utilização dos países, especialmente os que apresentam características claras em relação ao direcionamento do uso. Ou seja, são mais relevantes, nesse caso, países que tendem a um "uso prioritário" como, por exemplo, aproveitar o biogás majoritariamente para a produção de energia elétrica, ou majoritariamente para a produção de biometano.

Baseado nesse critério, e analisando os dados mundiais de produção e utilização apresentados, dois países foram escolhidos para a análise de seus setores de biogás, especialmente na utilização: a Alemanha e a Suécia. O primeiro, como representante da utilização de biogás para geração de energia elétrica; o segundo, para produção de biometano. A escolha desses países também é possível pela disponibilidade de dados e análises sobre seus sistemas de biogás, encontradas em artigos e teses.

\footnotetext{
9 Štambaský, J. Dr., Prządka, A., Kovács, E., Pflüger, S., de la Vega, N., Peón, B. (2015). Biomethane and Biogas Report 2015, European Biogas Association, Brussels.
} 


\subsubsection{Alemanha}

A Alemanha é um dos países líderes no setor de biogás, sendo o maior produtor mundial de eletricidade a partir dessa fonte. As características do setor e o rápido e grande desenvolvimento dessa indústria no país o torna peculiar em relação aos outros.

Projetos de produção de biogás associados à agricultura começaram no país na década de 1970 (SCOPE, 2015); no entanto, passaram a ser significativos a partir de 1990. Markard, Wirth e Truffer (2016) fizeram uma análise do biogás no setor agrícola na Alemanha - o maior setor em termos de número de plantas e produção de energia com biogás - dividindo o período de 1990 a 2012 em 3 fases, descritas a seguir.

Na primeira fase, de 1990 a 2001, o contexto era de grande atenção a efeitos ambientais negativos da agricultura e de adoção no país de tarifa feed-in para eletricidade renovável, ainda sem diferenciação entre tecnologias. A produção de biogás era vista como uma ferramenta para fazer a reciclagem dos resíduos orgânicos na agricultura e como um importante elemento da economia circular. As plantas eram instaladas com os objetivos de fertilização e enriquecimento do solo, de tratamento de dejetos animais e de proteção de lençóis freáticos, de forma integrada e adaptada à atividade principal. A produção de energia e a busca por receitas adicionais tiveram importância secundária (MARKARD; WIRTH; TRUFFER, 2016).

A segunda fase, de 2002 a 2006, é chamada pelos autores de "o primeiro boom". No contexto, a dificuldade econômica na agricultura pelos preços baixos dos alimentos - e, como consequência, fazendeiros abandonando os negócios, concentração e aumento do tamanho de fazendas e disponibilidade de terras para cultivo - e a decisão do governo alemão de eliminar gradativamente a energia nuclear, acompanhada do forte apoio para renováveis. O biogás era visto como alternativa para contribuir com a solução dos problemas da agricultura e como mais um elemento da transição energética (MARKARD; WIRTH; TRUFFER, 2016).

O instrumento de incentivo adotado foi a Lei das Fontes Renováveis de Energia (do alemão Erneuerbare-Energien-Gesetz - EEG), com a primeira versão em 2000 e atualização em 2004, esta caracterizando forte fomento ao biogás. Foram introduzidas tarifas feed-in, garantidas por um período de 20 anos, distintas para cada tecnologia de energia renovável e com diversas regras para estimular características específicas. Essas tarifas foram responsáveis por tornar a produção de biogás atrativa, inclusive no uso de culturas energéticas como substrato, levando a uma adoção em massa dessa opção. Mesmo com a redução da tarifa quanto 
maior o tamanho da planta, o novo perfil foi de unidades de maior porte, construídas por empresas especializadas (MARKARD; WIRTH; TRUFFER, 2016).

A terceira fase, de 2007 a 2012, consolidou a expansão - um segundo boom - e a transformação da tecnologia, que passou a ser apresentada como uma alternativa à agricultura e não mais um complemento, e como um dos pilares fundamentais da transição energética por suprir demanda de base, de pico e pelo papel de balancear o suprimento intermitente, típico de outras renováveis. No contexto, destacam-se o acidente de Fukushima e a decisão de manter o desligamento das usinas nucleares e maior atenção às mudanças climáticas. A oportunidade de negócio no setor de biogás foi mantida com a renovação da EEG de 2009, com bônus se o substrato fosse composto, no mínimo, por $30 \%$ de dejeto animal e se houvesse um uso mínimo do calor na cogeração (MARKARD; WIRTH; TRUFFER, 2016).

A profissionalização ainda maior da indústria fez com que fossem montados novos modelos comerciais de plantas, como as de propriedade de empresas de energia, que instalavam unidades de grande porte e tinham os fazendeiros apenas como fornecedores. No processo, as características da fazenda passaram a se subordinar à produção de biogás, e não o contrário, como era no início. $\mathrm{O}$ uso de culturas energéticas como substrato dominante marcou o período - especialmente o milho -, e foi um dos principais motivos das críticas que a produção de biogás passou a receber. Em um contexto de alta nos preços dos alimentos e no preço da terra cultivável, havia a percepção de que a geração de energia estava competindo com a produção de alimentos, e o biogás podia ser avaliado como ameaça à produção agrícola convencional (MARKARD; WIRTH; TRUFFER, 2016).

Somavam-se às críticas ao biogás efeitos negativos na biodiversidade, na comunidade e na paisagem. Na renovação da EEG de 2012, os bônus acima da tarifa base foram removidos e seus critérios passaram a ser obrigatórios. Segundo Markard, Wirth e Truffer (2016), a redução dos incentivos tinha o objetivo de frear o crescimento da indústria no modelo do período. Tabela 6 resume o período e as características das fases apresentadas.

Em nova atualização da EEG em 2014, foi limitado ainda mais o uso de culturas energéticas e restringiu-se os incentivos à produção a partir de resíduos (IEA BIOENERGY, 2016a; VEIGA, 2016). A recente mudança de 2017 determinou que a contratação de novos projetos será feita na forma de leilões, com a capacidade adicionada condicionada ao limite estabelecido pelo governo (DENA, 2016; FINDEISEN, 2016). 
Tabela 6 - Resumo das características dos períodos do biogás do setor agrícola na Alemanha

\begin{tabular}{|c|c|c|c|}
\hline & Fase 1 (1990-2001) & Fase $2(2002-2006)$ & Fase 3 (2007-2012) \\
\hline $\begin{array}{l}\text { Contexto do } \\
\text { período }\end{array}$ & $\begin{array}{l}\text { Problemas ambientais } \\
\text { na agricultura; início } \\
\text { das tarifas feed-in }\end{array}$ & $\begin{array}{l}\text { Preços baixos de } \\
\text { alimentos e terra } \\
\text { cultivável disponível; } \\
\text { fortes incentivos na } \\
\text { EEG } 2004\end{array}$ & $\begin{array}{l}\text { Aumento de preços de } \\
\text { alimentos e da terra; } \\
\text { Fukushima e mudanças } \\
\text { climáticas no foco; EEG } \\
2009 \text { mantém } \\
\text { incentivos, EEG } 2012 \\
\text { reduz }\end{array}$ \\
\hline $\begin{array}{l}\text { Perfil do setor de } \\
\text { biogás agrícola }\end{array}$ & $\begin{array}{l}\text { Foco na agricultura } \\
\text { sustentável, } \\
\text { reciclagem dos } \\
\text { resíduos e qualidade } \\
\text { do biofertilizante; } \\
\text { plantas adaptadas à } \\
\text { unidade agrícola }\end{array}$ & $\begin{array}{l}\text { Renda adicional aos } \\
\text { produtores agrícolas e } \\
\text { elemento na transição } \\
\text { energética; cultura } \\
\text { energética adicionada à } \\
\text { produção }\end{array}$ & $\begin{array}{l}\text { Pilar fundamental da } \\
\text { transição energética; } \\
\text { alternativa à agricultura } \\
\text { convencional; } \\
\text { investimento lucrativo; } \\
\text { expansão baseada em } \\
\text { culturas energéticas; } \\
\text { críticas ao modelo }\end{array}$ \\
\hline $\begin{array}{l}\text { Tamanho médio } \\
\text { das plantas }(k W)\end{array}$ & $70 \mathrm{~kW}$ & $420 \mathrm{~kW}$ & $520 \mathrm{~kW}$ \\
\hline $\begin{array}{l}\text { Número de } \\
\text { plantas (Início- } \\
\text { Fim da fase) }\end{array}$ & $50-1300$ & $1600-3500$ & $3800-7500$ \\
\hline
\end{tabular}

Fonte: adaptado de Markard, Wirth e Truffer (2016).

De fato, a tendência de redução da expansão do setor se confirmou desde 2012, com a redução do número de novos projetos. A Figura 18 mostra a evolução do número de plantas de biogás no setor agrícola alemão, enquanto os dados da Tabela 7 consideram todas as matériasprimas e apresentam o número de plantas e a geração de energia elétrica e de calor por tipo de substrato em 2014 e 2015. 
Figura 18. Evolução do número de plantas e da capacidade de geração elétrica usando biogás no setor agrícola da Alemanha, de 2003 a 2016

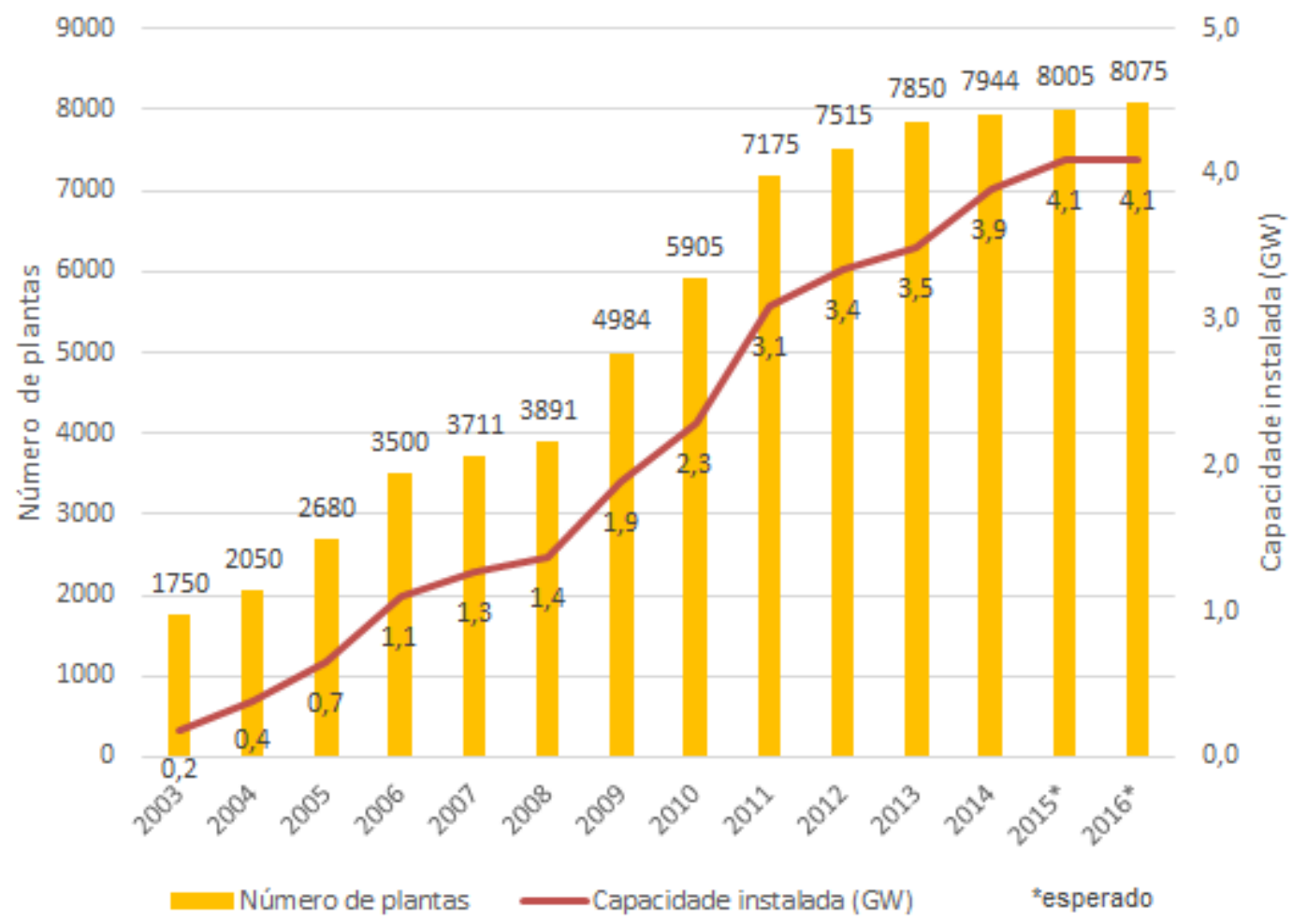

Fonte: elaborado a partir de FNR (2013) e FNR (2017).

Tabela 7 - Número de plantas, geração de eletricidade e de calor por tipo de substrato na produção de biogás na Alemanha, em 2014 e 2015.

\begin{tabular}{|l|l|l|l|l|l|l|}
\hline \multirow{2}{*}{$\begin{array}{l}\text { Tipo de } \\
\text { substrato }\end{array}$} & \multicolumn{2}{l|l}{$\begin{array}{l}\text { Número de } \\
\text { plantas }\end{array}$} & \multicolumn{2}{l|l}{$\begin{array}{l}\text { Geração de } \\
\text { eletricidade } \\
\text { (GWh/ano) }\end{array}$} & \multicolumn{2}{l|}{$\begin{array}{l}\text { Calor aproveitado } \\
\text { (GWh/ano) }\end{array}$} \\
\cline { 2 - 7 } & $\mathbf{2 0 1 4}$ & $\mathbf{2 0 1 5}$ & $\mathbf{2 0 1 4}$ & $\mathbf{2 0 1 5}$ & $\mathbf{2 0 1 4}$ & $\mathbf{2 0 1 5}$ \\
\hline ETEs & 1400 & 1400 & 1310 & 1390 & 1740 & 1979 \\
\hline $\begin{array}{l}\text { Resíduos } \\
\text { orgânicos }\end{array}$ & 180 & 180 & 850 & 903 & 360 & 480 \\
\hline Agricultura & 7960 & 8005 & 25120 & 28002 & 10550 & 14861 \\
\hline Industrial & 80 & 80 & 450 & 1204 & 190 & 639 \\
\hline Aterros & 400 & 400 & 540 & 390 & 90 & 110 \\
\hline Total & 10020 & 10065 & 28270 & 31890 & 12930 & 18069 \\
\hline
\end{tabular}

Fonte: adaptado de IEA Bioenergy (2015a) e IEA Bioenergy (2016a). 
As plantas de biogás na agricultura, segundo a Tabela 7, corresponderam a cerca de $89 \%$ e $88 \%$ da produção total de eletricidade total do biogás em 2014 e 2015, respectivamente. O crescimento do aproveitamento do calor sem aumento significativo do número de plantas indica maior eficiência no uso da energia em unidades já instaladas e/ou novas plantas de maior porte.

$\mathrm{Na}$ Alemanha, como efeito da EEG e das tarifas feed-in, o aproveitamento energético do biogás é majoritariamente voltado para a geração de eletricidade. Em 2015, 5\% do consumo de eletricidade alemão foi suprido pelo biogás, evidenciando o sucesso dessa indústria no país, sob os pontos de vista de potencial energético e capacidade de suprimento. A utilização do calor, seja na queima direta do biogás para este fim, seja resultado da cogeração, também é significativo. A Tabela 8 mostra os dados de utilização do biogás no país em 2015.

Tabela 8 - Aproveitamento energético do biogás por uso final, na Alemanha, em 2015

\begin{tabular}{|l|l|l|l|}
\hline Tipo de utilização & Energia (GWh/ano) & $\begin{array}{l}\text { Participação no } \\
\text { destino da energia } \\
\text { do biogás (\%) }\end{array}$ & $\begin{array}{l}\text { Participação no } \\
\text { consumo alemão } \\
(\%)\end{array}$ \\
\hline Eletricidade* & 31.890 & 58,1 & 5,0 \\
\hline Calor & 18.069 & 32,9 & 1,4 \\
\hline Combustível veicular & 580 & 1,1 & 0,1 \\
\hline Flaring & 4.379 & 8,0 & - \\
\hline
\end{tabular}

Fonte: elaborado a partir de IEA Bioenergy (2016).

Destaca-se, por outro lado, que o desenvolvimento da cogeração não foi acompanhado pelo uso de biometano como combustível em veículos, ainda que tenha evoluído nos últimos anos. Em 2010, foram comercializados 162 GWh de biometano veicular, enquanto em 2014 foram $580 \mathrm{GWh}$. Portanto, somente $1,1 \%$ da energia aproveitada do biogás teve este fim, mesmo com os mais de 98 mil veículos movidos a gás podendo ser abastecidos com $100 \%$ de biometano em até 150 postos de abastecimento, e com misturas contendo biometano e gás natural em mais de 300 (FNR, 2017). É considerado que o mercado de veículos a gás fícou abaixo das expectativas na Alemanha e se desenvolveu menos que em outros países (ROSENTIEL; HEUERMANN; HUSIG, 2015).

A produção de biometano na Alemanha se iniciou em 2006 com a instalação das duas primeiras plantas de purificação de biogás (DENA, 2016). Em 2015, 188 plantas de produção 
de biometano estavam em operação na Alemanha, correspondendo a 1,9\% do total. A capacidade de injeção de biometano na rede de gás natural era de $110.310 \mathrm{Nm}^{3} / \mathrm{h}$ (IEA BIOENERGY, 2016).

Considerando que toda essa capacidade fosse utilizada sem interrupções, e adotando uma concentração de biometano de 96,5\% em metano, a capacidade de injeção na rede seria de aproximadamente 9.297 GWh/ano. Considerando, ainda, uma eficiência na transformação elétrica de $35 \%$, seria possível produzir cerca de $3.254 \mathrm{GWh} /$ ano de eletricidade com essa capacidade, ou seja, 10,2\% da produção de eletricidade com biogás na Alemanha em 2015.

Segundo DENA (2016), enquanto, no geral, a produção europeia de biometano é aplicada como biocombustível em veículos a gás - com Suécia e Suíça como exemplos -, o mercado alemão de biometano é focado no uso em unidades de cogeração de eletricidade e calor.

Este modelo alemão também se baseia na EEG e suas tarifas para remuneração fixa de geração de eletricidade. A injeção de biometano na rede de gás natural não é remunerada diretamente; no entanto, o operador de uma planta de cogeração que usa gás da rede recebe subsídio equivalente ao do biogás pela eletricidade gerada, caso comprove a injeção de biometano na rede na mesma quantidade de gás utilizada na cogeração, ao final do período de um ano. Essa é uma das maneiras de estimular demanda ao biometano, que é negociado no mercado (DENA, 2016).

O objetivo é que ocorra a injeção de biometano na rede para que seja utilizado em locais em que a cogeração possa ser mais eficiente; por exemplo, onde há uma demanda significativa para o aproveitamento do calor gerado (DENA, 2016). Essa opção é facilitada pela vasta rede de gás natural existente na Alemanha, uma das mais extensas da Europa (VEIGA, 2016).

As leis EEG 2009 e 2012 incluíam ainda "bônus tecnológico" para o "processamento do gás", ou seja, a produção de biometano, caso cumpridos certos requisitos, alguns deles apresentados na Tabela 9. Os critérios para obtenção do bônus expressam a busca pela eficiência energética do sistema e o incentivo a plantas de menor porte, além do apoio a novas tecnologias. 
Tabela 9 - Restrições para obtenção de bônus tecnológico para plantas de produção de biometano nas leis alemãs EEG 2009 e 2012.

\begin{tabular}{|l|l|}
\hline Objeto da restrição & Restrição \\
\hline $\begin{array}{l}\text { Emissões máximas de metano para a } \\
\text { atmosfera durante o processamento }\end{array}$ & $\begin{array}{l}\text { EEG 2009: }<0,5 \% \\
\text { EEG 2012: }<0,2 \%\end{array}$ \\
\hline $\begin{array}{l}\text { Consumo de eletricidade durante o } \\
\text { processamento }\end{array}$ & $0,5 \mathrm{kWh} / \mathrm{Nm}^{3}$ de biogás bruto \\
\hline $\begin{array}{l}\text { Suprimento do calor de processo para } \\
\text { produção/processamento do gás }\end{array}$ & $\begin{array}{l}\text { Proveniente de fontes renováveis ou calor } \\
\text { residual do processo }\end{array}$ \\
\hline $\begin{array}{l}\text { Tamanho máximo da planta (o bônus } \\
\text { diminui, em categorias, quanto maior a } \\
\text { capacidade da planta) }\end{array}$ & EEG 2009: $700 \mathrm{Nm}^{3} / \mathrm{h}$ de biometano \\
\hline
\end{tabular}

Fonte: o autor a partir de Clearingstelle EEG (2009) e Clearingstelle EEG (2012).

O bônus tecnológico também se aplicava para, por exemplo, o uso de células a combustível, turbinas a gás, motores Stirling e a conversão de biomassa por gaseificação termoquímica. A busca por inovação em energias renováveis fez parte da estratégia alemã de desenvolvê-las, sendo instrumentalizada desde o investimento em pesquisa básica, mas principalmente pela EEG e as tarifas feed-in. Além do biogás, as fontes eólica e solar também receberam incentivos e tiveram rápido desenvolvimento no país.

A política industrial relacionada à Energiewende (termo que descreve a "transição energética", em alemão) pode ser considerado o mais importante projeto nacional (PEGELS; LUTKENHORST, 2014). O sucesso em construir tecnologias de ponta e a posição de liderança em diversos segmentos de energia renovável no mundo pode garantir competitividade, empregos e uma dinâmica de inovação por muitos anos. A política já deu resultados positivos: criou sistemas energéticos descentralizados e fortaleceu economias locais e regionais, incluindo as mais fragilizadas; o setor de energias renováveis empregava quase 380 mil pessoas na Alemanha em 2012 (PEGELS; LUTKENHORST, 2014); a economia em importação de combustíveis fósseis em 2012 foi estimada em 10 bilhões de euros; e a construção de plantas de energia elétrica e componentes gerou uma receita de exportação de cerca de 10 bilhões de euros em 2013 (RENEWABLE ENERGIES AGENCY, 2015).

Por outro lado, há diversas críticas a essa política alemã, em uma discussão altamente politizada. Entre elas, que os subsídios pagos pelo consumidor alemão teriam ajudado o desenvolvimento e o amadurecimento de tecnologias renováveis no mundo inteiro, que outros 
países, como a China, podem explorar, competindo com a Alemanha pelos mercados; também há posições contrárias, por exemplo, à especificidade tecnológica das tarifas feed-in, que não teriam permitido que o mercado escolhesse a solução mais eficiente (PEGELS; LUTKENHORST, 2014).

De acordo com a análise dos dados e das estratégias instrumentalizadas nos incentivos concedidos pelo governo alemão, nota-se que há direcionamento da utilização do biogás para a geração de energia elétrica. A expansão do biogás como alternativa de geração de eletricidade foi baseada nas tarifas feed-in estabelecidas na EEG. Outras regras e estímulos implementados, como para o desenvolvimento da produção de biometano - do qual a Alemanha é a maior produtora mundial - e para o aproveitamento do calor, se justificam pela inovação tecnológica e melhor aproveitamento do recurso energético; as formas de incentivo, os dados, e os relatos indicam que o objetivo final era a produção de eletricidade.

Essa conclusão sobre o sistema alemão de biogás permite a análise das condições que possam ter norteado a decisão. A EEG, que estimulou o desenvolvimento do biogás para energia elétrica, incentivou também o de outras fontes renováveis, como a energia solar fotovoltaica e energia eólica. A estratégia buscava aumentar a participação de fontes renováveis em um setor elétrico dominado pela geração por energias fósseis, especialmente o carvão, e energia nuclear (FRONDEL et al., 2010). A Figura 19 apresenta a evolução da geração de energia elétrica na Alemanha, a partir de 1998, dois anos antes da publicação da primeira EEG. 
Figura 19. Geração anual de eletricidade por tipo de fonte na Alemanha, de 1998 a 2014 700

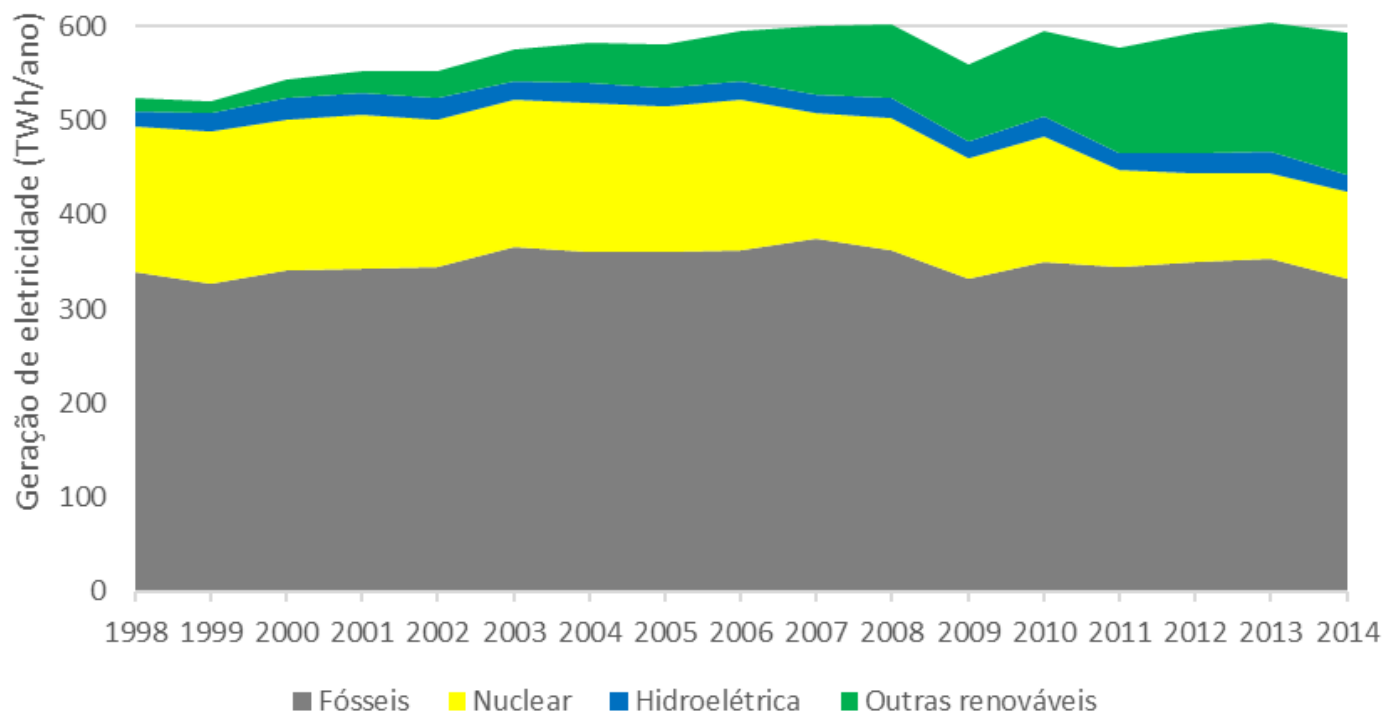

Fonte: elaborado a partir de EIA (2017).

Segundo a Figura 19, a geração de eletricidade da Alemanha na época da publicação da EEG 2000 era dominada por fontes fósseis. Apesar da inserção das fontes renováveis, esse cenário se manteve. Entre as fósseis, o cenário também é similar ao do final da década de 1990. O carvão se mantém como a principal fonte de geração de energia elétrica entre as fósseis, representando mais de $70 \%$ delas ao longo de todo o período analisado, como mostra a Figura 20. 
Figura 20. Participação do carvão, petróleo, e gás natural na geração de energia elétrica por fontes fósseis na Alemanha, de 1998 a 2014

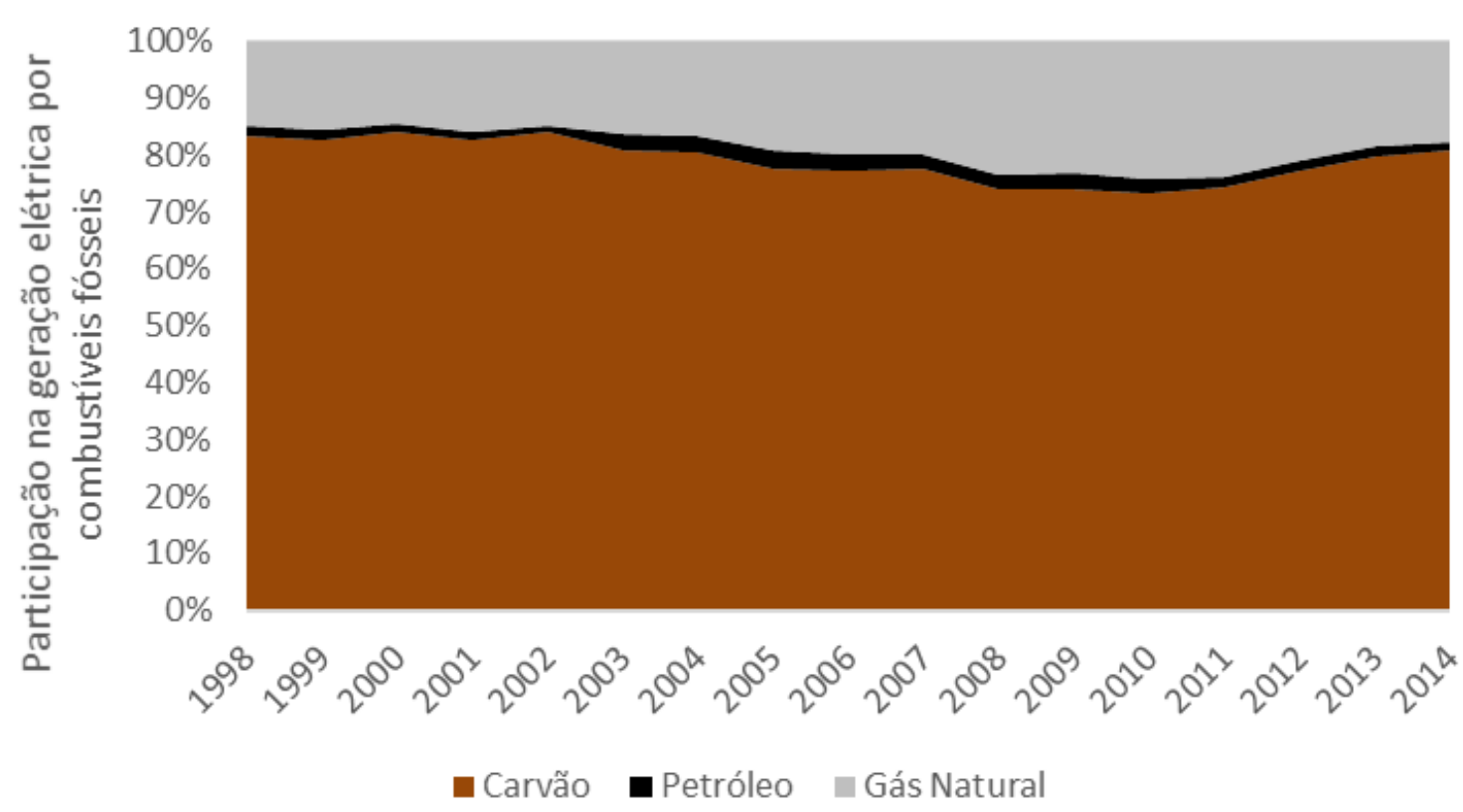

Fonte: elaborado a partir de World Bank (2017).

Portanto, o uso de fontes fósseis para geração de energia elétrica na Alemanha se manteve relativamente estável. Segundo Morey e Kirsch (2014), o carvão continua importante no setor devido a confluência de três fatores: o efeito que energias renováveis têm de diminuir os preços spot de venda de energia no mercado atacadista ${ }^{10}$, os altos preços do gás natural que inviabilizam a geração por essa fonte, e os preços baixos do carvão no mercado internacional.

Apesar de a introdução de fontes renováveis, mesmo na Alemanha, estar muito associada à substituição de fontes fósseis e à redução nas emissões de GEE (MORRIS; PEHNT, 2016), nota-se da Figura 19 que a mudança mais significativa se deu na geração de energia nuclear do país. A produção por essa fonte diminuiu de 154 TWh em 1998 para 92 TWh em 2014, uma redução de mais de 40\% (EIA, 2017).

De fato, o fim da energia nuclear na Alemanha é um dos principais objetivos da Energiewende. O termo surgiu nos movimentos contra essa fonte na década de 1970, que ganhou força e resultou no acordo de 2000, que previa o fechamento programado de todas as plantas. O acidente de Fukushima, no Japão, em 2011, e os protestos que ocorreram em seguida, fizeram o governo alemão adiantar a previsão de fechamento das plantas para 2022. A

\footnotetext{
${ }^{10}$ Ao se inserir fontes renováveis com remuneração garantida por meio de tarifas feed-in, como na Alemanha, a demanda restante a ser atendida no mercado atacadista de eletricidade diminui, reduzindo os preços (SENSFU $\beta$; RAGWITZ; GENOESE, 2008).
} 
Alemanha rejeita a energia nuclear pelos riscos, os custos e a questão não-resolvida dos resíduos nucleares (MORRIS; PEHNT, 2016).

Segundo Hake et al. (2015), o processo de transição energética na Alemanha, proveniente de um consenso político com muitas tensões e conflitos, é caracterizado pela desativação da energia nuclear no curto prazo e pela eliminação do carvão no médio prazo. Portanto, a relação do país com a energia nuclear é importante para que estratégias de inserção de fontes renováveis sejam direcionadas ao setor elétrico.

Portanto, a atual dependência de combustíveis fósseis e da energia nuclear, fontes que são, por diferentes razões, consideradas indesejáveis pelo país, foram e se mantém sendo motivos para os incentivos para fontes de energia elétrica renováveis, além de objetivos como segurança energética e estímulo à inovação (MORRIS; PEHNT, 2016). De fato, a geração por fontes renováveis, como eólica, solar e biomassa, tem aumentado ano a ano na Alemanha, como mostrou a Figura 19, e a Figura 21 detalha.

Figura 21. Geração anual de eletricidade por fontes renováveis na Alemanha, de 1998 a 2014

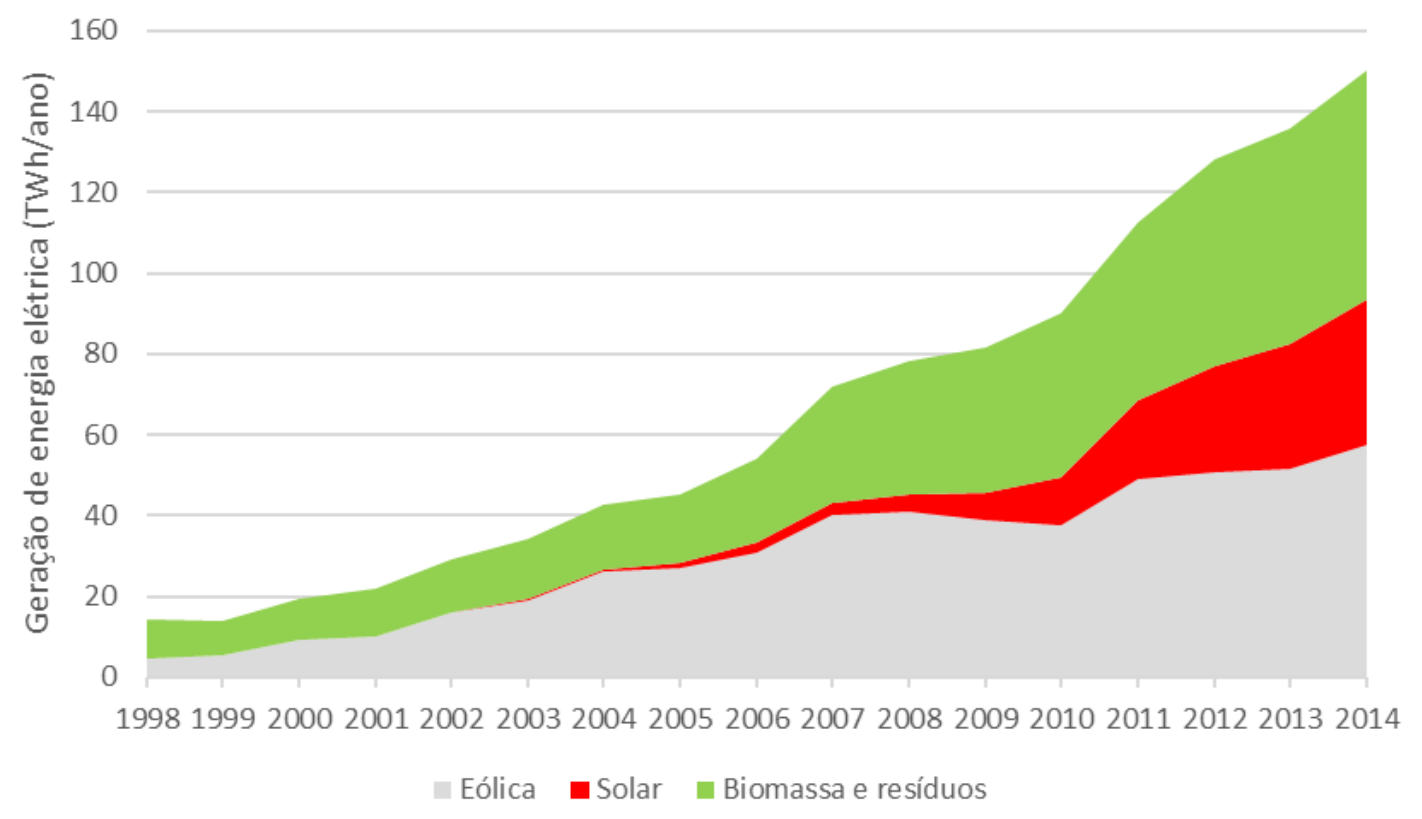

Fonte: elaborado a partir de EIA (2017).

$\mathrm{Na}$ Alemanha, a entrada de novas renováveis, com a característica da variabilidade de produção, coloca expectativas no biogás de que sua capacidade de armazenamento e produção flexível podem ser trunfos para seu desenvolvimento. O suprimento regular, ao longo do dia e do ano, e despachável fornecido pelo biogás e biometano, segundo DENA (2016), tem a capacidade de balancear a produção flutuante de outras renováveis, como eólica e fotovoltaica. 
Diversos atores do setor de biogás alemão apontam para esse como o novo papel prioritário do biogás na produção de eletricidade: a flexibilidade, em vez de atender a demanda de base (URBAN, 2013; FINDEISEN, 2016). Segundo FNR (2013), há esforços em curso para expandir a produção de biogás flexível e orientada pela demanda. Hahn et al. (2014), analisando o caso alemão, afirmam que a eletricidade do biogás não foi usada dessa maneira no passado e, por isso, alguns conceitos estão em estágio inicial de implementação técnica, mas avaliam essa estratégia como "vital” para balancear a geração de energia elétrica.

Portanto, todas as renováveis, a biomassa e o biogás incluídos, prosperam com a oportunidade de diminuição da dependência das fontes fósseis e nuclear na Alemanha; a biomassa, e o biogás incluído, pode prosperar com a oportunidade do aumento das renováveis no setor elétrico alemão. Em todo caso, a indicação é de que, na Alemanha, o biogás permanecerá sendo utilizado para geração de eletricidade em plantas de cogeração, e a produção de biometano tende a ser uma estratégia para aumentar a eficiência do sistema.

\subsubsection{Suécia}

O começo da produção de biogás na Suécia data de meados do século XX, inicialmente como processo em estações de tratamento de esgoto (ETE). Desde então, foram várias etapas até chegar na solução atual, um sistema que, no seu estado-da-arte, combina tratamento de resíduos em plantas de codigestão com os benefícios ambientais da produção de biometano destinado ao setor de transportes.

Olsson e Fallde (2015) relatam que, inicialmente, a digestão anaeróbia em ETEs foi uma ferramenta empregada para reduzir o volume de lodo, os odores e eliminar matéria infecciosa. Ao longo do tempo, como resposta à legislação ambiental, indústrias do setor de alimentos e celulose também adotaram a tecnologia para tratamento de água residual, e o uso do biogás para produção de calor e eletricidade também surgiu no país. Na década de 1980 apareceram os primeiros projetos de coleta de biogás de aterros sanitários, visando diminuir a liberação de metano para a atmosfera. Em todos estes casos, o principal fator de desenvolvimento foi o gerenciamento dos resíduos e a melhoria do desempenho ambiental. No entanto, nesse período, no contexto da crise do petróleo de 1973-74, também houve a promoção de incentivos ao biogás de resíduos agropecuários com o uso foi direcionado para energia térmica.

A partir da década de 1990, o biogás, e sua sinergia com o gás natural, passou a ser visto como alternativa para contribuir com a solução de problemas de poluição local associada ao 
transporte, como material particulado. Assim, houve um processo de mudança de status do biogás. Antes considerado basicamente um subproduto, foi se transformando em uma solução de maior complexidade tecnológica, que exige tratamento adequado para assumir a nova condição de energético substituto, por exemplo, do diesel. Nesse processo, a produção de biogás também foi sendo sofisticada com a adoção de plantas de codigestão e a diversificação de substratos (OLSSON; FALLDE, 2015).

$\mathrm{Na}$ prática, iniciativas municipais e regionais para desenvolver o biometano como combustível veicular avançaram na década de 2000. O convencimento dos formuladores de políticas para que, nessas esferas, houvesse incentivo para a utilização do biogás foram importantes, combinado com a influência das empresas de tratamento de água e de ETEs, que viam novas oportunidades de negócios. Nesse ponto, fica claro que os interesses econômicos também passaram a motivar essa alternativa (OLSSON; FALLDE, 2015).

Os dados da evolução dos substratos utilizados para produção e das características do uso do biogás na Suécia mostram as alterações do sistema. A análise dos tipos de substrato mostra que as plantas de codigestão de fato corresponderam ao aumento na produção nos últimos anos, tendo em 2015 participação maior que o biogás de ETEs, como mostra a Figura 22.

Figura 22. Evolução da produção de biogás por substrato na Suécia, de 2005 a 2015

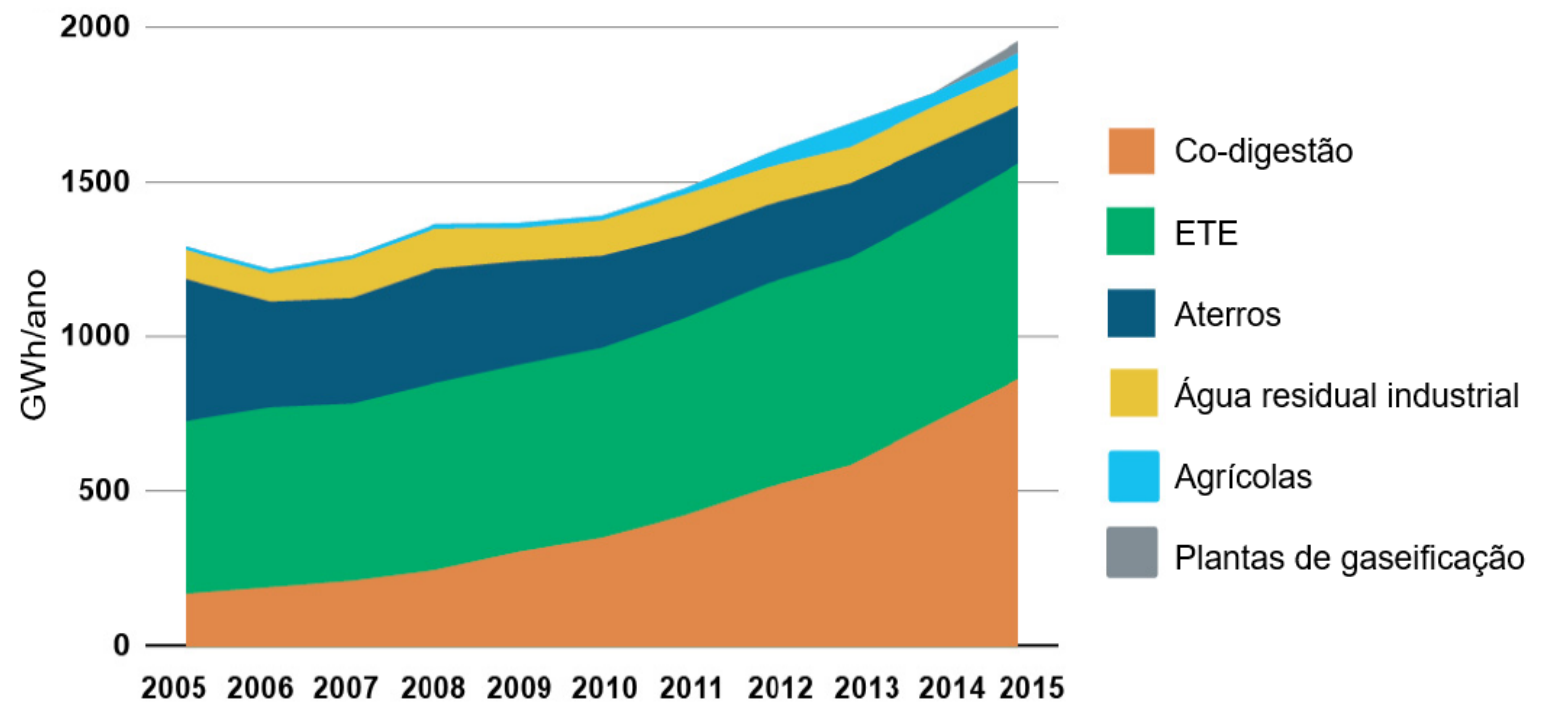

Fonte: adaptado de ENERGIGAS SVERIGE (2016) e SVENSSON (2016).

Por sua vez, os dados de utilização do biogás na Suécia revelam a tendência de produção de biometano para uso no setor de transportes. A Figura 23 mostra a transformação do sistema 
desde 2005 e a quantidade de energia de forma absoluta, enquanto a Figura 24 apresenta dados de participação relativa dos usos no ano de 2015.

Figura 23. Evolução dos usos de biogás na Suécia, de 2005 a 2015

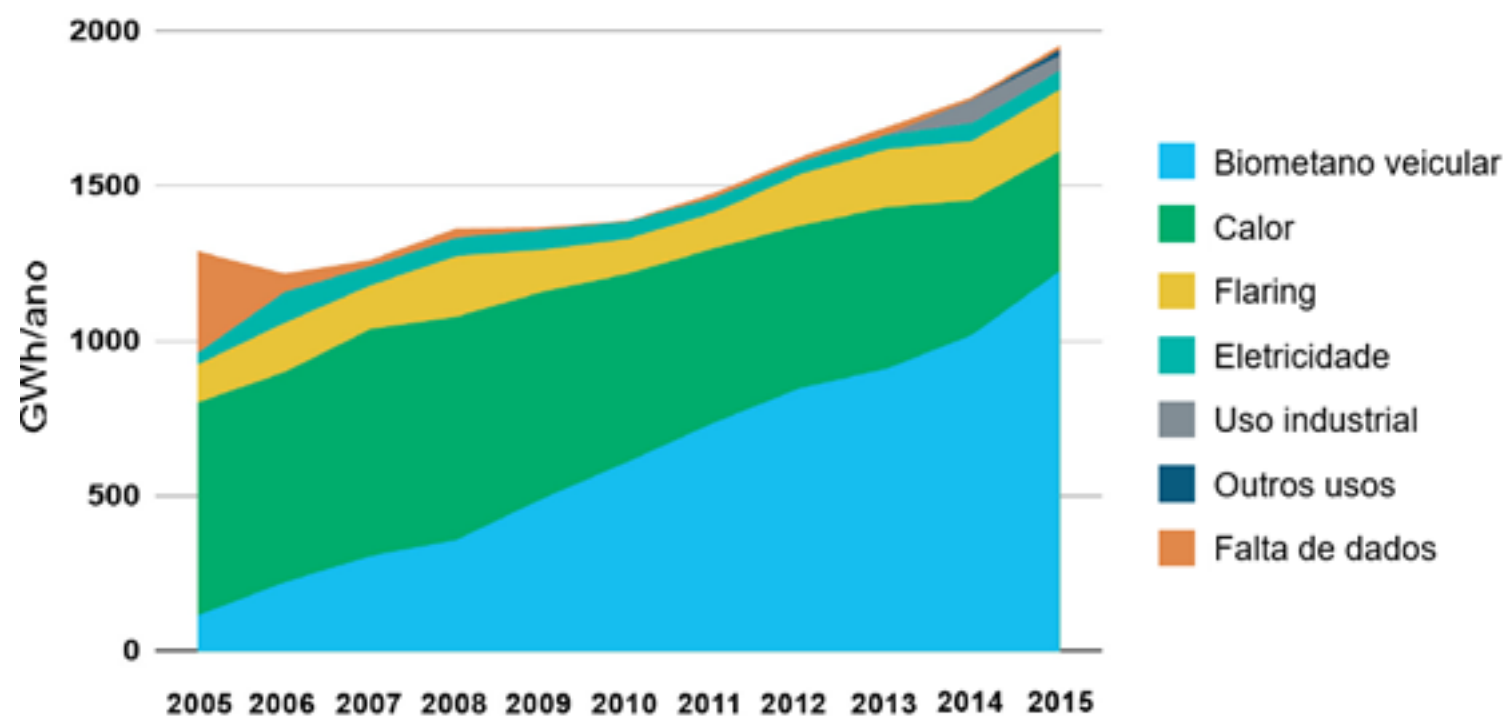

Fonte: adaptado de ENERGIGAS SVERIGE (2016) e SVENSSON (2016).

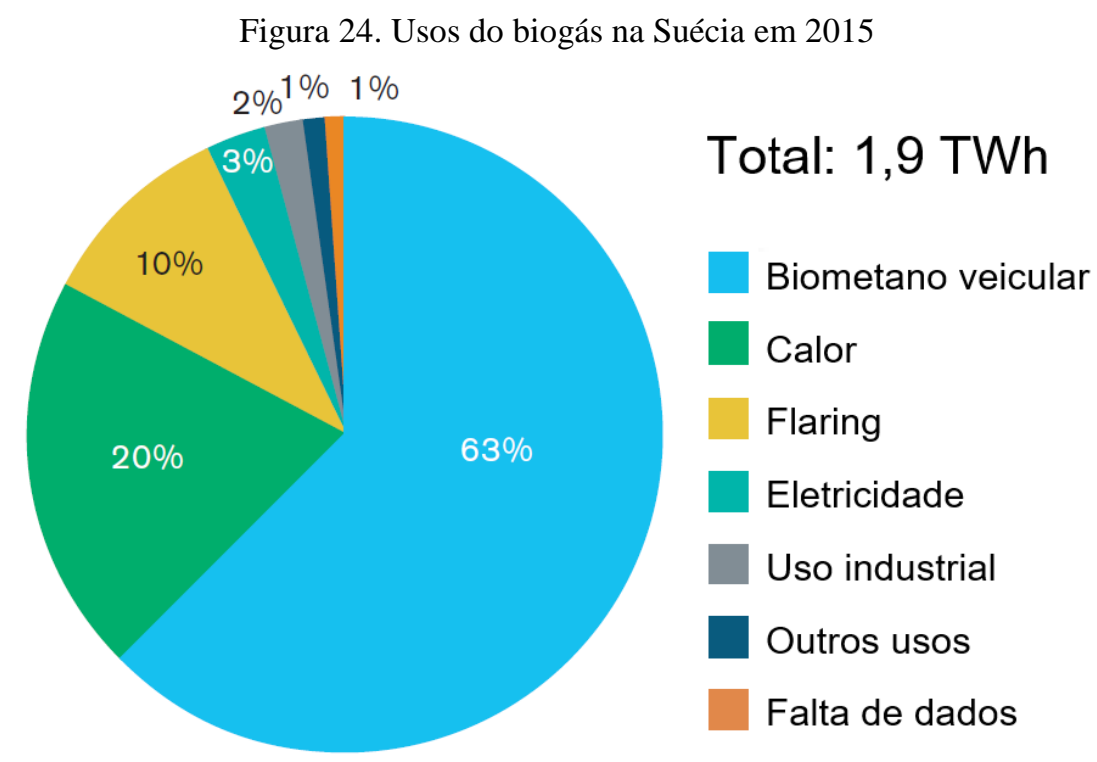

Fonte: adaptado de ENERGIGAS SVERIGE (2016) e SVENSSON (2016).

Segundo a Figura 24, na Suécia, 63\% da energia do biogás é utilizada como combustível veicular. O biometano com esse destino é comercializado como "gás veicular", que consiste basicamente de metano, e pode ser uma mistura com o gás natural fóssil. O consumo de gás 
veicular no país mais que triplicou no país desde 2005, sendo que o biometano passou a compor a maior parte desse combustível a partir de 2007. A Figura 25 mostra essa tendência.

Figura 25. Participação do biometano e do gás natural no gás veicular da Suécia, de 2000 a 2014

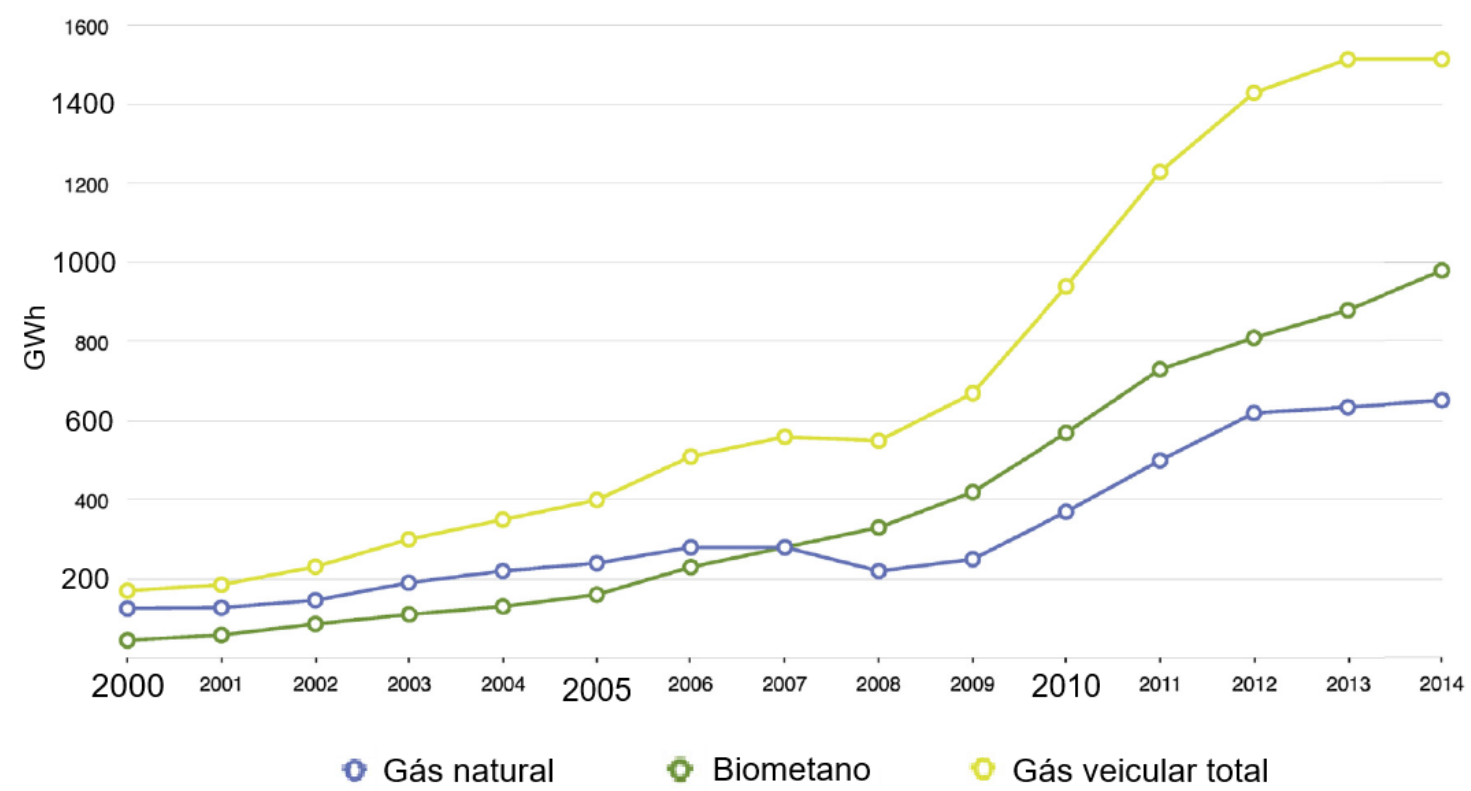

Fonte: adaptado de SANCHES-PEREIRA et al. (2015).

Nota-se, portanto, que o setor de biogás na Suécia está direcionado para a produção de biometano como combustível veicular. É de interesse para esta análise compreender os fatores que levaram a essa característica; ou seja, se foi baseada no mercado - nos custos de produção e preços das alternativas - ou em políticas orientadas para gerar esse resultado, instrumentalizadas por incentivos.

Segundo Svensson (2015, p. 9, tradução nossa), "o sistema de incentivos na Suécia é focado principalmente em aumentar o uso de biometano como combustível veicular".

Para Larsson et al. (2016), a Suécia é um país líder no desenvolvimento do biometano no setor de transportes devido a uma composição de políticas e instrumentos de incentivo direcionados a toda a cadeia de biogás, desde a produção ao uso.

Entre os instrumentos de estímulo ao uso de biogás no setor de transporte implementados na Suécia podem ser citados (SANCHES-PEREIRA et al., 2015; LARSSON; GRONKVIST; ALVFORS, 2016):

- Isenção de impostos para o biogás utilizado como combustível veicular e para geração de calor; 
- Apoio para investimentos em toda a cadeia do biogás - programas Local Investment Program (LIP) e Climate Investment Program (KLIMP) - e para projetos com novas tecnologias;

- Obrigação de postos de combustíveis a partir de certo tamanho de comercializarem um combustível renovável;

- Bônus na compra e diferenciação de imposto para veículos "limpos", dependendo das emissões de $\mathrm{CO}_{2}$ por quilômetro;

- Incentivos locais como estacionamento gratuito e isenção de pedágio urbano em Estocolmo.

Além do apoio com redução de impostos e do estímulo financeiro a investimentos privados na produção, infraestrutura, e demanda, esquemas de compras públicas (public procurement, em inglês) de veículos a gás também foram importantes para o sucesso da política (LARSSON; GRONKVIST; ALVFORS, 2016).

Sanches-Pereira et al. (2015) citam que um importante fator para o crescimento de uso de gás como combustível de transporte em Estocolmo - de 62 para 407 GWh no período de 2007 a 2014 - foi a visão de longo prazo da empresa responsável pelo transporte público de desenvolver uma frota de ônibus independente de combustíveis fósseis, e os investimentos realizados nesse sentido.

No entanto, mesmo com todos os incentivos, parte da competitividade do gás veicular é avaliada no mercado, na comparação entre seu preço e o de outros combustíveis, como a gasolina. Sanches-Pereira et al. (2015) mostram que a trajetória dos preços do gás veicular é semelhante à dos preços da gasolina, sempre mantendo próximos os custos com combustível por distância percorrida. Assim, compreende-se que a viabilidade de projetos de produção de biometano e a atratividade do veículo a gás para o consumidor depende dos preços da gasolina, que, por sua vez, dependem dos preços do petróleo. Também é reconhecido que a participação do gás natural misturado ao biometano contribui com a competitividade dos preços do gás veicular no mercado (SANCHES-PEREIRA et al., 2015; LARSSON; GRONKVIST; ALVFORS, 2016).

Portanto, é claro que o sistema de biogás sueco determinou o direcionamento da utilização dessa energia como biometano veicular. Segundo Larsson (2016, p. 3778, tradução nossa),

O biogás esteve disponível por várias décadas nas plantas de tratamento de esgoto, mas apenas recentemente a fração de biometano passou a aumentar. A 
razão para isso é o interesse político local e nacional de usar o biogás como um combustível renovável para o setor de transportes e os instrumentos de política que resultaram desse interesse.

Nota-se que a Suécia buscou uma estratégia pouco comum entre outros países, mais complexa em termos tecnológicos, e que necessita de um sistema de infraestrutura desenvolvido para sua implementação. Pode-se afirmar, portanto, que a opção de o biogás competir no setor elétrico do país foi preterida. As características da geração de eletricidade na Suécia são apresentadas na Figura 26.

Figura 26. Geração anual de eletricidade por tipo de fonte na Suécia, de 1998 a 2014

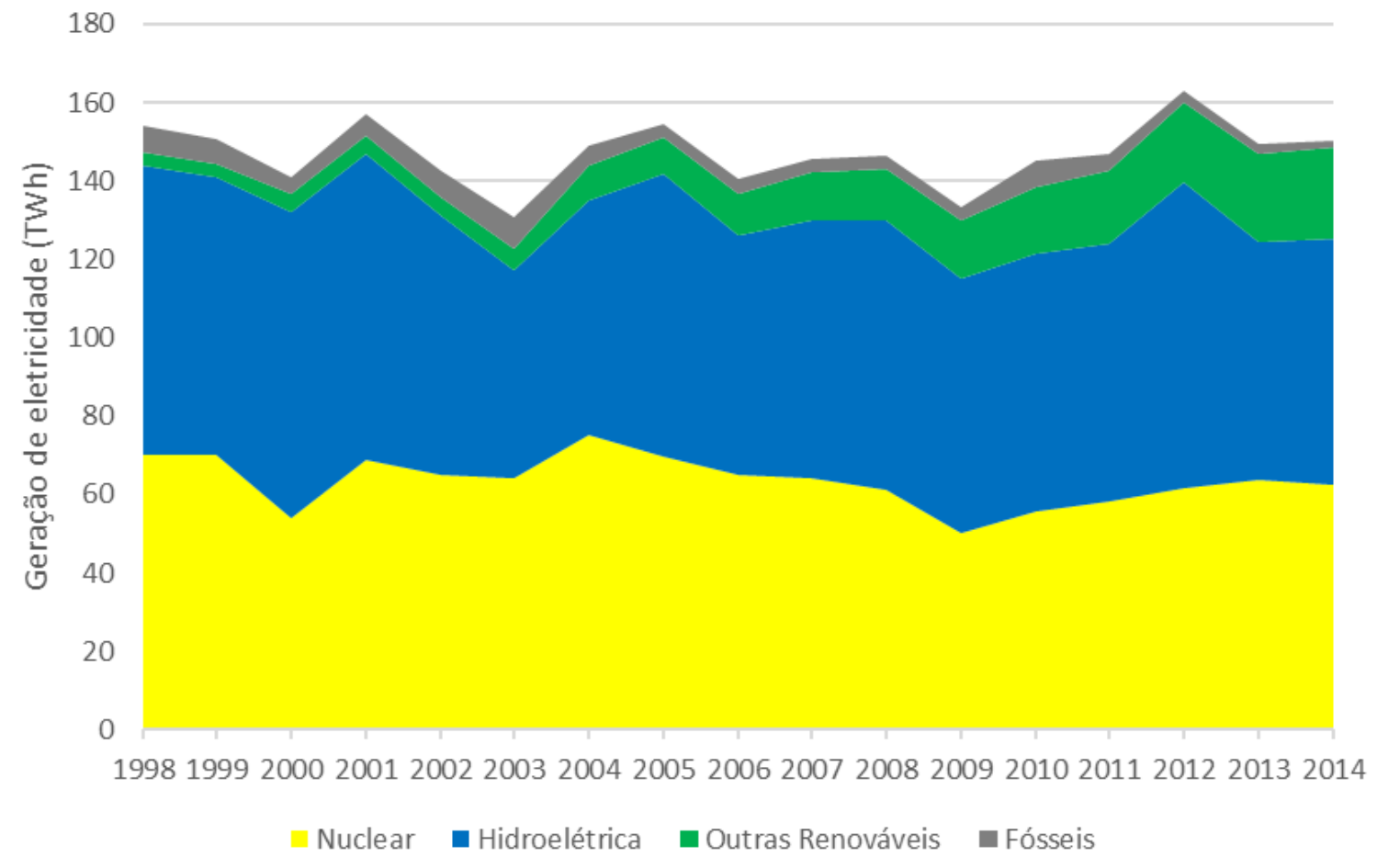

Fonte: elaborado a partir de EIA (2017).

Segundo a Figura 26, a geração de eletricidade na Suécia é dominada pelas fontes hidráulica e nuclear, enquanto os combustíveis fósseis têm participação relativamente pequena. O crescimento da participação de outras fontes renováveis no período apresentado é notável, e é detalhado pela Figura 27. 
Figura 27. Geração anual de eletricidade por fontes renováveis na Suécia, de 1998 a 2014

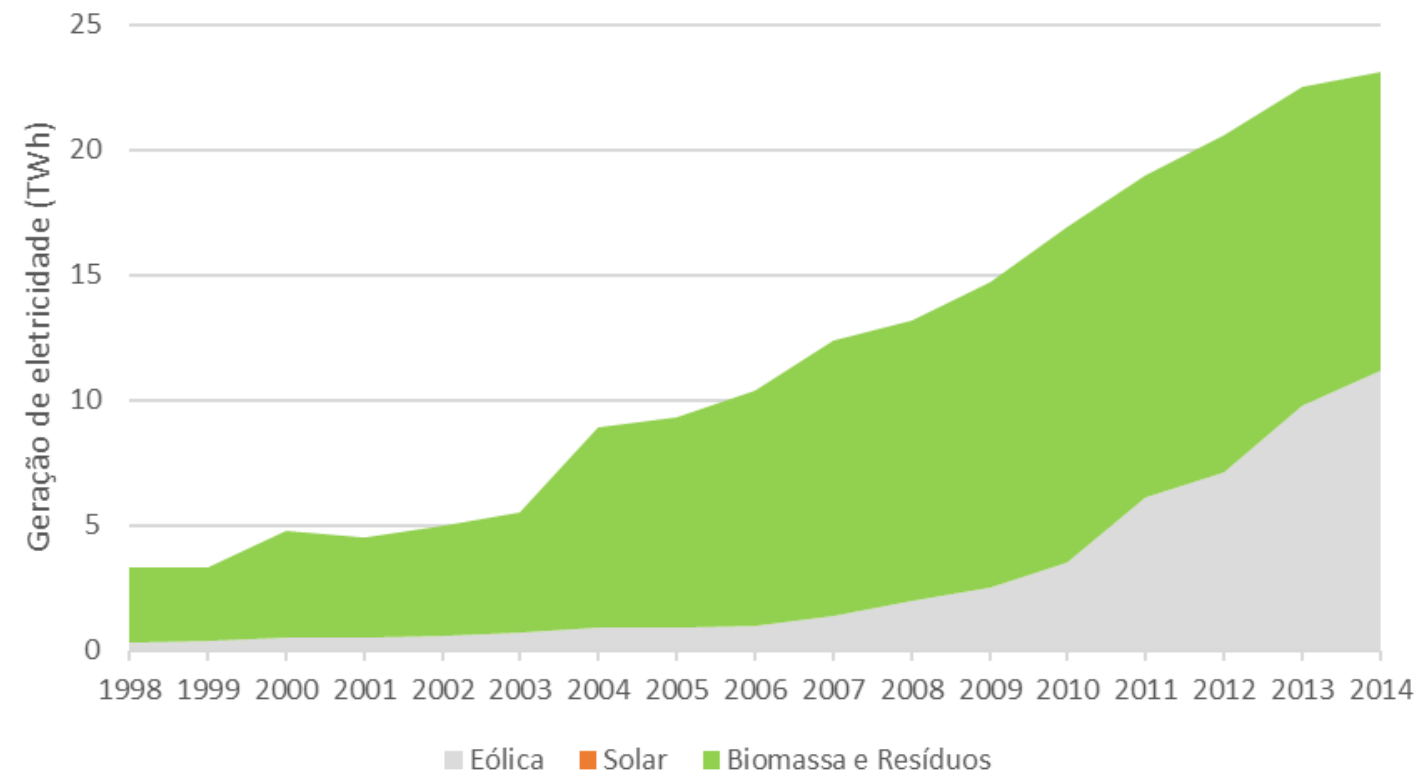

Fonte: elaborado a partir de EIA (2017).

A Figura 27 mostra que o crescimento das renováveis na geração de eletricidade sueca foi impulsionado por biomassa e resíduos, em um primeiro momento, e pela energia eólica, em seguida. Em 2014, as duas fontes praticamente dividiram a geração por fontes renováveis nãohídricas no país.

De forma geral, nota-se que não há espaço, na matriz elétrica sueca, para a redução do uso de combustíveis fósseis e, consequentemente, de emissões de GEE. No caso da Alemanha, conforme analisado anteriormente, a redução de emissões soma-se ao fim do uso de energia nuclear como estratégias da transição energética em curso no país. Na Suécia, a energia nuclear representou mais de 40\% da geração total nos anos de 2013 e 2014; pelos dados da Figura 26, essa participação não tem apresentado tendência clara de redução. E, de fato, não é parte do planejamento do governo sueco a eliminação gradativa dessa fonte.

Segundo Hultman et al. (2012), para um período previsível do futuro, a energia nuclear continuará representando grande parte do sistema energético sueco. Mesmo com um referendo em 1980 que decidiu pela moratória de novos empreendimentos e pelo fechamento das usinas nucleares até 2010, pouco esforço foi feito nesse sentido. Ao longo do tempo, alguns reatores foram fechados, em um processo que envolveu interesses econômicos e negociações políticas. Em 2007, conforme descrito por Kaberger (2007), o governo afirmava que não seria tomada decisão explícita no sentido do fechamento de mais plantas. No ano de 2016, foi noticiada a decisão do governo sueco de construir novos reatores no lugar de outros que estão sendo 
desligados, além do corte de um imposto que tornava a energia nuclear menos competitiva; no entanto, é uma meta do governo ter toda a geração de energia elétrica do país de fontes renováveis até 2040 (DICKSON; ADOMATIS, 2016; MILNE, 2016).

Assim, compreende-se que não há, no curto prazo, a estratégia de eliminar a energia nuclear da geração elétrica sueca. Ainda, também diferentemente do caso alemão, a matriz da Suécia é pouco dependente de fósseis. Esses fatores, além da disponibilidade de outras fontes de biomassa e da fonte eólica no setor elétrico, podem ter direcionado o espaço do biogás para outro setor, o de combustível veicular.

O setor de transportes na Suécia, por sua vez, tem suas próprias ambições de transformação energética. Segundo Larsson, Gronkvist e Alvfors (2016), o biogás faz parte de estratégias de sustentabilidade ambiental que incluem, por exemplo, a visão do governo sueco de uma frota veicular independente de combustíveis fósseis até 2030.

A estratégia de direcionar o biogás para a produção de gás veicular na Suécia, de acordo com a avaliação de Larsson, Gronkvist e Alvfors (2016), não apresentou grande influência da presença de rede de gás natural. Mesmo sem acesso a essa infraestrutura, a utilização de caminhões para transporte do gás permitiu o desenvolvimento do uso do biometano em veículos e pode não ser necessária, mas a presença de gás natural é importante como backup. No entanto, considera-se que outro tipo de infraestrutura é importante para a difusão para o mercado de carros privados: a disponibilidade de estações de abastecimento com gás veicular (LARSSON; GRONKVIST; ALVFORS, 2016).

Portanto, compreende-se da experiência da Suécia que, ponderado o fato de ser um país pouco populoso e cuja produção de biogás é pequena, a possibilidade de produção de biometano como foco de um sistema é factível. Os incentivos com esse propósito direcionaram o consumo do biogás como combustível veicular. A flexibilidade do biogás permitiu, em um país que tem outras alternativas e não apresenta urgência para uma transição na produção de energia elétrica, que fosse utilizado em um setor em que a disponibilidade de energias renováveis é mais escassa.

Faz-se a ressalva de que o modelo sueco - assim como o alemão - pode ter dificuldades de ser replicado no Brasil, considerando-se as diferenças entre os países nos sistemas de coleta e tratamento de resíduos, no setor energético e na capacidade de planejamento e instrumentalização de políticas públicas. 


\section{COMPARAÇÃO ENTRE ENERGIA ELÉTRICA E BIOMETANO PARA O BRASIL}

A proposta principal desta dissertação é a comparação entre a produção, a partir do biogás, de energia elétrica e a de biometano. Pretende-se realizar uma análise suficientemente abrangente do tema, que permita abordar os diversos aspectos e características relevantes às duas estratégias de uso do biogás.

Sob o ponto de vista do setor energético e da sociedade e, portanto, condizentes com o interesse do país e não de atores específicos, a comparação deve ser capaz de identificar os benefícios e as desvantagens de cada estratégia, ou seja, as forças e fraquezas dentro do contexto atual e dos cenários futuros.

Para cumprir este objetivo, a definição dos critérios utilizados para a comparação é importante, pois indica quais aspectos serão analisados, delimitando o escopo do trabalho. Este se torna, portanto, um dos pontos decisivos para garantir a imparcialidade e, consequentemente, a relevância da pesquisa. A inclusão ou exclusão de critérios e de análises sem o devido mérito pode deslocar os resultados.

Portanto, buscou-se fundamentar a metodologia desta comparação utilizando critérios que norteiam decisões no setor energético, na teoria e na prática, visando ao interesse público. Essa intenção pode ser expressa na definição, por Pinto Jr. et al. (2007, p. 292), de "política energética":

Uma intervenção estratégica do Estado; abrangente - que envolve um conjunto de fontes, de cadeias energéticas, de instrumentos e instituições -, visando a garantir o suprimento, presente e futuro, de energia necessário ao desenvolvimento econômico e ao bem-estar de uma sociedade.

Assim, a identificação de critérios para a comparação pretendida neste trabalho será baseada no conceito de "política energética", expresso sucintamente na frase anterior, e descrito em Pinto Jr. et al. (2007) ${ }^{11}$. Além dessa referência teórica, exemplos de documentos de política energética dos Estados Unidos, da União Europeia e do Brasil serão utilizados, contribuindo com experiência prática de formulação de políticas energéticas, seus pilares e aplicação. Por fim, os critérios comuns encontrados podem ser analisados em sua flexibilidade e coerência

\footnotetext{
${ }^{11}$ Capítulo 5, Seção 5.1: "Visão conceitual de política energética: O papel do Estado e objetivos”.
} 
com os objetivos deste trabalho, para que possam ser adaptados à proposta de comparação dos usos do biogás no Brasil.

Portanto, a comparação proposta aqui é considerada uma análise, com o objetivo de tomada de decisão, entre as inúmeras que podem fazer parte de uma política energética. $\mathrm{Ou}$ seja, dentro do "leque de opções energéticas e tecnológicas que requerem dos formuladores de política um processo cuidadoso de tomada de decisões” (PINTO JR. et al., 2007), a análise das formas de utilização de biogás e a escolha de um "uso prioritário" poderia ser uma das diversas questões a serem decididas.

Os critérios a serem utilizados para análise serão selecionados, por este autor, a partir das referências citadas. Não se pretende, por óbvio, redefinir "política energética", nem estabelecer definitivamente os critérios mais importantes de uma; apenas foram aproveitados instrumentos, interpretados por este autor, para desenvolver uma metodologia para este trabalho.

\subsection{Identificação dos critérios para comparação}

Nesta seção, estão apresentados os trabalhos utilizados para seleção dos critérios para a comparação a ser realizada. Especialmente para selecioná-los da definição teórica, de Pinto Jr. et al. (2007), foi necessário filtrar e interpretar o texto, o que, portanto, tem um resultado subjetivo. Nos casos das políticas energéticas dos países, os critérios apareceram mais claramente. Buscou-se reproduzir os argumentos para a escolha de cada critério, sendo destacado em itálico as palavras-chave de cada um.

- Definição teórica

Uma política energética é abrangente e exige uma "abordagem ampla, completa e integrada", envolvendo "ações e impactos em diferentes áreas: econômica, tecnológica, ambiental, política e social", agregando ainda políticas de desenvolvimento, tributária e industrial, entre outras (PINTO JR. et al., 2007).

A garantia de suprimento, segundo Pinto Jr. et al. (2007) o "objetivo essencial" de qualquer política energética, tem como uma das principais estratégias a diversificação do abastecimento, que gera uma redução nos riscos (PINTO JR. et al., 2007).

Ainda, o preço a ser pago para garantir o suprimento deve ser "razoável", mesmo que esse patamar seja de "difícil definição". O conceito de garantia também pressupõe que haja uma estabilidade de preços, para que seja possível para o consumidor prever investimentos em ativos 
que utilizam energia. Por ser um insumo essencial de várias atividades, os preços da energia afetam os índices de preço de toda a economia, que, por sua vez, influenciam os níveis de inflação e, consequentemente, as taxas de juros. A disponibilidade e os preços da energia também podem ser diretamente responsáveis pela viabilidade de investimentos e pela competitividade regional em um contexto global (PINTO JR. et al., 2007).

Pinto Jr. et al. (2007) também destaca o "papel fundamental” da infraestrutura energética como condição estrutural para o desenvolvimento econômico. Os investimentos nessa área ainda seriam determinantes do montante de investimentos do país, por ser intensiva em capital.

A quantidade de produção de energia nacional também tem forte relação com a economia: o balanço entre importações e exportações desse insumo pode se relacionar "com a disponibilidade de divisas e, portanto, com o comportamento do câmbio". A política energética brasileira, segundo Pinto Junior et al. (2007), tem se caracterizado pela busca pela redução da dependência de energia importada.

A política ambiental é apontada como fundamental na definição de uma política energética, pela forte correlação entre ambas pelos impactos locais, nacionais e globais da produção e do uso da energia (PINTO JR. et al., 2007).

São também destacadas questões do lado da demanda, sociais, tecnológicas, geopolíticas, entre outras, que foram avaliadas como não tendo relação direta consistente com o objetivo deste trabalho.

\section{- Política energética da União Europeia}

A política energética da União Europeia (UE), de acordo com a publicação "An energy policy for Europe" da European Commission (2007), tem três desafios principais: sustentabilidade, segurança do suprimento e competitividade. Segundo Kanellakis, Martinopoulos e Zachariadis (2013), essa publicação identificou esses pilares, marcando o início do plano de ação europeu e possibilitando a definição de metas quantificáveis, como a famosa 20/20/20 - até 2020, a meta da UE é de redução de 20\% em emissões de GEE em relação a 1990, de ter $20 \%$ da energia de fontes renováveis e de melhoria de $20 \%$ em eficiência energética.

A European Commission (2007) explica cada um dos três desafios apontados. Em relação à sustentabilidade, afirma que a energia está na raiz das mudanças climáticas e da maior parte da poluição do ar. Para o desafio de segurança do suprimento, a preocupação principal era com o aumento da dependência de hidrocarbonetos importados e os consequentes riscos políticos, 
econômicos e de falha no suprimento; apontam também a dependência de um fornecedor de gás - a Rússia, cuja relação com a UE é tratada como prioridade no documento. A competitividade, por sua vez, preocupava pela volatilidade e aumentos nos preços, e notava-se a importância de investimentos em eficiência energética e em energias renováveis, que estimulariam também a inovação e a geração de empregos.

- Política energética dos EUA

Os Estados Unidos da América (EUA), durante a administração do presidente Barack Obama, publicaram o documento "Blueprint for a secure energy future", mostrando uma estratégia de três partes para o país no setor energético: desenvolver e garantir o suprimento energético americano, dar aos consumidores alternativas para reduzir custos e economizar energia, e inovar em busca de um futuro de energias limpas (THE WHITE HOUSE, 2011).

O documento aponta para a necessidade de desenvolver ativos, inovação e tecnologia dentro do país para aumentar a oferta nacional de energia, sendo enfático em relação ao aumento da produção de petróleo. O desenvolvimento de combustíveis alternativos, a obtenção de um suprimento de energia diversificado e a liderança em energias limpas são considerados “críticos" para fortalecer a economia do país. Outro foco é em medidas para aumentar a eficiência do uso de energia (THE WHITE HOUSE, 2011).

Em 2014, ainda sob Obama, os EUA lançaram outro documento de política energética, o "The all-of-the-above energy strategy as a path to sustainable economic growth". São apontados três elementos chave da estratégia, similares, mas colocados de forma diferente dos de 2011: aumentar a segurança energética, apoiar o crescimento econômico e a criação de empregos, e desenvolver tecnologias de baixo carbono fornecendo os fundamentos para um futuro de energias limpas (THE WHITE HOUSE, 2014). Mais uma vez, portanto, os elementos garantia do suprimento, a dimensão econômica e a redução dos impactos ambientais são destaque em um plano, na prática, de um país.

- Política energética brasileira

No Brasil, a EPE publicou "O compromisso do Brasil no combate às mudanças climáticas: produção e uso de energia", para apresentar os cálculos que subsidiaram as propostas relacionadas ao setor energético contidas na Intended Nationally Determined Contribution (iNDC, ou Pretendida Contribuição Nacionalmente Determinada, em português). A iNDC foi apresentada como a proposta do país para buscar um acordo sobre mudanças 
climáticas durante a COP21, que resultou no Acordo de Paris, ratificado pelo governo brasileiro (EPE, 2016b).

Nesse documento, foi apresentado um trilema a ser equilibrado na expansão do setor elétrico brasileiro. Segundo a EPE (2016b), "o desafio de constituir a futura matriz de geração elétrica brasileira compreende atender à demanda de eletricidade de forma segura, com o menor custo possível e levando em consideração as políticas e os compromissos de proteção ambiental e social". A Figura 28 ilustra o trilema.

Figura 28. Trilema considerado na estratégia de expansão do setor elétrico brasileiro

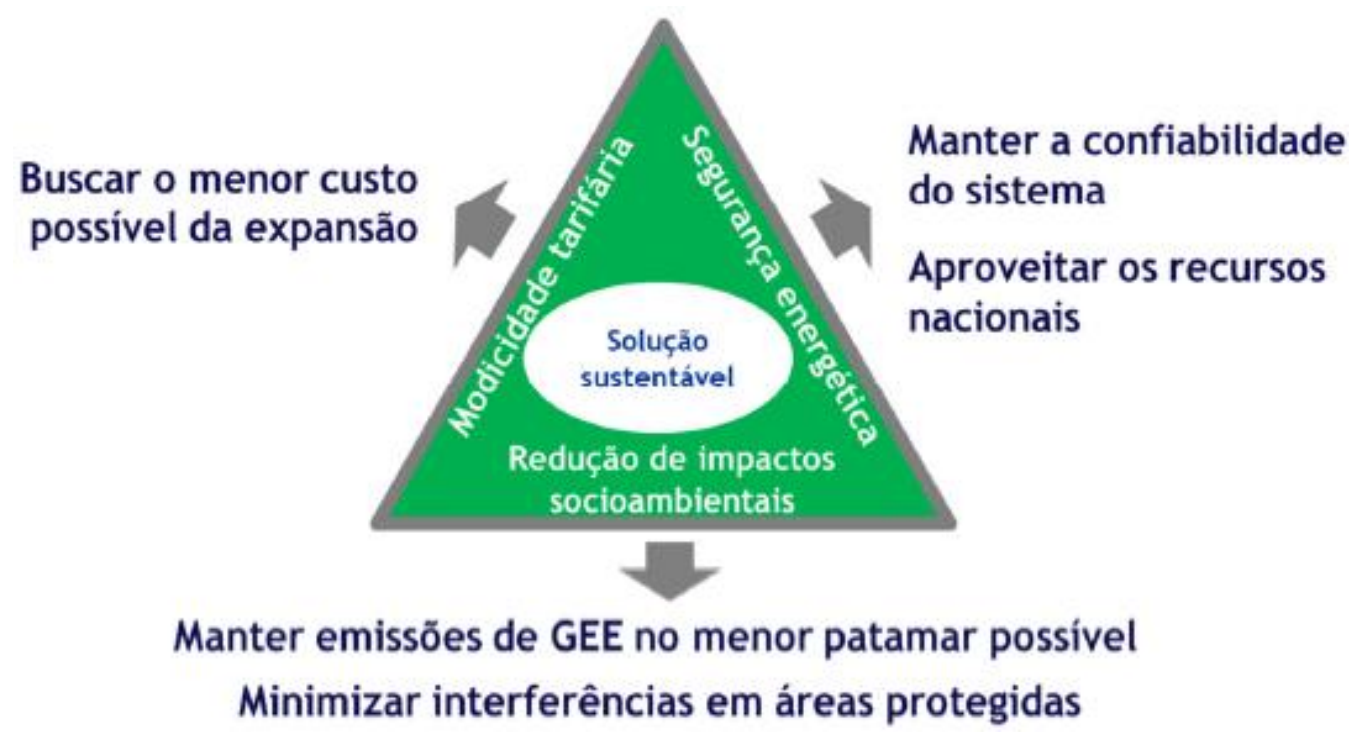

Fonte: EPE (2016b).

Portanto, a diretriz brasileira, restrita nesse caso ao setor elétrico, conforme a Figura 28, apresenta três aspectos principais: modicidade tarifária; segurança energética, relacionada à confiabilidade do sistema e ao aproveitamento de recursos nacionais; e a redução de impactos socioambientais, associada à redução de emissões de GEE e à minimização de interferências em áreas protegidas (EPE, 2016) - esta última uma característica importante para a expansão da hidroeletricidade no Brasil.

- Identificação e definição dos critérios

Comum aos casos da UE, dos EUA e do Brasil, portanto, são três dimensões principais: a segurança no abastecimento, e as dimensões econômica e ambiental. Todas estão correlacionadas, e podem ser desmembradas em outros aspectos, concordando com os cinco principais critérios identificados na definição teórica. 
$\mathrm{Na}$ análise apresentada, a questão ambiental tem como ponto principal a preocupação com as emissões de GEE, e o desenvolvimento de fontes renováveis e a eficiência energética aparecem como as principais soluções. A questão econômica tem o foco na questão do custo da energia; no entanto, tem forte correlação com a dimensão da segurança no abastecimento. Nestas duas dimensões, destacam-se ainda o desenvolvimento de recursos nacionais, reduzindo a dependência externa e fortalecendo a economia local; a diversificação de fontes e tecnologias, com foco na segurança energética e no desenvolvimento da economia; e a confiabilidade do sistema, em termos mais abstratos, mas que pode ser compreendida como a disponibilidade de infraestrutura que combine todos os elementos ditos anteriormente, garantindo o suprimento de energia de forma econômica e segura.

Identifica-se, portanto, os cinco critérios a serem analisados neste trabalho:

i. Segurança no abastecimento e diversificação de fontes;

ii. Modicidade e estabilidade dos preços de energia;

iii. Balança de importações e exportações;

iv. Infraestrutura energética;

v. Aspectos ambientais.

\subsection{Uso dos critérios e forma de comparação}

A comparação será realizada buscando compreender a oportunidade que cada uso do biogás traz para o sistema energético nesses aspectos, e se encontra dificuldades em algum dos

critérios. É, portanto, uma combinação entre as características que a energia do biogás tem considerando a produção de energia elétrica ou de biometano - e o contexto do setor energético. A análise da experiência internacional, realizada na Seção 4.3, permitiu a compreensão da importância desse contexto para o desenvolvimento do biogás.

Ou seja, nas Seções 5.3 a 5.7 será analisado como o biogás pode contribuir, ao gerar energia elétrica, na diversificação de fontes, na modicidade e estabilidade dos preços de energia, na balança de importações e exportações, na infraestrutura energética e em aspectos ambientais. Ao mesmo tempo, como cada um desses aspectos cria oportunidades ou atrapalha o desenvolvimento do uso do biogás como energia elétrica no país. Da mesma forma, essa análise será feita para a produção de biometano a partir do biogás. 
Destaca-se, porém, que a complexidade natural da abrangência de uma política energética não a permite se resumir a uma escolha rígida e hierarquizada de objetivos, seja entre os aspectos da própria política energética ou no posicionamento desta entre as diferentes políticas envolvidas (PINTO JR. et al., 2007). Há de se compreender que, além da dificuldade técnica, as escolhas estão submetidas a uma administração política. Uma intervenção política, ainda segundo Pinto Jr. et al. (2007), é "fortemente marcada por concepções e visões do mundo". No entanto, os aspectos em si invariavelmente devem ser avaliados, como alguns apresentados nesta seção, mesmo que a importância relativa de cada um não seja um consenso.

Assim, não se buscou quantificar a importância - peso - de cada critério. Considera-se que esta é uma “definição política e de momento", como apresenta Pinto Jr. et al. (2007). Tratase de mercados diferentes, com contextos, fontes concorrentes, e formas de organização da indústria diferentes, que dificultam a quantificação dos critérios e uma comparação objetiva entre eles no formato proposto.

Neste trabalho é realizada uma comparação qualitativa, buscando apresentar uma visão geral em cada critério, usando dados consolidados e projeções do planejamento governamental. Busca-se identificar as oportunidades que a energia do biogás pode trazer e as dificuldades que enfrenta em suas diferentes formas de utilização, ou seja, os pontos positivos e negativos das alternativas biometano e energia elétrica. Um aprofundamento de cada critério, além da possibilidade de cálculo de indicadores para cada um deles, é uma sugestão para um trabalho futuro, e não estão previstos no escopo deste trabalho.

\subsection{Segurança no abastecimento}

De acordo com Pinto Jr. et al. (2007), o objetivo de uma política energética é a garantia do suprimento de energia, "presente e futuro, necessário ao desenvolvimento e ao bem-estar". Embora essa definição envolva diversos aspectos, o aumento da segurança no abastecimento, ou seja, a diminuição do risco de não garantir o suprimento, tem como uma das principais estratégias a diversificação da oferta (Pinto Jr. et al., 2007).

Segundo Yergin (2014), a diversificação da oferta é uma "pedra fundamental" da segurança energética. Já em 1913, em meio à mudança da operação dos navios de guerra britânicos de carvão para petróleo, e a consequente preocupação com a dependência deste produto, então importado, o responsável pela decisão, Winston Churchill, afirmou: "Não 
devemos depender da qualidade de ninguém, do processo de ninguém, do país de ninguém, da rota de ninguém e do campo de ninguém" (YERGIN, 2014).

Nesse sentido, a diversificação da oferta também pode ser analisada sob diversos aspectos; um importador, por exemplo, pode reduzir seus riscos comprando de vários produtores - o aspecto de importações será analisado na Seção 5.5. Em um sistema fechado, ou com limitações de entrada externas, como sistemas elétricos nacionais, a diversificação pode significar a variedade de fontes primárias, de produtores a partir da mesma fonte, etc., para que o suprimento não dependa excessivamente de um fornecedor ou tipo de fornecimento.

Teoricamente, portanto, "para garantir o suprimento é necessário diversificá-lo". No entanto, condições específicas, como a grande disponibilidade de uma fonte, podem fazer com que seja desejável a concentração. “A diversificação não pode ser encarada como um bem em si”; para garantir o suprimento, é fundamental que se defina o grau de diversificação adequado (PINTO JR. et al., 2007, p. 298).

Sob esse conceito, serão consideradas as características do biogás e do contexto do setor energético brasileiro, para avaliar as possibilidades de contribuição à diversificação e à segurança do abastecimento nas formas de energia elétrica e de biometano.

No setor elétrico, como já avaliado na Seção 2.4, há uma diversidade de fontes renováveis com grande potencial no Brasil, com destaque para a fontes hidráulica, eólica e solar. Portanto, é racional que exista competição do biogás com essas fontes, apesar das outras externalidades positivas do tratamento de resíduos pela digestão anaeróbia.

Os custos atuais e as perspectivas das fontes concorrentes do biogás, além da percepção de potencial de grande escala, atrai, a elas, destaque e investimentos. Apesar da atual concentração do setor elétrico na fonte hidráulica, a expansão conta com opções renováveis que ajudam a garantir a segurança do suprimento de energia elétrica no país.

A oportunidade do biogás pode estar no apoio direcionado por suas outras externalidades positivas, mas também por se diferenciar em sua capacidade de geração de base, firme e previsível, e com a perspectiva de geração flexível e despachável.

Nesse ponto, a energia do biogás pode deixar de competir diretamente com outras renováveis para se tornar parte importante do balanceamento do sistema. Caso a expansão de fato seja voltada a um setor de baixo carbono, é uma oportunidade de ganhar espaço em relação a fontes fósseis utilizadas em termelétricas. 
As termelétricas têm participação importante no SIN fazendo o ajuste das variações hidrológicas no setor elétrico, seja a volatilidade interanual ou a sazonalidade intra-anual. Esta é uma variabilidade de horizonte maior, ou seja, de adaptação a longos períodos sem operar, podendo ser acionadas na ocorrência de escassez do recurso hídrico, funcionando como um seguro (TOLMASQUIM, 2016b).

A outra participação das termelétricas na segurança do abastecimento de energia elétrica é no atendimento à demanda horária. Há no setor elétrico brasileiro preocupação cada vez maior com essa questão, pelo aumento da participação de fontes não-controláveis, ou nãodespacháveis, no atendimento à carga (SILVA; NETO; SEIFERT, 2016). Isso se deve à expansão de renováveis intermitentes como a fonte eólica e solar associado à de hidroelétricas a fio d'água e a diminuição dos reservatórios, como forma de minimizar impactos socioambientais dos projetos. Assim, as termelétricas, especialmente a gás natural, são consideradas solução complementar à expansão da geração por renováveis intermitentes (TOLMASQUIM, 2016a; TOLMASQUIM, 2016b).

A flexibilidade de curto prazo é importante, por exemplo, para o atendimento do horário de ponta. EPE (2015b) avaliou que, somado a medidas de gerenciamento da carga e eficiência energética, a geração distribuída no horário de ponta no Brasil pode representar uma redução na carga do sistema entre 7000 e 9000 MW. O estudo indica que esse parque de geração é composto de geradores a óleo diesel e gás natural, este em menor quantidade e de forma restrita à infraestrutura e preço competitivo.

Nesse contexto, a bioenergia e o biogás, especificamente, além de serem reconhecidos para o atendimento da demanda de base, têm sido avaliados na capacidade de atender a essas novas necessidades, como foi apresentado para o caso alemão, na Seção 4.4.1.

Persson et al. (2014) afirmam que o biogás pode ser utilizado para facilitar a entrada de fontes renováveis variáveis e podem aumentar a produção de eletricidade em momentos de suprimento deficitário. Lambert (2017) avalia que a habilidade de controlar o momento da geração fará do biogás um complemento à geração renovável intermitente das fontes eólica e solar.

A determinação do papel que o biogás pode cumprir na segurança do suprimento é essencial para viabilizar essa fonte no setor elétrico diretamente. Deve-se estabelecer as limitações da geração distribuída do biogás comparada à geração termelétrica convencional, como a possibilidade de despacho centralizado. Assim, é possível avaliar os benefícios do 
esforço do enriquecimento a biometano e de seu transporte, que pode ser desperdiçado caso o destino final seja a geração termelétrica. Há ainda a necessidade de existirem os mecanismos de incentivo corretos para que a planta de biogás tenha combustível para ser utilizado em horário de ponta ou em momentos de déficit de geração por fontes intermitentes.

Arasto et al. (2017), mesmo afirmando que os motores e turbinas a gás utilizados na geração de energia elétrica a biogás tem rápido tempo de resposta, avaliam que tipicamente o biogás é consumido ao ser produzido ou apresenta pequena capacidade de armazenamento em baixa pressão, o que pode ser um empecilho para a função de complemento a renováveis intermitentes. Para os autores, a produção de biometano e o uso das redes de gás natural pode fornecer o "armazenamento" necessário e tornar o biogás mais importante nesse papel.

Portanto, mesmo que para que o resultado final seja a geração de energia elétrica, a produção de biometano pode ser uma etapa importante ou necessária para o objetivo de garantir a segurança no abastecimento. Novamente, essa resposta está de acordo com o sistema desenvolvido na Alemanha, que, conforme apresentado na Seção 4.4.1, concedeu a geradores que utilizam gás da rede o mesmo benefício (em tarifa feed-in) de um gerador a biogás, caso comprovada a aquisição de biometano na mesma quantidade.

Ainda considerando o uso do biometano para eletricidade, EPE (2015b), avaliando a geração no horário de ponta, sugere que se identifique o comportamento dos geradores distribuídos "para incentivar esquemas mais eficientes como a cogeração a gás natural" e avaliar a "possibilidade de substituição do diesel por combustíveis renováveis como o biodiesel e biometano, incentivando esses mercados".

No mercado de gás natural, por sua vez, o biometano poderia atender a demandas previsíveis e estáveis como, por exemplo, o consumo industrial. A característica da produção do biogás e de sua utilização no setor energético não tem a capacidade de suprir a variação interanual típica de grande parte da geração termelétrica a gás natural no Brasil, como foi apresentado na Seção 2.4 e na Figura 6 como um dos seus papeis.

\subsection{Preços: modicidade e estabilidade}

O preço da energia, conforme descrito na Seção 5.1, deve ser "razoável” e "estável” para atender ao conceito de segurança energética. Além ser decisivo na competitividade econômica e na viabilidade de investimentos, o fator social do acesso à energia requer modicidade tarifária. 
A energia, como insumo fundamental e condição para o desenvolvimento, precisa ser acessível em termos econômicos.

Acrescentando à modicidade, a estabilidade também é importante. Segundo Bordoff et al. (2009), choques no preço da energia podem ter impactos danosos ao reduzir o poder de compra dos consumidores e, consequentemente, a atividade econômica.

Há uma preocupação, por outro lado, que se os preços da energia forem muito baixos, o consumo será alto, contribuindo para as mudanças climáticas e outros efeitos negativos do consumo de energia. Para isso, o sinal econômico, ou seja, o preço, deve refletir os custos sociais. Uma forma de corrigir os preços para incorporar as externalidades é a adoção de impostos. A arrecadação no setor energético, segundo Pinto Jr. et al. (2007), representa fonte importante de receitas do governo; a formulação tributária também é um dos principais mecanismos de operacionalizar as intenções de uma política energética, ao fomentar ou desencorajar comportamentos relacionados à energia.

De qualquer forma, é desejável que sejam minimizados os custos de expansão e operação do sistema, considerando curto, médio e longo prazos. Na prática, para esta análise, a questão é avaliar a viabilidade do biogás comparando seus custos aos das fontes concorrentes, e as características financeiras que diferenciam a geração de energia elétrica da produção de biometano. Esta seção analisará as características de custo da geração de energia, sendo que os custos totais também dependem do transporte dessa energia até o consumidor - a infraestrutura de transporte da energia será analisada na Seção 5.4 .

Os custos da energia elétrica do biogás e do biometano incluem todas as etapas, ou seja, também envolvem os custos de produção do biogás. Assim, para que essas alternativas possam ser competitivas com outras fontes de energia, é importante avaliar a coleta dos resíduos e a digestão anaeróbia. A Figura 29 mostra os custos de produção de biogás por diferentes matériasprimas. 
Figura 29. Custos para a produção de biogás para diferentes matérias-primas e escalas de produção, em dólares (US\$) por $\mathrm{m}^{3}$ de metano

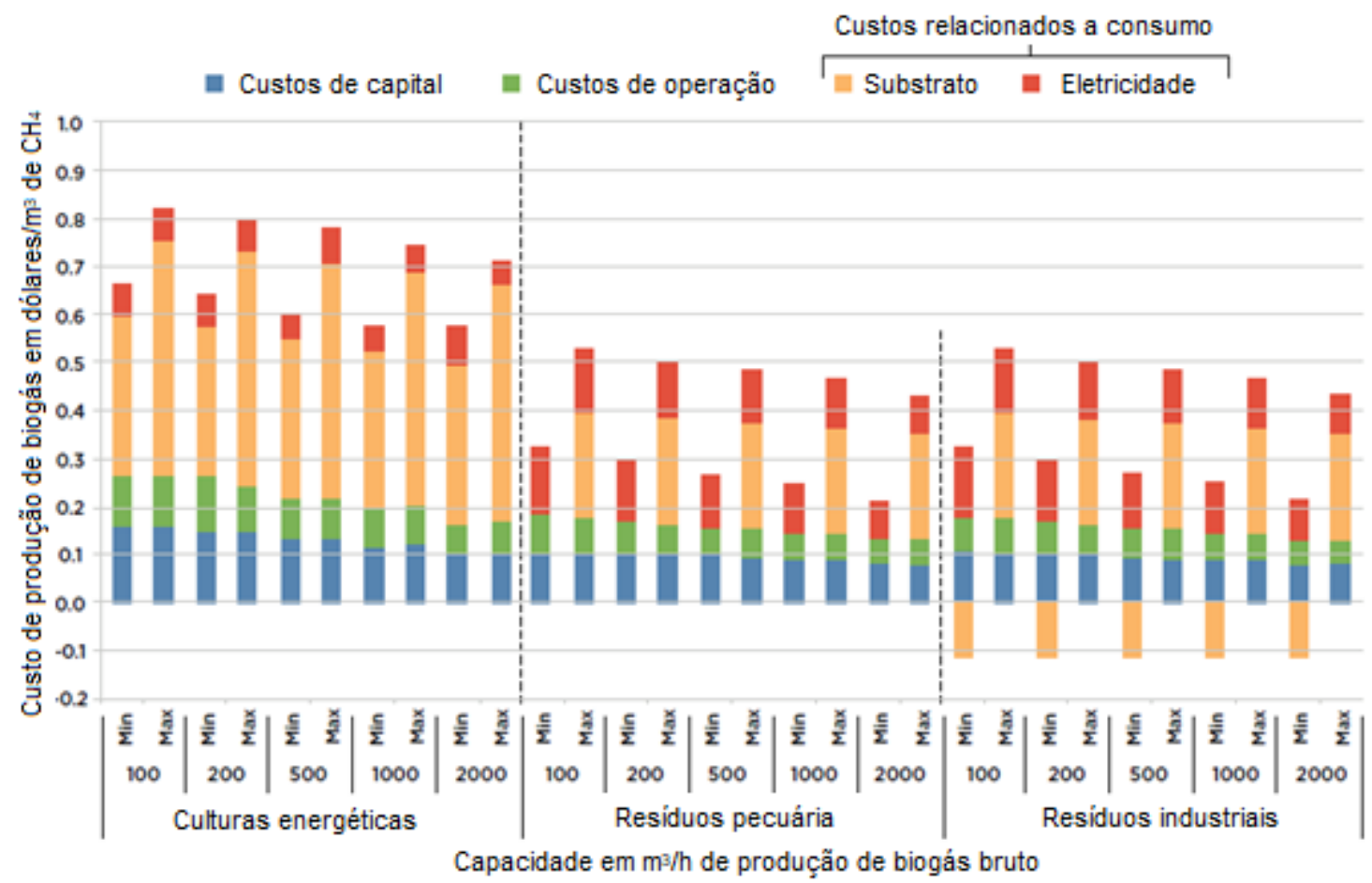

Fonte: adaptado de $\operatorname{Urban}^{12}$ (2009) apud IRENA (2017)

Nota-se, da Figura 29, que há redução de custos da produção de biogás com o aumento da escala. No entanto, mesmo com a diferença de $100 \mathrm{~m} / \mathrm{h}$ para $2000 \mathrm{~m} 3 / \mathrm{h}$, essa redução de custos, para essa etapa, não parece determinante na viabilidade do processo. Por outro lado, a matéria-prima utilizada e os custos mínimo e máximo, em uma mesma condição, são fatores que apresentam grande variabilidade entre si.

Portanto, certos resíduos podem ser mais viáveis que outros, e a especificidade caso-acaso é muito importante de ser analisada. Deve-se buscar, no potencial energético, as opções de maior viabilidade econômica para o desenvolvimento do setor. Nota-se que os dados da Figura 29 não correspondem ao caso brasileiro, e os custos indicados são suficientes apenas para a análise da influência dos fatores, como foi feito.

A avaliação do fator escala pode ser realizada para os processos de geração de energia elétrica e produção de biometano.

\footnotetext{
12 Urban, W. et al. (2009): Abschlussbericht für das BMBF-Verbundprojekt "Biogaseinspeisung" - Band 4 Technologien und Kosten der Biogasaufbereitung und Einspeisung in das Erdgasnetz. Ergebnisse der Markterhebung 2007-2008, Fraunhofer-Institut für Umwelt-, Sicherheits- und Energietechnik UMSICHT, Oberhausen
} 
Na geração de energia elétrica, Deublein e Steinhauser (2008) mostram que o custo de operação aumenta praticamente linearmente com a potência, e que o custo por potência instalada dos equipamentos de geração diminui quanto maior a escala. Dados de EPA (2007) corroboram com essa visão; os valores encontrados estão resumidos na Tabela 10. Na Figura 30, são mostrados os mesmos dados de EPA (2007) e um levantamento de Valente (2015) dos custos de instalação de motogeradores a partir do orçamento de diferentes fornecedores.

Tabela 10 - Custo específico de instalação de equipamentos de geração de energia elétrica ${ }^{13}$

\begin{tabular}{|l|c|c|}
\hline \multirow{2}{*}{ Equipamento } & \multicolumn{2}{|c|}{ Custo específico de instalação (por kW de potência) } \\
\cline { 2 - 3 } & Deublein e Steinhauser (2008) & EPA (2007) \\
\hline Motor a & $500 \mathrm{~kW}: \mathrm{R} \$ 1875 / \mathrm{kW}$ & $100 \mathrm{~kW}: \mathrm{R} \$ 2813 / \mathrm{kW}$ \\
combustão & $1500 \mathrm{~kW}: \mathrm{R} \$ 1459 / \mathrm{kW}$ (de gráfico); & $300 \mathrm{~kW}: \mathrm{R} \$ 2406 / \mathrm{kW}$ \\
interna & Não especificada: de R \$ 3750 a R $\$$ & $1000 \mathrm{~kW}: \mathrm{R} \$ 2250 / \mathrm{kW}$ \\
& $4063 / \mathrm{kW}$ & $3000 \mathrm{~kW}: \mathrm{R} \$ 1781 / \mathrm{kW}$ \\
& & $5000 \mathrm{~kW}: \mathrm{R} \$ 1719 / \mathrm{kW}$ \\
\hline Microturbina & $30-110 \mathrm{~kW}: \mathrm{R} \$ 1875-2813 / \mathrm{kW}$ & $100 \mathrm{~kW}: \mathrm{R} \$ 4219 / \mathrm{kW}$ \\
& & $250 \mathrm{~kW}: \mathrm{R} \$ 3438 / \mathrm{kW}$ \\
\hline
\end{tabular}

Fonte: elaborado a partir das referências indicadas na tabela.

${ }^{13}$ Aplicado câmbio comercial de R \$ 3,12 para US\$ 1,00, de 04 de agosto de 2017 (BANCO CENTRAL DO BRASIL (2017) 
Figura 30. Custo de investimento em motogeradores para diferentes faixas de potência ${ }^{14}$

a)

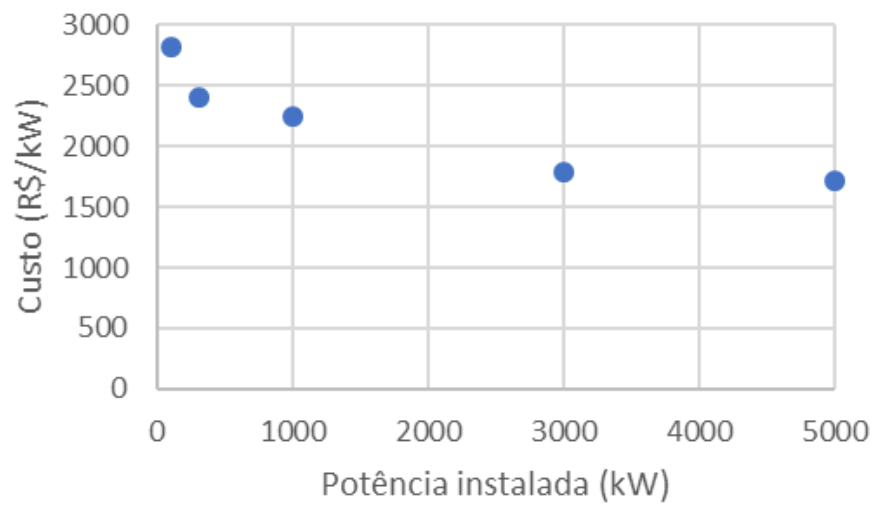

b)

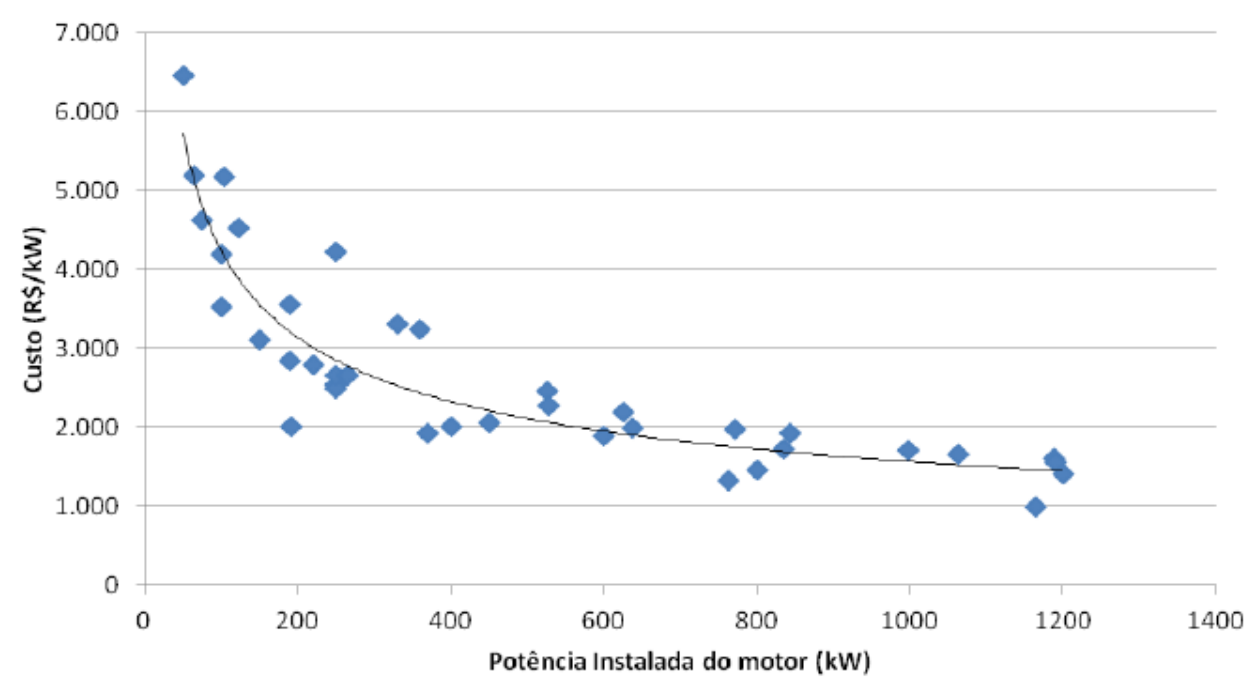

Fonte: a) elaborado a partir de EPA (2007); b) Valente (2015).

Os valores evidenciam que, para escalas muito pequenas, menores que $200 \mathrm{~kW}$, os custos por unidade de potência são relativamente altos. Os ganhos expressivos com o aumento da escala, no entanto, são limitados na instalação de equipamento de geração de energia elétrica com biogás, como mostram os dados de EPA (2007) e Valente (2015). Nota-se da Figura 30 especialmente em b) - que, a partir de certa potência, o custo específico (por kW) não apresenta diminuição significativa.

Ainda, em unidades de grande porte, muitas vezes de capacidade maior que os limites dos motores, é comum que sejam combinados mais de um motogerador; portanto, nesses casos, o

\footnotetext{
${ }^{14}$ Para comparação entre as escalas da Figura 29 e Figura 30: adotando poder calorífico superior (PCS) do metano de 39,7 MJ, concentração de metano no biogás de $60 \%$, e eficiência elétrica do gerador de $38 \%$ em relação ao PCS, $1 \mathrm{~m}^{3}$ de biogás é capaz de gerar 2,5 kWh de eletricidade [FNR (2013) adota de 1,9 a 3,2 kWh $\mathrm{kW}_{\mathrm{el}}$; portanto, nesse caso, $500 \mathrm{~kW}$ de potência equivale a uma planta que consome $200 \mathrm{~m}^{3} / \mathrm{h}$ de biogás. Mantida a eficiência (que pode, no entanto, aumentar com a escala), a proporção seria linear; ou seja, $250 \mathrm{~kW}$ equivale a $100 \mathrm{~m}^{3} / \mathrm{h}$ e 1000 $\mathrm{kW}$ equivale a $400 \mathrm{~m}^{3} / \mathrm{h}$.
} 
aumento dos custos com os equipamentos de geração seria linear. No aproveitamento do biogás de aterro da usina Termoverde Caieiras, por exemplo, que tem capacidade instalada de cerca de 30 MW, há 21 conjuntos motogeradores instalados (VALOR, 2016), enquanto o Aterro Bandeirantes tem 24 motores de $925 \mathrm{~kW}$ cada, somando 22,2 MW (PAVAN, 2010). A montagem em módulos contribui para a flexibilidade da planta em termos da geração de biogás, importante em aterros sanitários com recebimento de resíduos encerrado, por exemplo.

O sistema alemão de remuneração da energia por tarifas feed-in reconhecia a diferença entre as plantas de pequeno porte e as maiores; os incentivos eram desenhados em várias classes dependendo do porte da planta, com os incentivos sendo até cerca de quatro vezes maior para as unidades de menor capacidade instalada (FNR, 2013)

Os resultados dos custos de geração de energia elétrica com biogás são, assim como os da própria produção de biogás, muito variáveis. A Tabela 11 mostra a estimativa de custos encontrados para diferentes matérias-primas.

Tabela 11 - Estimativas de custo de geração de energia elétrica com biogás

\begin{tabular}{|c|c|c|}
\hline Referência & Matéria-Prima & Custo/MWh e obserações \\
\hline EPE (2014) & $\begin{array}{l}\text { Resíduos sólidos } \\
\text { urbanos }\end{array}$ & Entre R\$ 515/MWh a R \$260/MWh (com incentivos) \\
\hline EPE (2014) & Resíduos rurais & $\begin{array}{c}\mathrm{R} \$ 341,32 / \mathrm{MWh} \text { a } \mathrm{R} \$ 291,67 / \mathrm{MWh} ; \mathrm{R} \$ 278,04 \text { a } \mathrm{R} \$ \\
\text { 225,50/MWh, com venda de biofertilizante }\end{array}$ \\
\hline Poveda (2014) & Vinhaça & $\begin{array}{c}\mathrm{R} \$ \text { 540/MWh (cenário conservador, 1,3 MW) e R } \$ \\
\text { 240/MWh (cenário otimista, 3,36 MW) }\end{array}$ \\
\hline Valente (2015) & Esgoto & $\begin{array}{l}\mathrm{R} \$ 488 / \mathrm{MWh} \text { (pior cenário, escala de } 100.000 \text { habitantes); } \\
\mathrm{R} \$ 151,00 \text { (melhor cenário, } 450.000 \text { hab.) }\end{array}$ \\
\hline
\end{tabular}

Fonte: elaborado a partir das referências indicadas.

Portanto, os custos da geração de energia elétrica a partir do biogás são muito variáveis. Para comparação entre os custos de geração de energia elétrica de diferentes fontes para o Brasil, Pereira Jr. et al. (2013) consideraram uma planta de $30 \mathrm{MW}$, ou seja, de grande porte, com custos de instalação de US\$2400/kW e fator de capacidade de 50\%. Utilizando uma taxa de desconto de $12 \%$, os resultados encontrados estão apresentados na Figura 31. 
Figura 31. Composição dos custos de geração para diferentes fontes

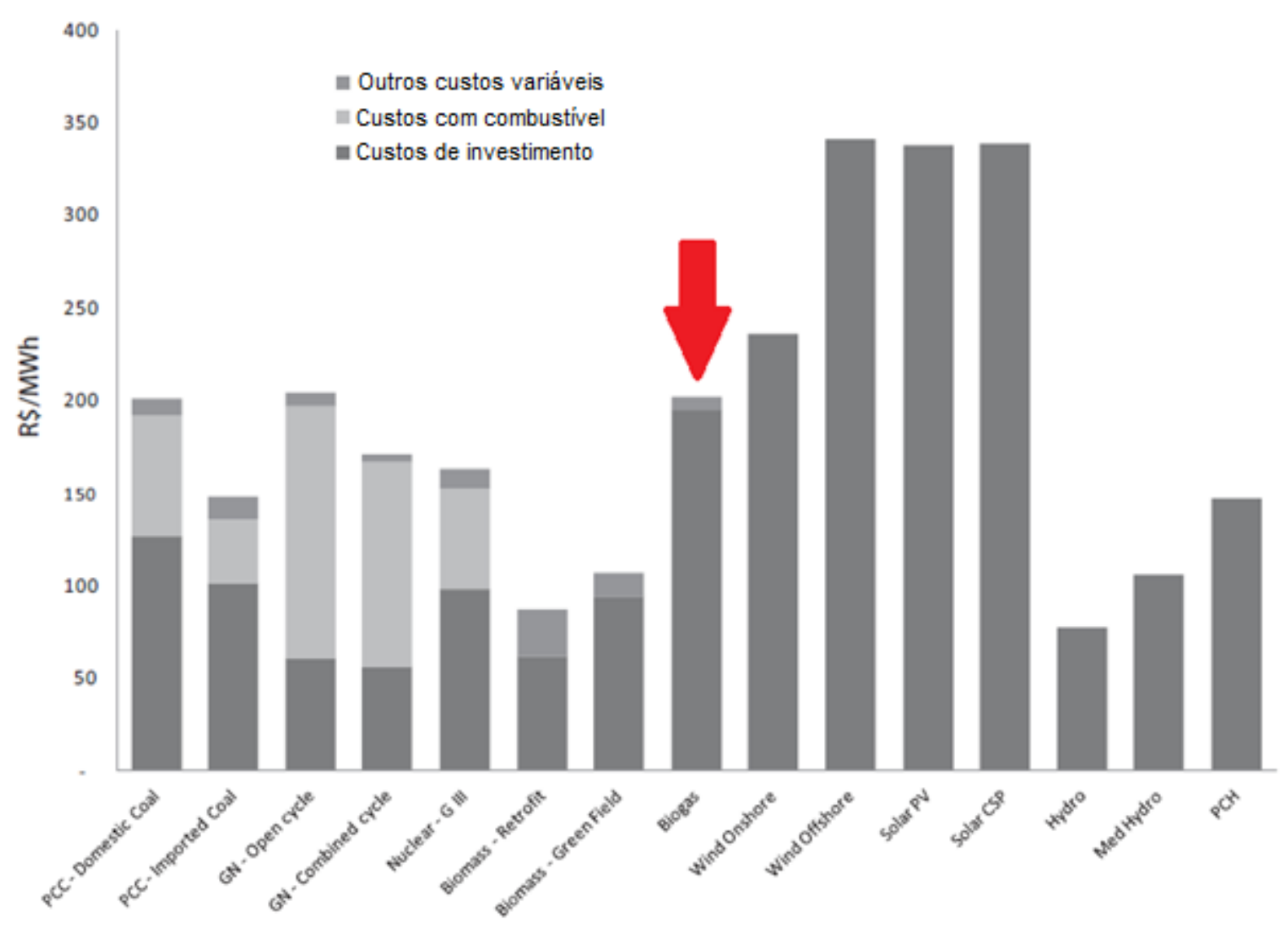

Fonte: adaptado de Pereira Jr. et al. (2013).

Nota-se, para o caso estudado, que a geração de energia elétrica pelo biogás é competitiva com outras fontes renováveis. No entanto, Pereira Jr. et al. (2013) chamou a atenção para a estimativa de que os custos das fontes eólica e solar cairiam nos anos seguintes, corroborando com as perspectivas e a viabilidade atual da energia eólica - demonstrada pelo aumento de capacidade instalada e pelos preços de venda em leilões ${ }^{15}$ - e a visão apresentada em EPE (2014c) para a redução de custos energia solar fotovoltaica.

Novamente, em comparação com outras fontes renováveis, faz sentido que a capacidade de gerar energia de forma previsível e sua flexibilidade ao despacho seja aproveitada pelo setor energético, e que esse fator possa ser remunerado de maneira adequada. Ainda, os benefícios

\footnotetext{
${ }^{15}$ No $22^{\circ}$ Leilão de Energia Nova A-3, realizado em agosto de 2015, o Índice de Custo Benefício (ICB) para os empreendimentos contratados da fonte eólica esteve na faixa entre $\mathrm{R} \$ 178,88$ e $\mathrm{R} \$ 182,42$, somando $538 \mathrm{MW}$ contratados (CCEE, 2015), enquanto no $23^{\circ}$ Leilão de Energia Nova A-5, realizado em abril de 2016, apenas um empreendimento a biogás, de 20,9 MW, foi contratado pelo ICB de R\$251,00 (CCEE, 2016) - valores da época dos leilões. Atualizando os valores da eólica para abril de 2016 pelo IPC-A, a faixa seria de R \$ 191,33 a R \$ 195,12.
} 
da geração distribuída, como os impactos na necessidade de infraestrutura, podem ser avaliados para os incentivos a viabilizar a geração de eletricidade por biogás em menor escala.

A produção de biometano, por sua vez, tende a ser realizada apenas em unidades de grande porte, devido aos altos custos de investimento e operação (FNR, 2013). A Figura 32 mostra o custo total de biometano desde a produção até a distribuição do gás.

Figura 32. Custos para o fornecimento de biometano, em dólares (US\$) por metro cúbico, para diferentes matérias-primas e escalas de produção

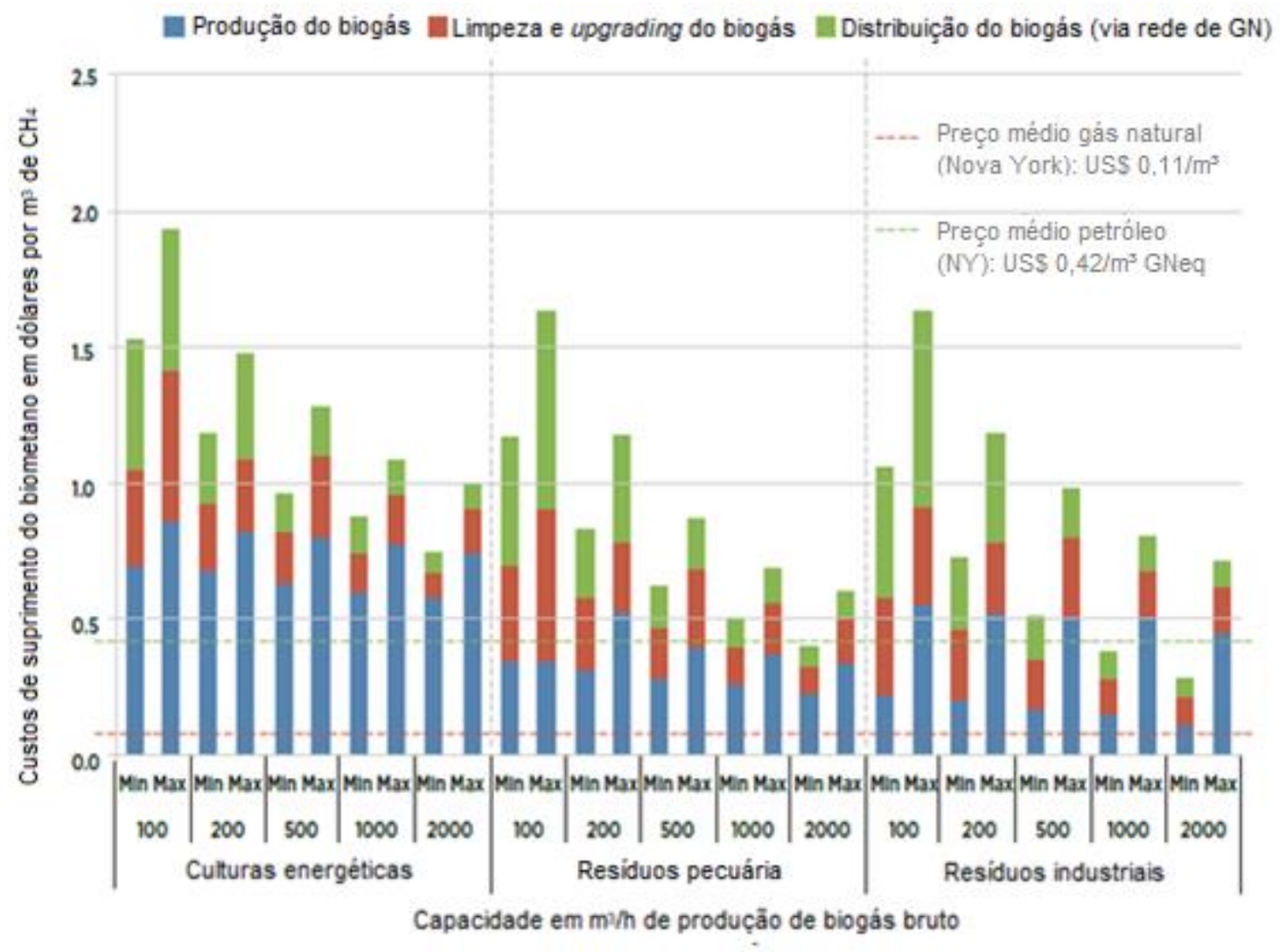

Fonte: adaptado de IRENA (2017).

A Figura 32 revela que o custo de produção do biogás é muito importante no custo total do biometano; a não ser nas menores escalas, representa mais de 50\% do total. Os custos de tratamento e distribuição do gás apresentam acentuada redução de custo com o aumento da escala, tornando-se menores proporcionalmente. Novamente, nota-se que os casos de custo mínimo e máximo têm valores muito discrepantes, principalmente devido ao custo de produção do biogás, que pode sofrer grandes variações, como já foi discutido. 
Portanto, para a viabilidade da produção de biometano, é importante que exista grande potencial energético localizado, pois em escalas pequenas e médias os custos são muito maiores. Os cálculos de Leme e Seabra (2017), apresentados na Figura 33, também apontam nesse sentido.

Figura 33. Impacto da escala no custo específico do biometano produzido do biogás de vinhaça

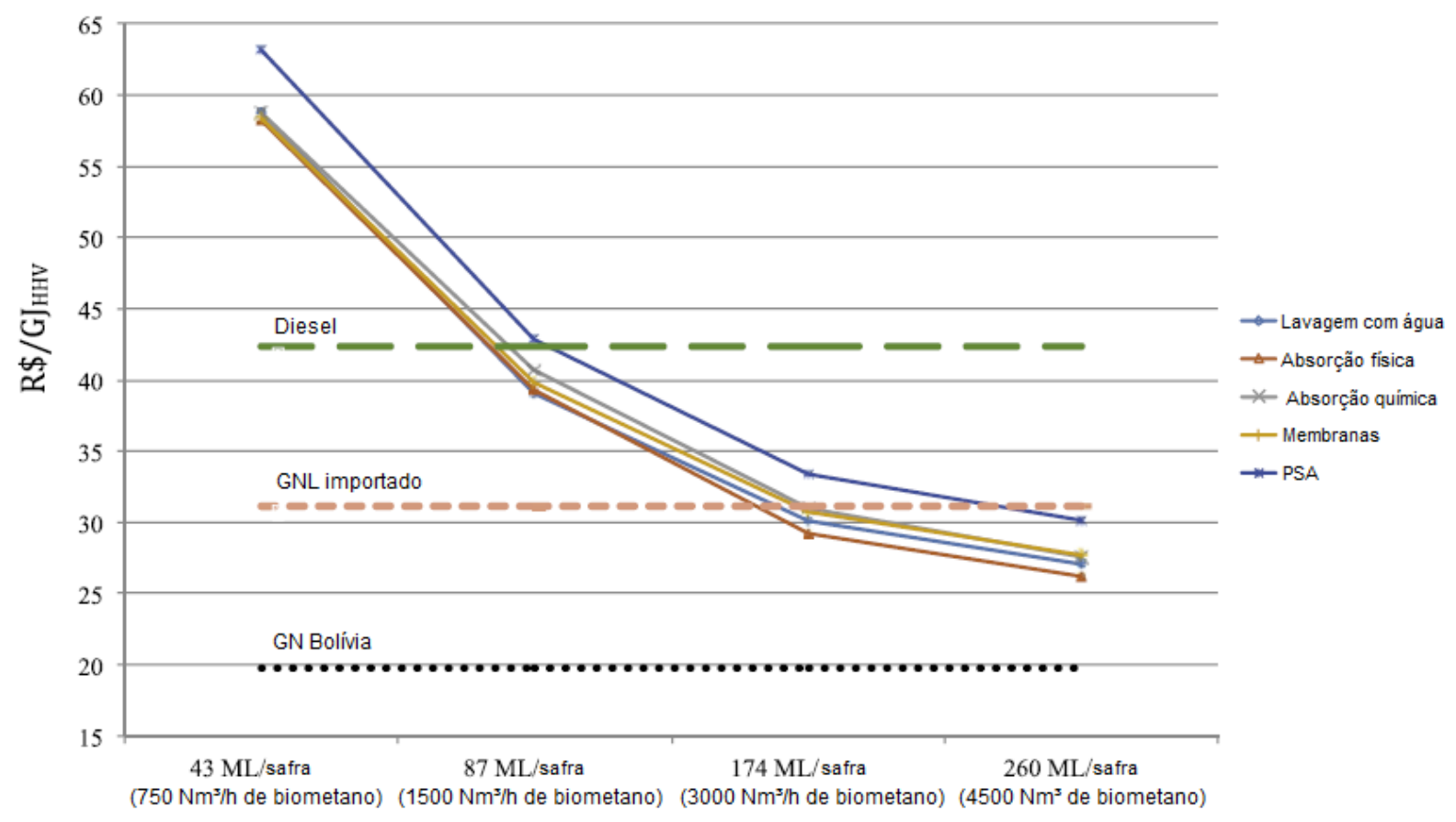

Fonte: adaptado de Leme e Seabra (2017).

A Figura 33 mostra que o biometano produzido a partir da vinhaça em escala de cerca de $1500 \mathrm{Nm}^{3} / \mathrm{h}$ pode ser competitivo com o diesel, enquanto em $3000 \mathrm{Nm} / \mathrm{h}$ com o gás natural liquefeito (GNL) importado. Essa descoberta é importante, pois, como será avaliado na Seção 5.5, o Brasil tem se utilizado da importação de GNL para suprir parte da demanda interna de gás natural; assim, o biometano se mostra uma alternativa viável, de produção local e renovável.

Ressalva-se o fato de que a escala de $3000 \mathrm{Nm}^{3} / \mathrm{h}$ de biometano é muito grande; corresponderia a uma planta de cerca de $5000 \mathrm{Nm}^{3} / \mathrm{h}$ de biogás ou $12 \mathrm{MW}$ de capacidade instalada. Essa capacidade de produção pode ser encontrada, além da vinhaça, em aterros sanitários de grandes centros urbanos - no Brasil há projetos com capacidade instalada de geração elétrica maiores que essa, como a já citada Termoverde Caieiras e outras plantas que serão vistas na Seção 6. Os dados da Figura 33 revelam que a redução de custos continua com o aumento para escalas ainda maiores. 
A avaliação de EPE (2014b) é que, no caso-base analisado na produção de biometano de resíduos sólidos urbanos, para uma planta de $190 \mathrm{~m} 3 / \mathrm{h}$, a tarifa de equilíbrio do biometano seria $\mathrm{R} \$ 1,23$ e apresenta competitividade restrita. Incentivada, a tarifa pode variar entre $\mathrm{R} \$ 1,19 \mathrm{e}$ $\mathrm{R} \$ 0,67 / \mathrm{m}^{3}$. No caso de resíduos rurais, os valores variam de $\mathrm{R} \$ 1,49$ a $\mathrm{R} \$ 1,30 / \mathrm{m}^{3}$ (EPE, 2014a).

Sob o ponto de vista da competitividade com parte do gás natural no mercado brasileiro, portanto, o biometano pode mostrar competitividade com o GNL importado e, mais dificilmente, com o gás boliviano. Por outro lado, para traçar estratégias para a comercialização de fato do biometano em relação aos usos finais em que ele pode ser competitivo, cabe avaliar os preços de venda praticados do gás natural. A Figura 34 compara os preços de gás natural nos mercados residencial e veicular com os preços dos energéticos concorrentes.

Figura 34. Comparativo de preços entre gás natural residencial, GLP, GNV e gasolina em São Paulo, em fevereiro de 2017.

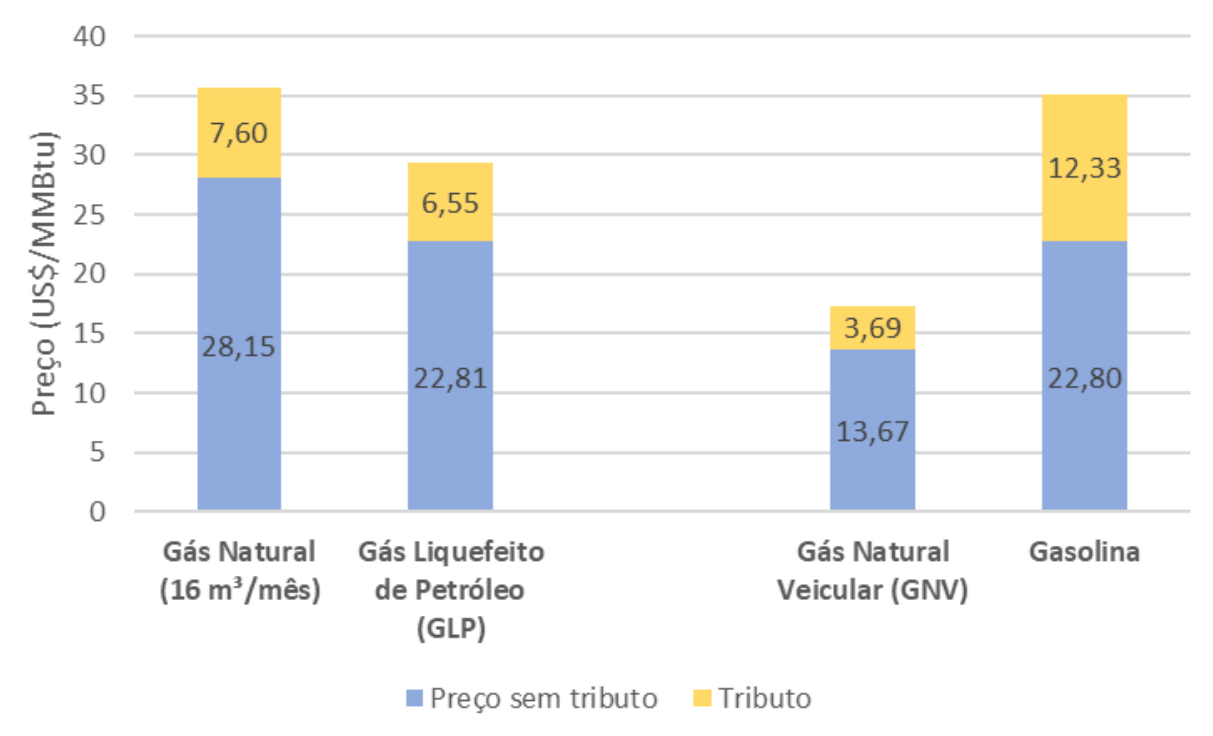

Fonte: o autor a partir de MME (2016).

Fica claro dos preços do gás natural que os preços mais altos estão no setor residencial. No mercado veicular, mesmo o GNV, mais barato que a gasolina e que o gás natural residencial, tem se mantido estagnado, como mostrou a Seção 5.4, e o biometano dificilmente teria mais sucesso em competitividade. O cenário de preços, apresentados apenas para fevereiro de 2017 , tem seguido a mesma característica nos últimos anos (MME, 2016, p. 27). 
Cabe avaliar, em trabalhos futuros, as oportunidades e barreiras do biometano para o mercado residencial, e qual a estrutura de custos, incluindo a distribuição do combustível, para os preços nesse mercado serem, como mostram os dados, cerca de duas vezes maior que os do GNV.

\subsection{Importações/Exportações}

A balança de importações e exportações no setor energético tem forte correlação com a dimensão segurança no abastecimento e a dimensão econômica da política energética. A busca por autossuficiência em energia - sinônimo de independência energética -, ou pela redução da dependência externa, tem sido objetivo de diversos países ao longo do tempo (YERGIN, 2014), inclusive do Brasil (PINTO JR. et al., 2007).

Por outro lado, a obsessão pela autossuficiência é alvo de críticas. Nivola e Carter (2010), ao analisar a situação dos Estados Unidos, atentam para o desperdício que significa a produção local de commodities que podem ser compradas, a menor custo, no mercado externo. Isso representaria uma ineficiência na alocação de recursos, por investir em indústrias fundamentalmente não competitivas em detrimento de outras que poderiam aproveitar os recursos de maneira mais eficiente.

Ao se analisar o cenário brasileiro de importações e exportações de energia, nota-se que há superávit na balança de petróleo bruto, por exemplo, e déficit na produção nacional de produtos de mais alto valor agregado, como nafta e óleo diesel. A Figura 35 mostra as importações líquidas no ano de 2015 no Brasil. 
Figura 35. Importações líquidas ${ }^{16}$ para os principais energéticos no Brasil em 2015, em termos de energia.

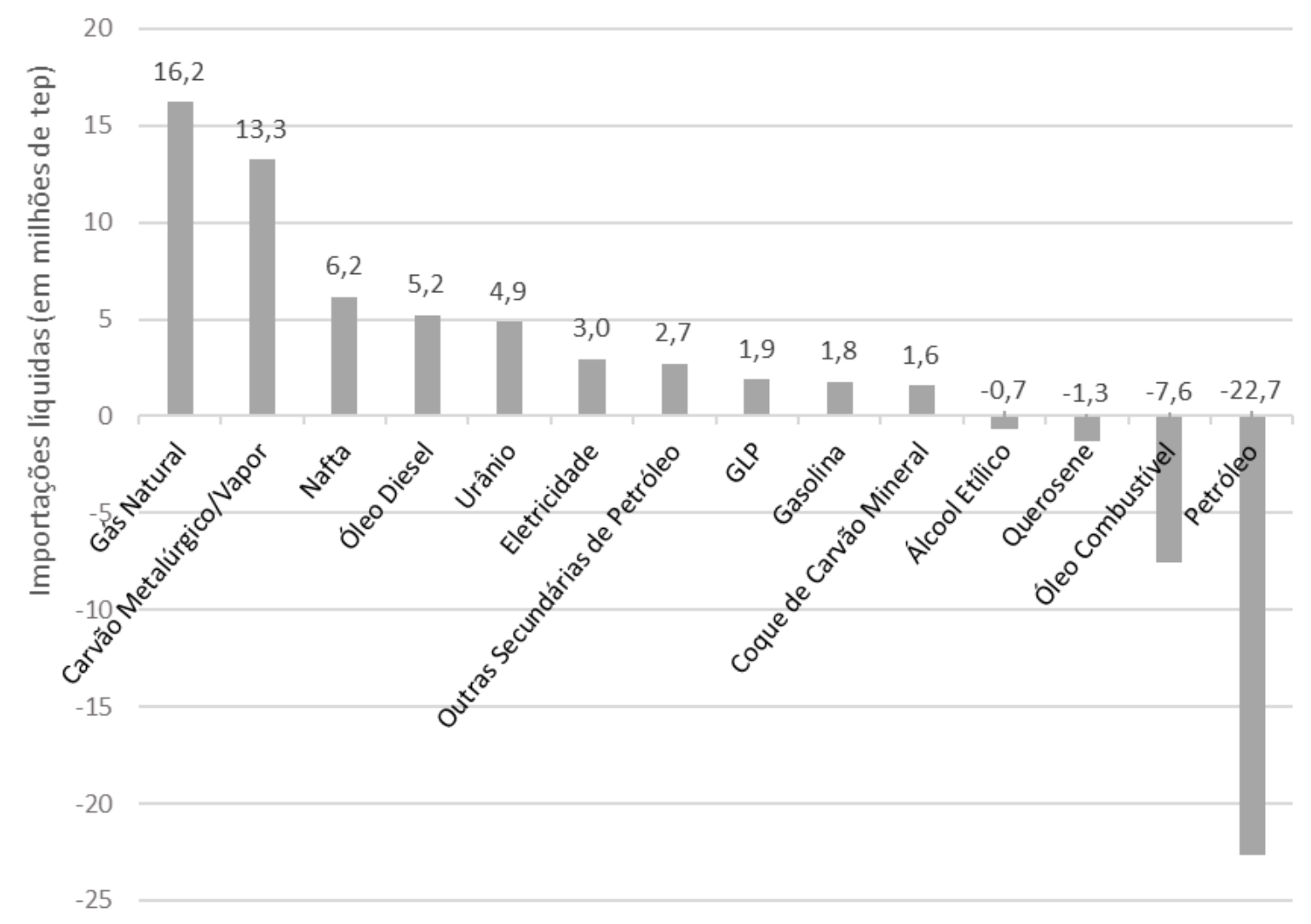

Fonte: elaborado a partir de EPE (2016).

De acordo com a Figura 35, o gás natural foi o energético com maior importação líquida em termos de energia em 2015. No total, foram importados 18,4 bilhões de $\mathrm{m}^{3}$ de gás natural (EPE, 2016a), correspondendo a cerca de $43 \%$ do consumo total.

Em 2016, a importação foi reduzida. De acordo com dados de MME (2016), o volume de gás importado diminuiu para 11,7 bilhões de $\mathrm{m}^{3}$, acompanhando a redução da demanda, que foi menor em cerca de 6 bilhões de $\mathrm{m}^{3}$ na geração de energia elétrica e em cerca de 1 bilhão no setor industrial.

Apesar da redução das importações em 2016, a situação de 2015 não é excepcional. As importações líquidas de gás natural têm se destacado se comparadas com a importação de outros energéticos, como mostra a Figura 36.

16 Importações líquidas corresponde às importações subtraídas das exportações. Portanto, caso o valor seja positivo, há mais importações do que exportações; caso seja negativo, há mais exportações do que importações. 
Figura 36. Importações líquidas de gás natural, óleo diesel, eletricidade, GLP e gasolina, de 2006 a 2015.

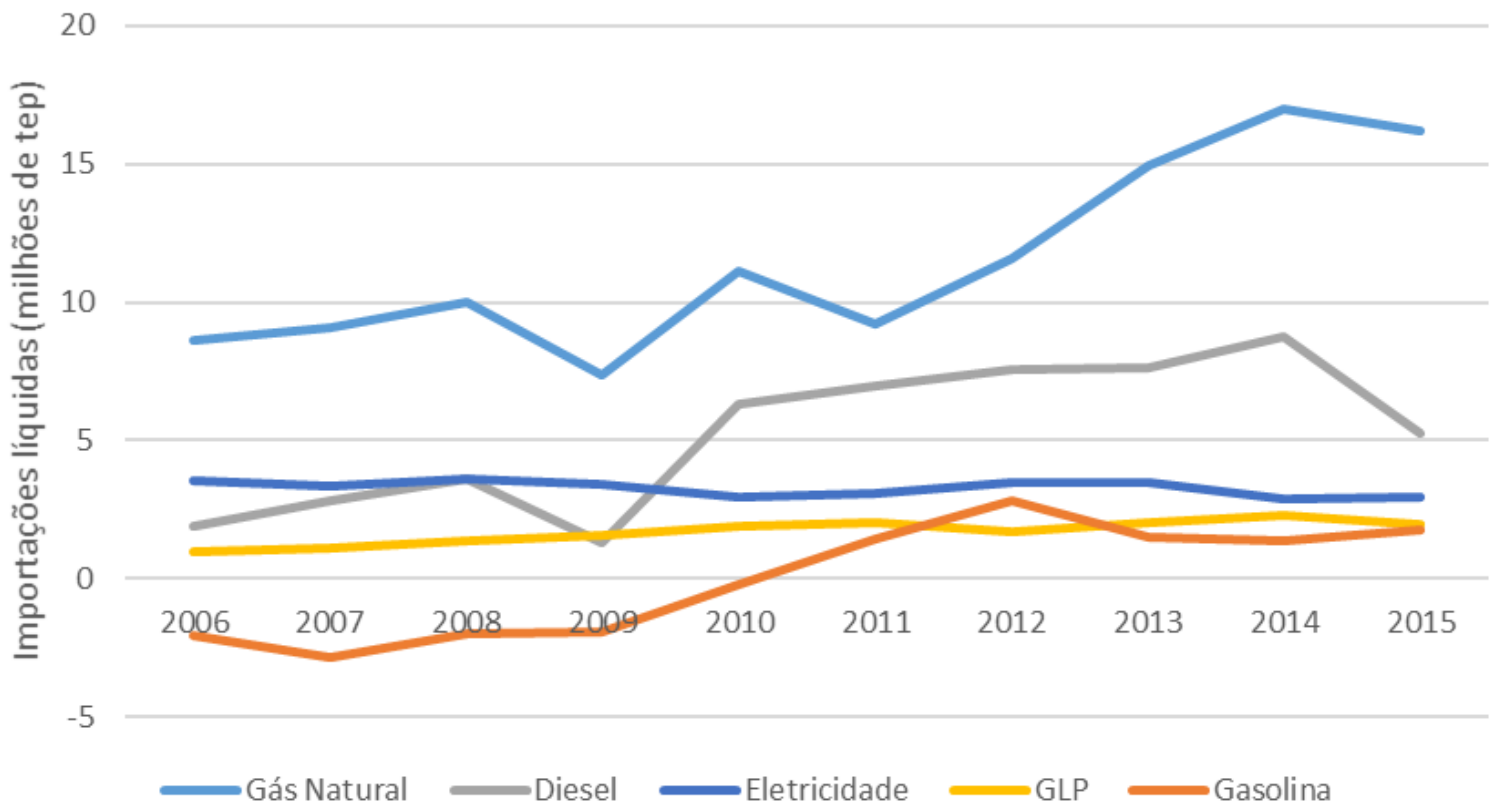

Fonte: elaborado a partir de (EPE, 2016a).

Portanto, constata-se que o gás natural é, certamente, um dos combustíveis com o balanço entre importações e exportações mais desfavorável para o país, em termos de energia. Isso representa uma oportunidade para a produção nacional de biometano, que poderia, gradualmente, substituir parte da importação de gás natural.

Cabe, portanto, avaliar a origem das importações de gás natural no Brasil. Como mostra a Figura 37, o principal parceiro comercial nesse energético é a Bolívia, país do qual a importação é realizada por meio do gasoduto Bolívia-Brasil (Gasbol), que entrou em operação comercial em 1999. 
Figura 37. Importação de gás natural e geração de energia elétrica por gás natural, de 2010 a 2016, no Brasil, em milhões de $\mathrm{m}^{3}$ por dia.

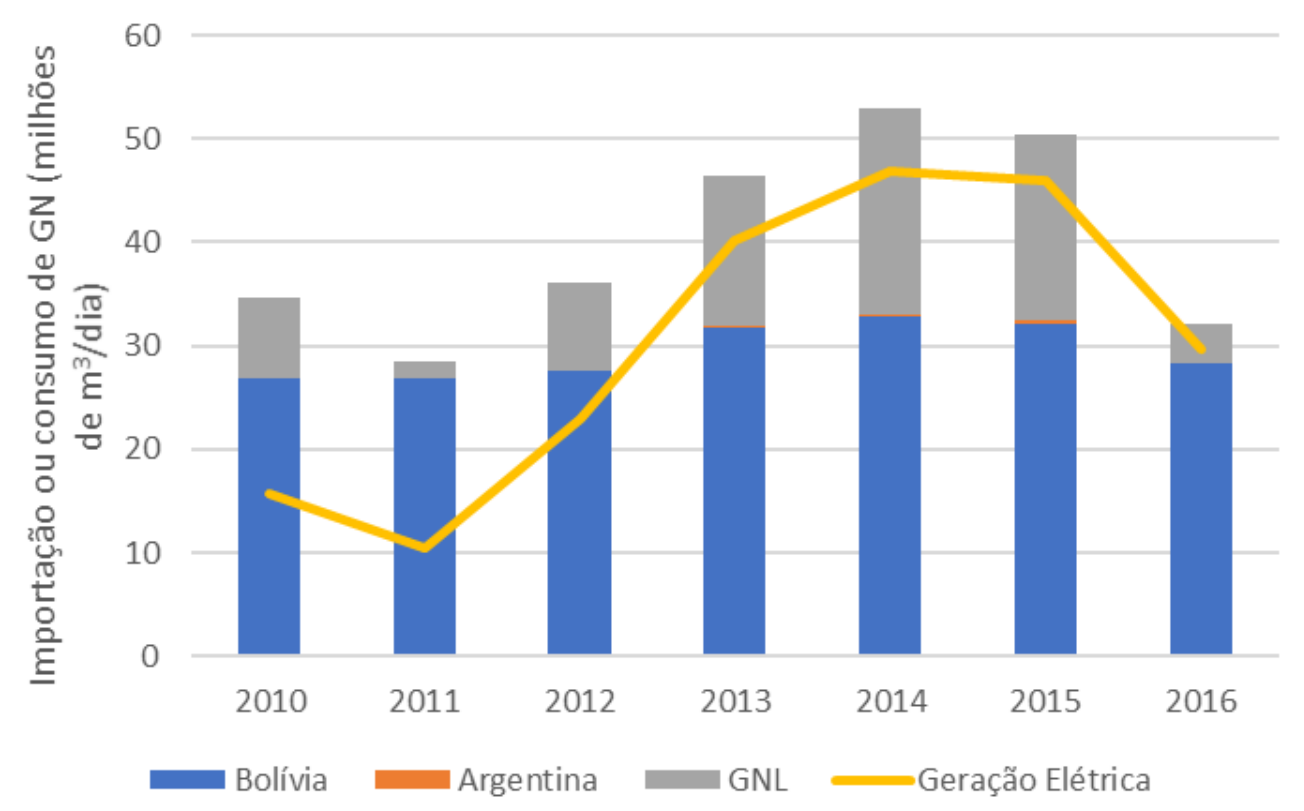

Fonte: elaborado a partir de MME (2016).

A Figura 37 ainda revela que a importação pela regaseificação de GNL - proveniente de diversos países - tende a se relacionar com a demanda de gás natural para a geração de energia elétrica. De fato, segundo Romeiro (2016), a opção flexível do GNL foi escolhida para acomodar o caráter variável e imprevisível da demanda termoelétrica. Por outro lado, a importação da Bolívia se mostra relativamente constante, característica mais adaptada à produção de biogás.

A relação do Brasil com a Bolívia para o gás natural foi avaliada por Barufi, Santos e Ide (2006, p. 183) como um "elemento da segurança energética de longo prazo ao qual o Brasil não deve renunciar", incluindo também a importância da "possibilidade de integração econômica e política das duas nações”, mesmo no contexto da nacionalização das reservas de gás bolivianas e exigência de aumento nos preços do gás exportado ao Brasil. Esse episódio, segundo EPE (2017), fez com que fossem tomadas medidas de infraestrutura para garantir a segurança do abastecimento, como a implantação de terminais de regaseificação de GNL e desenvolvimento nacional de campos de gás.

Atualmente, o contexto é de aproximação do vencimento do contrato de fornecimento de gás entre os dois países, no ano de 2019. Segundo a EPE (2017), a Bolívia pode ter dificuldades de manter os níveis de exportação atuais, sendo considerado provável que ocorra renovação do 
contrato, mas com volumes menores que os negociados atualmente. São citados o aumento da produção doméstica (onshore e do pré-sal) e a importação de GNL alinhada ao despacho termoelétrico como as principais estratégias para atender a essa futura demanda.

Portanto, existe a oportunidade para o biometano se desenvolver como alternativa para substituir parte das importações e contribuir com a segurança do suprimento de gás.

Por outro lado, uma análise mais aprofundada da questão envolvendo a balança comercial no setor de biogás e biometano pode identificar a presença de componentes importados nas tecnologias envolvidas, por exemplo, no processo de tratamento do biogás, e analisar seu impacto. Segundo Leme e Seabra (2017), faltam no Brasil fornecedores de tecnologia com experiência no setor, e os custos de importação e a taxa de câmbio podem influenciar significativamente os custos do biometano; eles sugerem o incentivo ao desenvolvimento de fornecedores nacionais - que estaria de acordo com o objetivo de minimizar importações. Por outro lado, também sugerem incentivo à nacionalização de equipamentos e descontos em impostos de importação para acelerar a curva de aprendizado de projetos de produção de biometano a partir da vinhaça.

\subsection{Infraestrutura energética}

A infraestrutura é mais um aspecto que envolve a dimensão segurança no abastecimento e a dimensão econômica da energia. Uma infraestrutura confiável garante a disponibilidade da energia e a possibilidade do atendimento da demanda do sistema de forma a minimizar os custos e com os recursos mais adequados. A infraestrutura de transporte de energia é importante para tirar partido das complementaridades entre recursos naturais e mercados em um processo de integração regional (PINTO JR. et al., 2007).

O desenvolvimento de uma infraestrutura de redes de transporte de energia, integrada, interconectada e confiável, tem diversos benefícios. Entre eles, a melhoria da eficiência da operação do sistema pelo acesso aos recursos mais eficientes, maior segurança do suprimento por permitir acesso à geração firme, e o aumento da capacidade de acomodar geração renovável intermitente, aproveitando a diversidade regional dos recursos (EUROPEAN UNION, 2011; STRBAC et al., 2016).

A indústria de energia elétrica e a do gás natural - ao qual o biometano pode substituir são consideradas indústrias de rede, e se caracterizam pela necessidade de infraestrutura para conectar oferta e demanda. Essas indústrias têm algumas características básicas, como: 
necessidade de equilíbrio temporal entre oferta e demanda devido às dificuldades de estocagem; importantes economias de escopo e escala, principalmente no transporte e distribuição; e altos investimentos em ativos fixos e específicos, implicando pouca flexibilidade e "custos perdidos" (do inglês "sunk costs") (DIAS; RODRIGUES, 1997; EPE, 2014d).

Essas indústrias de rede são insumos básicos para outras atividades, sendo essenciais para o desenvolvimento econômico; são consideradas indústrias de infraestrutura. Acende Brasil (2015), afirma para o caso do setor elétrico que a transmissão de energia pode ser considerada a "infraestrutura da infraestrutura". Isso porque a transmissão integra o setor, permitindo a operação como um sistema coeso e de forma otimizada, explorando e integrando os recursos e as vantagens das diferentes fontes e tecnologias, e aumentando a confiabilidade do sistema.

O sistema de transmissão de energia elétrica brasileiro, o Sistema Interligado Nacional (SIN), tinha em 2015 mais de 129 mil km de extensão em linhas de tensão igual ou maior que 230 kV. A evolução dessa parte da infraestrutura do SIN, de 2011 a 2015, está na Tabela 12.

Tabela 12 - Extensão, em km, das linhas de transmissão do Sistema Interligado Nacional (SIN) com tensão maior ou igual a $230 \mathrm{kV}$

\begin{tabular}{|c|c|c|c|c|c|c|}
\hline Tensão & $\mathbf{2 0 1 1}$ & $\mathbf{2 0 1 2}$ & $\mathbf{2 0 1 3}$ & $\mathbf{2 0 1 4}$ & $\mathbf{2 0 1 5}$ & $\begin{array}{c}\text { Var \% } \\
\mathbf{1 5 / 1 4}\end{array}$ \\
\hline $\mathbf{2 3 0 k V}$ & $45.708,7$ & $47.893,5$ & $49.969,0$ & $52.449,8$ & 53910,3 & 2,78 \\
\hline $\mathbf{3 4 5 k} \mathbf{V}$ & $10.061,9$ & $10.223,9$ & $10.272,3$ & $10.303,2$ & $10.303,2$ & - \\
\hline $\mathbf{4 4 0 k} \mathbf{V}$ & $6.680,7$ & $6.728,2$ & $6.728,2$ & $6.728,2$ & $6.733,3$ & 0,08 \\
\hline $\mathbf{5 0 0 k} \mathbf{V}$ & $35.003,4$ & $35.726,2$ & $39.123,1$ & $40.659,4$ & $42.622,1$ & 4,83 \\
\hline $\mathbf{6 0 0 k} \mathbf{V}$ & $3.224,0$ & $3.224,0$ & $7.992,0$ & $12.816,0$ & $12.816,0$ & - \\
\hline $\mathbf{7 5 0 k V}$ & $2.683,0$ & $2.683,0$ & $2.683,0$ & $2.683,0$ & $2.683,0$ & - \\
\hline Total SIN & $103.361,7$ & $106.478,8$ & $116.767,7$ & $125.639,6$ & $129.067,9$ & 2,73 \\
\hline
\end{tabular}

Fonte: ONS (2016).

Nota-se o crescimento da extensão das linhas de transmissão do SIN, especialmente nas de 230, 500 e $600 \mathrm{kV}$, chegando a mais de $129 \mathrm{mil} \mathrm{km} \mathrm{em} \mathrm{2015.} \mathrm{De} \mathrm{fato,} \mathrm{a} \mathrm{expansão} \mathrm{das} \mathrm{linhas}$ é permanente. Em 2003, eram cerca de 77 mil km de rede, e em 2008, 89 mil (ACENDE BRASIL, 2015). A distribuição dessa infraestrutura no território nacional, incluindo linhas de 130 kV, está esquematizada na Figura 38. 
Figura 38. Esquema da infraestrutura de transmissão de energia elétrica no Sistema Interligado Nacional (SIN).

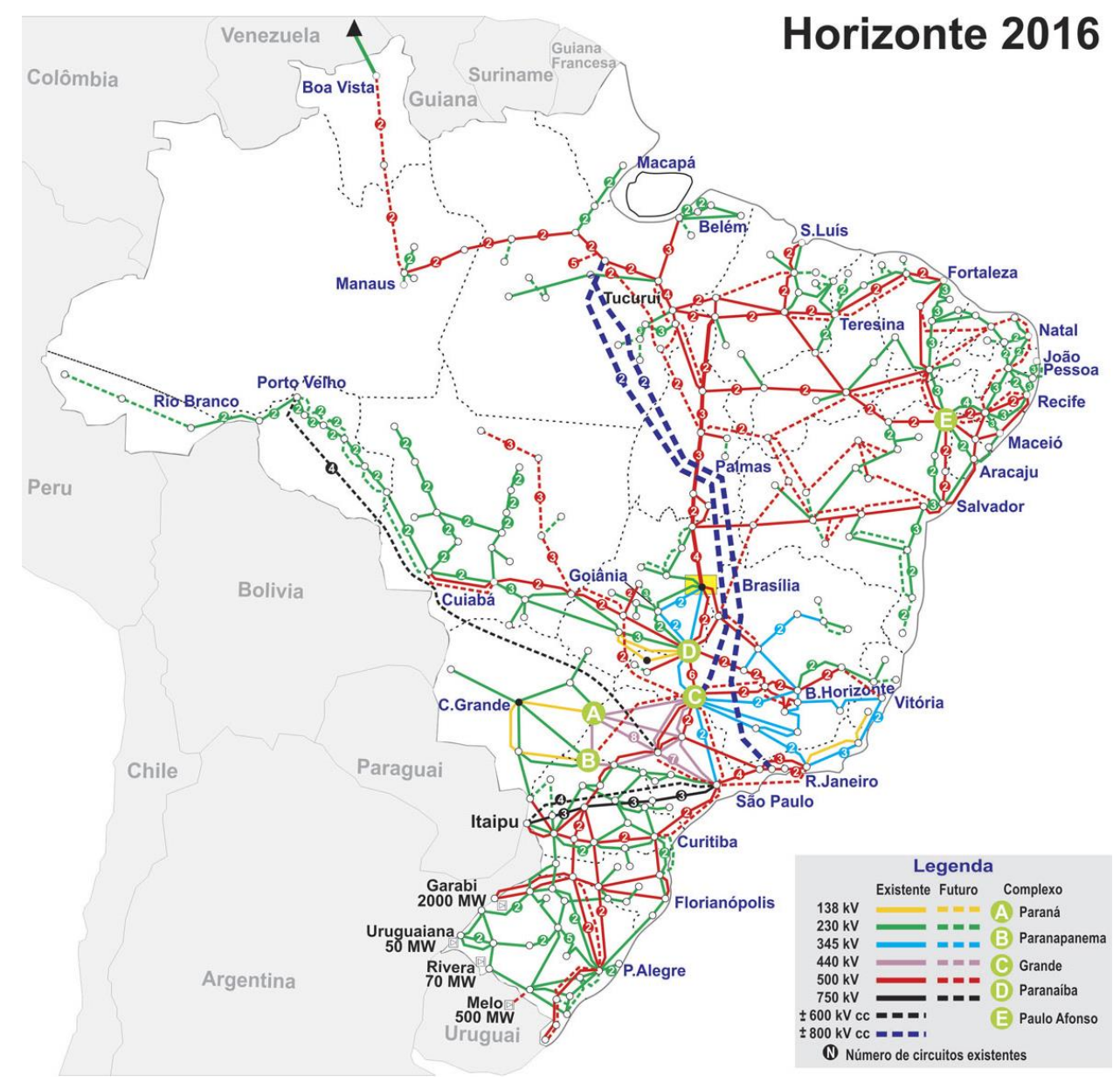

Fonte: ONS (2016).

Nota-se, da Figura 38, que a infraestrutura de transmissão do SIN é concentrada principalmente nas regiões Sul e Sudeste e, em menor grau, nas regiões Nordeste e CentroOeste. Segundo Acende Brasil (2015), o sistema brasileiro é um dos mais integrados do mundo, sendo que a característica de predominância do aproveitamento de recursos hidroelétricos favoreceu a construção da rede de transmissão que interliga todas as regiões do país. A operação coordenada pelo Operador Nacional do Sistema Elétrico (ONS) e a possibilidade de troca de energia entre regiões com regimes hidrológicos diferentes é elemento importante da garantia do suprimento (ANEEL, 2008).

A infraestrutura de transporte de gás natural, por outro lado, é concentrada no litoral do país e no gasoduto Bolívia-Brasil (Gasbol), como mostra a Figura 39. 
Figura 39. Diagrama esquemático da infraestrutura de gasodutos de transporte no Brasil

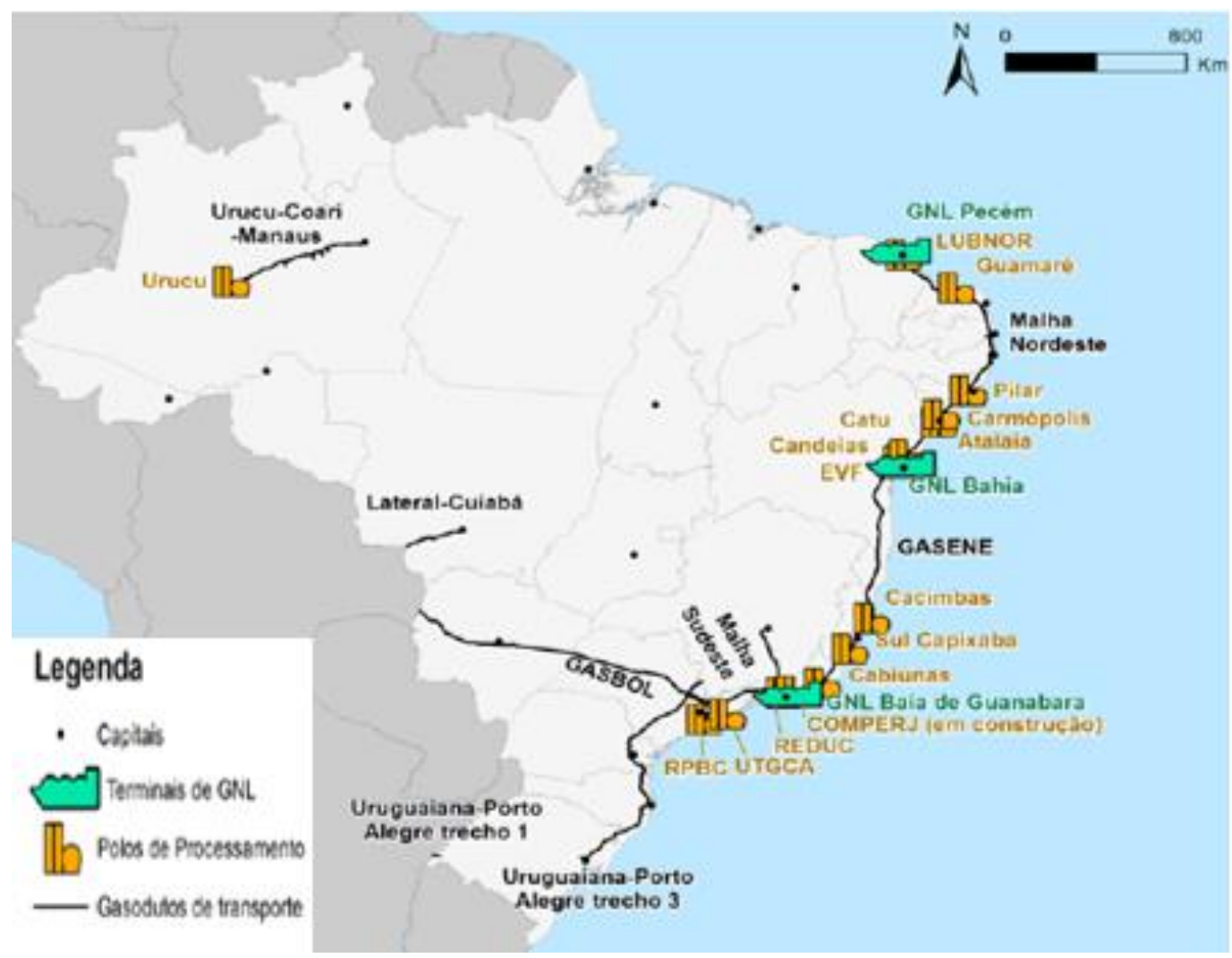

Fonte: adaptado de EPE (2015a).

A infraestrutura de distribuição se desenvolveu ao longo dos principais eixos de transporte de gás natural e em busca dos principais mercados para o gás nacional e importado, principalmente, da Bolívia. A Figura 40 mostra a infraestrutura de gás, incluindo gasodutos de distribuição, em parte do território nacional, que inclui as capitais das regiões Sul e Sudeste. Na Figura 41, nota-se que a malha de transporte se desenvolveu de forma discreta em relação à evolução da malha de distribuição de gás, desde 1999, ano do início da operação do Gasbol sendo considerada a sua interligação com a malha Sudeste do sistema Petrobrás o "marco zero" do desenvolvimento de gasodutos no Brasil (EPE, 2014d). 
Figura 40. Infraestrutura de gás natural, incluindo gasodutos de distribuição, em área abrangendo as capitais das regiões Sul e Sudeste do Brasil

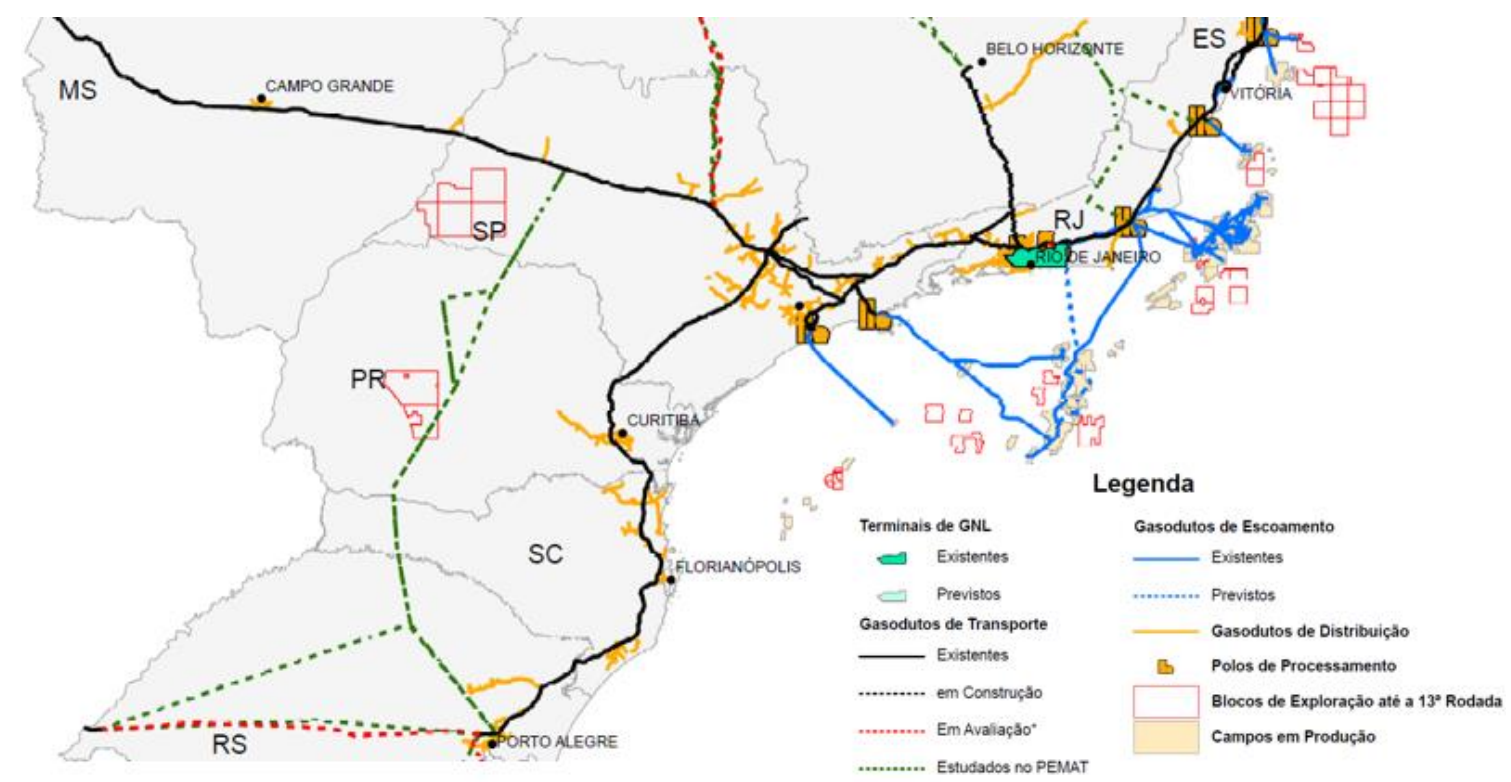

Fonte: EPE (2016c).

Figura 41. Evolução das malhas de transporte e distribuição de gás natural no Brasil, de 1999 a 2016

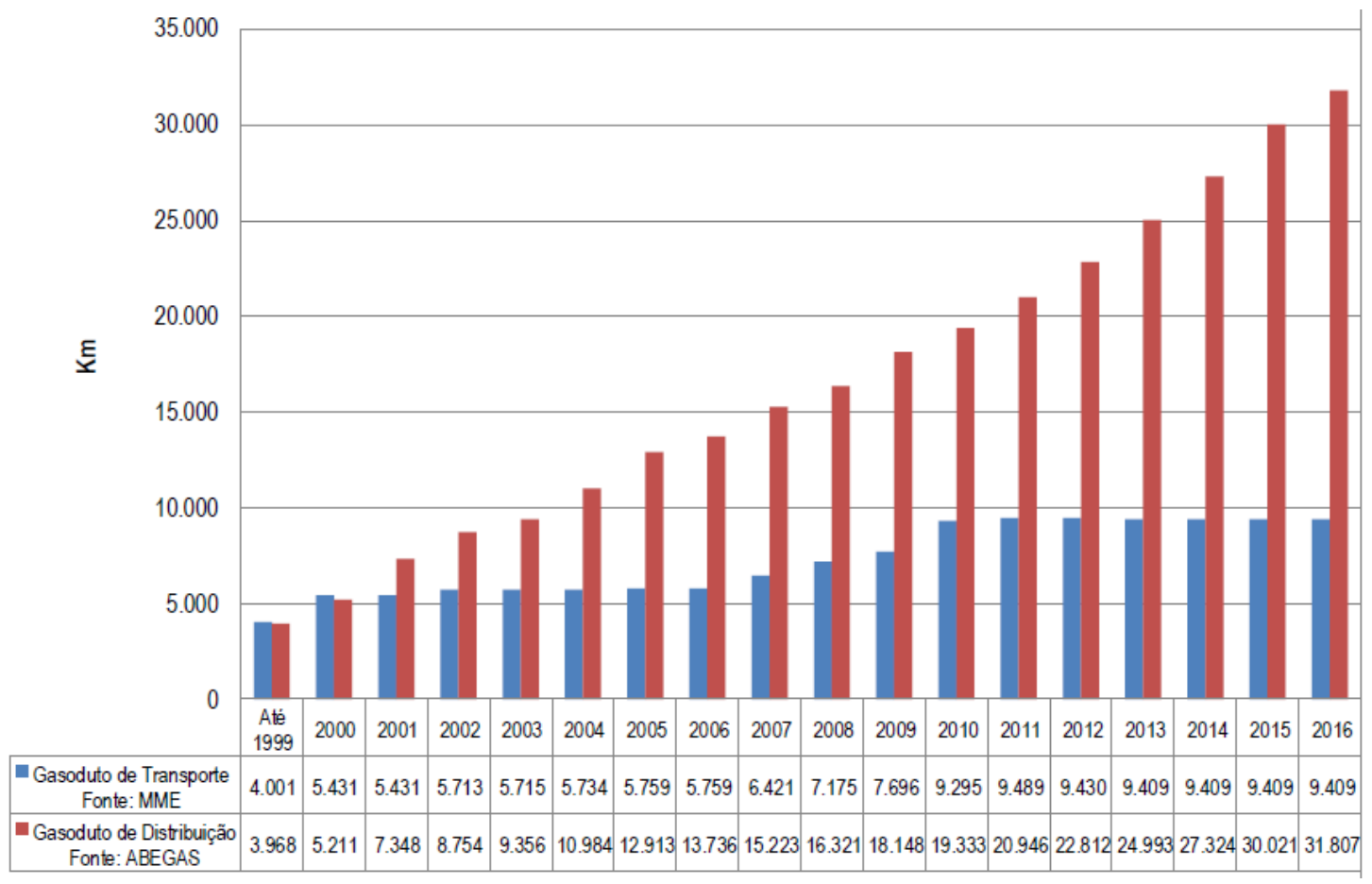

Fonte: (MME, 2016).

Identifica-se, portanto, déficit de infraestrutura de gás natural, se houver intenção de expandir a produção e o consumo, principalmente no interior do país. A comparação da malha 
de transporte de gás natural com a de outros países também aponta para a limitação da infraestrutura nacional, como mostra a Figura 42.

Figura 42. Comparação da malha de gasodutos de transporte entre diversos países

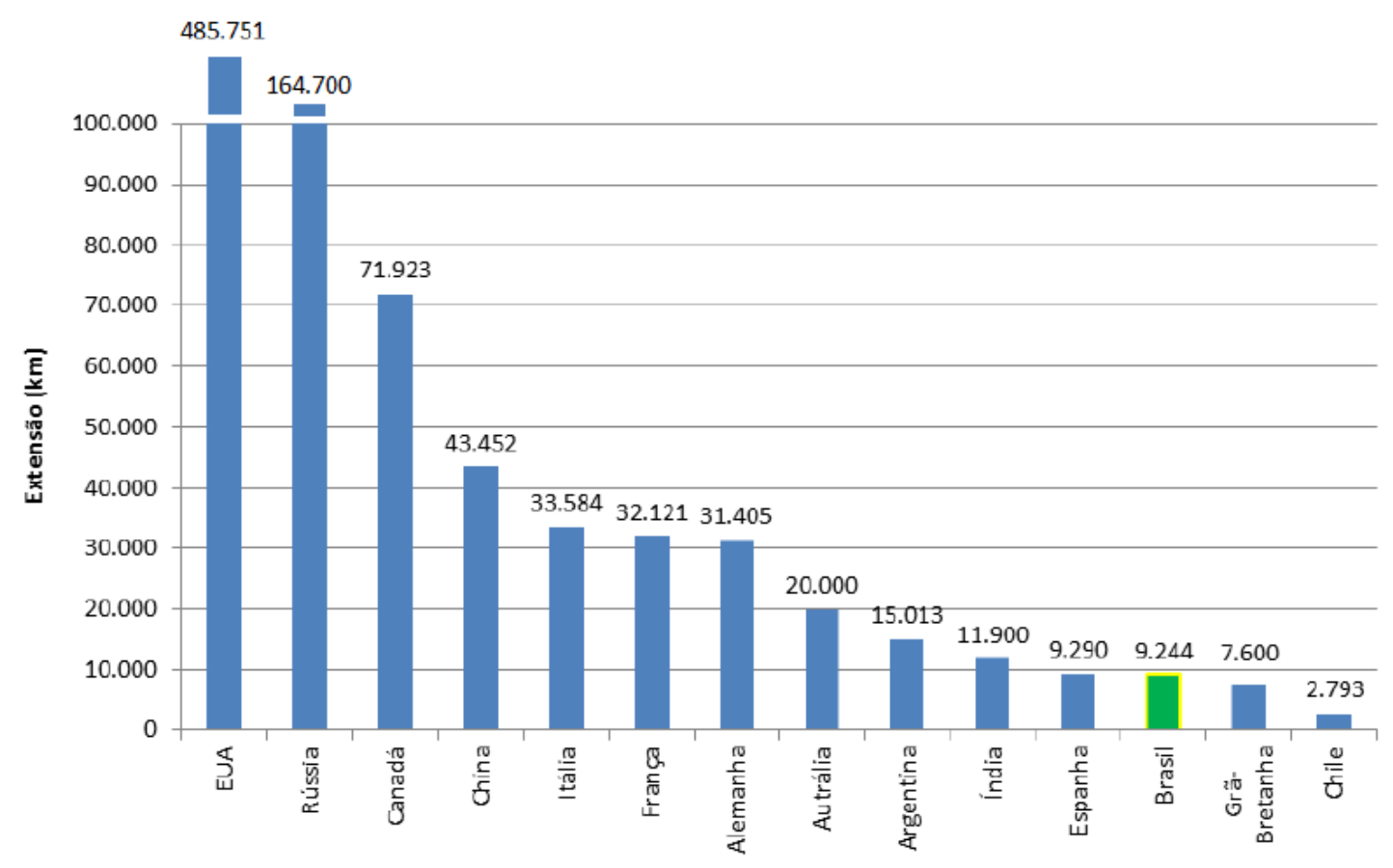

Fonte: (EPE, 2014d).

Avaliando o caso sueco, Larsson, Gronkvist e Alvfors (2016) notaram, no entanto, que a existência de rede de gás natural não foi um pré-requisito para a produção e utilização de biometano no setor de transportes do país pois, mesmo na ausência de infraestrutura, essa alternativa se desenvolveu. A presença da rede, no entanto, pode ser positiva, mas também há risco de competição nos custos. Sanches-Pereira et al. (2015) afirmam que o gás natural é um regulador dos preços, responsável pela atratividade do gás veicular (mistura de biometano e gás natural) na Suécia.

Por outro lado, a rede de distribuição de GLP no Brasil é consolidada, sendo um de seus principais trunfos, chegando a mais de 53 milhões de residências (MOURA, 2012). A distribuição do biometano em cilindros e transportado por caminhões, por exemplo, pode se aproveitar dessa rede e superar a falta de infraestrutura por gasodutos. $\mathrm{O}$ transporte em cilindros, no entanto, requer pressões maiores - e maior gasto energético - em relação à injeção na rede de gás natural (LARSSON; GRONKVIST; ALVFORS, 2016). 
Sabe-se que o potencial energético do biogás, dependendo da fonte, pode estar concentrado em grandes aglomerados urbanos, como resíduos sólidos urbanos, estações de tratamento de esgoto, e parte do potencial da vinhaça e industrial. Por outro lado, o potencial associado aos resíduos agrícolas e da pecuária, por exemplo, está distribuído pelo interior. A capacidade da infraestrutura de energia elétrica e de gás natural para atender ao potencial de produção de biogás deve quantificar e localizar o potencial e confrontá-lo com a infraestrutura disponível.

Deve-se avaliar também que a disponibilidade do potencial energético do biogás pode contribuir com a interiorização da infraestrutura, principalmente no caso do gás natural, que é menos desenvolvida. O biometano pode funcionar como indutor de um mercado, iniciar a construção de redes locais, e estimular o desenvolvimento da infraestrutura.

\subsection{Aspectos ambientais}

A discussão da questão ambiental no setor energético tem como principal expoente atualmente as emissões de gases de efeito estufa (GEE) e as mudanças climáticas. Portanto, um dos principais objetivos da inserção de energias renováveis como o biogás é a substituição de fontes fósseis e redução dessas emissões. A Tabela 13 mostra a diferença de emissões de GEE entre fontes renováveis e fósseis por unidade de energia gerada no Brasil.

Tabela 13 - Fatores de emissão de GEE por tecnologia de geração no Brasil

\begin{tabular}{|l|c|}
\hline Tecnologia de geração & $\begin{array}{c}\text { Fator de emissão } \\
\text { (kgCO } \mathbf{2} \mathbf{e q} / \mathbf{M W h})\end{array}$ \\
\hline Hidroeletricidade & 86 \\
\hline Eólica & 16 \\
\hline Nuclear & 14 \\
\hline Termoelétrica - carvão mineral & 1.144 \\
\hline Termoelétrica - gás natural & 518 \\
\hline Termoelétrica - óleo combustível & 781 \\
\hline Termoelétrica - óleo diesel & 829 \\
\hline
\end{tabular}

Fonte: adaptado de (MIRANDA, 2012).

No setor elétrico, como já avaliado na Seção 2.4, há uma diversidade de fontes renováveis com grande potencial no Brasil, com destaque para as fontes hidráulica e eólica, que apresentam 
fatores de emissão baixos comparados às fontes fósseis. Portanto, a redução de emissões depende da fonte sendo substituída pelo biogás.

Outra questão da utilização do biogás no setor elétrico são as emissões de poluentes, especialmente $\mathrm{SO}_{\mathrm{X}}$ e $\mathrm{NO}_{\mathrm{X}}$, causadores de poluição local e regional e de chuva ácida (GOLDEMBERG; LUCON, 2012).

Os óxidos de enxofre são provenientes da oxidação de compostos de enxofre, como o $\mathrm{H}_{2} \mathrm{~S}$, presentes na composição do biogás. Portanto, as emissões de $\mathrm{SO}_{\mathrm{X}}$ são consequência basicamente, da concentração de $\mathrm{H}_{2} \mathrm{~S}$ no biogás; assim, um processo de limpeza adequado, removendo $\mathrm{H}_{2} \mathrm{~S}$, pode reduzir as emissões de $\mathrm{SO}_{\mathrm{X}}$, associado à maior proteção e durabilidade dos equipamentos.

Os óxidos de nitrogênio são gerados na combustão pela presença de $\mathrm{N}_{2}$ no ar e tem pouca relação com a composição do biogás. As emissões de $\mathrm{NOx}$ são produzidas por todos os combustíveis, e dependem do tipo de equipamento usado para geração, como avaliado na Seção 3 , podendo ser reduzidas com o uso de microturbinas.

Segundo CETESB (2006), podem ser utilizadas tecnologias de controle e redução de emissões, como lavadores de gases e redução catalítica seletiva, para o $\mathrm{SO}_{\mathrm{X}}$ e o $\mathrm{NO}$, respectivamente.

Portanto, as emissões de $\mathrm{SO}_{\mathrm{x}}$ e $\mathrm{NO}_{\mathrm{x}}$ podem ser vistas como uma desvantagem da geração elétrica com biogás, se comparada a outras renováveis que não realizam combustão.

Por estes fatores, torna-se importante compreender o papel que o biogás pode desempenhar na geração elétrica e que fontes pode substituir. A avaliação do benefício ambiental dessa fonte é dependente dessa questão, e nesse ponto suas características de geração firme e flexível são decisivas.

Ainda, o aproveitamento energético do biogás na geração de eletricidade é maior se é utilizado um sistema de cogeração, ou seja, com a utilização do calor residual. No entanto, pode não haver demanda ou viabilidade para o uso da energia térmica. Como a eficiência elétrica pode variar de $18 \%$ a $47 \%$ e a eficiência térmica pode chegar a 55\% (PROBIOGÁS, 2015a), o não-aproveitamento do calor pode significar grande desperdício. A falta de utilização dessa energia é um dos pontos que torna interessante a produção de biometano, que pode, então, levar a energia para ser utilizada em locais com maior eficiência na utilização da energia. 
No entanto, a produção de biometano tem suas próprias questões sensíveis. As perdas de metano podem ter consequências negativas para o balanço de emissões do sistema, devido ao seu potencial de aquecimento global, caso seja emitido diretamente à atmosfera. Com o objetivo de evitar essa emissão, há a necessidade de tratamento do gás residual, que pode ser realizado por diversas técnicas (DWA, 2011). A perda de metano também diminui o aproveitamento da energia disponível do biogás.

Ainda, o processo de limpeza e enriquecimento, ou upgrading, consome energia. Segundo Probiogás (2015), as tecnologias de upgrading tem consumos de eletricidade distintos entre si, mas variam de cerca de 0,2 a $0,3 \mathrm{kWh}_{\text {el }}$ por $\mathrm{m}^{3}$ de biogás bruto, por exemplo, para a técnica de lavagem com água; os valores estão de acordo com DWA (2011), que avalia em aproximadamente $0,25 \mathrm{kWh} / 1 \mathrm{~m}^{3}$, e com o levantamento de Sun et al. (2015), que apresenta dados de consumo de eletricidade em cerca de $0,45 \mathrm{kWh} / \mathrm{m} \mathrm{m}^{3}$ de biometano produzido ${ }^{17}$. Supondo que a energia elétrica para a produção do biometano fosse gerada com o próprio biogás em um gerador com eficiência elétrica de $30 \%$, e adotando o consumo de eletricidade no valor de $0,3 \mathrm{kWh} \mathrm{e}_{\mathrm{e}} / \mathrm{m}^{3}$ de biogás, o consumo em energia no upgrading chega a $1 \mathrm{kWh} / \mathrm{m}^{3}$ de biogás, correspondendo a cerca de $17 \%$ do conteúdo energético do biogás ${ }^{18}$. Ainda, técnicas como a absorção química apresentam demanda por energia térmica que, caso suprida por fontes fósseis, pode aumentar as emissões do processo.

O sistema alemão de incentivos, como foi mostrado na Seção 4.4.1, buscou eficiência no aproveitamento da energia e garantir o desempenho ambiental dos sistemas. Entre os requisitos para o recebimento de bônus pelo processamento do gás, exigia-se cumprimento do máximo de emissões de metano para a atmosfera, do consumo máximo de eletricidade e que o suprimento da energia térmica do sistema de produção e processamento do gás fosse proveniente de fontes renováveis (ver Tabela 9). A adoção de regras para se tornarem elegíveis a incentivos, nos moldes das que estiveram em vigor na Alemanha, podem ser uma maneira de assegurar o objetivo de redução de emissões com a produção e uso do biometano.

Por fim, como a regulação da concentração de $\mathrm{H}_{2} \mathrm{~S}$ no biometano é restrita a $10 \mathrm{mg} / \mathrm{Nm}^{3}$ (ANP, 2015), as emissões de $\mathrm{SO}_{\mathrm{X}}$ na queima do combustível tendem a ser reduzidas em relação

\footnotetext{
${ }^{17}$ Considerando perda de metano de $2 \%$ e concentração de metano no biogás de $60 \%$, o consumo de 0,2 kWh por $\mathrm{m}^{3}$ de biogás bruto corresponde a $0,34 \mathrm{kWh} / \mathrm{m}^{3}$ de biometano produzido, e o de $0,3 \mathrm{kWh}$ por $\mathrm{m}^{3}$ de biogás bruto a $0,51 \mathrm{kWh} / \mathrm{m}^{3}$ de biometano.

${ }^{18}$ Considerando o poder calorífico do metano em $9,97 \mathrm{kWh} / \mathrm{m}^{3}$ (FNR, 2013) e o biogás com $60 \%$ de metano, ou seja, com poder calorífico de cerca de $6 \mathrm{kWh} / \mathrm{m}^{3}$ de biogás bruto. Portanto, o consumo de $1 \mathrm{kWh}$ corresponde a $16,67 \%$ dos 6 kWh de biogás bruto.
} 
à queima do biogás em unidades de cogeração, em que o limite mínimo de concentração de $\mathrm{H}_{2} \mathrm{~S}$ pode ser de $100 \mathrm{mg} / \mathrm{Nm}^{3}$ a até $500 \mathrm{mg} / \mathrm{Nm}^{3}$ (DEUBLEIN; STEINHAUSER, 2008), ou seja, cerca de 10 a 50 vezes maior que no biometano. Considerando que o metro cúbico de biogás tem cerca de $60 \%$ do conteúdo energético do metro cúbico do biometano, a quantidade de $\mathrm{H}_{2} \mathrm{~S}$ por energia disponível no biogás seria de 16 a 84 vezes maior que no biometano. Portanto, a imposição, pela regulação, da concentração máxima de $\mathrm{H}_{2} \mathrm{~S}$ no biometano faz com que a utilização deste combustível seja preferível em relação à do biogás, neste aspecto. 


\section{UTILIZAÇÃO DO BIOGÁS NO BRASIL}

\subsection{Políticas, propostas e experiência brasileira}

Neste capítulo serão mostradas iniciativas atuais relacionadas ao biogás, que marcam o estágio atual e indicam o desenvolvimento desse setor no Brasil. A lista não é exaustiva das numerosas medidas que poderiam ser incluídas, mas tem como objetivo apresentar avanços, como programas, projetos, e incentivos que têm sido efetivados. Como foco desta análise, serão consideradas as medidas focadas no aproveitamento energético do biogás, mas inicialmente será apresentado o contexto de medidas que podem estimular o crescimento do setor e o aumento da oferta de biogás.

No ano de 2010 foi aprovada a Política Nacional de Resíduos Sólidos (PNRS). Segundo Veiga (2016, p. 17), a PNRS é "um marco legal que regula, inserida em uma hierarquia da gestão de resíduos, a redução da necessidade de disposição final, baseada em revalorização energética dos resíduos como uma de suas possíveis estratégias". Previa-se, como instrumentos da PNRS, a pesquisa científica e tecnológica e incentivos fiscais, financeiros e de crédito.

A PNRS tornou-se, portanto, uma oportunidade para aumentar a recuperação e o aproveitamento do biogás; no entanto, o não cumprimento, por exemplo, de prazos para apresentação de planos em diferentes esferas de governo e o cenário real do gerenciamento de resíduos sólidos urbanos no país dificultam uma evolução para o estágio de países como Alemanha, Suécia e Reino Unido (VEIGA, 2016).

Baseado no Plano Nacional de Saneamento Básico (PLANSAB), de 2013, acredita-se que haverá crescimento do consumo energético no tratamento de esgoto. É previsto o aumento dos $39,7 \%$ adequadamente coletados e tratados em 2013 para $92 \%$ de coleta, dos quais $93 \%$ deverão ser tratados até 2033 (VALENTE, 2015). Assim, o aproveitamento energético do biogás pode se tornar mais relevante no setor como forma de tratamento e de atender à própria demanda energética.

Em 2016, foram colocadas em consulta pública as diretrizes do programa RenovaBio, com objetivo declarado de "expandir a participação de biocombustíveis no Brasil" (BRASIL, 2016c). O fato de o biogás ser citado no plano, e a ABiogás e a Associação Brasileira de Biogás e Metano (ABBM) terem participado dos encontros para elaboração das propostas, como destacado nos documentos enviados para consulta, indica que alguns dos interesses do setor podem estar contemplados nesse programa. 
O RenovaBio está de acordo com o compromisso do Brasil na COP 21, que inclui, entre outros objetivos (EPE, 2016b), "aumentar a participação de bioenergia sustentável na matriz energética para aproximadamente $18 \%$ até 2030, expandindo o consumo de biocombustíveis", e "alcançar uma participação estimada de $45 \%$ de energias renováveis na composição da matriz energética em 2030".

Ainda, Mariani et al. (2014) e Abiogás (2015) listam outras iniciativas na área de biogás no Brasil, incluindo atividades de Pesquisa e Desenvolvimento (P\&D), planos e programas do Governo Federal, e fontes de financiamento. Medidas estaduais, especialmente ligadas à suspensão ou diferenciação de impostos como o ICMS, também são listadas em ABiogás (2015).

Dado que os elementos apresentados podem contribuir com o aumento da oferta do biogás e estimular o setor, em seguida serão avaliadas iniciativas focadas na sua utilização. Elas estarão divididas entre as relacionadas ao biogás para energia elétrica, na Seção 6.1.1, e para o biometano, Seção 6.1.2.

\subsubsection{Regulação e incentivos para geração de energia elétrica}

Na Resolução Normativa (RN) da ANEEL no 271 de 2007, alterando a nº 77 de 2004, foi assegurado a empreendimentos de geração de energia elétrica a partir do biogás o direito a 100\% de redução nas tarifas de uso dos sistemas elétricos de transmissão (TUST) e distribuição (TUSD). As condições são: que utilize no mínimo 50\% de biomassa de resíduos sólidos urbanos ou gás de aterro sanitário, de biodigestores de resíduos vegetais ou animais, ou de lodos de estações de tratamento de esgoto; e que a potência injetada nos sistemas de transmissão ou distribuição seja de, no máximo, $30.000 \mathrm{~kW}$. Outros empreendimentos de mesma potência, como de pequenas centrais hidrelétricas, de fonte solar, eólica, ou biomassa, tem direito a 50\% de redução nas tarifas (ANEEL, 2007).

No setor elétrico, há diversos mecanismos para a comercialização da energia gerada pelo biogás. Uma das formas é o enquadramento na regulação de geração distribuída, estabelecida pela RN da ANEEL no 482 de 2012, e alterada pela RN no 687 de 2015, nos casos de micro e minigeração. Foi permitido o abatimento do consumo da unidade geradora e possibilitado o acúmulo de crédito para consumo futuro, em prazo de até 60 meses, e para transferência para outra unidade consumidora de mesma titularidade na mesma área de concessão, chamado de “autoconsumo remoto" (ANEEL, 2015). Segundo Bley Jr. (2015), criticando a então vigente 
$\mathrm{RN} \mathrm{n}^{\circ}$ 482, a energia elétrica com biogás “sempre” gera excedentes maiores que o consumo; portanto, o estabelecimento dos créditos pode contribuir para viabilizar os projetos de menor porte, mas ainda não se iguala à condição, por exemplo, de uma tarifa feed-in, que remunera diretamente a energia gerada - como estabelecido pela EEG alemã e em diversos países europeus.

Para a geração distribuída, se enquadram a microgeração, para unidades geradoras de potência menor ou igual a $75 \mathrm{~kW}$, e a minigeração, para potências superiores a $75 \mathrm{~kW}$ e até o limite de $5 \mathrm{MW}$, no caso do biogás. Plantas maiores que $5 \mathrm{MW}$ não são autorizadas no âmbito da geração distribuída; nesses casos, é permitida a comercialização direta para o consumidor ou para concessionárias (SENAI, 2016), permitindo o retorno financeiro ao empreendedor, pois é capaz de remunerar a energia vendida.

Para isso, o Ambiente de Contratação Livre é uma das alternativas. Deve-se realizar contratos de compra e venda de energia com consumidores livres, registrados na Câmara de Comercialização de Energia Elétrica (CCEE), com preços negociados e em quantidade limitada à garantia física da planta. A intermediação ou o próprio contrato de venda podem ser realizados com uma empresa comercializadora (GEHRING, 2014; SENAI, 2016). Nessa modalidade, os preços estão sujeitos à competição e à variação no mercado e podem acrescentar incerteza no planejamento da receita de longo prazo do empreendedor.

Outra opção é o Mercado Regulado, que permite a contratação de energia por meio de leilões realizados pela CCEE, geralmente direcionados para o tipo de fonte. São estipulados preços-teto específicos para competição pelo preço mais baixo de fornecimento, com contratos de longo prazo com a tarifa sendo reajustada anualmente pelo IPCA (GEHRING, 2014; SENAI, 2016).

\section{- Plantas em operação e projetos}

Segundo a ANEEL (2017), a potência instalada de geração de energia elétrica a partir do biogás de resíduos urbanos no Brasil é de 127,7 MW, proveniente de 16 usinas. São ainda cadastradas 11 usinas de biogás de resíduos agropecuários, com potência total de 2,1 MW.

Em termos de capacidade de geração, os maiores projetos são: a Termoverde Caieiras, instalada em aterro sanitário na Grande São Paulo, inaugurada em 2016, de 29,5 MW (EBC, 2016); o aterro da São João Biogás, de 24,6 MW, e a Termoverde Salvador, de 19,7 MW. Os dois maiores projetos, portanto, estão no estado de São Paulo, que tem sete plantas somando 70,3 MW (ANEEL, 2017). 
O biogás de vinhaça, por sua vez, teve projeto aprovado no $23^{\circ}$ Leilão de Energia Nova A-5, em 2016. A empresa Raízen se comprometeu com um projeto, na usina Bonfim, de 20,9 MW de potência, a um Índice de Custo Benefício de R \$ 251,00 - valor do período do leilão (CCEE, 2016).

Entre outros, Senai (2016) apresenta projetos em estações de tratamento de efluentes de 1,5 e 2,4 MW para autoconsumo, e Bley Jr. (2015) descreve o projeto da GEO Energética, de $4 \mathrm{MW}$, que reaproveita resíduos de usina de açúcar e álcool, e projetos de pequeno porte como em granjas, abatedouros de aves, e sistemas de produção de leite.

Conclui-se que a geração de energia elétrica a partir do biogás é uma alternativa estabelecida, em diferentes escalas, que vem ganhando em possibilidades de comercialização, o que pode contribuir para viabilizar futuros projetos.

\subsubsection{Regulação e incentivos para produção de biometano}

A Agência Nacional do Petróleo, Gás Natural e Biocombustíveis (ANP), estabeleceu, na resolução ANP nº de 2015, a especificação da qualidade do biometano oriundo de produtos e resíduos orgânicos agrossilvopastoris, ou seja, das atividades agropecuárias e silviculturais, e comerciais, permitindo que fosse misturado ao gás natural.

Naquele momento, a ANP impediu a comercialização de biometano que não atendesse às especificações e que fosse oriundo de resíduos sólidos urbanos e de esgotamento sanitário, a não ser em caráter experimental, que deveria seguir, então, a resolução ANP n²3 de 2012. De acordo com a Nota Técnica (NT) nº 157 de 2014 da agência, a preocupação com o teor máximo permitido de siloxanos e halogenados, e com a falta de metodologia analítica para medição desses componentes foram determinantes para impedir, então, a regulamentação de biometano proveniente dessas fontes (ANP, 2014).

Mesmo com essa limitação, e com o ônus ao produtor de realizar análises em linha e de emitir comprovação de que o biometano atende à especificação, a resolução foi um marco importante. Trata-se de uma regulamentação direcionada para o biometano, que esclareceu a qualidade requerida para o biometano e, não menos importante, o estágio de evolução da compreensão da agência reguladora em relação às características técnicas desse biocombustível. 
Em 2017, a ANP realizou consulta pública para regulamentar a comercialização do biometano proveniente de resíduos sólidos urbanos e estações de tratamento de esgoto. Na NT nº3 de 2017, incluída na consulta, é proposto um modelo de regulação contendo uma parte prescritiva e outra proativa. Ou seja, deve-se combinar o estabelecimento de limites com a análise de risco específica para o empreendimento, em relação aos compostos de siloxanos e halogenados (ANP, 2017).

A análise de risco específica, baseada na experiência de regulação do Reino Unido, justifica-se pelas possíveis diferenças entre os empreendimentos. A qualidade do biogás pode ser alterada, por exemplo, de acordo com o controle da matéria-prima, possível de ser realizado no tratamento mecânico-biológico e incomum em aterros sanitários (ANP, 2017); as características regionais dos resíduos também modificam a composição do gás.

Portanto, em dois anos a partir da publicação da primeira resolução para o biometano, caminha-se para a regulação de todas as fontes desse combustível para comercialização no Brasil, em termos de qualidade. Esses passos são importantes para o desenvolvimento dessa indústria, pois permitem que as plantas sejam projetadas para atender aos requisitos determinados e dão garantias ao consumidor.

O desafio, portanto, passa a ser reduzir os custos do processo de regulação para a agência e para o produtor. A viabilidade desse combustível para o país e dos projetos individuais de produção de biometano é dependente desses custos.

Os estados do Rio de Janeiro e de São Paulo, no ano de 2012, aprovaram iniciativas que propõe a mistura do biometano - na legislação carioca chamado de gás natural renovável - ao gás natural. A “Política Estadual de Gás Natural Renovável” do Rio de Janeiro estabeleceu que (ALERJ, 2012):

As concessionárias de distribuição de gás canalizado do Estado do Rio de Janeiro ficam obrigadas a adquirir, de forma compulsória, todo o Gás Natural Renovável - GNR, produzido no Estado até o limite de 10\% do volume de gás natural convencional distribuído por cada uma delas, não incluído o volume destinado ao mercado termelétrico.

Entre os princípios em que se baseia a política estão o estímulo à participação do biogás na matriz energética estadual e à "disposição final adequada de resíduos orgânicos”, a redução da produção de gases de efeito estufa e a "descentralização e interiorização da economia" (ALERJ, 2012). 
Em São Paulo, com objetivos similares, como ampliar a participação de energias renováveis e aproveitar as "externalidades positivas da geração de gases combustíveis provenientes da biomassa", foi instituído o "Programa Paulista de Biogás". O programa tem como meta "estabelecer a adição de um percentual mínimo de Biometano ao gás canalizado e comercializado no Estado" (ALESP, 2012).

O objetivo das duas propostas, após cinco anos, ainda não foi cumprido; nenhum dos dois estados implementou, de fato, mistura obrigatória de biometano no gás natural, até o término desta dissertação. A realização dessa medida é complexa: o gás natural distribuído pelas concessionárias estaduais tem concorrentes, como o gás liquefeito de petróleo (GLP). A imposição de suprir parte do seu mercado com um produto possivelmente mais caro é preocupante para as empresas, e a mistura obrigatória pode sofrer com esse tipo de resistência.

Recentemente, no entanto, o estado de São Paulo tem realizado avanços. A Agência Reguladora de Saneamento e Energia do Estado de São Paulo (ARSESP) publicou, em julho de 2017, a Deliberação $n^{\circ}$ 744, que estabelece "condições e critérios para distribuição de biometano na rede de gás canalizado, no âmbito do Estado de São Paulo”. Baseando-se nas especificações da ANP, responsabilizando o fornecedor pela qualidade na entrega à concessionária de distribuição de gás canalizado, e a concessionária pelo monitoramento em linha, a regulação trata, entre outros aspectos (ARSESP, 2017):

- das cláusulas essenciais dos contratos de compra e venda nos mercados regulado e livre, como volume contratado e preço do biometano por metro cúbico;

- da solicitação pública de propostas de compra de biometano pelas concessionárias, que deve ser realizada anualmente até atingido percentual mínimo para aquisição de biometano, quando este for estabelecido;

- da participação no mercado livre;

- da expansão da rede, limitada na regulação à viabilidade econômico-financeira do investimento para a concessionária ou, caso inviável, "com participação financeira do fornecedor e/ou demais interessados".

Segundo a Arsesp (2016), o estabelecimento de percentual mínimo de biometano e do preço teto de aquisição devem ser tratados pelo governo, e não pela agência reguladora. $O$ responsável seria o Comitê Gestor do Programa Paulista de Biogás, que, segundo a lei de 2012, deveria ser criado (ALESP, 2012), o que ocorreu em março de 2017 (SECRETARIA DE ENERGIA E MINERAÇÃO, 2017). 
Ainda, o desenvolvimento do biometano pode se beneficiar de mudanças no setor de gás natural. A iniciativa "Gás para Crescer”, colocada em consulta pública em outubro de 2016, tem como objetivo aprimorar o "arcabouço normativo do setor de gás, tendo em vista a redução da participação da Petrobras nesse setor". É proposto, entre outras ações, "redefinir a estrutura da indústria de gás natural, através da promoção de maior diversidade no número de agentes comercializando gás natural". A ABiogás também é citada como agente que contribuiu na construção da proposta (BRASIL, 2016b).

\section{- Plantas em operação e projetos}

Entre os projetos de produção de biometano, destaca-se o gás de aterro como matériaprima. No estado do Rio de Janeiro há dois empreendimentos do tipo em operação, um no aterro de Gramacho e outro no aterro Dois Arcos, em São Pedro da Aldeia. Ambas foram visitadas pelo autor no desenvolvimento deste trabalho, em setembro de 2016.

O aterro de Gramacho, que fica próximo às margens da Baía de Guanabara e área de manguezal, era um lixão que foi recuperado em um projeto que envolveu a captura do gás. Operada pela Gás Verde S/A, a planta fornece biometano para a Refinaria Duque de Caxias (REDUC) e, pela proximidade das unidades, utilizam um gasoduto dedicado. Foi reportado que a refinaria consumia $49 \mathrm{mil} \mathrm{m}^{3}$ de biogás, correspondente a 2,5\% do seu consumo de gás natural, e que o projeto previa ser capaz de reduzir em $10 \%$ o consumo de gás natural da refinaria (PETROBRAS, 2014). No entanto, em visita ao empreendimento, foi constatado que a planta opera apenas parcialmente em relação à sua capacidade, pela baixa quantidade de gás produzido e impossibilidade de receber mais resíduos que poderiam aumentar essa oferta.

$\mathrm{O}$ aterro Dois Arcos, por sua vez, continuava em atividade, recebendo novos resíduos. A planta, operada pela empresa Ecometano e inaugurada em 2014, utiliza um sistema de lavagem

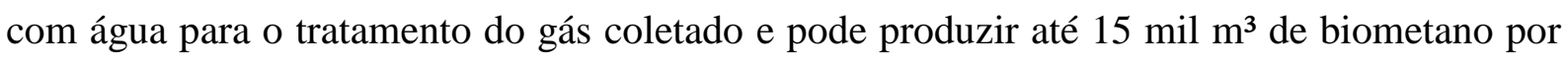
dia (ECOMETANO, 2017). Devido a resolução ANP nº de 2015, que impediu a injeção nas redes de gás natural do biometano proveniente de resíduos urbanos, a empresa buscou outras soluções para comercializar o seu produto, como a distribuição em cilindros diretamente para clientes.

A experiência dos dois empreendimentos, e de outros projetos, contribuiu para o conhecimento da ANP e para a formulação de propostas para desenvolver a regulação da qualidade do biometano, especialmente de aterros (ANP, 2017). 
A empresa Ecometano também está envolvida em outros projetos, como um aterro no Ceará e outro no Espírito Santo, com capacidade para produção de $100 \mathrm{mil} \mathrm{m}^{3}$ e $60 \mathrm{mil} \mathrm{m}^{3}$ de biometano por dia, respectivamente, segundo divulgação da própria companhia. Ambos estão em fase de implantação (ECOMETANO, 2017).

Outro projeto anunciado é uma parceria para a produção de biometano a partir da vinhaça, este no estado de São Paulo. A empresa GasBrasiliano, uma das concessionárias de distribuição de gás do estado de São Paulo, anunciou que comprará o biometano produzido a partir da vinhaça fornecida de usina da Malosso Bioenergia. A produção estimada de biometano é de 5 milhões de $\mathrm{m}^{3}$ por ano, correspondente a $14 \mathrm{mil} \mathrm{m}^{3}$ diários, em média (GASBRASILIANO, 2015).

Bley Jr. (2015) cita, ainda, o Consórcio Verde Brasil em Montenegro/RS e a usina de gás renovável em Pomerode/SC, que produzem biometano a partir de resíduos agroindustriais e da criação de animais.

Portanto, há também exemplos de empreendimentos que produzem biometano no Brasil. Nota-se, no entanto, que há barreiras em relação à regulação e possibilidade de comercialização desse produto.

\subsection{Propostas referentes à utilização do biogás}

Um documento relevante é a "Proposta de Plano Nacional do Biogás e do Biometano" (PNPB), publicado em 2015 por atores do setor por meio da Associação Brasileira do Biogás e do Biometano - ABiogás. A proposta é da criação de um programa do governo federal para "promover no Brasil um cenário institucional, econômico, normativo e regulatório, que proporcione condições favoráveis e estáveis necessárias para referenciar, estimular e assegurar a produção e aplicações do biogás e do biometano" (ABIOGÁS, 2015, p. 31).

A ABiogás lista dezessete "diretrizes" do plano proposto. Entre elas, estão incluídas, por exemplo, questões relacionadas à pesquisa, capacitação e investimentos no setor. Na Tabela 14 são identificadas sete diretrizes diretamente relacionadas ao uso da energia do biogás, divididas de acordo com sua correspondência com a produção de biometano, de energia elétrica ou ambos. 
Tabela 14 - Objetivos do PNPB identificados em relação ao uso do biogás

\begin{tabular}{|c|c|c|}
\hline Ambos os usos & Biometano & Energia elétrica \\
\hline $\begin{array}{l}\text { Utilizar o biogás e o biometano } \\
\text { como fonte complementar à oferta } \\
\text { interna de energia térmica, } \\
\text { elétrica e combustível }\end{array}$ & $\begin{array}{l}\text { Reduzir a necessidade de } \\
\text { importação de óleo diesel, GLP } \\
\text { e gás natural na matriz } \\
\text { energética brasileira }\end{array}$ & $\begin{array}{l}\text { Melhorar a } \\
\text { confiabilidade da } \\
\text { distribuição da energia } \\
\text { elétrica no sistema }\end{array}$ \\
\hline $\begin{array}{l}\text { Difundir o conceito de Geração } \\
\text { Distribuída de Energia Elétrica e } \\
\text { Produção Descentralizada de } \\
\text { Combustível }\end{array}$ & $\begin{array}{l}\text { Difundir o conceito de } \\
\text { intercambiabilidade }(\mathrm{sic}) \text { de } \\
\text { biometano nas redes de } \\
\text { distribuição de gás natural } \\
\text { observando limitações regionais } \\
\text { e em conformidade com a } \\
\text { regulamentação da ANP }\end{array}$ & - \\
\hline $\begin{array}{l}\text { Estabelecer segurança normativa } \\
\text { a longo prazo para atrair e } \\
\text { viabilizar investimentos na } \\
\text { produção e aplicações energéticas } \\
\text { do Biogás e do Biometano e } \\
\text { visando a proteção do consumidor } \\
\text { das energias geradas com biogás e } \\
\text { biometano, baseada nas suas } \\
\text { qualidades e oferta firme }\end{array}$ & $\begin{array}{l}\text { Trabalhar com a ANP, } \\
\text { ABEGÁS e com os Governos } \\
\text { Estaduais para regulamentar o } \\
\text { swap de biometano entre redes } \\
\text { de distribuição e transporte de } \\
\text { gás natural }\end{array}$ & - \\
\hline
\end{tabular}

Fonte: elaborado a partir de ABiogás (2015, p. 31-32)

Nota-se que a proposta da ABiogás visa ao desenvolvimento da utilização de biogás para as duas alternativas: a produção de energia elétrica e de biometano. Ou seja, não há escolha por apenas uma opção. Em ABiogás (2015), ao mesmo tempo que se propõe incentivos ao biometano, é sugerido que seja contratada energia elétrica por meio de leilões regulares.

No entanto, entre as diretrizes apresentadas na Tabela 14, há maior foco nas demandas para viabilizar o biometano no país, em detrimento da produção de energia elétrica pelo biogás: são três diretrizes específicas para o biometano e apenas uma específica para energia elétrica. Nesse caso, a explicação pode ser a maior quantidade de barreiras regulatórias associadas ao biometano como estratégia de utilização.

Este autor avalia que os interesses reunidos na ABiogás sugerem que não deverá partir dessa organização uma iniciativa de direcionar o setor para um uso. Na associação, empresas de equipamentos para geração de energia elétrica estão ligadas a empresas com interesse na produção e uso de biometano. Até certo ponto, os interesses das empresas são convergentes. No entanto, podem também ser consideradas concorrentes pois, de forma geral, a presença de 
uma tecnologia em um projeto exclui a presença da outra. A participação ativa da ABiogás tem indicado que suas posições podem ter influência direta no desenvolvimento do biogás no Brasil; é importante que elas sejam acompanhadas para se compreender os possíveis rumos do setor.

O Projeto Brasil-Alemanha de Fomento ao Aproveitamento Energético de Biogás no Brasil (Probiogás), também apresentou suas propostas para o mercado de biogás no Brasil, após identificar as principais barreiras (PROBIOGÁS, 2016a). O projeto é fruto de parceria entre o Ministério das Cidades e a Deutsche Gesellschaft für Internationale Zusammenarbeit GmbH (GIZ), agência alemã de cooperação internacional.

As propostas finais, baseadas em análises de entrevistas realizadas com empresas e instituições, se organizaram em oito grupos principais:

a) tarifa diferenciada para geradores a biogás por tempo determinado;

b) incentivos fiscais e tributários;

c) promoção de linhas de financiamento para o biogás e acesso a recursos públicos federais;

d) fomento ao uso de recursos dos Fundos Setoriais para implantação de projetos referência na área de biogás;

e) desenvolvimento de uma política setorial estruturante para o biogás;

f) estruturação de incentivos e subsídios do setor elétrico e de gás natural;

g) financiamento e regularização ambiental dos empreendimentos de biogás;

h) fortalecimento da capacitação e formação na área de biogás.

Pode-se identificar que apenas duas estão diretamente ligados ao uso: as propostas (a) e (f). No âmbito da proposta (a), o estudo sugere manter o valor de R \$633,94/MWh para contratação de geração própria de unidade consumidora por sete anos, correspondente ao período de retorno do investimento. É proposto também um limite de $2 \mathrm{GW}$ de potência instalada nesse esquema e, com o máximo por planta em 1 MW (PROBIOGÁS, 2016a).

A proposta (f) sugere, em relação ao setor elétrico: a criação de uma câmara de comércio de biogás, biometano e seus produtos; a diferenciação do preço da energia elétrica nos leilões do Ambiente de Contratação Regulado; o aumento da potência máxima para enquadramento no sistema net metering; a permissão da comercialização de energia excedente no Ambiente de Contratação Livre; e o desenvolvimento de modelos de negócio como o net metering para horários de ponta, para contornar o problema das baixas tarifas (PROBIOGÁS, 2016a). 
Em relação ao biometano, a proposta (f) contempla: a exigência de injeção de percentual mínimo de biometano ao gás natural; a permissão da venda direta ao consumidor, como em um mercado livre; a construção de redes de baixa pressão para a distribuição de biogás/biometano; a criação de certificação de origem do biometano para nichos de mercado "verdes"; permissão de redes dedicadas independentes das distribuidoras, que permitiriam negociação direta e contornar as exigências de qualidade da ANP (PROBIOGÁS, 2016a).

Nas propostas do Probiogás (2016a), nota-se o aprofundamento nas questões relacionadas ao setor elétrico, e soluções relativamente genéricas para o biometano. Nesse caso, pode-se avaliar essa diferença pelos mecanismos já existentes de geração distribuída e leilões no setor elétrico e que precisam de aperfeiçoamento para o desenvolvimento do biogás, enquanto o mercado para o biometano é muito incipiente e carente de mecanismos de comercialização da energia.

Entre os diagnósticos de Mariani et al. (2014), ao avaliar iniciativas do setor de biogás, é apontado o fato de que apesar de terem objetivos convergentes, elas não são coordenadas. Os autores concluem que é importante "se pensar uma política pública em nível nacional para o biogás, que agregue ações que vêm sendo realizadas, analise resultados positivos e negativos de ações passadas e planeje, conjuntamente, o caminho a ser seguido".

Segundo Mariani et al. (2014), essa política deveria ser liderada pelo Ministério de Minas e Energia (MME), e promover a interação com as políticas ambientais, energéticas, agrícolas e urbanas, com os governos estaduais, entre outros interessados, para maximizar os ganhos econômicos, ambientais e sociais que o biogás pode proporcionar. Não há referência, nessa análise, à seleção de um uso prioritário para o biogás.

Da mesma forma, falando do setor do biogás como um todo, Zanette (2009) destaca “o baixo grau de coordenação entre os órgãos responsáveis pela elaboração de políticas ambientais, energéticas, agrícolas e urbanas", e sugere melhor interação para o efetivo aproveitamento do potencial energético do biogás.

Veiga (2016), ao analisar as condições necessárias ao sucesso do aproveitamento de biometano proveniente de aterros sanitários no Brasil, também notou a importância da articulação entre as políticas do setor energético e de saneamento, além de políticas de incentivo e da implantação dos planos existentes.

Na prática, sabe-se que a diversidade de interesses é intrínseca ao biogás, e muitas vezes eles são comuns entre os setores; portanto, esse fato não é necessariamente um problema. A 
questão passa a ser a necessidade de haver um setor responsável por uma iniciativa agregadora para que, principalmente, se defina a fonte de recursos (financeiros, humanos, etc.) para um programa para desenvolver o biogás no Brasil. A busca pela solução dessa questão passa pela identificação, portanto, de quais setores mais podem se beneficiar do biogás e poderiam assumir esse compromisso.

Seguindo a ideia de Mariani et al. (2014), o MME, representando o setor energético, poderia ser o líder da iniciativa. Mesmo assim, a diversidade de setores e políticas, como as do setor elétrico e as direcionadas ao biometano, continua existindo, como foi mostrado ao longo deste trabalho. E, nesse caso, os interesses não são necessariamente convergentes.

Reitera-se que a sugestão e discussão levantadas neste trabalho são de que o desenvolvimento do setor de biogás pode passar pela escolha de uma forma de utilização que catalise as iniciativas e as direcione para si. Apesar das apresentadas controvérsias e da dificuldade de análise para desenvolver uma estratégia de longo prazo, é uma sugestão baseada nas experiências internacionais de ponta e que pode ajudar a resolver barreiras amplamente citadas nos estudos do setor no país.

No entanto, nem o próprio autor está absolutamente convencido de que essa sugestão deveria ser adotada; está sim convencido de que, para aprofundar a discussão sobre a utilização de biogás, seja para direcioná-la ou para nivelar as condições entre as estratégias, as análises aqui apresentadas são importantes. Enfatizam essa relevância a influência de políticas orientando a utilização do biogás nas bem-sucedidas experiências alemã e sueca. Faz-se a ressalva, ainda, da diferença dos países avaliados - Suécia e Alemanha - para o Brasil, tanto em termos das características do setor de biogás e de resíduos, como na capacidade de planejamento e instrumentalização de políticas.

A sugestão é de que se continue a avaliar as características tecnológicas, os custos, e as oportunidades de inserção de cada alternativa no setor energético. Ainda, que se analise os benefícios e problemas de se estimular um "uso prioritário", que se estude experiências internacionais distintas e sob outros pontos de vista, e que seja quantificado e debatido qual o direcionamento que os incentivos estão, atualmente, impondo ao setor. Espera-se a contribuição de outros autores para o enriquecimento da discussão.

No entanto, por poder contrariar interesses, por requerer esforços para seu planejamento e sua implementação - além da avaliação deste autor sobre o contexto atual - considera-se provável que a escolha de um "uso prioritário" não seja adotada no setor de biogás do Brasil. 


\section{CONCLUSÕES E SUGESTÕES PARA TRABALHOS FUTUROS}

Como forma de contribuir com o desenvolvimento do setor de biogás no Brasil, foi proposta, nesta dissertação, a adoção de um “uso prioritário" entre as alternativas de geração de energia elétrica e a produção de biometano. Este uso, identificado pelo planejamento e baseado nas características da fonte e do setor energético do país, concentraria em si os incentivos e os esforços de um programa para o biogás.

Foi avaliado que essa estratégia teria a capacidade de ajudar na solução de questões-chave apontadas como barreiras do setor. A começar por ser uma política específica, que poderia gerar experiência em projetos com arranjos tecnológico e comercial determinados, reduzindo a percepção de riscos e criando um mercado relacionado à alternativa incentivada.

A própria existência de incentivos é apresentada como um argumento importante para que se avalie as alternativas de utilização. Ao se formular uma política para o desenvolvimento da bioenergia, é necessário visão e objetivos claros. Uma análise adequada da intenção que o planejamento do setor energético tem em relação à energia do biogás é primordial para a formulação dos incentivos adequados e para que possam ser sustentáveis no longo prazo.

A falta de uma política de direcionamento pode fazer com que o desenvolvimento de cada alternativa sofra com a concorrência entre elas, dificultando o avanço na curva de aprendizado, a criação de uma indústria própria, e a redução de custos de ambas. Além disso, elas competem entre si por um potencial energético limitado, ainda mais se considerado apenas o economicamente viável. A divisão nas duas formas de utilização pode atrapalhar a percepção do potencial pelos formuladores de política, impedindo planos mais ambiciosos de crescimento da fonte em cada setor.

Ainda, caso não haja planejamento, o direcionamento do uso do biogás pode ser feito de forma "aleatória", pois os setores de energia elétrica e de gás natural, correspondente ao do biometano, tem seus próprios mecanismos de comercialização e incentivos, o que cria barreiras ou abre caminhos para o desenvolvimento de cada alternativa. Portanto, ainda que se busque a neutralidade entre as duas tecnologias, deve-se avaliar os mecanismos de estímulo e as barreiras em vigor e buscar nivelá-los.

Por outro lado, há desvantagens nessa estratégia, justamente por ser uma intervenção política direcionando o mercado e por ser intrínseca a ela certo menosprezo à flexibilidade 
característica da utilização do biogás, que pode ter, para a condição específica de cada planta, uma opção mais adequada.

Para avaliar a consistência prática dessa proposta, a evolução dos sistemas de biogás da Alemanha e da Suécia foram avaliados. A Alemanha, direcionada por tarifas feed-in de eletricidade, tem seu sistema baseado na geração de energia elétrica. Ao longo do tempo, foram criados incentivos para aumentar a eficiência do seu sistema, incluindo o aproveitamento do calor residual do processo - caracterizando a cogeração. Mais recentemente, a produção de biometano também foi estimulada e apresentou crescimento; o desenho desses estímulos também tinha como objetivo a cogeração de energia elétrica e calor, em locais em que havia demanda por energia térmica.

A característica do sistema sueco, por outro lado, é da produção de biometano para uso veicular. Notou-se que, novamente, os incentivos do governo, em várias partes da cadeia de produção e distribuição do combustível, foram a principal causa desse direcionamento.

A análise dos países mostrou que a Alemanha incentivou várias fontes renováveis no setor elétrico, incluindo o biogás, visando a redução da geração por energia nuclear e por fontes fósseis. A Suécia, por outro lado, apresenta uma base hidroelétrica e nuclear, sem o objetivo de reduzir no curto prazo a participação destas fontes, e direcionou o biometano para o setor de transportes. Foi avaliado que o contexto do setor energético do país é importante na decisão da estratégia para a utilização do biogás.

Por fim, realizada a comparação entre as estratégias para o Brasil, para ambas foram identificadas oportunidades e barreiras.

A produção de biometano tem oportunidade de substituir importações de gás natural, especialmente em um contexto de expiração dos contratos de compra do gás da Bolívia e em que as importações de GNL - de forma geral, mais caras que o produto boliviano - têm tido grande relevância na oferta. No entanto, o biometano compete apenas com a parte estável da demanda por gás natural, enquanto o GNL tem o papel de suprir uma variabilidade causada pela demanda termoelétrica. A infraestrutura de gás, concentrada nos centros urbanos, pode resultar em dificuldades para o aproveitamento do potencial distribuído da geração de biogás e, portanto, do biometano. Por outro lado, o biometano pode suprir uma demanda pouco acessível ao gás natural e desenvolver infraestrutura própria e interiorizada.

A geração de energia elétrica, por outro lado, sofreria com a concorrência de outras fontes renováveis de preços competitivos e grande potencial. A possibilidade de geração firme e 
flexível do biogás é apontada como uma característica a ser considerada como diferencial, que pode viabilizar o desenvolvimento da fonte nesse setor.

Em termos de custo, a produção de biometano apresenta redução acentuada de custos específicos de instalação com o aumento da escala das unidades, e a variação continua mesmo entre plantas de grande porte. A geração de energia elétrica mostra similar em escalas pequenas, mas os custos por potência instalada tendem a se estabilizar, não apresentando reduções importantes a partir de certo tamanho.

As questões de preço e infraestrutura apontam para a conclusão que o foco da produção de biometano pode estar em unidades de grande capacidade, enquanto a geração de energia elétrica pode ser estimulada em pequena escala.

A avaliação de aspectos ambientais mostra que, nas duas alternativas, há o risco de perdas de eficiência no processo e diminuição das externalidades positivas. A geração de eletricidade, se realizada sem aproveitamento do calor residual - na forma de cogeração -, apresenta perda de grande parte da energia do biogás. A produção de biometano, por sua vez, tem como pontos negativos o consumo de energia no processo de upgrading e a perda de metano, cuja emissão direta deve ser evitada. A regulação ou a criação de estímulos para o melhor aproveitamento da energia e para a adoção de processos eficientes pode ter consequências positivas.

Por fim, a avaliação do contexto, de incentivos em vigor e de propostas do setor de biogás apontam que não é provável que seja implementado um programa que explicitamente ou propositalmente direcione o uso para energia elétrica ou biometano; não é uma proposta de nenhum órgão ou estudo - que tenha sido possível identificar. Na prática, entende-se que ainda não foi divulgada a sugestão de um "uso prioritário", da forma e com o enfoque argumentado nesta dissertação. Também não foi possível concluir que a utilização de biogás esteja, atualmente, orientada para apenas uma das estratégias. Há projetos de geração de energia elétrica e de biometano e desenvolvimento no âmbito regulatório de ambas as opções. No entanto, considerou-se que o biometano tem alternativas de comercialização menos consolidadas, e não foi encontrado incentivo direto para venda de biometano.

Sugere-se, para trabalhos futuros, que se continue a discussão sobre as vantagens e desvantagens de uma estratégia que priorize uma alternativa de aproveitamento da energia do biogás, e quais as possíveis consequências para o setor; a visão e contribuição de outros autores pode enriquecer os argumentos. A avaliação dos incentivos existentes no Brasil, de forma quantitativa, se possível, poderia contribuir com propostas de novas políticas. Ainda, devem ser 
realizadas análises de experiências internacionais diferentes dos sistemas de biogás da Alemanha e da Suécia, especialmente de países com mais semelhanças com o caso brasileiro tanto no setor de biogás e resíduos quanto na capacidade de planejamento e execução de políticas. Mesmo novas avaliações dos casos alemão e sueco, sob o enfoque do aproveitamento energético e seu desenvolvimento, e a relação das estratégias para o biogás com o contexto do setor energético de cada país, podem identificar questões que, eventualmente, não tenham sido contempladas.

Para a comparação e análise sobre a melhor estratégia para o biogás no caso brasileiro, há diversas sugestões que poderiam ter relevante contribuição. Primeiramente, notou-se a dificuldade de identificar dados que possam ser considerados "definitivos" para o potencial energético do biogás no país. O levantamento destes dados, especialmente se realizado de forma a diferenciá-los em suas características, como a matéria-prima, a escala de aproveitamento e a localização geográfica, teriam consequências muito positivas para a análise. A avaliação do potencial em conjunto com a infraestrutura do setor energético seria uma ferramenta conveniente para a visualização e o planejamento do aproveitamento do biogás.

A obtenção de dados de custos médios de geração de energia elétrica e de produção de biometano, separado por fontes e por escala seria essencial para a comparação com as fontes concorrentes dos respectivos setores, e para a utilização dos dados de potencial energético para cálculo do potencial economicamente viável. Assim, seria possível, por exemplo, simular cenários de substituição de outras fontes, no caso do setor elétrico, e de importações, no caso do biometano no setor de gás natural. 


\section{REFERÊNCIAS}

AAAS. What we know: The reality, risks, and response to climate change. American Association for the Advancement of Science (AAAS) Climate Science Panel, 2014. Disponível em: <http://whatweknow.aaas.org/wpcontent/uploads/2014/07/whatweknow_website.pdf>. Acesso em: 02 jun. 2017.

ABATZOGLOU, N.; BOIVIN, S. A review of biogas purification processes. Biofuels, Bioproducts \& Biorefining, n. 3, p. 42-71, 2008.

ABC. Biogas 101 Handout. American Biogas Council (ABC). Washington, DC. 2016. ABEEÓLICA. Boletim anual de geração eólica 2016. Associação Brasileira de Energia Eólica (ABEEólica). São Paulo. 2017.

ABIOGÁS. Proposta de Programa Nacional do Biogás e do Biometano PNBB - Versão 1. Associação Brasileira de Biogás e Biometano, 2015. Disponível em:

<http://www.abiogas.org.br/>. Acesso em: 01 ago. 2017.

ABREU, F. V. D. Biogás: economia, regulação e sustentabilidade. 1. ed. Rio de Janeiro: Interciência, 2014.

ACENDE BRASIL. White Paper - Transmissão: o elo integrador. Edição n⿳ 15. Instituto Acende Brasil - O observatório do setor elétrico brasileiro. 2015.

ACENDE BRASIL. White Paper - $O$ mercado de gás natural e a geração termelétrica. Edição no 16. Instituto Acende Brasil - O observatório do setor elétrico brasileiro. 2016.

AJHAR, M. et al. Siloxane removal from landfill and digester gas - A technology overview. Bioresource Technology, n. 101, p. 2913-2923, 2010.

ALERJ. Lei n 6.361, de 18.12.2012. Dispõe sobre a Política Estadual de Gás Natural Renovável - GNR. Assembléia Legislativa do Estado do Rio de Janeiro (ALERJ). 2012.

ALESP. Decreto $n^{\circ}$ 58.659, de 4.12.2012. Assembléia Legislativa do Estado de São Paulo, 2012.

ANEEL. Resolução Normativa no 271, de 3 de julho de 2007. Agência Nacional de Energia Elétrica (ANEEL). 2007.

ANEEL. Atlas de energia elétrica do Brasil. Agência Nacional de Energia Elétrica (ANEEL). Brasília. 2008.

ANEEL. Resolução Normativa no 687, de 24 de novembro de 2015. Agência Nacional de Energia Elétrica (ANEEL). 2015.

ANEEL. BIG - Banco de Informações de Geração. Agência Nacional de Energia Elétrica (ANEEL), 2017.2 Disponível em: <http://www2.aneel.gov.br/aplicacoes/capacidadebrasil/CombustivelListaUsinas.asp>. Acesso em: 05 jul. 2017. 
ANP. Resolução ANP no 16, de 17.6.2008 - DOU 18.6.2008. Agência Nacional do Petróleo, Gás Natural e Biocombustíveis, 2008.

ANP. Nota técnica $\mathbf{n}^{\mathbf{0}}$ 157/2014/SBQ/RJ. Agência Nacional do Petróleo, Gás Natural e Biocombustíveis (ANP). Rio de Janeiro. 2014.

ANP. Resolução ANP nº 8, de 30.1.2015 - DOU 2.2.2015. Agência Nacional do Petróleo, Gás Natural e Biocombustíveis, 2015.

ANP. Nota técnica no 03/2017/SBQ/RJ. Agência Nacional do Petróleo, Gás Natural e Biocombustíveis (ANP). Rio de Janeiro. 2017.

ARASTO, A. et al. Bioenergy's role in balancing the electricity grid and providing storage options - an EU perspective. International Energy Agency (IEA) Bioenergy. 2017.

ARCADIS TETRAPLAN. Resumo Executivo: Estudo sobre o Potencial de Geração de Energia a partir de Resíduos de Saneamento (lixo, esgoto), visando incrementar o uso de biogás como fonte alternativa de energia renovável. Arcadis Tetraplan S.A.; Programa das Nações Unidas para o Desenvolvimento (PNUD); Ministério do Meio Ambiente (MMA). São Paulo. 2010.

ARSESP. Nota técnica NTG n 004/2016. Apresentada na Consulta Pública no 07/2016. Agência Reguladora de Saneamento e Energia do Estado de São Paulo (ARSESP). 2016.

ARSESP. Deliberação Arsesp n⿳0 744 de 2017. Dispõe sobre as condições de distribuição de Biometano na rede de gás canalizado no âmbito do Estado de São Paulo, e dá outras providências. Agência Reguladora de Saneamento e Energia do Estado de São Paulo (ARSESP). 2017.

AZAR, C.; SANDÉN, B. The elusive quest for technology-neutral policies. Environmental Innovation and Societal Transitions, v. 1, p. 135-139, 2011.

BANCO CENTRAL DO BRASIL. Taxas de câmbio: cotações e boletins. Câmbio e capitais internacionais - Banco Central do Brasil. Disponível em: <http://www4.bcb.gov.br/pec/taxas/port/ptaxnpesq.asp?id=txcotacao>. Acesso em: 07 ago. 2017.

BANKS, J.; ALLOTT, K. Why governments must pick the right energy policy 'winners'. The Guardian, London, Outubro 2012.

BARREIRA, P. Biodigestores: energia, fertilidade e saneamento para a zona rural. $3^{\mathrm{a}}$. ed. São Paulo: Ícone, 2011.

BARUFI, C.; SANTOS, E.; IDE, C. Auto-suficiência energética e desenvolvimento: o comércio de gás natural entre Brasil e Bolívia. Cadernos PROLAM/USP, v. 2, p. 183-208, 2006.

BERMANN, C. Energia no Brasil: para quê? Para quem? 2a. ed. São Paulo: Livraria da Física, 2001. 
BERNAL, A. P. et al. Vinasse biogas for energy generation in Brazil: An assessment of economic feasibility, energy potential and avoided $\mathrm{CO}_{2}$ emissions. Journal of Cleaner Production, v. 151, p. 260-271, 2017.

BLEY JR., C. Biogás: a energia invisível. $2^{\mathrm{a}}$ ed. rev. e ampl. ed. Foz do Iguaçu: ITAIPU Binacional, 2015.

BORDOFF, J.; DESHPANDE, M.; NOEL, P. Understanding the interaction between Energy Security and Climate Change Policy. In: PASCUAL, C.; ELKIND, J. Energy security: Economics, Politics, Strategies and Implications. Washington, DC: The Brookings Institution, 2010.

BRASIL. Lei $n^{\circ}$ 13.263, de 23 de Março de 2016. Altera a Lei $\mathbf{n}^{\circ}$ 13.033, de 24 de setembro de 2014, para dispor sobre os percentuais de adição de biodiesel ao óleo diesel comercializado no território nacional. Presidência da República - Casa Civil - Subchefia para Assuntos Jurídicos. 2016a.

BRASIL. Gás para crescer: diretrizes estratégicas. Versão beta. ANP; EPE; Ministério de Minas e Energia. 2016b.

BRASIL. RenovaBio: Diretrizes Estratégicas. ANP; EPE; Ministério da Agricultura; Ministério de Minas e Energia. 2016c.

BRASIL. Percentual obrigatório de biodiesel no óleo diesel passa para 8\%. Portal Brasil Governo Federal, 2017. Disponível em: <http://www.brasil.gov.br/economia-eemprego/2017/03/percentual-obrigatorio-de-biodiesel-no-oleo-diesel-passa-para-8>. Acesso em: 07 ago. 2017.

BUDZIANOWSKI, W. M.; BUDZIANOWSKA, D. A. Economic analysis of biomethane and bioelectricity generation from biogas using different support schemes and plant configurations. Energy, v. 88, p. 658-666, 2015.

CARNEVALE, E.; LOMBARDI, L. Comparison of different possibilities for biogas use by Life Cycle Assessment. Energy Procedia, p. 215-226, 2015.

CCEE. $22^{\circ}$ Leilão de Energia Nova A-3 - Resultado Completo. Câmara de Comercialização de Energia Elétrica (CCEE), 2015. Disponível em: 〈https://www.ccee.org.br〉. Acesso em: 02 ago. 2017.

CCEE. $23^{\circ}$ Leilão de Energia Nova A-5 - Resultado Completo. Câmara de Comercialização de Energia Elétrica (CCEE), 2016. Disponível em: <https://www.ccee.org.br>. Acesso em: 02 ago. 2017.

CETESB. Biogás: projetos e pesquisas no Brasil. Companhia de Tecnologia de Saneamento Ambiental (CETESB). São Paulo. 2006.

CETESB. Emissões veiculares no estado de São Paulo 2014. Companhia Ambiental do Estado de São Paulo - CETESB, 2014a.

CETESB. Projetos de biogás no MDL. CETESB. 2. ed. São Paulo. 2014 b. 
CHEN, Q.; LIU, T. Biogas system in rural China: Upgrading from decentralized to centralized? Renewable and Sustainable Energy Reviews, v. 78, p. 933-944, 2017.

CLEARINGSTELLE EEG. Renewable Energy Sources Act EEG 2009. Clearingstelle EEG English, 2009. Disponível em: <https://www.clearingstelle-eeg.de/english〉. Acesso em: 4 ago. 2017.

CLEARINGSTELLE EEG. Renewable Energy Sources Act EEG 2012. Clearingstelle EEG English, 2012. Disponível em: <https://www.clearingstelle-eeg.de/english>. Acesso em: 04 ago. 2017.

COELHO, S. T. et al. Sustentabilidade Ambiental dos Biocombustíveis. In: PERLINGEIRO, C. A. Biocombustíveis no Brasil: Fundamentos, Aplicações e Perspectivas. $1^{\text {a }}$. ed. Rio de Janeiro: Synergia, 2014.

CONAMA. Resolução CONAMA no 375, de 29 de agosto de 2006. Ministério do Meio Ambiente - Conselho Nacional do Meio Ambiente, 2006.

COSTA, D. F. D. Geração de energia elétrica a partir do biogás de tratamento de esgoto. São Paulo: Dissertação (Mestrado) - Programa Interunidades de Pós-Graduação em Energia IEE/EPUSP/FEA/IF, Universidade de São Paulo, 2006.

COSTA, H. K. D. M. A regulação do livre acesso na distribuição de gás natural canalizado: o caso de São Paulo. Dissertação (Mestrado) - Programa Interunidades de Pós-Graduação em Energia, Universidade de São Paulo, São Paulo, 2006.

CRESESB. Atlas do Potencial Eólico Brasileiro. Centro de Referência para Energia Solar e Eólica Sérgio Brito, 2001.

DAVID, A. C. Secagem térmica de lodos de esgoto. Determinação da umidade de equilíbrio. São Paulo: Dissertação (Mestrado) - Escola Politécnica da Universidade de São Paulo, São Paulo, 2002.

DENA. Biogas Grid Injection and Application in Germany and Europe: Market, Technology and Players. Deutsche Energie-Agentur GmbH (DENA) - German Energy Agency. Berlin. 2016.

DEUBLEIN, D.; STEINHAUSER, A. Biogas from waste and renewable resources. Weinheim: Wiley-VCH, 2008.

DEWIL, R.; APPELS, L.; BAEYENS, J. Energy use of biogas hampered by the presence of siloxanes. Energy Conversion \& Management, n. 47, p. 1711-1722, 2006.

DIAS, D. D. S.; RODRIGUES, A. P. A regulação das indústrias de rede: o caso dos setores da infra-estrutura energética. Revista de Economia Política, v. 17, p. 71-84, Julho-Setembro 1997.

DICKSON, D.; ADOMATIS, N. Sweden's deal leaves door to nuclear power open, but only just. Reuters, 2016. Disponível em: <http://www.reuters.com/article/sweden-nuclearpoweridUSL8N19E2VM>. Acesso em: 13 jul. 2017. 
DUARTE, A. C. Projetos de MDL em aterros sanitários no Brasil: alternativa para o desenvolvimento sustentável. Dissertação de mestrado da Engenharia de Recursos Hídricos e Ambiental da Universidade Federal do Paraná. Curitiba. 2006.

DWA. Guia técnico DWA-M 361: Tratamento do Biogás. Deutsche Vereinigung fur Wasserwirtschaft, Abwasser und Abfall e. V. (Associação Alemã de Gestão Hídrica, Efluentes e Resíduos). Hennef. 2011.

EBA. Biogas Report. European Biogas Association (EBA). Brussels. 2014.

EBC. Maior termelétrica com combustível renovável é inaugurada em São Paulo. Empresa Brasileira de Comunicação (EBC), 2016. Disponível em: <http://agenciabrasil.ebc.com.br/economia/noticia/2016-09/maior-termeletrica-comcombustivel-renovavel-e-inaugurada-em-sao-paulo>. Acesso em: 04 jul. 2017.

ECOMETANO. Ecometano - Projetos. Ecometano, 2017. Disponível em: <http://www.ecometano.com.br/ecometano/projetos.html>. Acesso em: 05 jul. 2017.

EIA. International Energy Statistics. Energy Information Administration (EIA), 2017. Disponível em: <https://www.eia.gov/beta/international/data/browser>. Acesso em: 04 ago. 2017.

ENERGIGAS SVERIGE. Verksamhetsberattelse (Relatório Anual). Energigas Sverige The Swedish Gas Association. Stockholm. 2016.

EPA. Biomass Combined Heat and Power Catalog of Technologies. U. S. Environmental Protection Agency Combined Heat and Power Partnership. 2007.

EPA. Anaerobic digestion and its applications. United States Environmental Protection Agency (EPA). 2015.

EPE. Nota técnica DEA 15/14: Inventário energético de resíduos rurais. Empresa de Pesquisa Energética (EPE). Rio de Janeiro. 2014a.

EPE. Nota técnica DEA 18/14: Inventário energético dos resíduos sólidos urbanos. Empresa de Pesquisa Energética. Rio de Janeiro. 2014b.

EPE. Nota técnica DEA 19/14: Inserção da geração fotovoltaica distribuída no Brasil condicionantes e impactos. Empresa de Pesquisa Energética (EPE). Rio de Janeiro. 2014c.

EPE. Plano decenal de expansão da malha de transporte dutoviário - PEMAT 2022. Empresa de Pesquisa Energética (EPE). Rio de Janeiro. 2014d.

EPE. Plano Decenal de Expansão de Energia 2024. Empresa de Pesquisa Energética (EPE). Rio de Janeiro. 2015a.

EPE. Nota técnica DEA 01/15: Estimativa da capacidade instalada de geração distribuída no SIN: Aplicações no horário de ponta. Empresa de Pesquisa Energética (EPE). Rio de Janeiro. 2015b. 
EPE. Balanço Energético Nacional 2016: Ano base 2015. Empresa de Pesquisa Energética (EPE). Rio de Janeiro. 2016a.

EPE. O compromisso do Brasil no combate às mudanças climáticas: Produção e uso de energia. Empresa de Pesquisa Energética (EPE). Rio de Janeiro. 2016 b.

EPE. Infraestrutura de gasodutos de transporte no Brasil - atualizado em 30/06/2016. Empresa de Pesquisa Energética (EPE), 2016c. Disponível em: <http://www.epe.gov.br/Petroleo/Documents/MAPA\%20G\%C3\%A1s\%20Natural_EPE\%202 015.pdf $>$. Acesso em: 22 jun. 2017.

EPE. Panorama da Indústria de Gás Natural na Bolívia. Empresa de Pesquisa Energética (EPE). Rio de Janeiro. 2017.

EUROBSERV'ER. Biogas Barometer. EurObserv'ER. 2014.

EUROPEAN COMMISSION. An energy policy for Europe - Communication from the Commission to the European Council and the European Parliament. European Commission. Brussels. 2007.

EUROPEAN UNION. Energy infrastructure: priorities for 2020 and beyond - a blueprint for an integrated european energy network. Publications Office of the European Union. Luxembourg. 2011.

FIGUEIREDO, N. J. V. Utilização de biogás de aterro sanitário para geração de energia elétrica - Estudo de caso. Dissertação de Mestrado do Programa de Pós-Graduação em Energia da Universidade de São Paulo. São Paulo. 2011.

FINDEISEN, C. Biogas - Trends on the German and international markets. Apresentação no III Fórum do Biogás. 2016.

FNR. Biogas: an introduction. Fachagentur Nachwachsende Rohstoffe e.V. (FNR) - Agency for Renewable Resources. Gulzow, Germany. 2013.

FNR. Bioenergy in Germany: facts and figures 2016. Fachagentur Nachwachsende Rohstoffe e. V. (FNR) - Agency for Renewable Resources. Gulzow, Germany. 2017.

FRONDEL, M. et al. Economic impacts from the promotion of renewable energy technologies: The German experience. Energy Policy, v. 38, p. 4048-4056, 2010.

GASBRASILIANO. Release: GasBrasiliano distribuirá gás natural renovável. GasBrasiliano, 2015. Disponível em: <http://www.gasbrasiliano.com.br/noticias/releases/gasbrasilianodistribuira-gas-natural-renovavel/>. Acesso em: 02 ago. 2017.

GEHRING, CARLOS GUSTAVO. Análise da geração de energia elétrica a partir do biogás produzido na fermentação anaeróbica de vinhaça. Monografia (Graduação em Engenharia Elétrica com ênfase em Sistemas de Energia e Automação) - Escola de Engenharia de São Carlos da Universidade de São Paulo. São Carlos. 2014.

GOLDEMBERG, J.; COELHO, S. T. Renewable energy - traditional biomass vs. modern biomass. Energy Policy, v. 32, p. 711-714, 2004. 
GOLDEMBERG, J.; LUCON, O. Energia, Meio Ambiente \& Desenvolvimento. $3^{\text {a }}$ ed. rev. e ampl. 2. reimpr. ed. São Paulo: Editora da Universidade de São Paulo, 2012.

GOULDING, D.; POWER, N. Which is the preferable biogas utilisation technology for anaerobic digestion of agricultural crops in Ireland: Biogas to CHP or biomethane as a transport fuel? Renewable Energy, v. 53, p. 121-131, 2013.

GROSS, R. et al. On picking winners: The need for targeted support for renewable energy. Centre for Energy Policy and Technology, Imperial College London. London. 2012.

HAHN, H. et al. Review of concepts for a demand-driven biogas supply for flexible power generation. Renewable and Sustainable Energy Reviews, v. 29, p. 383-393, 2014.

HAKE, J. F. et al. The German Energiewende - History and status quo. Energy, v. 92, p. 532$546,2015$.

HELM, D. Energy policy should let the market pick the winners. Financial Times, London, Outubro 2014.

HIJAZI, O. et al. Review of life cycle assessment for biogas production in Europe. Renewable and Sustainable Energy Reviews, v. 54, p. 1291-1300, 2016.

HULTMAN, N. E. et al. Factors in low-carbon energy transformations: Comparing nuclear and bioenergy in Brazil, Sweden, and the United States. Energy Policy, v. 40, p. 131-146, 2012.

IEA. Wind Energy: Technology Roadmap. International Energy Agency (IEA). Paris. 2013.

IEA. Key World Energy Statistics. International Energy Agency (IEA). Paris. 2016.

IEA BIOENERGY. Bioenergy - A sustainable and reliable energy source. International Energy Agency (IEA) Bioenergy. [S.1.]. 2009.

IEA BIOENERGY. Country Reports Summary 2014. International Energy Agency (IEA) Bioenergy. 2015a.

IEA BIOENERGY. Germany Country Report 2015. International Energy Agency (IEA) Bioenergy Task 37. 2015 b.

IEA BIOENERGY. Upgrading plant list 2015. International Energy Agency (IEA) Bioenergy Task 37, 2015c. Disponível em: <http://www.iea-biogas.net/plant-list.html>. Acesso em: 15 jul. 2016.

IEA BIOENERGY. Country Reports Summary 2015. International Energy Agency (IEA) Bioenergy Task 37. 2016.

IEE. Apresentação do Programa de Pós-Graduação em Energia. Instituto de Energia e Ambiente da Universidade de São Paulo, 2016. Disponível em: <http://www.iee.usp.br/pos/?q=ppge/apresentação>. Acesso em: 10 ago. 2017.

IPCC. Anthropogenic and Natural Radiative Forcing. In: CHANGE, I. P. O. C. Climate Change 2013: The Physical Science Basis. Contribution of Working Group I to the Fifth 
Assessment Report of the Intergovernmental Panel on Climate Change. Cambridge, United Kingdom and New York, NY, USA: Cambridge University Press, 2013.

IPCC. Climate Change 2014: Synthesis Report. Contribution of Working Groups I, II and III to the Fifth Assessment Report of the Intergovernmental Panel on Climate Change [Core Writing Team, R.K. Pachauri and L.A. Meyer (eds.)]. Geneva, p. 151, 2014.

IRENA. Biogas for road vehicles: Technology brief. International Renewable Energy Agency (IRENA). Abu Dhabi, 2017.

JARDIM, M. A. C. Valorização Económica do Biogás: Geração Elétrica vs. Produção de Biometano para Injeção na Rede. Setúbal: Dissertação (Mestrado em Engenharia de Produção) - Instituto Politécnico de Setúbal, 2013.

KABERGER, T. History of nuclear power in Sweden. Estudos Avançados, v. 21, p. 225-242, 2007.

KADAM, R.; PANWAR, N. L. Recent advancenment in biogas enrichment and its applications. Renewable and Sustainable Energy Reviews, v. 73, p. 892-903, 2017.

KANELLAKIS, M.; MARTINOPOULOS, G.; ZACHARIADIS, T. European energy policy A review. Energy Policy, v. 62, p. 1020-1030, 2013.

KENNEDY, C. Climate Change: Atmospheric Carbon Dioxide. National Oceanic and Atmospheric Administration (NOAA), 2016. Disponível em: $<$ https://www.climate.gov/news-features/understanding-climate/climate-change-atmosphericcarbon-dioxide>. Acesso em: 02 jun. 2017.

KLEIN, N. This changes everything: capitalism vs. the climate. New York: Simon \& Schuster, 2014.

LAMBERT, M. Biogas: A significant contribution to decarbonising gas markets? The Oxford Institute for Energy Studies - University of Oxford. Oxford. 2017.

LARSSON, M.; GRONKVIST, S.; ALVFORS, P. Upgraded biogas for transport in Sweden effects of policy instruments on production, infrastructure deployment and vehicle sales. Journal of Cleaner Production, v. 112, p. 3774-3784, 2016.

LEME, R. M.; SEABRA, J. E. A. Technical-economic assessment of different biogas upgrading routes from vinasse anaerobic digestion in the Brazilian bioethanol industry. Energy, v. 119, p. 754-766, 2017.

LINO, F. A. M.; ISMAIL, K. A. R. Energy and environmental potential of solid waste in Brazil. Energy Policy, v. 39, p. 3496-3502, 2011.

LOBATO, L. C. D. S. Aproveitamento energético do biogás gerado em reatores UASB tratando esgoto doméstico. Tese de Doutorado da Escola de Engenharia da Universidade Federal de Minas Gerais. Belo Horizonte. 2011.

MANKIW, N. G. Introdução à economia. Tradução da $6^{a}$ edição norte-americana. ed. São Paulo: Cengage Learning, 2016. 
MARKARD, J.; WIRTH, S.; TRUFFER, B. Institutional dynamics and technology legitimacy - A framework and a case study on biogas technology. Research Policy, v. 45, p. 330-344, 2016.

MATSUI, T.; IMAMURA, S. Removal of siloxane from digestion gas of sewage sludge. Bioresource Technology, n. 101, p. 529-532, 2010.

MILLS, N.; PEARCE, P.; THORPE, R. Should I generate electricity or bio-methane from my biogas? 18th European Biosolids \& Organic Resources Conference and Exhibition, n. Disponível em:. Acesso em: 13 mar. 2017., 2013.

MILNE, R. Boost to nuclear energy as Sweden agrees to build more reactors. Financial Times, 2016. Disponível em: <https://www.ft.com/content/b44e3214-2f13-11e6-bf8d26294ad519fc >. Acesso em: 05 mai. 2017.

MIRANDA, M. M. D. Fator de emissão de gases de efeito estufa da geração de energia elétrica no Brasil: implicações da aplicação da Avaliação do Ciclo de Vida. Dissertação de Mestrado em Ciências da Engenharia Ambiental da Escola de Engenharia de São Carlos da Universidade de São Paulo. São Carlos. 2012.

MME. Boletim mensal de acompanhamento da indústria de gás natural. Edição no 118. Ministério de MInas e Energia (MME) - Secretaria de Petróleo, Gás Natural e Combustíveis Renováveis - Departamento de Gás Natural. [S.1.]. 2016.

MOREY, M.; KIRSCH, L. Germany's Renewable Energy Experiment: A Made-to-Order Catastrophe. The Electricity Journal, v. 27, p. 6-20, 2014.

MORRIS, C.; PEHNT, M. Energy Transition: The German Energiewende. Berlin, Germany: Heinrich Boll Stiftung, 2016.

MOURA, A. C. M. Novas tendências do consumo de GLP - Gás Liquefeito de Petróleo no Brasil. Monografia - MBA em Engenharia e Negócios de Gás e Petróleo. Centro Universitário do Instituto Mauá de Tecnologia. São Caetano do Sul. 2012.

MULLER-MONTEIRO, E. Teoria de grupos de pressão e uso político do setor elétrico brasileiro. São Paulo: Dissertação de Mestrado - Programa Interunidades de Pós-Graduação em Energia da Universidade de São Paulo, 2007.

MURPHY, J. D.; MCKEOGH, E.; KIELY, G. Technical/economic/environmental analysis of biogas utilisation. Applied Energy, v. 77, p. 407-427, 2004.

NASA. NASA, NOAA Data Show 2016 Warmest Year on Record Globally. Release 17-006, 2017. Disponível em: <https://www.nasa.gov/press-release/nasa-noaa-data-show-2016warmest-year-on-record-globally>. Acesso em: 02 jun. 2017.

NIVOLA, P.; CARTER, E. Making Sense of "Energy Independence". In: PASCUAL, C.; ELKIND, J. Energy Security: Economics, Politics, Strategies and Implications. Washington, DC: The Brookings Institution, 2010. 
NREL. Biogas potential in the United States. National Renewable Energy Laboratory (NREL). Golden, CO. 2013.

OLIVEIRA, P. A. V. D.; HIGARASHI, M. M. Geração e utilização de biogás em unidades de produção de suínos. Embrapa Suínos e Aves. Concórdia. 2006.

OLSSON, L.; FALLDE, M. Waste(d) potential: a socio-technical analysis of biogas production and use in Sweden. Journal of Cleaner Production, v. 98, p. 107-115, 2015.

ONS. Dados relevantes 2015. Operador Nacional do Sistema Elétrico (ONS), 2016. Disponível

em:

<http://www.ons.org.br/download/biblioteca_virtual/publicacoes/DADOS_2015/html/index.h tml>. Acesso em: 22 jun. 2017.

PATRIZIO, P. et al. Biomethane as a transport fuel - A comparison with other biogas utilization pathways in northern Italy. Applied Energy, v. 157, p. 25-34, 2015.

PATTERSON, T. et al. An evaluation of the policy and techno-economic factors affecting the potential for biogas upgrading for transport fuel use in the UK. Energy Policy, n. 39, p. 18061816, 2011.

PAVAN, M. D. C. O. Geração de energia a partir de resíduos sólidos urbanos: avaliação e diretrizes para tecnologias potencialmente aplicáveis no Brasil. Tese de Doutorado Programa de Pós-Graduação em Energia (EP / FEA / IEE / IF) da Universidade de São Paulo. São Paulo. 2010.

PAVANI, R. H. Análise das vantagens e desvantagens no uso do gás natural em veículos de passeio. Monografia do curso de Pós Graduação em Engenharia Automotiva da Escola de Engenharia de Mauá. São Caetano do Sul. 2012.

PECORA, V. Implementação de uma unidade demonstrativa de geração de energia elétrica a partir do biogás de tratamento do esgoto residencial da USP: estudo de caso. Dissertação de Mestrado do Programa Interunidades de Pós-Graduação em Energia da Universidade de São Paulo. São Paulo. 2006.

PEGELS, A.; LUTKENHORST, W. Is Germany's energy transition a case of successful green industrial policy? Contrasting wind and solar PV. Energy Policy, v. 74, p. 522-534, 2014.

PEREIRA JR., A. O. et al. Perspectives for the expansion of new renewable energy sources in Brazil. Renewable and Sustainable Energy Reviews, v. 23, p. 49-59, 2013.

PERRY, R. H.; CHILTON, C. H. Manual de engenharia química. $5^{\text {a }}$. ed. Rio de Janeiro: Guanabara Dois, 1986.

PERSSON, T. et al. A perspective on the potential role of biogas in smart energy grids. International Energy Agency (IEA) Bioenergy. 2014.

PETROBRAS. Refinaria gera energia com biogás do Aterro de Gramacho. Petrobras: Blog Fatos e Dados, 2014. Disponível em: <http://www.petrobras.com.br/fatos-e-dados/refinariagera-energia-com-biogas-do-aterro-de-gramacho.htm>. Acesso em: 02 jul. 2017. 
PETTERSON, A.; WELLINGER, A. Biogas Upgrading Technologies - developments and innovations. International Energy Agency - Bioenergy - Task 37. 2009.

PFUnD, N.; HEALEY, B. What Would Jefferson Do? The Historical Role of Federal Subsidies in Shaping America's Energy Future. DBL Investors. 2011. Disponível em : <http://www.dblpartners.vc/resource/what-would-jefferson-do/>. Acesso em: 04 ago. 2017

PINTO JR. et al. Economia da energia: fundamentos econômicos, evolução história e organização industrial. Rio de Janeiro: Elsevier, 2007.

POVEDA, M. M. R. Análise econômica e ambiental do processamento da vinhaça com aproveitamento energético. Dissertação de mestrado do Programa de Pós-Graduação em Energia do Instituto de Energia e Ambiente da Universidade de São Paulo. São Paulo. 2014.

PROBIOGÁS. Guia Prático do Biogás - Geração e Utilização. 2010.

PROBIOGÁS. Catálogo de tecnologias e empresas de biogás. Probiogás, Ministério das Cidades, Deustsche Gesellschaft fur Internationale Zusammenarbelt GmbH (GIZ). Brasília, DF. 2015a.

PROBIOGÁS. Tecnologias de digestão anaeróbia com relevância para o Brasil: substratos, digestores e uso de biogás. Probiogás; organizadores, Ministério das Cidades, Deutsche Gesellschaft fur Internationale Zusammenarbeit GmbH (GIZ). Brasília, DF. 2015b.

PROBIOGÁS. Barreiras e propostas de soluções para o mercado de biogás no Brasil. Probiogás, Ministério das Cidades, Deutsche Gesellschaft fur Internationale Zusammenarbelt GmbH (GIZ). Brasília, DF. 2016a.

PROBIOGÁS. Biometano como combustível veicular. Probiogás; Ministério das Cidades, Deutsche Gesellschaft fur Internationale Zusammenarbelt GmbH (GIZ). Brasília, DF. 2016b.

REN 21. Renewables 2017 Global Status Report. REN 21 Secretariat. Paris. 2017.

RENEWABLE ENERGIES AGENCY. Facts: The most important data on renewable energy in Germany. Clear and concise. Agentur fur Erneuerbare Energien (Renewable Energies Agency), 2015. Disponível em: <https://www.unendlich-vielenergie.de/media/file/412.AEE_Talking_Cards_2015_engl_final.pdf $>$. Acesso em: 09 jun. 2017.

RIBEIRO, C. M. Análise energética, econômica e ambiental da biodigestão de resíduos agropecuários gerados por pequenos e médios produtores rurais da região sul do Espírito Santo. Tese (Doutorado) - Programa de Pós-Graduação em Energia, Universidade de São Paulo, São Paulo, 2013.

ROMEIRO, D. L. As indefinições da indústria do gás no Brasil. Grupo de Economia da Energia - Blog Infopetro, 2016. Disponível em: <https://infopetro.wordpress.com/2016/10/26/as-indefinicoes-da-industria-do-gas-no-brasil/>. Acesso em: 05 ago. 2017. 
ROSENTIEL, D. P. V.; HEUERMANN, D. F.; HUSIG, S. Why has the introduction of natural gas vehicles failed in Germany? Lesson on the role of market failure in markets for alternative fuel vehicles. Energy Policy, v. 78, p. 91-101, 2015.

SALOMON, K. R. Avaliação técnico-econômica e ambiental da utilização do biogás proveniente da biodigestão da vinhaça em tecnologias para geração de eletricidade. Itajubá, MG: Tese (Doutorado) - Universidade Federal de Itajubá, Itajubá, 2007.

SANCHES-PEREIRA, A. et al. Is natural gas a backup fuel against shortages of biogas or a threat to the Swedish vision of pursuing a vehicle fleet independent of fossil fuels? Renewable Energy, v. 83, p. 1187-1199, 2015.

SANTO FILHO, F. D. E. Estimativa do aproveitamento energético do biogás gerado por resíduos sólidos urbanos no Brasil. Dissertação (Mestrado) - Programa de Pós-Graduação em Energia) - EP / FEA / IEE / IF da Universidade de São Paulo, São Paulo, 2013.

SANTOS, I. F. S. D.; BARROS, R. M.; TIAGO FILHO, G. L. Electricity generation from biogas of anaerobic wastewater treatment plants in Brazil: an assessment of feasibility and potential. Journal of Cleaner Production, v. 126, p. 504-514, 2016.

SCOPE. Bioenergy \& Sustainability: bridging the gaps. Scientific Committee on Problems of the Environment (SCOPE). São Paulo. 2015.

SECRETARIA DE ENERGIA E MINERAÇÃO. São Paulo instala o Comitê Gestor do Programa Paulista de Biogás. Secretaria de Energia e Mineração do Governo do Estado de São Paulo, 2017. Disponível em: <http://www.energia.sp.gov.br/2017/03/sao-paulo-instala-ocomite-gestor-do-programa-paulista-de-biogas/>. Acesso em: 02 ago. 2017.

SEE. Plano Paulista de Energia/2020. Secretaria de Energia do Estado de São Paulo. São Paulo. 2012.

SENAI. Oportunidades da cadeia produtiva de biogás para o estado do Paraná. Serviço Nacional de Aprendizagem Industrial (SENAI) - Paraná. Curitiba. 2016.

SENSFU $\beta$, F.; RAGWITZ, M.; GENOESE, M. The merit-order effect: A detailed analysis of the price effect of renewable electricity generation on spot market prices in Germany. Energy Policy, v. 36, p. 3086-3094, 2008.

SHEN, Y. et al. An overview of biogas production and utilization at full-scale wastewater treatment plants (WWTPs) in the United States: Challenges and opportunities towards energyneutral WWTPs. RenewableandSustainableEnergyReviews, v. 50, p. 346-362, 2015.

SILVA, R. C. D.; NETO, I. D. M.; SEIFERT, S. S. Electricity supply security and the future role of renewable energy sources in Brazil. Renewable and Sustainable Energy Reviews, v. 59, p. 328-341, 2016.

STEFFY, L. In Energy, 'Picking Winners' Isn't the Problem. Forbes, New York, Junho 2013. 
STRBAC, G. et al. Delivering future-proof energy infrastructure. Report for National Infrastructure Commission; Energy Policy Research Group, University of Cambridge; Imperial College London. 2016.

SUN, Q. et al. Selection of appropriate biogas upgrading technology - a review of biogas cleaning, upgrading and utilisation. Renewable and Sustainable Energy Reviews, n. 51, p. 521-532, 2015.

SVENSSON, F. Public policies to biogas dissemination in Sweden. Energigas Sverige - The Swedish Gas Association. Apresentação no III Fórum do Biogás. 2016.

SVENSSON, M. Country Report Sweden. International Energy Agency (IEA) Bioenergy Task 37. Berlin, Germany. 2015.

THE ECONOMIST. Picking winners, saving losers. The Economist, Paris, Agosto 2010.

THE WHITE HOUSE. Blueprint for a secure energy future. The White House. Washington, DC. 2011.

THE WHITE HOUSE. The all-of-the-above energy strategy as a path to sustainable economic growth. The White House - Executive Office of the President of The United States. Washington, DC. 2014.

THE WHITE HOUSE. Remarks by the President in State of the Union Address. Washington: The White House, 2015. Disponível em: <https://obamawhitehouse.archives.gov/the-pressoffice/2015/01/20/remarks-president-state-union-address-january-20-2015>. Acesso em: 02 jun. 2017.

TOLMASQUIM, M. T. Energia renovável: hidráulica, biomassa, eólica, solar, oceânica. Rio de Janeiro: Empresa de Pesquisa Energética (EPE), 2016a.

TOLMASQUIM, M. T. Energia termelétrica: gás natural, biomassa, carvão, nuclear. Rio de Janeiro: Empresa de Pesquisa Energética (EPE), 2016 b.

UNICA. Moagem de cana-de-açúcar e produção de açúcar e etanol - safra 2015/2016. União da Indústria de Cana-de-Açúcar (UNICA), 2017. Disponível em: <www.unica.com.br/unicadata>. Acesso em: 10 ago. 2017.

UNITED NATIONS. United Nations Framework Convention on Climate Change, 1992. Disponível em: <https://unfccc.int/resource/docs/convkp/conveng.pdf>. Acesso em: 02 jun. 2017.

URBAN, W. Experiences and future perspectives of biomethane in Germany from a regulatory perspective. Ecologic Institute, 2013. Disponível em: <http://ecologic.eu/10137>. Acesso em: 04 ago. 2017.

USDA. Biogas opportunities roadmap - Voluntary actions to reduce methane emissions and increase energy independence. U.S. Department of Agriculture (USDA), U.S. Environmental Protection Agency, U.S. Department of Energy. 2014. 
VALENTE, V. B. Análise de viabilidade econômica e escala mínima de uso do biogás de reatores anaeróbios em Estações de Tratamento de Esgoto no Brasil. Dissertação (Mestrado) - Programa de Planejamento Energético da Universidade Federal do Rio de Janeiro, Rio de Janeiro, 2015.

VALOR. Solvi inaugura térmica a biogás de aterro sanitário. Valor Econômico, 2016. Disponivel em: <http://www.valor.com.br/empresas/4712409/solvi-inaugura-termica-biogasde-aterro-sanitario>. Acesso em: 07 Agosto 2017.

VEIGA, A. P. B. Contribuição à avaliação das barreiras e oportunidades regulatórias, econômicas e tecnológicas do uso de biometano produzido a partir de gás de aterro no Brasil. São Paulo: Dissertação (Mestrado em Ciências) - Programa de Pós-Graduação em Energia - Instituto de Energia e Ambiente, Universidade de São Paulo, 2016.

WHITE, W. et al. The role of governments in renewable energy: The importance of policy consistency. Biomass and Bioenergy, v. 57, p. 97-105, 2013.

WORLD BANK. DataBank. The World Bank, 2017. Disponível em: <http://databank.worldbank.org/data/home.aspx>. Acesso em: 04 ago. 2017.

WU, B. et al. Energetic-environmental-economic assessment of the biogas system with three utilization pathways: Combined heat and power, biomethane and fuel cell. Bioresource Technology, v. 214, p. 722-728, 2016.

YANG, L. et al. Progress and perspectives in converting biogas to transportation fuels. Renewable and Sustainable Energy Reviews, n. 40, p. 1133-1152, 2014.

YERGIN, D. A busca: energia, segurança e a reconstrução do mundo moderno. Rio de Janeiro: Intrínseca, 2014.

ZANETTE, A. L. Potencial de aproveitamento energético do biogás no Brasil. Rio de Janeiro Dissertação (mestrado) - UFRJ/ COPPE/ Programa de Planejamento Energético, 2009.

ZHANG, C. et al. Reviewing the anaerobic digestion of food waste for biogas production. Renewable and Sustainable Energy Reviews, v. 38, p. 383-392, 2014. 